\title{
الجوانب القانونية للوساطة فى التوفيق بين راغبى الزواج
}

\author{
shel \\ د./طارق عبد اللَه محمد أبو حوه \\ مدرس القانون المدنى - جامعت الدلتا - مصر \\ ورئيس قسم القانون بالأكاديميت الأمريكيتتبالكونيت
}




\section{هقدهة}

يُعتبر الزواج من أسمى الروابط الإنسانية التي تجمع بين الرجل والمـرأة ، ويمثل الحدث الأكبر فيمـا بينهمـا ، بالنظر إلى مـا يحدثه من أثر قيـام الوحدة والالتئام ليكون كل منها بمثابة اللباس للآخر ، لذلك فهو سنة من سنن الله في الخلق و التكوين ،

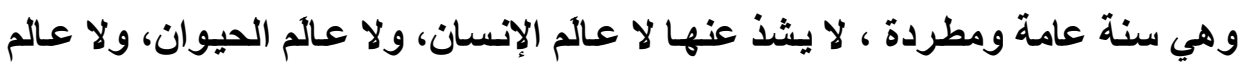
النبات.

وبالنظر إلى الإحصائيات التى ترصد معدلات العنوسة ، فإن الأمر يثير المخاوف

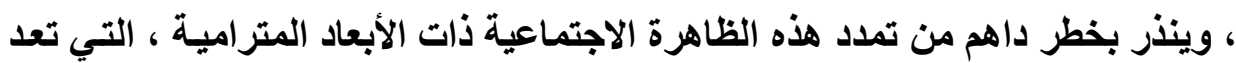
من أمراض المجتمع المزمنـة التي يجب مواجهتها والحـد مـن انتشارها ، وتحجيم آثار ها بالبحث عن الأسباب الاقتصادية والاجتماعية والدينية التي أدت إليها، خاصة وأن الإسـلام يحض على الزواج، وينهى عن الرهبنـة والتبتّل، ويشجع على العفـف الته وتكوين الأسر القوية ، التي تعد اللبنات الأولى في بناء المجتمع القوي المتماسك. ومسن هنـا بدأت ظـاهرة الوسـاطة بين راغبى الزواج تحتل مكانساً خصباً لحل إثكاليات العنوسـة الثُفرطة ، وتفرض نفسها بقوة على المجتمعات التى تعانى من تفشى ظاهرة العنوسة ؛ لذلك لا ينكر غير مُجادل ، أن مهنة وسيط النكاح أصبحت من المهن الأساسية في حياة المجتمعات المعاصرة ؛ نتيجة التطور الذي طرأ على العلاقات الاجتماعيـة والاقتصادية ،وبوصفهـا المهنـة التـي تمثل أحسـ الطرق البديلـة لتجـاوز انعكاسـات العنوسـة على المستوين الفردي والجمـاعي ، ولكونها تعمل على تحقيّق

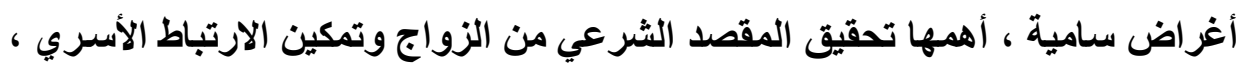


باعتبار هما ركيزة متجذرة لبناء الحضار ات ، ولأنهما الأساس الأرستخ والأمتن للترابط المجتمعي. ولا شك فبان المستوى المهني الذي يتمتع بـه الوسبط لابـ أن يكون ذو تأثير خـاص على إنجـاز عمليـات التوفيق ، فالوسبط البـارع ممن يملكون مهارات الإقـاع والقدرة على انتقاء العبارات الجاذبة والحديث الشيق ، يكون له السبق في تحقيق نتائج باهرة في عملية التوفيق ، ويكاد يبحث جميع الراغبين في الزواج عن هذه الطائفة من الوسطاء المحترفين ، بوصفهم يمثلون بالنسبة إلى العميل الثخص المُفوض بـاحتراف للتعبير عن خصائصهم بمهارة ، والذى يبدع فى إبراز ما يتمتعون به من مزايـا والعمل على إخفاء ما ينتقص من شأنهم في نظر الطرف الأخر .

وتمثل الوساطة مرحلة وسط بين التعارف الثخصى وبين الزواج والخطبة ،

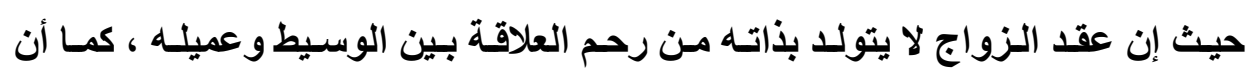
الوساطة لاتؤدى مباشرة إلى إبرام الزواج وإن كانت ثُهيأ لإبرامه كالخطبة ، وغايـة مـا تهذف إليه الوساطة هو خلق حالة من الألفة والتوافق والقبول المبلئى ، بحيث تثرك للطرفين الحريـة الكاملة فى اللدخول إلى علاقة الزواج أو العُزوف عنهـا ، لذا فهى لا تكسب حقوق الطرفين قوة إلزامية لإجبار الطرف الآخر على الالتزام ببإبرام الخطبة أو

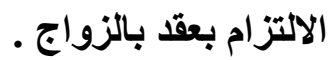

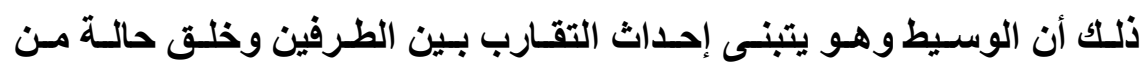
الانسجام بينهما ، فإنه لا يملك السلطة القانونية لإجبار هما على قبول بعضهما البعض ، إنمـا تنحصر مهمته في استقبال الأطراف الراغبـة في الزواج والإنصات إليها ، مـع توسيع قاعدة التعارف فيما بينهما ، وبذل مهاراته المهنية بوصفه وسيطاً محترفاً لحل 
الإشكاليات التي تعترض حصول القبول والارتباط ، لذلك يخرج عن إطار المهمة المنوط بها مسألة تحصيل القبول الحر المستنير للاخول في رابطة الزواج الشرعية ، حيث يتعلق ذلك بمحض مزاج شخصى للعميل يجب ان يؤدى لقناعة كاملة بقبول الطرف الأخر زوجاً محتملاً. ويُلعب وسيط النكاح دوراً فعالاً للتوفيق بين العميل الأى فُوضه فى البحث وبين

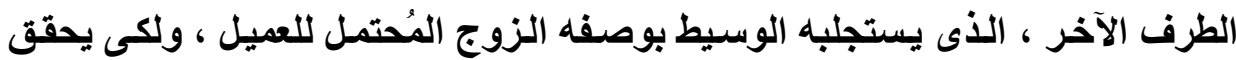
العميل وشريكه الاحتمالي الغاية المستهدفة من الوساطة ، فلابد من أن يكون كل منهمـا على بصيرة بأمر صاحبة ، وأن يارك فيه الخصائص والمزيا التى تؤهلة للقبول ، وأن يتوافقا على المسائل الجوهريـة للزواج ، ولا شـك فبان هذه المتطلبـات تخلق التزامـات عدة في ذمـة الوسبط ، وهذه الالتزامسات لا يمكن إدراكها إلا بممارسـة الوسيط دوراً مهنياً مُحترفاً ، يحقق بمقتضاه حالة من الإنسجام والتوافق بين الطرفين ، ويرفع قدراً مـن الاختلافـات المتوقـع قيامهـا في المستقبل فيمـا بينهــا ، ويكشف عن المخـاطر المحتملـة مـن التوفيق بـين الطرفين ، ويـؤدى ذلــك بـلا جـدال إلى ضـرورة تحديــ المسؤوليات القانونيـة الناجمـة عن هذه الـروابط التى تتوللـ عن عمليـات الوسـاطة

$$
\text { المهنية بين راغبى النكاح. }
$$

فضلاً عن ذلك ، فإن جوهر عمل الوسيط بين راغبي الزواج ، يقوم على أسساس تناقل مجموعـة مـن المعلومـات والبيانـات التى يتــاولها الأطراف فـى مجـال الوسـاطة بحرية كبيرة ، وفي سباق الرغبة المتزايدة لاى الأفراد في التزاوج وتكوين الأسرة ، قد يسعى كل من طرفي العلاقة الراغبة في الارتبـاط ، إلى تحسين الصورة الجسمية لـه

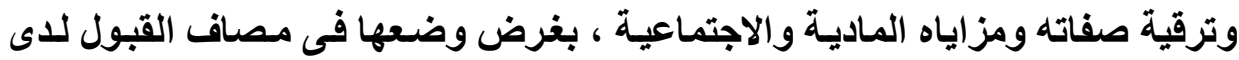
الطرف الآخر ، لذلك يغلب فى هذا النطاق تحديداً السعي إلى إبراز مزايا الطرفين بقدر من المبالغة ، والتي قد يتطور أمرهـا إلى أن تتحول بها العيوب والنقائص الجسمية 
والمعنويـة إلى محاسن ومُحفزات يستجلب بها كل طرف شريكه الآخر ، بل ويجاهد لإقناعه بمحاسنها والتأثير على مزاجه الشخصي بمقتضاها لتحوز رضـائه ، ومـن هنـا تبدو خطورة المحل الذى تنصرف مهنة الوساطة لاحتوائه وتتفيذ منطلباته . لذلك فإن الوساطة بين الراغبين في الزواج ثُنشئ على هذا النحو علاقات بين العميل والوسيط من ناحية ، وبين العميل وشريكه الاحتمسلى مـن ناحية أخرى، هذه الروابط المتعددة لا يمكن تجاهلها بالكليـة ، ولا يجدر بالاعتبـار أن يتم إدراجها في مهي نطاق الوقائع القانونية فحسب ، خاصة مع هيمنة المفاهيم العقدية على البنـاء الواقعي فيها وكيفية التقاء الإرادات المتقابلة لطرفيها ، لذك يكون من غير المقبول تجريدها من أي اعتبار قانوني ، بل يتعين إثبات استقلاليتها كتصرف قانونى متكامل الأركان . لذا تستهدف هذه الدراسة تناول حقيقة مدى خضوع الوسـاطة للمفهوم العقدى ودور سلطان الإرادة فى تكوينها ، مـع بيـان خصائص العقد المبرم بشأنها ، وتحديد التكييف القانونى المناسب لها ، من خلال إجراء مقارنة لبيان أوجه التقارب والاختلاف بين عقد وساطة النكاح الشرعي وغيره من الأنظمـة العقدية المُسماة ، والتي تثميز بوجود أصول مشتركة أو تثـابه ظاهر بينها وبين الوسـاطة التوفيقية للزواج ، وبدافع استجلاء فرصة إخضاع التكييف القانوني لعملية الوسـاطة الزواجية إلى أى من هذه

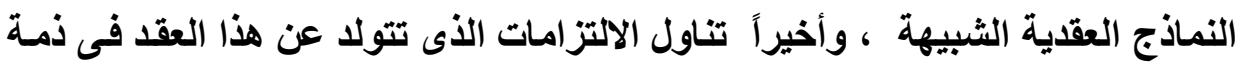
ومن خـلال الطرح السابق الذى يُمهـد لموضـوع البحث ، نـرى أنسه يكون مـن المناسب تناول هذا البحث من خلال الفصلين الآتيين :الفصل الأول : الطبيعة القانونية للعلاقة بين وسيط التوفيق وراغبي الزواج. الفصل الثاني : آثار عقد الوساطة للتوفيق بين راغبى الزواج. 


\section{الفصل الأول}

\section{الطبيعة القانونية للعلاقة بين وسيط التوفيق وراغبي الزواج}

يثور التساؤل عما إذا كان يمكن اعتبار الدور الذي يلعبه وسيط التوفيق في سبيل إبرام عقد الزواج صورة من صور التعبير عن الإرادة التعاقدية بحيث يصلح لبناء

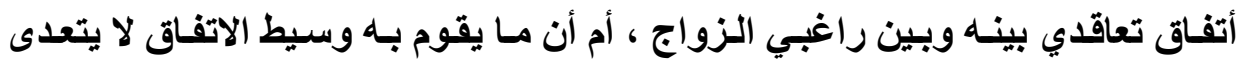
مفهوم الأعمال المادية أو الوقائع القانونية التي لا يتمخض عنها تكويناً عقدياً متكاملاً.

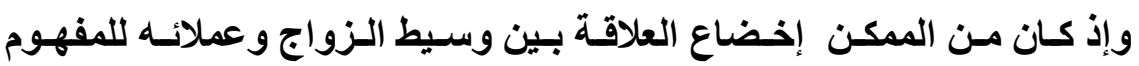

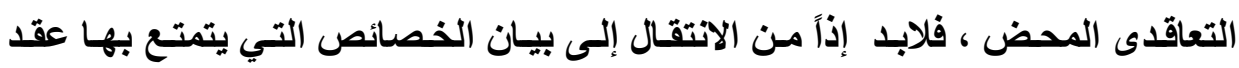

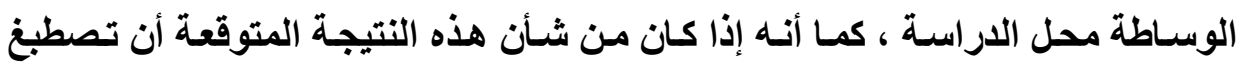
علاقة التوفيق بالمفهوم العقدي ، فإن الأمر يستلزم ولا شكك إنزال التكييف القانوني

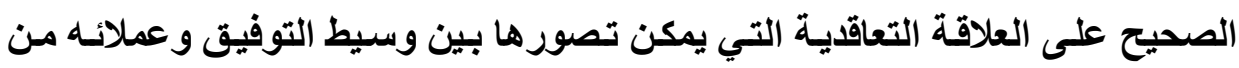
راغبي الزواج ، ممـا يستدعي تقسيم هذا الفصل إلى مبحثين أساسين وعلى النحو

المبحث الأول :- ماهية الوساطة بين راغبى الزواج ومدى خضوعها للمفهوم

$$
\text { العقدي. }
$$

المبحث الثاني :- التكييف القانوني للعلاقة الناشئة بين وسطاء التوفيق وراغبي

$$
\text { الزواج. }
$$




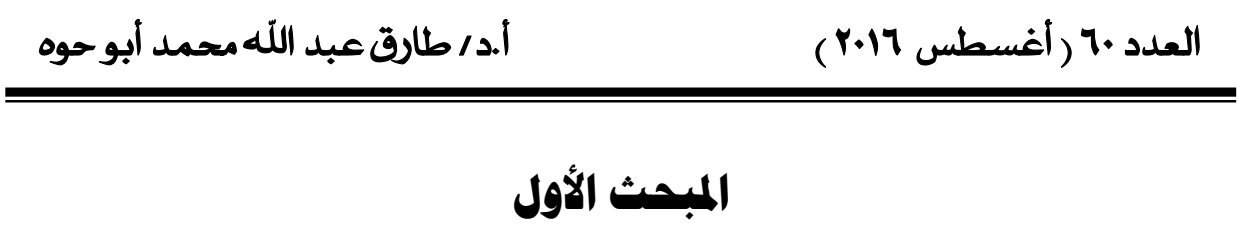

\section{هاهية الوساطة بين راغبى الزواج وهدى خضوعها للهفهوم العقدي}

$$
\text { ينبغى علينا أن نقسم هذا المبحث إلى المطلبين الآتيين :- }
$$

المطب الأول :- ماهية الوساطة بين راغبى الزواج وضو ابطها الثرعية.

المطلب الثنانى :- مدى خضوع وسـاطة التوفيق للمفهوم العقدي وخصائص العقد

المبرم بشأنها.

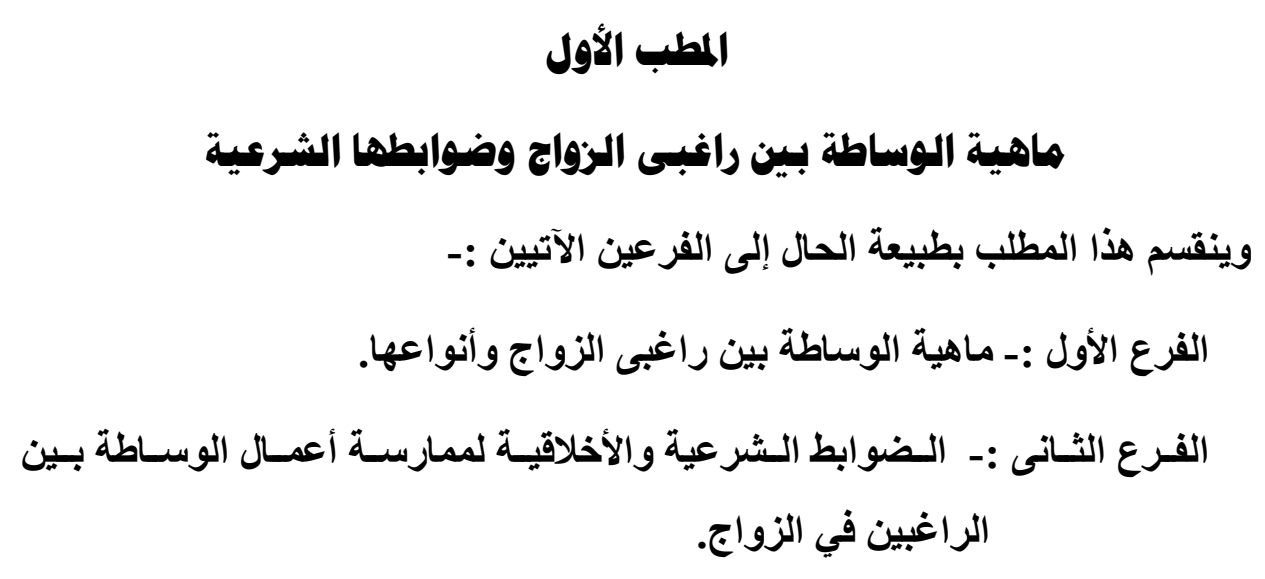




\section{الفرع الأول}

\section{هاهية الوساطة بين راغبى الزواج وأنواعها}

نظراً لعدم تطرق الفقه القانوني لموضوع الوساطة فى الزواج بين الراغبين فيه

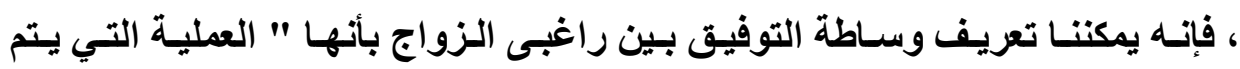
بمقتضاها البحث عن شريك الحياة الزوجية وإيجاده بمواصفات محددة سلفاً ، وذلك من

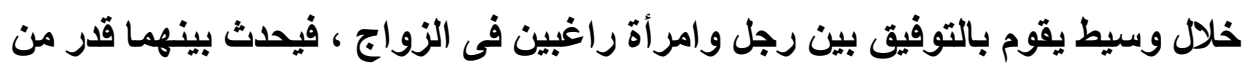

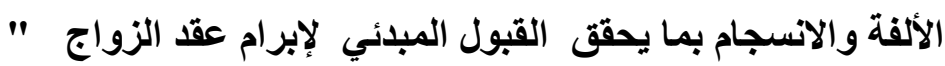
ويتبين من هذا التعريف ، أن مهمة الوسيط الفردي أو المؤسسي ، لا يمكن أن

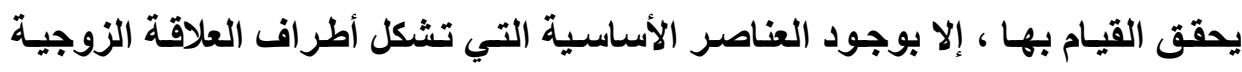

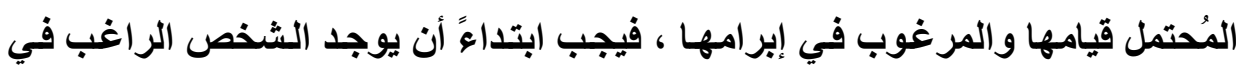

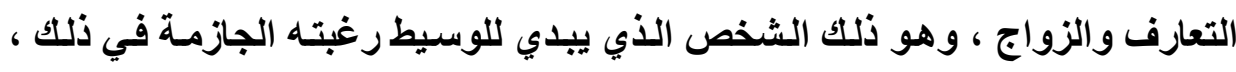

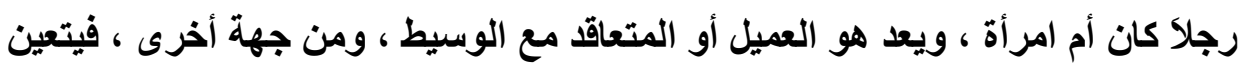

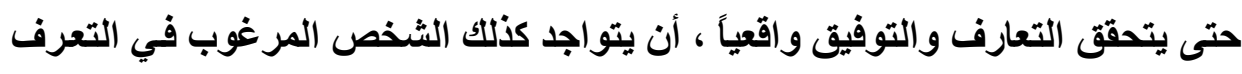

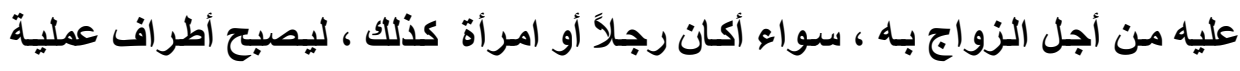

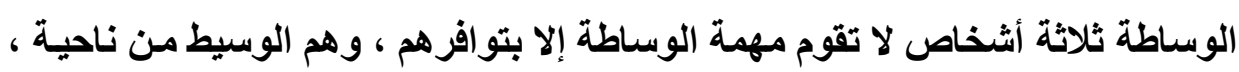

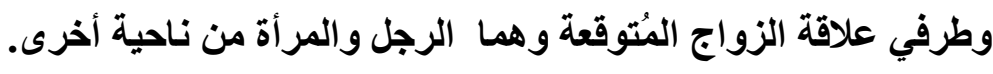

ويعلب وسيط النكاح دوراً فاعلاً فى مواجهة تزايد ظاهرة العنوسة التى تهدد المجتمعات ، وترجع أسباب أنتشار العنوسة في مصر إلى ارتفاع معدلات البطالة

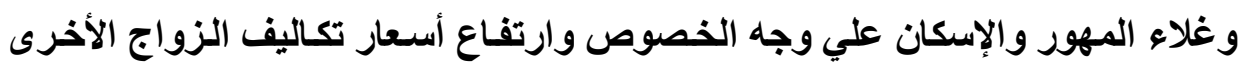


الناتجة عن العادات والتقاليد المتبعة، وكذلك ارتفاع معدل التعليم بالنسبة للإناث وأيضا تباين الكثافة السكانية من حيث الجنس حيث أن عدد الإنـاث أكثر من عدد الرجـال. وجدير بالذكر أن ظاهرة العنوسـة في مصر أدت لزيـادة بعض الظواهر غير المقبولة اجتماعياً ودينياً مثل ظواهر الزواج السري والعرفي بين الشباب في الجامعات والثذوذ الجنسي بـين الفتيـات. وأيضضا العنوسـة للرجـال تعتبر سـبباً في الإقبـال علـي إدمـان المخدرات ، بالإضافة إلي أن المرأة تعاني من متغيرات صحية لها انعكاس سلبى عليها إذا كاتت غير متزوجة فتحدث لها اضطرابات هرمونية ، فضلاً عن أن الفتيات العازبات غالبا ما يتعرضن للإصابة بأمر اض نفسانية مثل الكآبة نظرا لفقدان حياة الأسرة وافتقاد

هـا وقـ يلتجـأ العميل إلسى وسـيط فـردي يمسارس مهـام التوفيتق على سـبيل الاحتراف ولكن بصورة فردية مُستقلة ، وق يتفق العميل مع مؤسسات متخصصة تنظم عملية الوسـاطة بين راغبـي الزواج ، وهي جهات تعني بعملية التوفيق بين الذكور

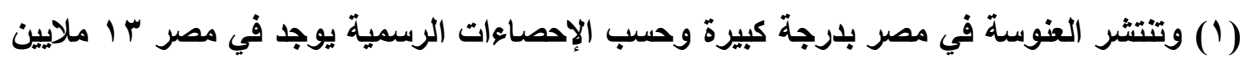

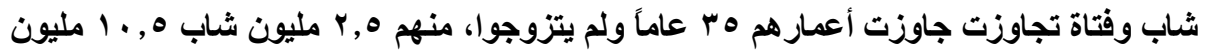

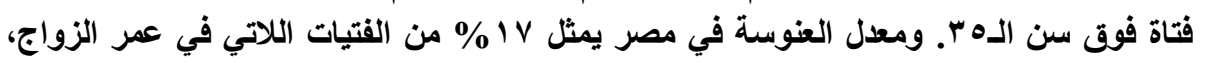

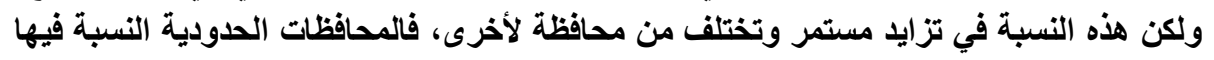

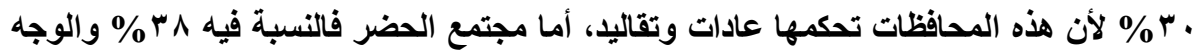

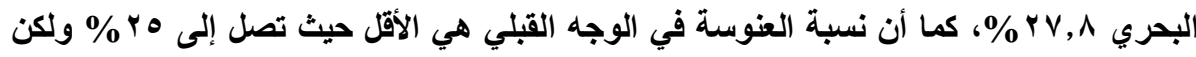

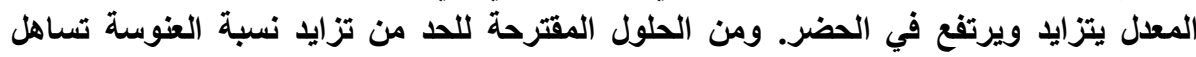

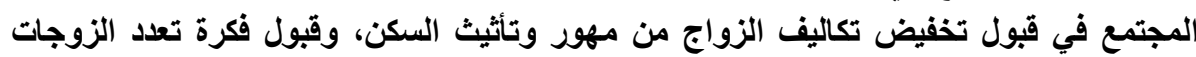

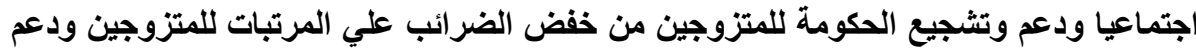

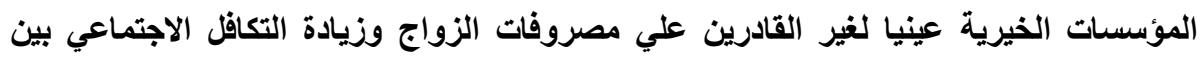

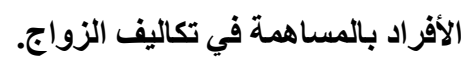

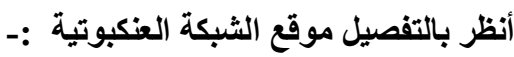

-http://ar.wikipedia.org/wiki . 
والإناث ، وفق تنظيمات معينة وقواعد تحددها خصيصاً لممارسة أعمالها ، وبعضها قد يكون مرخصاً له في ذلك النشاط ، والبعض الآخر يعمل بصورة غير رسمية ، كما يمكن أن يمارس الوسيط نشاطه بصورة واقعية قائمة من خلال المكان والزمسان الذي يحدده لألك ، أو يكون وسيطاً الكترونياً يؤسس لموقع على الشبكة العنكبوتيةة ، حيث يتولى من خلاله عمليات البحث والتوفيق دون أن يلتقى مـع العـلاء مباشرة ، للتلك تقتصر علاقته بهم على التواصل الاجتمـاعى معهم بصورة الكترونيـة ذات أبعاد تفنية ، وهذه الوسيلة قد لا تمكنه من إتمام علمية التوفيق بصورة مهنية احترافية. ومن جاتب آخر ، فقد تكون هذه المؤسسات مُنتميـة إلى فكرة العمل التجاري فتعمل فى صورة شركات خاصة تستهدف الربح ، كما قد يكون إنشاء هذه المؤسسات المتخصصة من قبل بعض منظمات المجتمع المدني وتعمل برعاية رسمية وإثراف عام من قبل جهات الدولة بغرض تقديم خدمة اجتماعية للأفراد ، وأخيراً قد تتولى بعض الحكومات أنشاء هذه المؤسسات خصيصاً كى تقوم بعمل ذو طبيعة اجتماعيـة عامـة لتقدم خدمة لعموم الناس تحت إشراف ورعاية الدولة . وبصفة عامة فقد حلت هذه المؤسسات بشكل كبير محل الأفراد في القيام بدور التعريف والتوفيق بين راغبي الزواج ، وذلك لتقلص دور الأفراد فى الوفاء بمتطلبات الحصول على شريك الحياة الزوجية ، خاصة فى المجتمعات الكبيرة التى يُغلب عليها ضعف روابط التواصل الاجتمـاعي ، حيث توجد هذه المؤسسات بصفة غالبة وتتشط أعمالها الآن في المجتمعات ذات البعد الجغرافي المتسع والتي تثمتع بكثافة سكانية كبيرة ؛ وهو ما يصعب معه على فئات كثيرة من الناس فيها أن يعرف بعضهم البعض بصورة تُسهل عليهم التعارف والزواج ، وغالباً ما تتقاضى هذه المؤسسات أجراً على جهودها في هذا المجال ولو كان أجراً رمزياً ، وذلك لتغطية تكلفة تثغيل النشاط وأجور 
المسوظفين والمستخدمين لــيها. ، وتقـوم هـذه المؤسسـات باسـتقبال الـراغبين مسن الجنسين في الزواج ، وتطلب منهم تسجيل رغباتهم ومواصفاتهم للديها وفق نمساذج مكتوبـة وسبـلات خاصـة ، لتقوم بـدور الوسبط الأمسين في البحث عن شريك الحيـاة المرغوب وفق المواصفات المحددة سلفاً.

وفى الحقيقة فإن الوساطة التى تتبنى هذه الدراسـة تناول جوانبها القانونية ، هى تلكك التى يمارسها الوسيط المُحترف الأى ينتمى لمؤسسة خاصـة أو يعمل لحسابه الفردى الخاص ، وهو الذى يستهدف من ممارسـة الوسـاطة الحصول على أجر مقابل البحث والتحرى ، حيث يبذل مساعى حثيثة ومجهودات ماديـة وفكريـة كبيرة لتحصيل الثخص الأى تتناسب أو تتوافق صفاته مع طموحات العميل فى الارتبـاط الشرعى ، لـذلك يخرج عن إطسار هـا البحث المؤسسـات والمكاتب التابعة مباشـرة للحكومسات وجهات النفع العام ، وتلك التى لا تتقاضسى أجراً مقابل مـا تقدمـه من مساعى وجهود التوسط ، أو تلك التى تعمل بصورة الكترونية كاملة وتتخذ من مواقع الثبكة العنبكويتة محلاً لممارسة جميع أعمالها فى صورة وسيط الكترونى ، بحيث تتجرد عن الالتزامـات الواقعية التى يتسنى للوسيط القيام بها ، كإجراء الحوارات المباشرة مـع العملاء وعقد جلسات شخصية بينهم لإحداث حالة من الألفة و التجانس ، وغير ها من مهام الوساطة المحترفة التى يستحيل على الوسيط الوفاء بها الكترونياً.

ويرجـع تحديـ مجـال الاراسـة على هذا النحو ، إلى أن المؤسسـات ذات النفع العام ، أوتلك التى تعمل مجاناً فى هذا الشأن ، أو التى تنشأ موقعاً الكترونيـاً لممارسـة

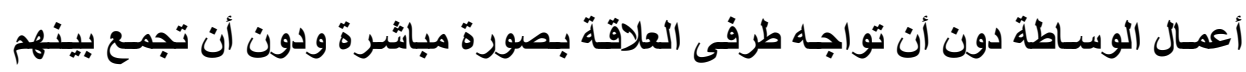


بطريقة شخصية فى أمساكن ماديـة وواقعية تُخصص لجلسات الحوار والتوفيق ( () ، فجميع الصور السـابقة لا تتـدرج ضـمن أعمـال المؤسسسات والأفراد الذين يخضعون للبحث الحسالى ؛ وذلك لأن الوسيط في هذه الصور لا يبذل جهوداً مضنية فى سبيل البحث والتوفيق المحترف ، وإنمـا يترك الأفراد يمارسون عملية التوفيق فيما بيـهن دون أى تلدخل فعـال منـه ، وقد أصبح دور هذه المؤسسـات محدوداً في جميع مراحل التوفيتق التـى يمارسـها الوسطاء المحترفون ، لأنها تحصر نطـات تـخلها فيــا بـين العملاء على تلقى بياناتهم الشخصية ثم تترك لهم المجال مفتوحاً للقيام منفردين بعملية التوفيق ، فضلاً عن أنها لا تولى عملية البحث مشقة الاستكشاف والتحري اللازمين ، كما أنها لا تعنى بتحقيق رغبـات العمـلاء من حيث السعى وراء إيجـاد عمـلاء مقابلين ذوى صفات وخصائص يرغبها طالبى الارتبـاط ويعولون عليها بجديـة فى إبرام عقد الزواج ، وأخيراً تعول بعض هذه الصور ـ كمـا ذكرنـا ـ على المضمون الالكترونـي للتوفيق ، كوسيط النكاح الاكترونى الأى يقوم بالتوسط عن بعد بين العملاء بواسطة

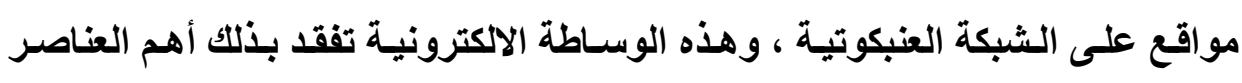
الواقعية التى يجب أن يمارس الوسيط التزاماته المهنية خلالها ، وهى إجراء مواجهات

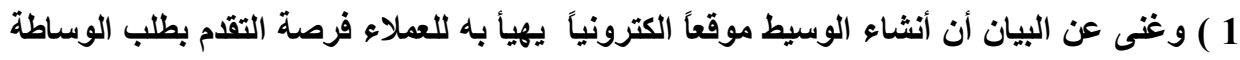

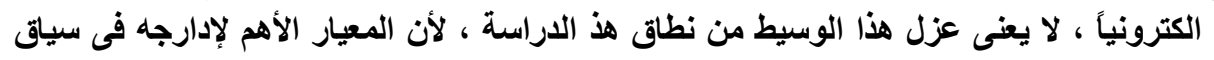

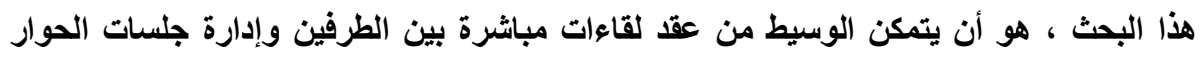

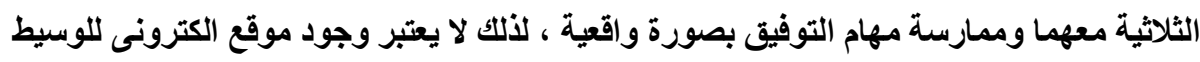

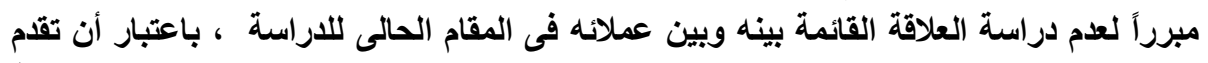

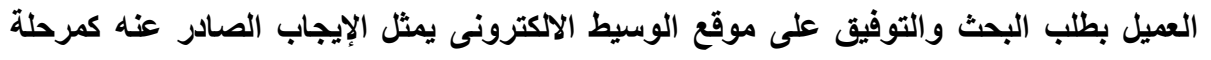

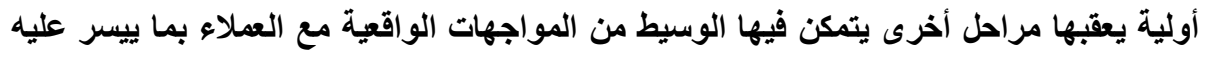
الوفاء بجميع التزاماته من البحث والتوفئ فرئ. 
مادية مباشرة بين العمـلاء على نحو يبصر فيـه بعضهم البعض فى حضور الوسبط ويتجاذبون أطراف الحديث والتفاوض بغرض تحقى الانسجام والقبول .

ومن ثم فهذه الصور السابقة برمتها ، والتى لا تشملها الدراسـة الحاليـة ، لا تحقق لمن يلجأ إليها النتائج المرجوة لهم من خلال ممارسـة مهنية مُحترفة ومُنتجـة ؛ باعتبـار أن عنصر الأجر والاحتراف والتمكن مـن إتمـام التوفيق ، تعُد مـن العناصر الأساسية لتناول وساطة النكاح من خلال دراسة الاتفاقات الناشئة عنها وتحديد طبيعتها القانونية وعما إذا كانت تصطبغ بالصبغة العقدية من عدمـه مـع دراسـة الآثار الناجمـة عن ذلك ، حيث إن طبيعة عمل المؤسسات غير المحترفة فضلاً عن عدم تلقيها لعنصر الأجر مقابـل الوسـاطة ، يـؤدى إلى نقل طبيعة أعمالهـا مـن طور العلاقـات التعاقديـة التبادلية بما تمخضه من أحكام والتزامات تستحق الاراسة والتأصيل إلى طور الأعمـال

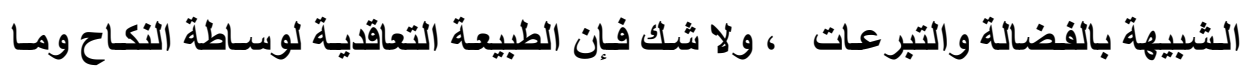
يرافقها من تــاول المركز القانونى للوسيط المهنى المحترف ؛ هـى التى تعطى لهذه الاراسة أهمية عملية وعلمية بالغة وتجعل منها دراسـة خصبة تغطى جاتباً حيويـاً من الممارسـات العمليـة للوسـاطة الحرفيـة الهادفـة للقضاء على انعكاسـات العنوسـة على لـى

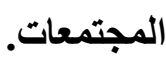

\section{الفرع الثانى}

\section{الضوابط الشرعية والأخلاقية لمهاريسة أعمال الوساطة بين الراغبين في الزواج}

فلئن كانت الوساطة بين راغبي الزواج تعمل في نطاق العلاقة بين رجل وامرأة؛

لذا يجب أن يتم ممارستها في ظلال من الاحتيـاط الخلقي والشرعي ، إذ الأمر يتسم بالحسـاسية والخطـورة ، إذا مـا تجــاوزت أعمــال الوسـيط نطـاق الحــود الأخلاقيـة 
و الضو ابط الدينية ، سواء أكان هذا التجاوز منصرفاً إلى المساس بالقو اعد والأصول

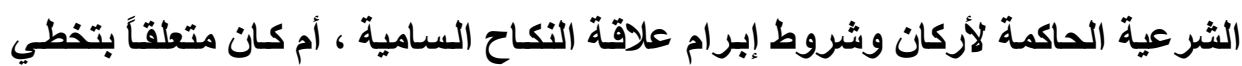

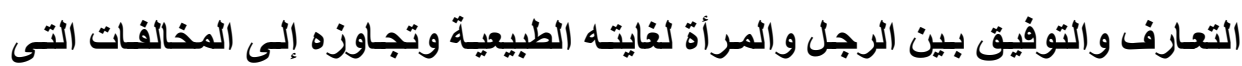
يحظر ها الثرع والقانون.

لـللك ينبغي أن ثُحساط عمليـة الوسـاطة والتوفيـق بـين الراغبين في الززواج بالضو ابط الثرعية والقانونية الآتية :

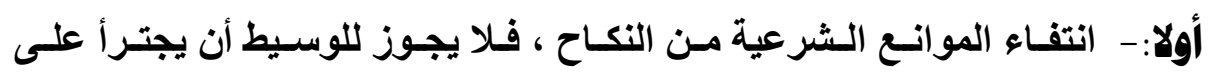

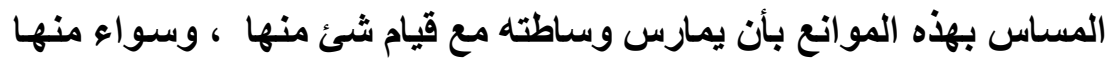
الموانع المؤبدة أو المؤقتة ، ولذلك يحظر على الوسيط أن يمارس أعمال

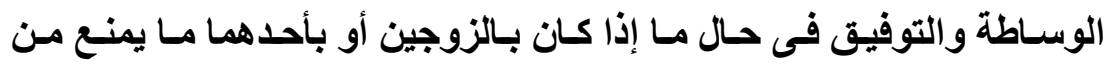
التزويج من محرميه بسبب نسب أو رضـاع أو مصاهرة ، أو كون المرأة

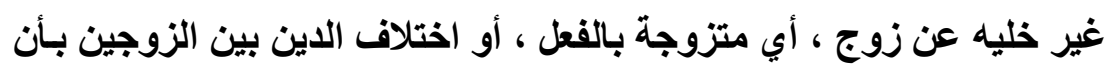

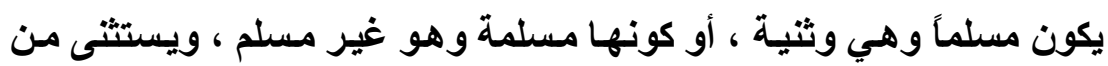
الاختلاف في الاين جواز زواج المسلم بالكتابية بشرط أن تكون عفيفة ، أو

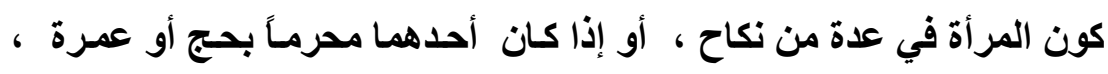

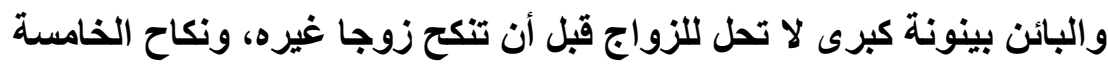

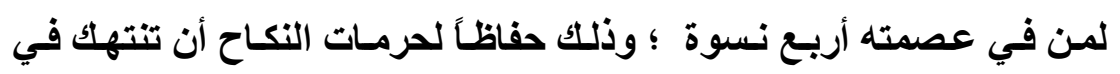

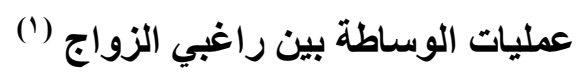

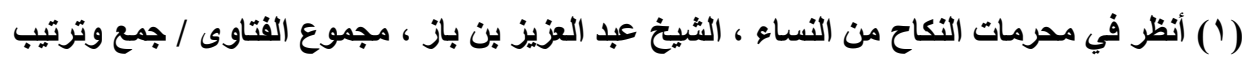

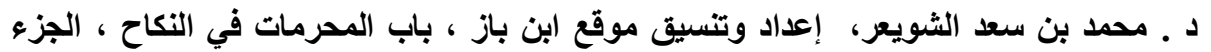
الواحد والعشرون ، ص V ، و وما بعدها . 
ثانيـاً :- يجب ألا تمـارس مهام التوفيق إلا بتوافر الجديـة الكاملة في الدخول إلى علاقة زواج شرعية (1) ، حيث تثطلب عمليسات الوسـاطة والتوفيق الإفصاح عن كثيـر مسن الأسـرار الثخصية والعائليـة ويـضطر خلالهـا الطرفين إلى التخلص من بعض الحقوق اللصيقة بالحريـة ، لذلك ينبغي أن ينتم التعريف والتعارف بين العملاء في ظلال من الرغبة الحقيقية في الزواج ، والإصرار على عقد العزم لإبرامسه ؛ حتـى لا يترتب عليـه الإطـلاع على مـا لا يبـاح الإفضاء به إلا سبب شرعي ، وكي لا تنتهك الأسرار وتكشف العورات بغير

$$
\text { مسوغ مقبول. }
$$

ثالثاً :- ينبغي عدم الإفراط في تعيين الأوصاف والخصائص المتعلقة بالعميل ، لأن التوسط يكون دائمساً بين طرفين لا تربطهمـا علاقة شرعية ، لـلكت لا يجوز شرعاً الإفصاح عن الأوصـاف الخلقية للصورة والجسم بصورة تكشف عن

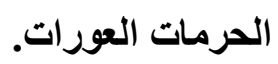

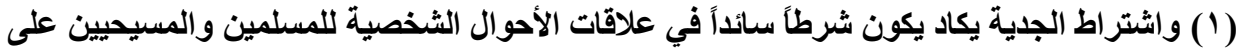

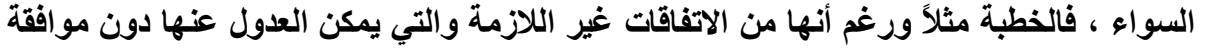

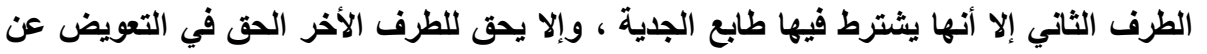

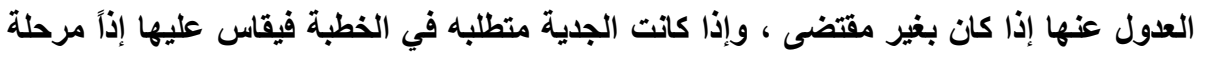

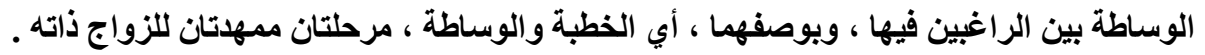

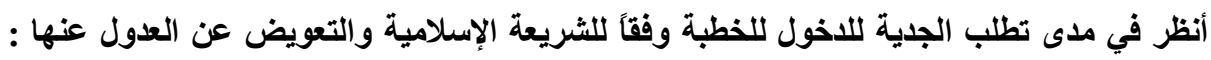

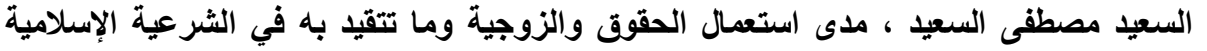

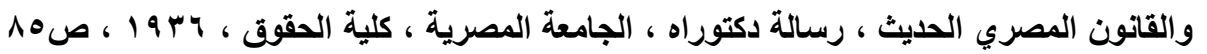

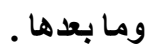

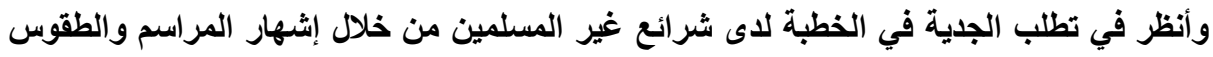

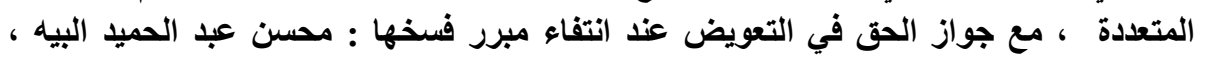

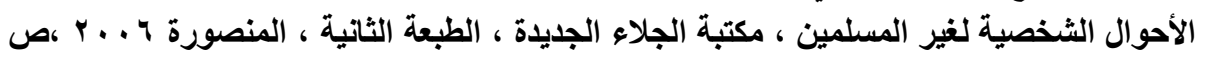


وكنتيجة طبيعية لذلك ، يحظر على الوسبط إبراز الخصائص الجسمية الخفية للعميل ، فعليه واجب نقل المعلومات التي تتعلق بما تنطوى عليه خصائصه الجسمانية من عوار ظاهر فقط دون ما يكون خافياً من ذلك على العين المجردة ، كما يحظر علي الوسـيط كـلكف ، الكشف عن الميـول الجنسية للعميـل ، إلا مـا كـان منهـا ذو صــله بالاضطر ابات النفسية والجسمية المرتبطة بخلل ما في الهوية الجنسية للعميل ، خاصـة ما إذا كان هذا الخلل يصل لارجة التحول الجنسي الكامل أو الميول الجنسية الشـاذة ، فإن الوسبط يمتنع عندئذٍ عن القيام بالوساطة من الأصل ، لتخلف أحد شروط الزواج وهو الهوية الجنسية الكاملة للرجل أو المرأة .

وفي ذات السياق ، يحظر على الوسيط أن يكشف العيوب والاختلالات النفسية والعقلية التي لم تتحول بعد لمرحلة الجنون أو تلك التي لم تتتهي بعد بمرض نفسي أو عقلى مزمن ، وما يمكن البوح به من ذلك ، السماح للوسيط بأن يشير إلى توافر بعض الخصائص السلبية أو الإيجابية المرتبطة بالحالة المزاجية للعميل ، كالعصبية الزائدة أو الطيبة المُفرطة ، بينما لا يسمح للوسيط بالإفصاح عن العيوب المزاجية المعتادة إلا إذا كانت تـؤثر على الحالة النفسية إلى درجة تكـاد تصل للآفة الجسدية التي يتوقع تأثيرهـا بـصورة فادحة علـى علاقـة الـزواج المسـتقبلية ، وذلــك كالإصـابة بـالمس والاقترانـات الشيطانية وغيرهـا مـن أوجـه الخلل النفسى البسيط ، فهذا النمـوذج مـن المعلومات التي قد تصل لعلم الوسيط عن العميل المفوض لـه ، ينبغي على الوسبط أن ينقلها للطرف الآخر التزاماً منه بالإفصاح عنها ، شريطة أن يتعدى ضررها أو تتجـاوز قوتها الحدود المعتادة التي يمكن أن تصيب الفرد وفقاً للمتعارف عليه والمعتاد مـا بين الناس ، وأن يكون لها انعكاساً على نجاح الزواج المستقبلى. 
رابعاً:- يجب على الوسيط أن يتقيد فى إدارته لجلسات الحوار والنقاش والتوفيق

بقواعد ومحساذير الخلـوة بـين الرجل والمـرأة ، لأن استحلال الخلـوة بـين الراغبين فى الزواج بحجة التعارف رأى فاسد ومخالف للضوابط الشرعية ؛ لأن كل منهمـا أجنبي عن الآخر ، وللخلوة بينهمـا مضارا كثيرة على الفرد والمجتمع ، فهى أصل كل بلية وشـر ، وهى سبب لكثرة الفواحش وجرائم الزنا التى فاقت التصور والحدود ، والخلوة قد تؤدى إلى الانحلال والمجون والإباحية ، ومن ثم يحظر على الوسبط أن يُمكن طرفي العلاقة الراغبة فى الري الزواج مسن الخلـوة غير الشرعية ، وأن تتم جميع جلسات الحوار بصورة

جماعية وفى حضور محارم من الطرفين.( (1)

\section{الإطلب الثاني}

\section{هدى خضوع وساطة التوفيق للمفهوم العقدي}

\section{وخصائص العقد المبرم بشأنها}

وينقسم هذا المطلب إلى فرع أول يتولى تحديد إشكالية مدى خضوع العلاقة بين وسـيط التوفيق وراغبـي الـزواج للمفهـوم العقدي ، وفى الفـرع الثـانى نتـولى بيـان خصائص العقد الذى نتصور إبرامسه بين طرفى علاقة الوسـاطة على فرض خضوعها لمفهوم التصرف القانونى ، وذلك على النحو التالى :-

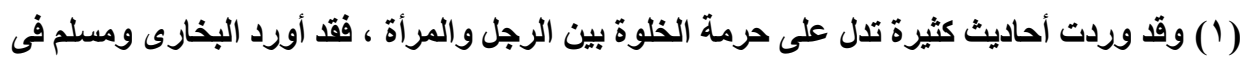

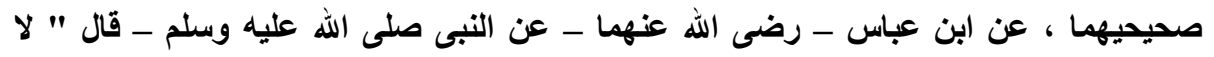

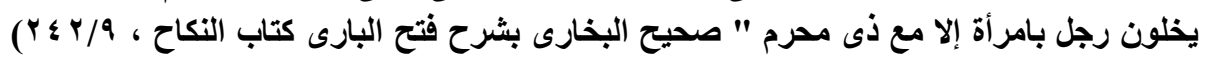

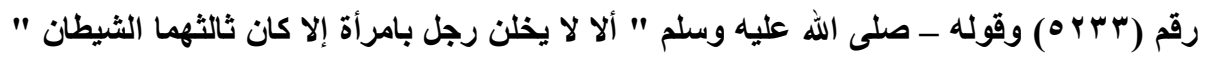

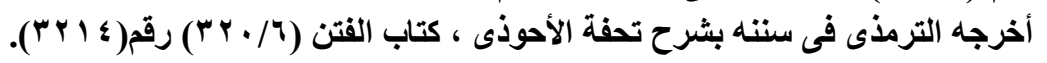


الفرع الأول :- مدى خضوع العلاقة بين وسيط التوفيق وراغبي الزواج للمفهوم العقدي.

الفرع الثاني :- خصائص عقد الوساطة للتوفيق بين الراغبين فى الزواج.

\section{الفرع الأول}

\section{مدى خضوع العلاقة بين وسيط التوفيق وراغبي الزواج للمفهوم العقدي}

تتبلور إثـكالية البحث في تحديد طبيعة العلاقة بين وسيط التوفيق وراغبي

الزواج في تحديد دور الإرادة في تكوين علاقة تعاقدية متكاملـة الأركان يمكن البنـاء عليها لإحداث أثر قانوني بين طرفيها ، وترجع هذه الإشكالية في خصوص علاقة التوفيق محل الاراسة ؛ إلى أن نطاق العقد ومجاله ينحصر في دائرة المعاملات المالية التي تنظمها قواعد القانون الخاص ، فيخرج من نطاقه الاتفاقات التي تنظمها قواعد

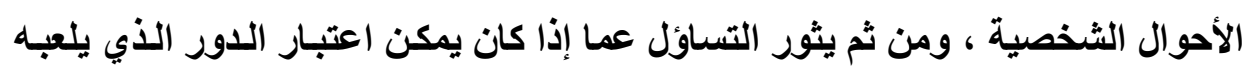
وسبط التوفيق في سبيل إبرام عقد الزواج صورة من صور التعبير عن الإرادة التعاقية بحيث يصلح لبناء أتفـاق تعاقدي بينها وبين راغبي الزواج ، أم أن مـا يقوم بـه وسيط

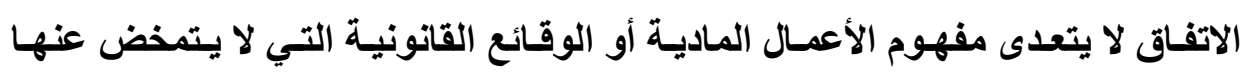

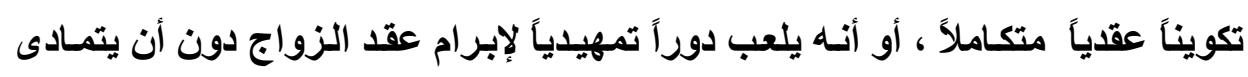
مضمونه إلى فكرة إبرام العقد بـالمفهوم القانوني ، ومن أجل استيفاء تلك الإثكاليات فإنتا نرى ضرورة التمييز بين الوساطة للزواج وبعض الأنظمة التي قد تتشابه معها ، ونرى لذلك أنه يكون من المناسب تقسيم هذا الفرع إلى النقاط التالية : 


\section{أولاً :- التمييسز بـين عمليسات التوفيسق بـين راغببي الـزواج وبـين الوقـائع}

\section{القانونية}

تُعرف التصرفات القانونية ، بأنها الأعمـال التي تتجه فيها الإرادة إلى إحداث اثر قانوني و تشمل العقد و الإرادة المنفردة ، ولا فرق في أن يكون هذا الأثر إنشاء حق شخصي أو عيني أو تعديله أو إنهائه. ويقصد بالواقعة القانونية الأعمال التي لا أثر فيها للإرادة في أحداث اثر قانوني ، و نميز فى هذا المجال بين الوقائع المادية كالوفاة و التي لا دخل للإرادة فيها ، و بين ما يسمى بالوقائع الاختيارية أو الوقائع غير المادية كالقيادة بأكثر من السرعة القانونية المقررة. ويتمثل الفرق بين التصرف القانوني و الواقعة القانونية ، فى الدور الذى تلعبه الإرادة فى ترتيب الآثار القانونية التى يمخضها التصرف القانونى فى ذمـة عاقديها ، في حين أنـه لا دخل لإرادة الأفراد في إحداث هذه الآثثار في الواقعة القانونيـة وإنمـا

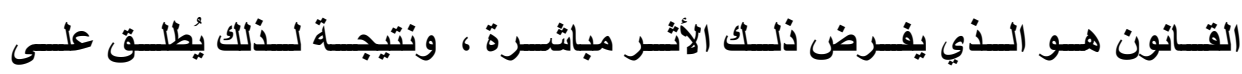
التصرفات القانونية المصادر الإراديـة للالتزام وعلى الوقائع القانونية المصادر غير الإرادية له (') - (1)

وبإنزال هذه الفروق بين الوقائع والتصرفات القانونية على طبيعة العلاقة التى تنشأ بين وسيط النكاح والعميل ، يتبين أنها تتسم بالعلاقة التعاقدية متكاملة الأركان ولا يمكن بحال إنزال مفهوم الواقعة القانونية عليها ، إذ كلمـا أمكن التثبت من وجود أتفاق كان محصلة لتطابق الإيجاب مع القبول فإن العلاقة التي تنشأ بعد هذا التطابق

(1) ويضيف بعض الثرائح الى مصادر الالتزام مصدرين جديدين هما : الحكم القضائى النهائى القابل

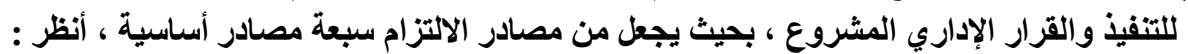

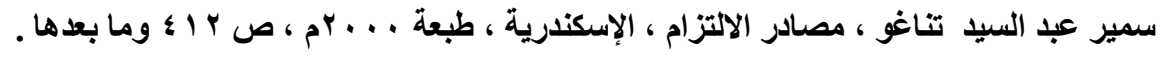


ينطبق عليها وصف المفهوم العقدى ، وإذا كان الأصل في التعاقد أنه يتم بمجرد تبادل الطرفين التعبير عن إراداتهما ، فيتم العقد بتطابق الإيجاب و القبول ، فإن عقد الوساطة يمثل نموذجاً حقيقياً لهذا التكوين القانوني ، لأنها ينعقد بين الوسبط والعميل بمجرد التعبير عن الرضساء ، فالعميل يعبر عن إرادتهـ بالرغبة القاطعة في تفويض الوسبط بالبحث عن شريك حيـاة مناسب سـواء أكـان التعبير عن الإرادة بـاللفظ أو بالكتابـة أو بالإشارة ، ثم يلقى هذا الإيجاب قبول الوسيط الذي يبدى استعداده بالموافقة على تنفيذ طلب العميل محل إيجابه لقاء أجر يتلقاه الأول من الأخير .

ويبدو جليـاً أن التعبير عن الإرادة الـصادر عن العميل فى الصورة المتقدم

وصفها يكون تعبيراً متكامل البنيان القـانونى ، أي أن الإيجـاب الصادر عنه يتضمن جزء من العناصر الأساسية لعقد الوساطة المراد إبرامـه ، ويتحقق ذلكك بـالنظر إلى أن العميل يقرن بإيجابـه جميع الشروطوالخصائص الجوهريـة التي يتطلب توافرهـا فى شريك حياتهـ المتوقع ، وهو مـا يؤكد على دلالـة التعبير بالإيجـاب الصادر عن إرادة العميل وكونـه باتـاً جازمـاً فـى دلالتـه على طلب تفويض الوسيط فـى عمليـة التوفيق والبحث ، فالعميل لا يقصد مجرد استطلاع رأي الوسيط فيما يدعو إليه من التعاقد فإن هذا على فرض حصوله لا يكون إيجاباً تعاقدياً وإنما يكون من بـاب الدعوة إلى الدخول في مفاوضـات حول الوسـاطة المتوقعة ، وهذه المفاوضـات قـ تطول أو تقصر وقـا تنتهي إلى عرض بات من أحدهما ، أي إيجاب يقبله الطرف الأخر فينعقد العقد ، وقد لا تنتهي المفاوضات إلى تحقيق شيع ذلك ، فيمكن حينذذٍ القول بأن هناك واقعة قانونية تمت فى ظلال الفترة مـا قبل اللخول فى عمليـات الوسـاطة وتنفيذها فعلياً ، وهذا فى مجمله يؤكد أن للإرادة دوراً بارزاً فى إبرام عقد الوساطة للتوفيق بين الوسيط والعميل الر اغب في الزواج ، وأنه لهذه الإرادة الحرة الواعيـة أثراً قانونيـاً يتخلف فى ذمـة 
الوسيط وعملائه عبارة عن التزامات تعاقدية جادة ونافذة يحتم عليهما العقد الوفاء بها ، وهو مـالا يــع مجالاً للشك بـأن علاقة الوسبط بالعميل هى محض تصرف قانوني

متكامل الأركان والشروط.

كمـا ممـا يحفز إلى القول بالطبيعة العقديـة لعلاقـات التوسط بين الراغبين في

الزواج ، ونفى وصف الواقعة القانونية عنها ؛ إلى أن البحث عن شريك الحيـاة من خلال وسيط ، إنما يخالف الأصل الفطري وعادات المجتمع فى الغالب تحصر هذا الأمر في النطاق الأسـري الذي تهيمن عليسه عوامـل السرية والخصوصية ، ومـن ثم فبان الاعتبـارات الخلقية والاجتماعية فضلاً عن متطلبـات السرية والخصوصية التي يقوم عليها نظام الزواج تمنع من اعتبار المهمة التى يناط بها وسيط التوفيق عملاً مادياً في كل مـن المفهوم والتطبيق والأثر ، ومـن ثم فـلا نتصور أن يكـون الـلـول في هذه

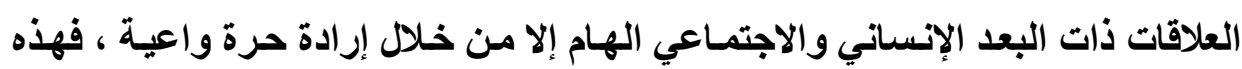
العلاقات الإنسانية المتميزة لا بل وأن يُغلب عليها الطابع التعاقدي وأن تنأى بها مكانتها عن مفهوم الواقعة القانونية ، بأن تلعب فيها الإرادة دوراً بارزاً يتفق مـع سمو العلاقة الشرعية التي يهدف الأطراف لإبرامها من خلال علاقة الوساطة في التوفيق.

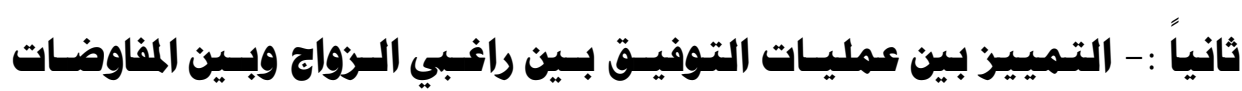

\section{والاتفاقات السابقة على التعاقد.}

يمكن تعريف التفـاوض السابق على التعاقد بأنسه تبـادل اقتراحات ومسـاومات ومكاتبات وتقارير ودراسات يتبادلها الأطراف للتعرف على الصفقة المزمـع إبرامها، وعلى ما سوف يسفر عنه الاتفاق من حقوق والتزامات على عاتق الطرفين، وذلك من

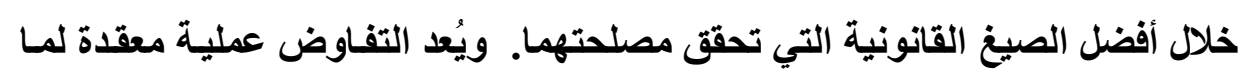


يتخلاها من محاورة ومساومة ومراوغة ، يتبادلها المتفاوضين، فكل طرف يستعرض مهارته التفاوضية في هذا الثأن، من أجل الوصول لتحسس مصلحته، وجس نبض الطرف الآخر، لتكوين فكرة عن التعاق، وصولا لتحقيق الغاية المقصودة، وبما يضمن لله عدم الالتزام بالعقد المزمع إبرامه إلا في التوقيت الذي يريده هو، وفي التوقيت الذي يضمن فيه التزام الطرف الآخر بأكبر قدر من الالتزامات، وبما يحقق أقصى منفعة من الصفقة محل المفاوضة نظير أدنى مقابل . (') وتتسم مرحلة المفاوضـات بأنها تحفل بالمساومات والأخذ والرد بين أطراف المفاوضة، حيث يسعى كل طرف إلى إقنـاع الطرف الآخر بمـا يريد، لذا فهي تتضمن عروضاً واتفاقات متلاحقة يتم اعتمادهـا من المتفاوضين، وهذه الاتفاقـات والعروض ليست باتة، ولكنها يمكن أن تمهـ لإيجاب بات. ويقصد بالتفـاوض المقصود هنـا، هو ذلك الذي يتم في المرحلة قبل العقدية والذي ينتهي عـادة بالاتفـق أو بعدم الاتفـاق. وعليه فكل طرف في هذه المرحلة يتلمس طريقه إلى التعاقد المطلوب في جو من التردد والحذر، فهي لذلك تعد بالمرحلة الاستكشافية، حيث يستكشف فيها كل متفـاوض مـا

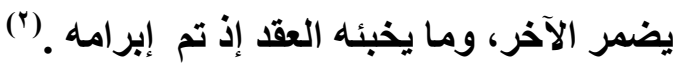
وخلافًا للمفاوضات السابقة لإبرام العقد ، قد يلجـأ أطراف العلاقة التعاقيـة في بعض الحسالات إلى إبرام بعض العقود التـي يكون من شـأنها أن تمهـ للعقد النهائي المقصود ، أذ يمكن أن يكون أبرام العقد النهائي غير ممكن عملياً ومادياً ، ومن ثم يتت

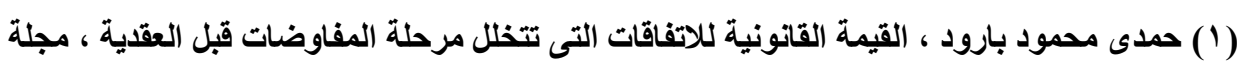
الجامعة الإسلامية ،(سلسلة الدراسات الإنسانية ) ، المجلد الثالث عشر العدد الثانى ، يونيو 
تمييز هذه الصورة من التعاقد مثثلاً عن العقد المعلق على شرط ، فالعقد الأخير يمثل العقد النهائي، وهو مقصود لذاتـه فلا يُمهـد لعقد أخر وكل مـا يميزه هو أن وجوده أو استمراره معلقان على تحقق شرط معين (' ) ، للكك فإن البعض يعرف العقد التمهيدي بأنه "ذلك العقد الذي يسبق أبرام العقد النهائي المنشود والذي يكون بدوره ممهداً

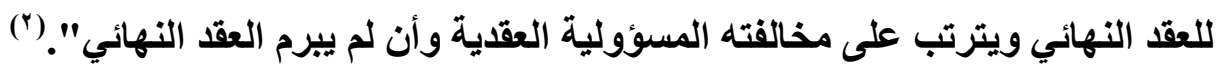
وبمقارنـة طبيعـة عمليـات الوسـاطة الزوجيـة بمفهوم المفاوضـات التى تسبق التعاقد ، أو بالعقود التمهيدية الموطئة لإبرام العقد النهائي ، يتبين أن الوسـاطة محل هذه الاراسـة تختلف عن مضمون الأمرين السـابقين اختلافـاً جذرياً ، فالوسـاطة مـن ناحيـة ، ليست مـن قبيـل المفاوضـات السـابقة على التعاقدات ؛ لأنهـا ليست مجـرد حوارات وحلقات نقاش يطلقها الأطراف الراغبين فى الدخول إلى علاقة زواج شرعية مع الوسيط بقصد استكشاف قدراته على البحث والتوفيق ، بل يتضمن لجوء العميل للوسيط قيام الأول بـالتعبير للثانى عن الإرادة الباتة الجـادة المقترنة بقصد الارتباط بالمتعاقد معه والذي يقوم به العقد إذا لحقه قبول مطابق ، وهو لا يكون كذلك إلا إذا صدر في صيغة عرض غير مشروط ، متضمنا تحديداً واضحاً لكل الأركان الرئيسية للرابطة المزمع إنشاؤها ـ فالذي يُميز الإيجاب الصادر عن العميل عن اللاخول في مفاوضات مع الوسيط في سبيل الوصول إلى إبرام عقد الوساطة ، هو وجود أو عدم وجود النية القاطعة في الارتباط بالتعاقد ، فإن وجدت هذه النية كنـا أمسام إيجاب بـات ، وان لم توجد كنا أمام مجرد دعوة من العميل للاخول في مفاوضات مع الوسيط ، فبإذا (1) جمال فاخر النكاس ،العقود والاتفاقات الممهية للتعاقد وأهمية التفرقة بين العقد والاتفاق في

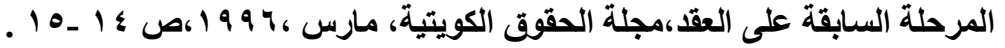

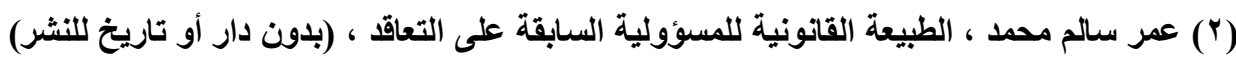


كان التعبير مجرد دعوة إلى المفاوضة ، فان قبول هذه الدعوة لا يؤدي إلى إبرام عقد

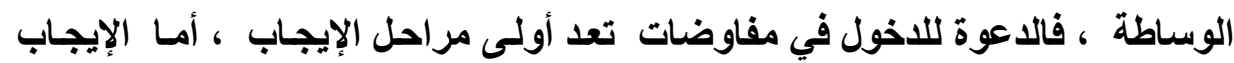
ذاته فيمثل خطوة مباشرة إلى العقد ، حتى إذا ما قبله الطرف الآخر قام العقد فوراً ، ولا شك فإن تفويض الوسيط فى البحث والتحري عن زوج المستقبل ، والاتفـاق معه على

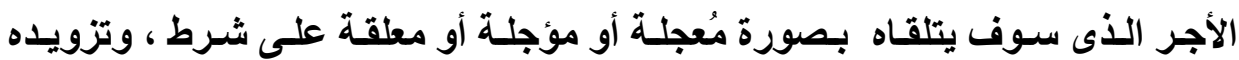
بالبيانـات والمطلومــات الخاصـة بالهويـة الاجتماعيـة والوظيفيـة ، وتـسليمه الـصور الفوتغرافيـة والسيرة الذاتيـة للعميـل ، وإعلامسه وتبـصيره بالـصفات والاشـتراطات المتطلبة فى شريك الحياة الزوجيـة ، كل ذلك يعتبر نموذجـاً واضحاً للكشف عن إرادة باتـة جازمـة لكل مـن العميل والوسـيط لإبرام عقد الوســاطة ؛ وذلك لمـا تشكله هـذه الحقائق من مراحل متقدمة من الإيجاب والقبول المنطابقين واللازمين لانعقاد العقد بين طرفى الوساطة فى الزواج ، وهو ما يرفع عن هذه العلاقة مفهوم المفاوضسات مـا قبل إبرام العقد بصورة كلية. ومن ناحية أخرى ، فلا يمكن اعتبار عقد الوساطة من العقود التمهيدية كذلك ، لأنه عقد نهائى بطبيعته ؛ حيث لا تختلط أركان هذا الاتفاق بأركان عقد الزواج المزمـع إبرامه فى نهاية المطاف (') ، فركن الرضا في عقد الوساطة يعبر عن إرادة العميل في

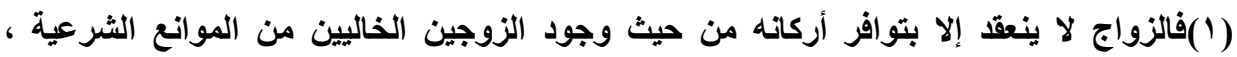

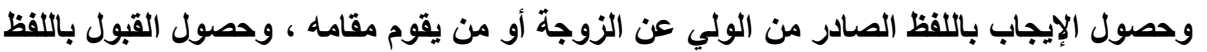

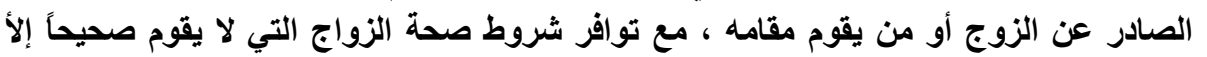

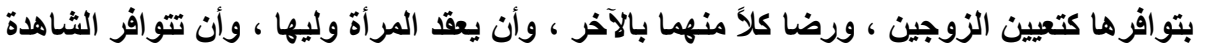
على النكاح . أنظر في بيان هذه الأركان والثروط بالتفصيل ؛ محمد رأفت عثمان ، عقد الزواج ، أركاته وشروط

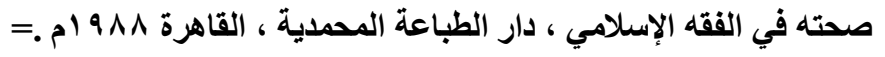


تفويض الوسيط للبحث عن شريك حياة بمواصفات خاصة ، ويتمثل المحل في هذا العقد في طاقات الوسيط ومهاراته المهنية فى البحث والتوفيق فضلاً عن الأجر الذي يؤديه. العميل مقابل ذلك ، وأخيراً فأطر اف عقد الوسـاطة همـا الوسبط والعميل وليس أطراف عقد الزواج ذاته ، وبذلك يتبين أن عقد الوساطة وإن كاتت الغاية الأساسية من إبرامه تتمثل فى إبرام عقد الزواج ذاته ، إلا أنه بالنسبة للزواج ليس من العقود التمهيدية التى تبرم بغرض إبرام الزواج مباشرة بحيث يكون نتيجة للوساطة. يؤكد ذلك من جهة اخرى ، إن التزام الوسيط بالتوفيق بين عملائه التزام غير مضمون بنتيجة ، فالوسيط يبذل كل المساعى ويستعمل كل مهارات الإقناع لأحداث حالة مـن الانسجام بـين الطرفين دون أن يكون ملتزمـاً بتحقيق هذه الحالـة ابتـاءً كنتيجـة معلومة أو مشترطة أو مضمونة مسبقاً للعميل ، فضلاً عن أن دور الوسيط يتوقف عند حد تحقيق القبول والانسجام بين الطرفين دون أن تنصرف التزاماتـه لمرحلة إبرام الزواج بينهمـا ، ليترك للطرفين فيمـا بعد ذلـك اسـتكمال مراحل التفـاهم والتفـاوض المُمهدين لمرحلة الخطبة والزواج الثرعيين ، فهذه المرحلة الأخيرة يستقل الطرفين بتحديد ملامحها وتسوية أركانها وشروطها دون تلخل مباشر من الوسيط الذي ينتهي دوره عند حد التوفيق الأي يتحقى بقيام حالة القبول والرضا بين الطرفين ، لذلك فعقد الوساطة يستقل تماماً عن عقد الزواج ولا يشكل عقداً ممهداً لله لأن الوسبط قد يفشل فى تحقيق القبول ولا ينعكس إخفاقه على قيام عقد الوساطة وبقائه مرتباً آثاره فى ذمـة

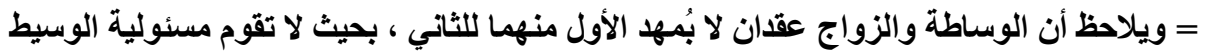

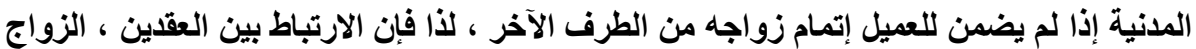

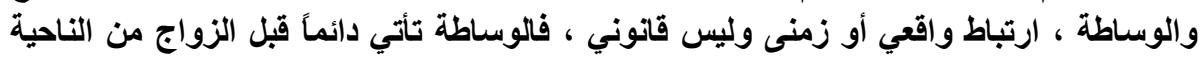

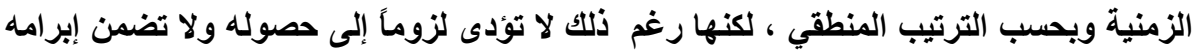
بين طرفيه الراغبين فيه. 
العميل ، وهذا ما يؤكد انفصال العقدين ، الزواج والوساطة ، فكلاهما لا يشترط لوجوده أن يتحقق وجود الأخر ، بل وقد ينعقد أحدهما دون أن يتولد الثاني من الأصل. ثالثاً : - هظاهر الدور الذى يلعبه سلطان الإرادة في إثبات الفهـهوم التعاقـدي

\section{للعلاقة بين وسيط التوفيق وراغبي الروفاج .}

إذا كاتت التشريع المصري قد جاء برمته خلواً من تنظيم قانوني يستقل بتوضيح

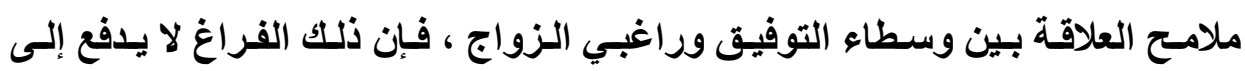
الاختلاف بشأن تحديد طبيعة هذه العلاقة ومضمونها القانوني ، خاصة مع تنامي الدور الأي تلعبه الإرادة في شأن اعتبار هذه العلاقات موصوفة بالتكييف التعاقدي المحض ، بعدما خلصنا إلى أنها ترقي عن مفهوم الوقائع القانونية ، وتختلف اختلافاً جذرياً عن طبيعة الاتفاقات والمفاوضات السابقة على التعاقد ، ومن ثم يمكن تطبيق القواعد العامة لنظرية العقد فى العلاقة المبرمة بين الوسيط وعملائه.

وإذا كاتت الخطبة هى أقرب الأمور التى يمكن مقارنـة الوسـاطة بها بوصفها

تؤدى إليها وتبتغى تحقيق رغبـة الطرفين فيها ، فِإن الأمسر يقتضى المقاربـة بينهــا لتحقيق توافر الصفة العقدية فى الوساطة من عدمه ، إذ يذهب أنصار نظريـة العقد في محل الخطبـة ، خلافـاً لمـن يقول بأنهـا مجرد وعد بـالزواج ، إلى أنهـا تعد عقداً بين طرفيها ، وهو عقد صحيح بالنسبة إليههـا(') ، وقد بدأت هذه الفكرة تظهر في الفقهـ الفرنسي منـذ القرن التاسـع عشر ، فقــ اعتبرهـا هذا الفقـه عقداً يرتب التزامـاً بعمل

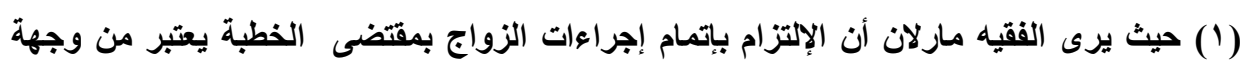

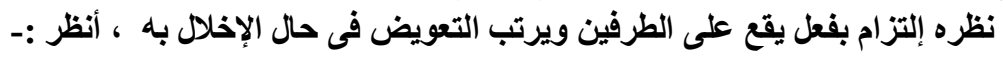

- LAURENT AYNES, Principes de droit civil Français, tome 2 ,3éme édition, Bruxelles ,1978, $\mathbf{n}^{\circ} 404$-405.

NV0 مجلت البحوث القانونيت والإقتصاديت 
يتحول عند الإخلال به إلى حق الطرف الآخر التعويض ، واستتد في هذا الاتجاه للقاعدة

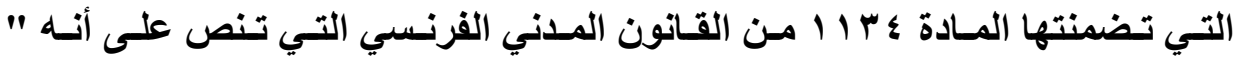
الاتفاقـات التي تتثم على وجـه شـرعي تقوم مقـام القـانون عن عقدها" ، لـللك تعتبر الخطبة لاى هذا الفقه اتفاق صحيح على إبرام الزواج ويكون ملزماً للجانبين. (') وتؤيــ الطوائف غير المسلمة في مصر ذات الاتجـاه ، فـالرجوع إلى الشرائع الخاصة بها ، يتبين أنها تُعرف الخطبة بكونها عقد بين رجل وامرأة يعد فيهه كل طرف منها الأخر بالزواج في أجل محدود ، لكن هذه الثرائع الطائفية قد انتظمت الخطبة على نحو يوحى باعتبارهـا من العقود ذات الطبيعة الخاصـة ، وقد استلزمت فيها شـروطاً

موضعية وأخرى شكلية ، تنظم أحكام هذه العلاقة التعاقدية بكثير من التفصيلات .(†)

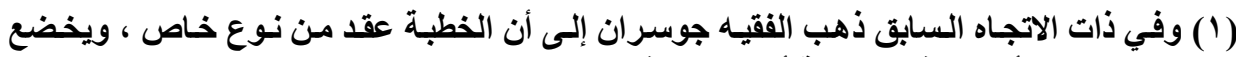

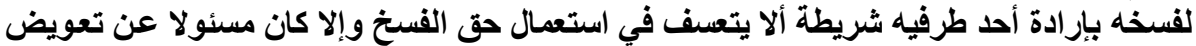

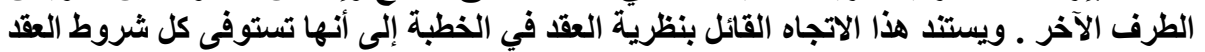

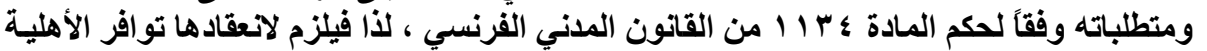

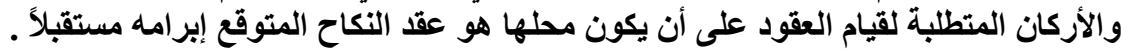

$$
\text { أنظر فى ذلك :- }
$$

-JOSSERAND , Le problème de l'abus de droit ,DH 1967,chr 27, cite par J.

CARBONNIER, Droit civil, tome 2 , La famille, les incapacités, Presses universitaires de Françe, 1983 . n ${ }^{\circ}$.

-MICHEL PLANIOL, et G RIPERT, Traite pratique de droit civil français , 2éme édition, tome 2, L.G.D.J. 1952. $n^{\circ} 81$.

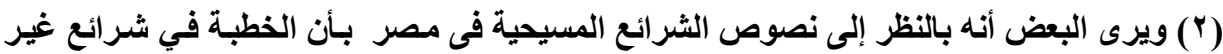

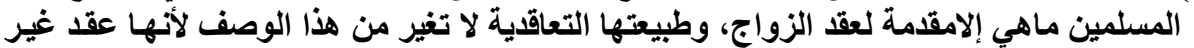

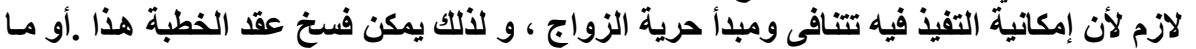

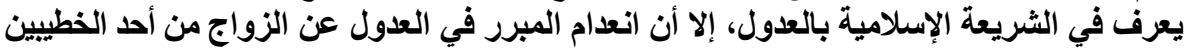

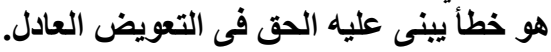
أنظر :محسن عبد الحميد إبراهيم البيه ، الأحوال الثخصية لغير المسلمين ، مكتبة الجلاء الجليدة، 2006، الطبعة الثانية ، ص 235 ـ إيرال 
ومن منطلق اعتبار الخطبة من التصرفات القانونية لاى اتجاه من الفقه السابق بيان مضمونه ، لذا فإن مرحلة الوساطة السابقة عليها والتى يتم فيها التوفيق والتهميد لإبرام عقد الخطبة لا بـ وأن تصطبغ كالخطبة بالصبغة العقدية لتوافر ذات الإرادة التى تنعقد بها الخطبة فى علاقة الوساطة التى تهذف لإتمامها ، وحيث إنه قد انتهينا إلى أن الوساطة ليست من قبيل المفاوضات التى تسبق الخطبة والزواج ولا ثُعد عقداً تمهيدياً لهمـا لأن الوسيط لا يضمن تحقق أيهمـا للعميل ؛ فذلك يؤدى لاعتبار هـا عقداً مستقلاً عنهمـا يتمتع أطر افه بإرادة إبرامسه وبوصفه الاتفـاق الذى يستهـف إبرام الزواج أو الخطبة ، حيث إن الإرادة التعاقديـة التى تصدر عن الزوج أو الخاطب لإبرام هذين العقدين هى بذاتها التى تصدر عن العملاء لإبرام الوساطة بغرض الوصول إليهما ـ إذاً فالوساطة بين الراغبين في الزواج تنشئ علاقات تعاقدية بين الطرفين لا يمكن تجاهلها ، ويتعين إدراجها في مصاف التصرفات القانونية ومحوهـا من نطاق الوقائع القانونية ، خاصة مع هيمنة المفاهيم العقديـة على البنـاء الواقعي فيها وكيفية التقاء الإرادات المتقابلة لطرفيها ، لذلك يكون من غير المقبول تجريدها من أي اعتبار قـانوني ، حيث في الوسـاطة يصدر إيجـاب يلتقى بقبول على البحث والتوفيق بـين شريكين يتوقعان الاخول في علاقة نكاح أصلية ، لذلك فهي تجسد ارتباط قانوني وعقد

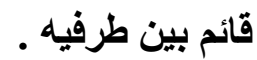

وتظهر بذلك دوافع الانتصار لمفهوم الرابطة العقدية في العلاقة ما بين الوسبط وعملائه ، في أن توافر وجود طرفين أساسيين في علاقة الوسبط بالعميل ، فضلاً عن توافق إرادتيهما على خلق التزامات متبادلة كنتيجة مباثرة للتعبير الصريح عن الإرادة ، يمـثلان الـافع لإطـلاق مفهوم الرابطة العقديـة تجـاه هذه العلاقة ، فطلب الوسبط

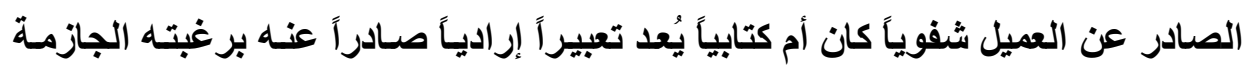


في البحث عن شريك حيـاة وتحقيق الارتبـاط بـه ، ويمثل هذا الطلب ركن الإيجـاب التعاقدي الصادر عن العميل ، ويُعتبر قبول الوسبط للقيام بالمهمـة محل هذا الإيجـاب مقابل أجر محدد من الأمور المُتممة لإبرام عقد الوساطة بمختلف أركانه فيما بينهما ـ كما يؤكد ذلك المفهوم التعاقدي ، أن العميل ليس ملزماً بالالتجاء للوسيط طالباً وسـاطته ، إذ يمكنه تحصيل ذات الخدمـة بمقتضى مجهودات فرديـة يمارسـها بذاتـه ، ويستطيع فى الغالب أن يحصل على شريك حياته بمحض أبحاثه الفردية أو علاقاتها الاجتماعيـة ، كمـا يتمتع العميل فضلاً عن ذلكك بحق الاختيـار للوسيط الذي يرغب تفويضه في البحث عن شريك الحياة ، فلا يمكن إجباره قانوناً على اللجوء إلى الوسبط الأي ياخل في اختصاصه عمليات التوفيق نوعياً أو جغرافياً (')، لذلك فإطلاق حريـة العميل على الوجه المتقدم تُعد دليلاً على الإرادة التعاقدية الحرة ـ كمـا أن خلو التشريع المصري من نصوص قانونيـة تلزم الوسبط بـإجراء عمليـات التوفيق إذا مـا طلب منـه الإدها العميل القيام بها ، يكفي لإثبات تمتعه بالحريـة المُعتبرة أساسـاً للقول بالطبيعة العقديـة

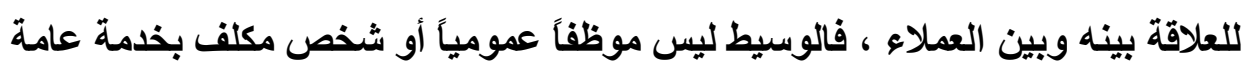
حتى يُمكن إلزامه بإجراء عمليات وساطة النكاح دون تطلب ركن الرضا في موافقته.

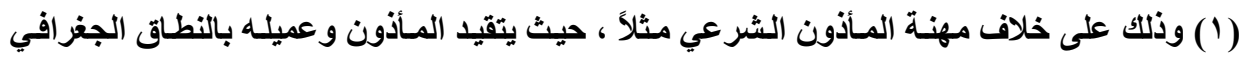

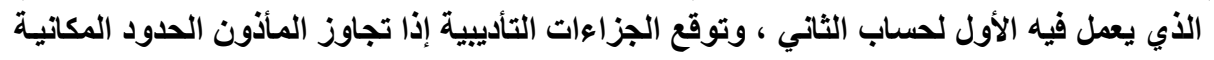

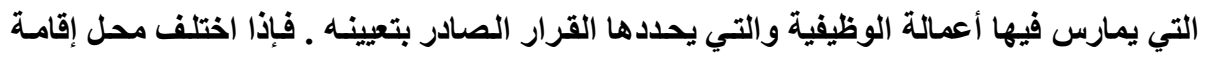

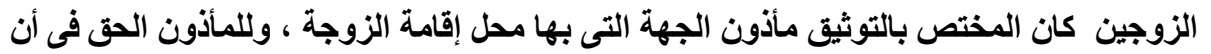

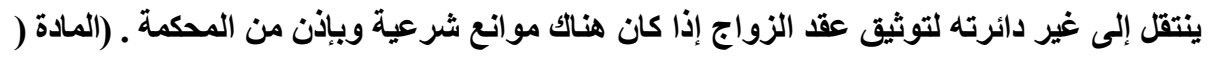

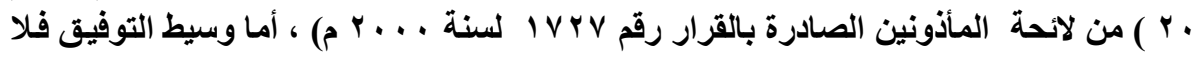

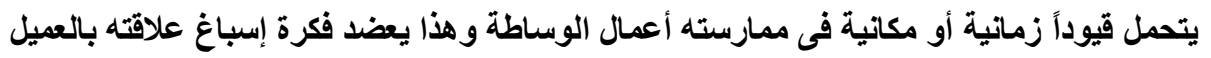


كما يُستنبط وجود الرضا المُتبادل ببين العميل ووسيط النكاح من خـلال حريـة متبادلة للطرفين في تحديد المقابل الذي يتلقـاه الوسيط من العميل لقـاء مـا يؤديـه الأخير من التزامات عقدية بالبحث والتوفيق ، ولا يعني وجود بعض الحالات التي ينتفي فيها تلقي الوسيط للأجر أن يتم إنزال طبيعتها على الأصل الواقعى الغالب والمُستقر فى الوسط المهنى المحترف(') ؛ لأن هذه الحالات تتسم بكونها ذات طابع استثنائي بحيث لا تصلح لتعميم حكمها ، حيث الدارج عملاً أن يتلقى الوسيط الأجر دفعة واحدة أو على دفعـات مرتبطـة بمر احل إنجـاز التزاماتـهـه ، وسـواء أكسان الوسـيط فرديـاً أو يعمـل في صـورة مؤسسـة ذات طسابع اجتمـاعي أو تجـاري ، فهـو يهـدف أسـاسـاً مـن ممارسـة أعمــال الوساطة إلى تلقي المقابل المادي الذي يُمكنه من الوفاء برواتب تابعيه وسداد ما يتكبده من تكلفة البحث واتخاذ مقر ثابت له والإنفاق على مختلف مراحل التوفيق . ولاشك فبإن استقرار الر أي حول وصف الاتفـق المبرم ببين العميل ووسيط النكاح بكونه من الروابط العقدية يؤدي إلى انعكاس ذلك على تأسيس مسئولية الوسيط

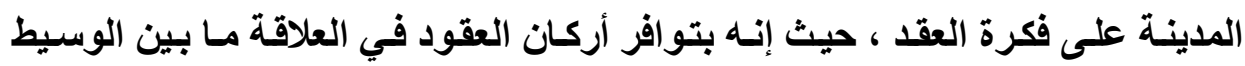
والعميل ، وأهمهـا أن العميل يتمتـع باختيـار الوسـيط الذي يرغب أن يفوضسه لانجـاز رغيته في الارتباط ، وأن المقابل الذي يتلقاه الوسيط لا تتدخل اللوائح والقوانين في تحديده بقواعد مسبقة ، لذا فإن أركان العقد الأساسية تغدو بذلكك متوفرة وجلية في جاتب العلاقة التي تقوم بين الوسيط وعملائه ، وهو ما يدفع لتأييد فكرة قيام المسئولية المدنية للوسيط على أساس من العقد المبرم بينه وبين العميل.

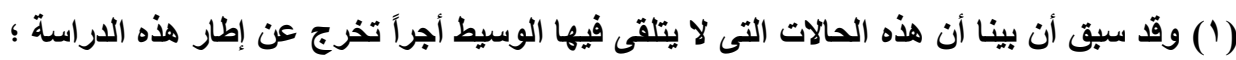

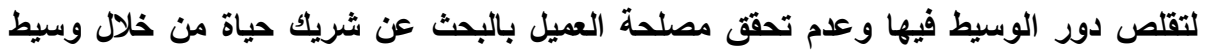
محترف وبارع. أنظر سابقاً الفرع الأول من المطلب الأول. 
وفى الحقيقة ، إن انتفـاء الصفة العقديـة على علاقة الوسبط بالعميل ، وعلى فرض صحته ، قد يفضى إلى انعكاس هذا التكييف في مجال الإثبات ، فمن الصعوبات التي تواجـه العميـل نتيجـة لتبنـى المفهوم التعاقدي مشكلة إثبـات خطـأ الوسـيط التـي سيكون أمراً عسيراً على العميل باعتبار الوساطة اتفاقًا يخضع لقواعد إثبات التصرفات القانونية ، مما يلقى على العميل عبئًا ثقيلاً في إثبات توافر أركان العقد ابتداءً ثم إثبات

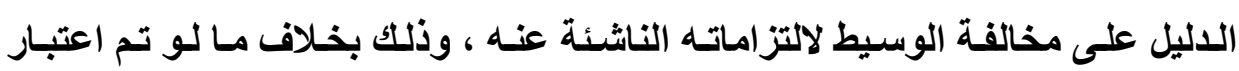
الوساطة عملاً مادياً مما يجوز إثباته بكافة طرق الإثبات المقررة قانونـاً ، فضلاً عن أن التعويض فى نطاق المسئولية التقصيرية يمتد ليشمل الأضرار المتوقعة وغير المتوقعة بينما يقتصر التعويض على الضرر المتوقع فى المسئولية العقدية ، لكن هذه المزايـا لا يمكن الاعتداد بها لما تحققه من تيسير قواعد الإثبات نتيجة إسباغ العلاقة بين الوسيط وعملائه بالطبيعة غير العقدية ، فهذه العقبات لا تسوغ تبني ذلك المفهوم لما يجنيه من فوئد للعميل ، وينبغي إذاً إنزال التكييف الصحيح على هذه العلاقة مهمـا كانت آثارهـا

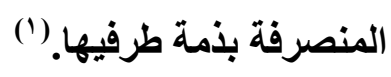

(1) و وعلى العكس من ذلك فإن تبنى المفهوم التعاقدي للروابط الناشئة عن التوفيق بين راغبي الزواج

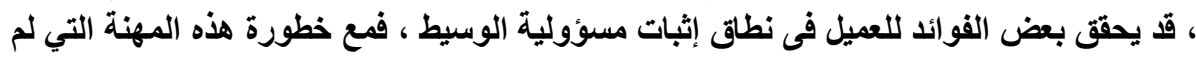

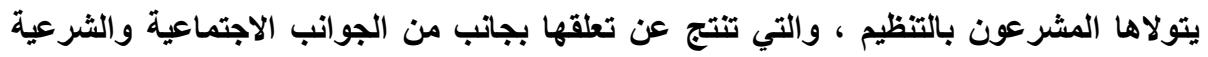

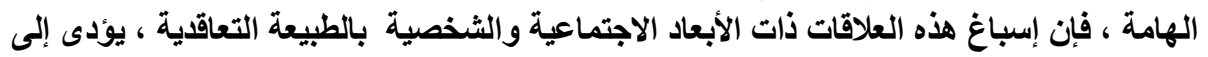

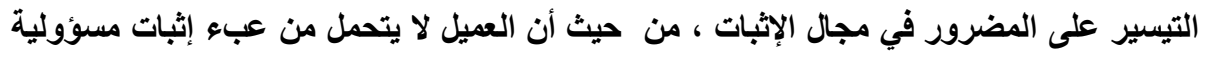

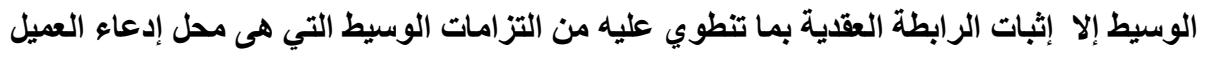

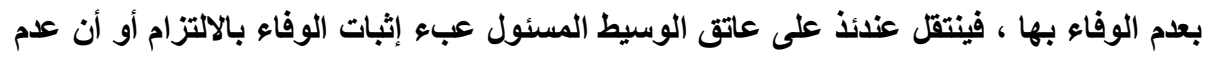
الوفاء يرجع إلى سبب أجنبي. أنظر :محمد أحمد عابدين ، التعويض بين المبند المسئولية العقدية والتقصيرية ، دارة المطبوعات العلمية ،

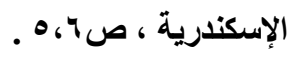




\section{الفرع الثانى \\ خصائص عقد الوساطة بين راغبي الزواج}

بذاعة فإنه يمكتـا تعريف عقد الوسـاطة بين راغبى الأنكحة بأنسه : " الاتفـق الأي يجرى بين شخصين أحدها هو وسيط النكاح ، والثاني يكون العميل الراغب في الزواج ، يتولى بموجبـه الأول ، لقـاء أجر يؤديسه الثاني ، عمليـة البحث عن شـريك الحيـاة الزوجيـة للعميل والتوفيق بينهمـا بغرض إتمـام عقد الزواج". وبصورة أكثر اختصاراً يمكنتـا تعريف عقد الوسـاطة بأنسه " الاتفـاق الذي يبرمسه الوسيط والعميل ، ويلتزم بموجبه الأول بتحصيل زوج للثانى بمواصفات معينة والتوفيق بينهما لقاء أجر "يؤديه الأخير"

وبعد أن انتهينا في الفرع الأول إلى ضرورة إخضاع العلاقة بين وسيط الزواج وعملائه للمفهوم التعاقى المحض ، فلابد إذاً من الانتقال إلى بيـان الخصائص التي يتمتع بها عقد الوساطة محل الدراسة ، والتي يمكن تناولها في النقاط الآتية :-

\section{أولاً : عقد الوساطة هن العقود الرضائية.}

لأنسه ينعقد بمجرد التعبير عن الرضـاء ، أيـاً كانـت الطريقـة التي يتم بهـا هذا التعبير ، فالمتعاقدين فيه هم الذين يختارون بمحض إرادتهم الحرة للشكل الذي ينبغي أن يصدر فيه دون أي تلدخل من جانب المشرع ، فللعميل أن يعبر عن إرادته بالرغبة في تفويض الوسيط بالبحث عن شريك حياة مناسب سواء أكسان التعبير عن الإرادة باللفظ أو بالكتابة أو بالإشـارة ، وله كذلك أن يعبر بأي سلوك من جاتبه يصلح للتعبير عن الإرادة سواء كان سلوكاً إيجابياً أم سلبياً ، وسواء أكان صريحاً أم ضمنياً . 
لذلك يكفي لانعقاد عقد الوساطة بين العميل ووسيط النكاح الشرعي أن يتطابق الإيجاب والقبول فيما بينهما على محل وسبب مشروعين ، ويستوي فيمسا بعد وسـائل تحقيق هذا التلاقى بين إرادتيهمـا ، فقد لا يدرك العميل حاسـة الكـلام أو مهـارة الكتابـة ويعبر عن إرادتهه في تفويض الوسبط بالبحث عن زوج بواسطة الإشـارة أو الإيمساء إعمالاً لمبدأ الرضائية.

ومن الملاحظ أن عقد الوسـاطة محل البحث يغلب أن يكون مدوناً في محرر ،

حيث إن مكاتب الوسـاطة التي أصبحت منتشرة في كثير مـن المنـاطق ، فضلا عن المواقع الالكترونية المتخصصة في الوسـاطة لتلاقي راغبي الزواج ، تشترط كلاهمـا في المتقدمين إليها ملئ استمارة بيانات محررة مقدماً من قبل مكاتب الوساطة ، وبعض التص المكاتب تشنرط سداد رسم تسجيل عند لحظة ملئ البيانـات المسجلة فى نموذج معين. ويلاحظ أن تدوين بيانات العميل في استمارة البيانات المذكورة ، لا يحرم عقد الوسـاطة

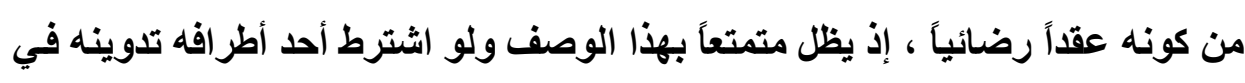

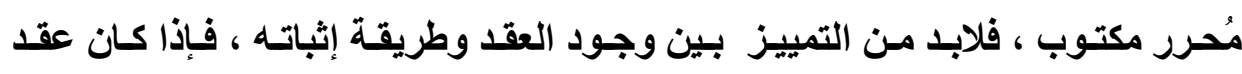
الوساطة ينعقد بمجرد التقاء الإيجاب بالقبول ، لذا فهو يبقى من العقود الرضائية ، ولا

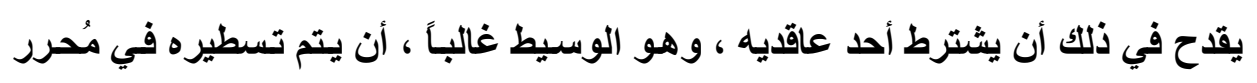
مكتوب ومُوقع في صورة طلب مُقدم من العميل.

\section{ثانياً: عقد الوساطة هن العقود الملزهة للجانبين.}

العقد الملزم للجـانبين هو العقد الذي يرتب التزامـات متقابلة في ذمـة كل من

عاقديه ، فالتزامات أحدها تعد حقوقاً للطرف الآخر ، ولا يختلف هذا الوصف عن عقد

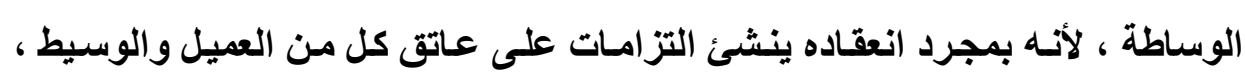


فيصبح كل منهما دائناً ومديناً للآخر ، فالتزام الوسيط بالبحث عن شريك مناسب للحياة الزوجيـة وفق الشروط التي يفرضـها العميل ، والتزامسه بمحساولات التقريـب وإدارة المفاوضـات بـين الطرفين ، يقابلـهـ التزام العميل بـأدع الأجـر وتمكين الوسـيط مـن الحضور في جلسـات التوفيق ، وكمـا هو واضـح يوجد ارتبـاط بين التزامـات الوسبط والعميل ، يجعل كلاً منهما سبباً لالتزامات الآخر ، فإذا امتنع أحدهما عن تنفيذ التزاماته جاز للطرف الآخر أن يمتنع هو أيضاً عن تنفيذ الالتزامات المقابلة أو أن يطلب الفسخ ليتحلل من العقد تمامـاً ، وإذا استحال على أحدهما تتفيذ التزامـه أنقضى هذا الالتزام بسبب استحالة التتفيذ ، وانقضى معه الالتزام المقابل لـه ، أي ينفسخ عقد الوسـاطة حينئذ من تلقاء نفسه لاستحالة التنفيذ. ثالثا : عقد الوساطة هن عقود المعاوضات.

عقد المعاوضـة هو ذلك الاتفـاق الذي يتلقى فيه كل من المتعاقدين مقابلاً لمـا أعطاه ، وعقد الوساطة لا يتخلف فيه هذا الوصف ، لأن كل من الوسيط والعميل يأخذ مقابلاً لما يلتزم به تجاه الطرف الآخر ، لذلك يعتبر عقد الوسـاطة من الأعمـال الدائرة بين النفع والضرر ، لذلك يلزم لإبرامه توافر أهلية معينة هي أهلية التصرف ـ ويلاحظ أن أهلية العميل لإبرام عقد الوساطة يستلزم فيها أهلية من نوع خاص، فيلزم أن يتوافر في طالب الوساطة أن يكون في سن قانوني يسمح لـه بـالزواج ، إذ لا يجوز إبرام عقد الزواج إلا لمن هو حائز للسن المحدد في قانون الأحوال الثخصية وللقواعد التي تنظمها لوائح المأذونيين الثرعيين .

وعقود التوفيق بين الراغبين في الزواج من عقود المعاوضـات مُحددة القيمـة وينتفي عنه الصفة الاحتمالية ، لأن كلاً من طرفيه يعلم مسبقاً ، ومنذ لحظة إبرام العقد 
، قدر ما يلزم بإعطائه وقدر ما يأخذ مقابلاً لذلكك ، إذ الدراج عملاً أن يشترط الوسيط سواء أكان وسيطاً فردياً أم مكتب مُرخص أن يلتزم العميل بسداد مبلغاً محدداً من المسال ، إذا ما نجح الوسيط في إيجاد شريك مناسب لابرام عقد الزواج المحتمل ، وذلك مقابل ما يعلمه العميل مقدماً من المجهودات التي ينبغي على الوسيط أن يبذلها إزاء تحقيق غايته من التعاقد معه .

رابعاً :- عقد الوساطة هن العقود الفورية التى يتراخـى تنفيـذها لفـترة هـن الزمهان.

عقد الوساطة بطبيعته ، ينشأ بين طرفيه التزامات متبادلة ، يستمر تنفيذها فترة من الزمان ، أو يتكرر تتفيذها عدة مرات ، حيث يمكن للوسيط أن يفشل في إحضار الثخص المناسب للعميل ، فيضطر إلى إجراء مجموعة من المحاولات المتكررة من البحث و التوفيق بين العميل وشخص آخر قد يحوز قبولـه ، ومن ثم فِان الزمن يعتبر عنصراً جوهرياً في عقد الوساطة ومعياراً لتنفيذ الالتزامات الناشئة عنه خاصة منها ما يرتبط بطبيعة أعمـال الوسـيط ، التي غالبـاً مـا تستدعي زمنيـاً مستمراً ، ومجهودات متكررة للبحث عن شريك الحياة المتوقع ، فضلاً عن أن عقد الوساطة يفترض أنه يُنفذ على دفعات متوالية أى بطريقة الالتزامات المتتابعة ، حيث يعقب الوفاء بالتزام الوسبط بالبحث التزامات أخرى من التوفيق وإحداث الانسجام بين الأطراف ، لذلك لا يستطيع الوسيط القيام بجميع الالتزامات دفعة واحدة . لكن هذا التتابع الزمنى لتفيذ التزامات الوساطة على دفعات مستقلة ومتوالية ، لا تجعل من فستخ عقد الوسـاطة ذى أثر غير رجعي كـالعقود المستمرة ، إذ أن طبيعة الاستمرار الزمني هنا لا تنقل عقد الوساطة إلى مصاف العقود الزمنية كالإيجار مثثلا، 
بينما نقصد من وصف الوساطة واعتبارها من العقود الذي يمثل فيها الزمن عنصراً

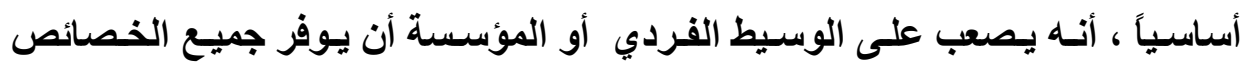

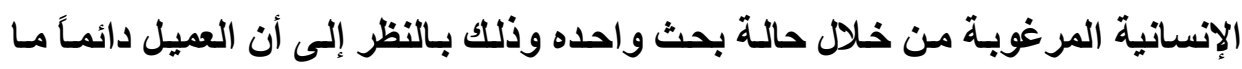

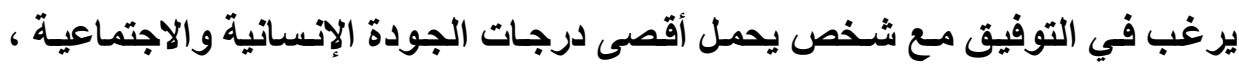

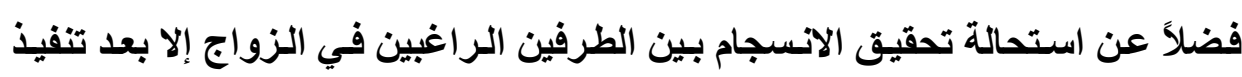

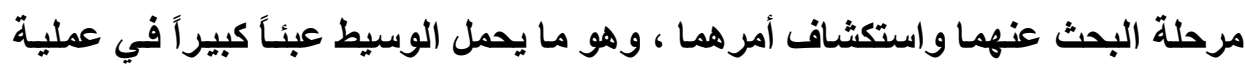

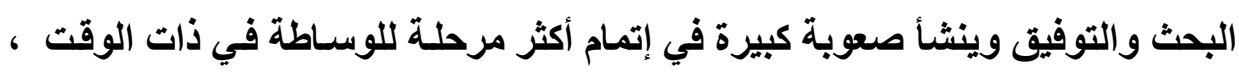

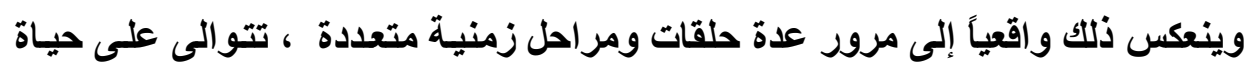

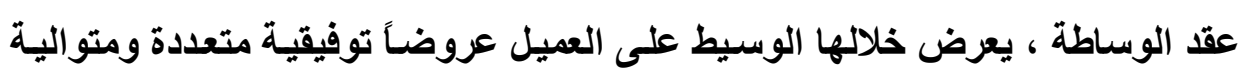

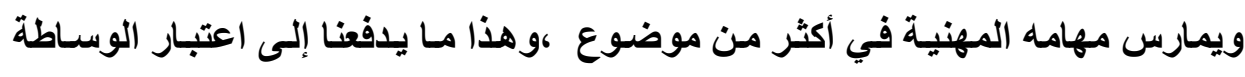

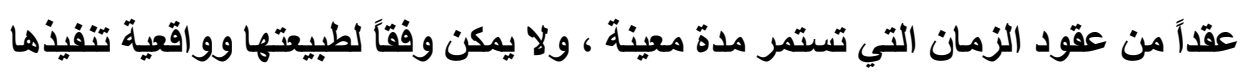

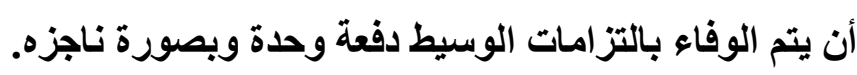
خاهساً: عقد الوساطة ليس هن عقود أو هسائل الأحوال الشخصية. فقد سبق وأن انتهينا إلى أن عقد الوساطة من العقود المدنية غير المُسماة التي

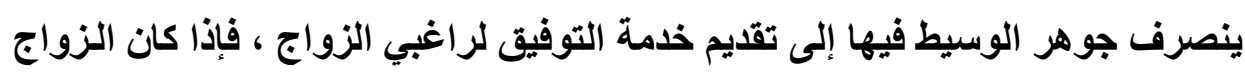

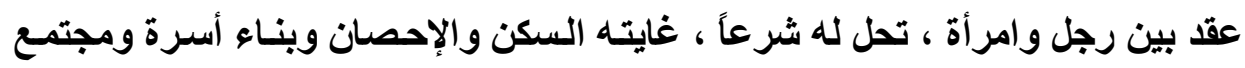

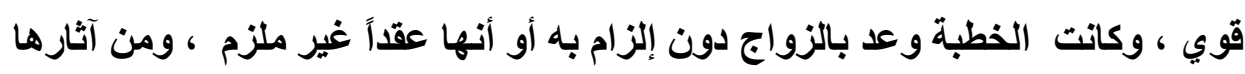

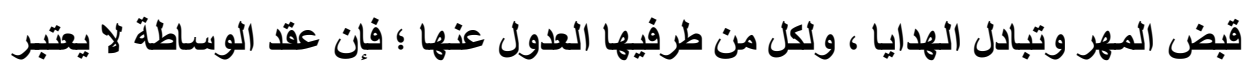

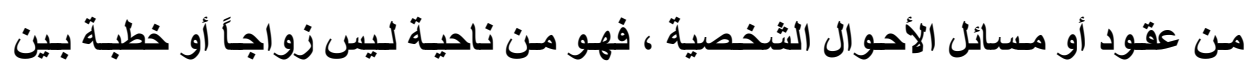

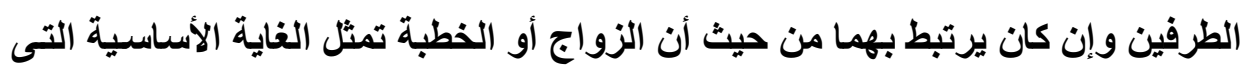
تهدف الوساطة لتحقيقها ، لذلك يمثل الزواج وكذلك الخطبة السبب الدافع إلى إبرام 
عقد الوساطة ويلعب العقد الأخير الدور الذى يوطئ للزواج أو للخطبة بين الطرفين ولا يقع كليهما فى نطاق الالتزامات التى يتعهد الوسيط بإنجازها ، ولا يتحمل فى سبيل تحصيلهما التزاماً سواء كان محله بذل عناية معينة أو تحقيق نتيجة محددة . سادساً: عقد الوساطة عقد غير لازم بالنسبة للعميل يعرف العقد غير اللازم بأنه العقد الصحيح النافذ لكنه يكون غير لازم أي يمكن إنهاء العقد بإرادة أحد طرفيه أو كلاهما بصورة منفردة لا تتوقف على موافقة الطرف الأخر ، وعدم اللزوم أما يكون ناتج عن طبيعة العقد ذاته كعقود الاعتبـارات الشخصية والثقة كالوكالة أوعقود المدة كالعمل والإيجار ، وغيرها من العقود التي يقرر المشرع لأحد طرفيها الحق في إنهائها بإرادته المنفردة ، وقد يرجع عدم اللزوم إلى وجود خيسار لأحد المتعاقدين أو كلاهما بإنهاء العقد دون الرجوع إلى المتعاقد الآخر. وفي الحقيقة فإنـه على الرغم من أن الأصل في العقود هو اللزوم ، فـإن مـا يجعلنا نتبنى فكرة العقد غير اللازم في نظام عقد الوسـاطة هو الارتباط الوثيق بين وسـاطة النكاح وبين الخطبـة الزواج ؛ ذلكـ أن عقد الوسـاطة كالخطبـة لا يلقى ثـة التزاماً على الوسيط بإتمام إبرام الزواج بين الطالبين وسـاطة ؛ لأن الحريـة في الزواج من النظام العام ،لذا فمن غير الجائز أن يقيم العميل فى عقد الوسـاطة دعوى قضائية على عميل الوسيط الآخر مطالباً إياه بإبرام عقد الزواج استناداً لعقد الوسـاطة المبرم من كليهما مع المتوسط بينهما بالتوفيق والخطبة في الشريعة الإسلامية ليست من العقود اللازمـة ، لأنها طلب الرجل الزواج بـامرأة معينـة ، ولا يتحقق بمجرد قبول المخطوبـة أو وليها لهذا الطلب أن تتحول الخطبة لعقد ملزم للزواج ، لا بالنسبة لطرفيها ولا بالنسبة لغيرهم، وسواءأ 
كان هناك مبرر يسوغ العدول أو لم يوجد ، للذلك فبإذا خطب شخصا آخر ذات المخطوبة فعدلت هى عن خطبة الأول وتزوجت بالثاني ، كانت خطبة الأخيرمحرمة لكن زواجه منها يكون صحيحاً. (') ويتوافق اعتبار الوسـاطة عقد غير لازم للعميل مـع مـا تذهب إليه التطبيقات القضائية من تقرير حق العدول للخـاطبين دون قيد أو شرط، فهذا هو المستقر عليه فقهاً وقضاءً بالنسبة إلى الخطبة . () ، وهو ما ينطبق من باب أولى على مفهوم عقد الوساطة ؛ لأنه إذا كانت الخطبة تجسد مرحلة متقدمة عن التوفيق بالوسـاطة ، فهي بمثابة الاتفاق الذي يمها بصورة حقيقية لإنشاء رابطة الزواج التي تعتبر محلاً مباشراً لاتفاق الخاطبين ، بخلاف الوساطة التي تهدف لخلق حالـة من الاتسجام الذي يحتمل أن يفضي أو لايفضى إلى الخطوبة والزواج مجتمعين ، (") ، فإذا كـان الحق فى العدول مقرراً فى الخطبة فيكون أولى أن يتقرر فى الوساطة بوصفها مرحلة أبعد عن الزواج من الخطبة وأقرب فى المفهوم مـن الأخيرة ، لـلك نـرى اقتبـاس هذا الحق المقرر للخاطب فى العدول عن الخطبة ومنــهـ للعميل المتعاقد مـع الوسـيط ؛ وذلك لتشابه

(1) عبد الناصر توفيق العطار،خطبة النساء في الثريعة الإسلامية، مؤسسة البستاني للطباعة،القاهرة . 999 . 1987،

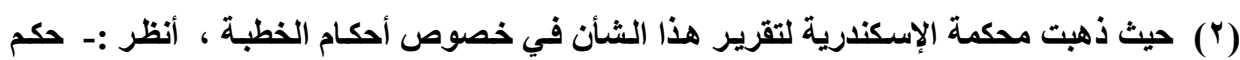

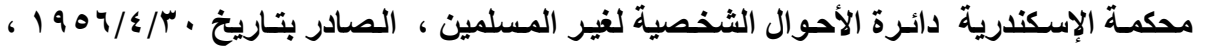

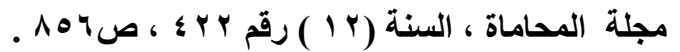

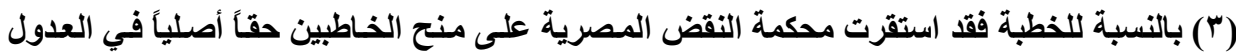
عنها دون قيد أو شرط يقلص من إمكانية الرجوع فيها عن إبرام عقد الزواج .حيث جاء في في قضاء التهاء

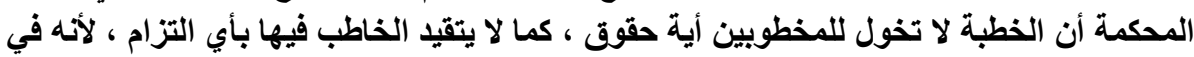

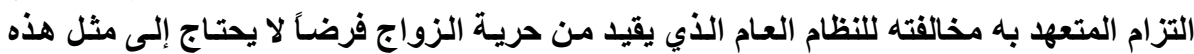


المركز القانوني للخاطب والعميل ، من حيث أن كليهما يبتغي تحقيق غايـة واحدة وهي إنمام الزواج.

والحق فى العدول المُخول للعملاء المتعاقدين مـع الوسيط ، من وجهة نظرنـا ، يعني تراجع العميل وتخليه نهائياً عن مشروع الزواج المستهذف إبرامـه مـع العميل المقابل ، مع وجوب الإفصاح للوسيط عن التوقف التـام عن السير في متابعة الأعمـال والإجراءات المؤدية لتحقيق إبرام الزواج ، وطبيعي ألا ينشأ حق العميل في العدول إلا بعد ما ينعقد عقد الوساطة ويخلق جميع التزاماتـه في ذمـة طرفيهه ، كمـا يتمتـع العميل باستعمال حق العدول في الوقت الذي يشاءه بعد إبرام العقد ، فتحديد الوقت الذي ينبغي فيـه للعميل أن يعدل على استكمال الإجراءات مـن الأمـور التى ترجـع لتقديره الثخصي ولا رقابة للقضاء عليه في ذلك ، فقد يترائى للعميل العدول في مرحلة البحث ، وقد يتخطى العميل هذه المرحلة ليعدل عن استكمال الوسـاطة في مرحلـة التوفيق وإحداث الألفة والانسجام بين الطرفين .

كما يتمتع العميل منفرداً بتقدير السبب الدافع إلى عدوله ، فقد يعزف عن عقد الوساطة لاحتمال فشل الزواج الذي يبتغى إبرامه ، أو لتراجعه نهائياً عن التزاوج من خلال نظام الوساطة ، أو غيره من الأسباب التي يرجع تقدير ها لسلطان العميل الذي يستقل بذلك دون رقابة من المحكمة لمسوغات العدول ، ويترتب على ذلك أن العميل لا يُلزم بالإفصاح للوسيط أو للطرف الآخر عن حقيقة المبررات التي سـاقته لاتخـاذ قرار العدول عن تنفيذ موجبات الوساطة إلى مقتضاها الأي يفرضه العقد ، كما يترتب على استعمال الحق في العدول ، أن الوسبط يلتزم بوقف تنفيذ جميع الالتزامـات الواجبة عليه بمقضتي عقد مع العميل ، وبالتالي يمتنع على الوسيط تداول معلومات العميل بعد العدول ، أو العمل على إحداث الانسجام مـع الطرف الآخر منفرداً ، أو بذل المساعي 
لإقناعه بمواصفات العميل بعد عدوله ، كما لا يجوز عقد جلسات الحوار والتوفيق دون حضور من العميل الذي عدل عن العقد ، ومن ناحية أخرى يجب على العميل إخطار الوسيط بعدوله عن العقد وتراجعه عن المضي لتنفيذه بصورة نهائية ، كمـا لا يؤدي عدول العميل عن العقد إسقاط حق الوسيط فى الأجر . لذلك فمهما ينجم عن عدول العميل عن المضي كطرف في عقد الوسـاطة من مضار ، فإنه لا يكون مسئولاً عنها باعتبار أنه قد استعمل حقاً من حقوقه المخولة لهه ؛ ويرجـع ذلك لأن الزواج وباعتبـاره أسـمي الـروابط الإنسانية ، لذلك فهو يتجرد في حقيقته عـن عقود المعـاملات الماديـة ، وينـصرف لتحقيـق غايـة عظمس مـن البنـاء الاجتماعي الذي يُناط به تحقيق السعادة بين الزوجين وترسيخ ركائز المجتمع الصالح ، ومن ثم فبإن استلاهـام هذه الغايـات ووضـعها موضـع التطبيق في النطاق القـاتوني لا يتحقق إلى بالرضـا الكامل لأطر افه وتجريـ قبولهمـا عن التقيــ المسبق لـه ، لذلك لا يتسنى إجبـار العميل على قبول المضي قدماً إلى تنفيذ متطلبـات الوسـاطة ومراحلها المتواليـة في ظلال عزوفه عن إبرام الزواج ذاتـه ، ويتقرر حق العدول للعميل عن الاستمرار في تنفيذ مقتضيات عقد الوساطة باعتباره من الحقوق المطلقة له ، والتي لا يملك القضاء بشأنها سلطة المراقبة والتقدير ، وينعكس التقرير بحق العميل في العدول لكونه متعلق بالنظام العام على نشوء حقه في العدول كذلك عن تنفيذ جميع التزاماته الناجمة عن عقد الوسـاطة ، عدا الالتزام بـأداء الأجر ، لأن هذا العقد يمثل المرحلة التمهيدية التى تصل بالأطراف لإبرام الزواج ذاته. 


\section{المبحث الثاني \\ التكيسف القانوني للعملاقة الناشئة بين \\ وسطاء التوفيت وراغبي الززواج}

على الـرغم مسن أن مهنـة الموفق بـين راغبـي الـزواج يغلب عليهـا الطـابع

الاجتماعي ، وتتميز كذلك بممارستها في سرية شديدة ، بـالنظر إلى تبني المجتمعـات الشرقية لفطرة رافضة لهذا الأسلوب في البحث عن شريك الزواج ، إلا أن الكيفيـة التي يتلاقي فيهـا الوسـيط براغبـى النكـاح ، ومـا يفرضـه التنفيذ الـواقعي لمراحل البحث والتوفيق من التزامـات عدة تتولد فى ذمـة طرفيها ، ومـا تنطوي عليه طبيعة العلاقة بينهما من بروز ظاهر لاور الإرادة فى إحداث آثنار قاتونية ، مـا دفعنا إلى اعتبار هذا الاتفاق منصرفاً إلى الطبيعة العقدية المحضة ، وذلك من منطلق تضمن العلاقة بين الوسيطوراغب الزواج على مستوى عـال من الصبغة التعاقديـة التي تبرز مـع ازديـاد شأن الإرادة في الاخول في علاقة مع الوسيط ـ و إذا كان من شأن الثوابت المتقدمة أن تصطبغ علاقة التوفيق بـالمفهوم العقدي ، فبان الأمـر يستلزم ولا شـك إنزال التكييف القـانوني الـصحيح على العلاقة التعاقديـة التـي يمكن تصور ها بـين وسـيط التوفيق وعملائه من راغبي الزواج ، مما يستدعي تقسيم هذا المبحث إلى ستة مطالب أساسية ، نجرى فيها مقارنة لبيان أوجه التقارب والاختلاف بين عقد وسـاطة النكاح الشرعي وغيره من الأنظمة العقدية المُسماة والتي تتميز بوجود أصول مشتركة أو تثابه ظاهر بينهـا وبين الوسـاطة التوفيقيـة للزواج ، ممـا يساعد على اسـتجلاء فرصـة إخضاع 
التكييف القانوني لعملية الوساطة الزواجية إلى أى من هذه النماذج العقديـة الشبيهة ، وذلاك على النحو التالي:-

المطلب الأول :- عقد الوساطة في الزواج وعقد العمل. المطلب الثاني:- عقد الوساطة في الزواج وعقد الوكالة. المطلب الثالث:- عقد الوساطة في الزواج وعقد السمسرة. المطلب الرابع :- عقد الوساطة في الزواج وعقد بيع المعلومات. المطلب الخامس:- عقد الوساطة في الزواج والوعد بالعقد والتعهد عن الغير.

\author{
المطلب الأول \\ عقد الوساطة في الزواج وعقد العمل
}

\begin{abstract}
الفرع الأول
أوجه التشابه بين عقد العمل وعقد الوساطة فى الزواج

مـن أجل الوصـول إلى مـدى صـلاحية عقد العمل لتكييف العلاقة بـين وسـيط

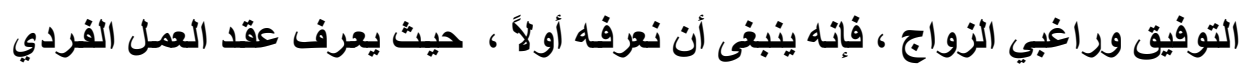

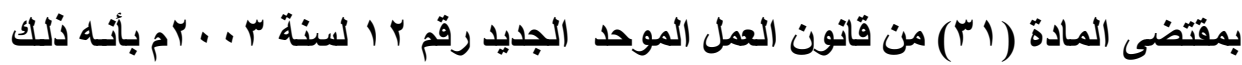

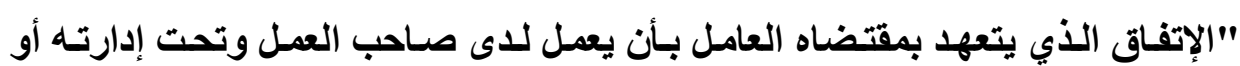
إشر افه لقاء أجر"


ويتكون عقد العمل من منطلق هذا التعريف من ثلاثة عناصر أساسية، وهي

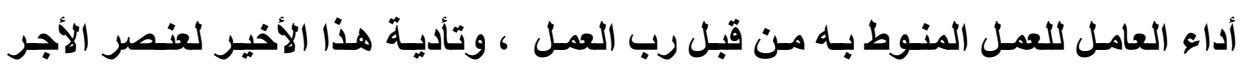

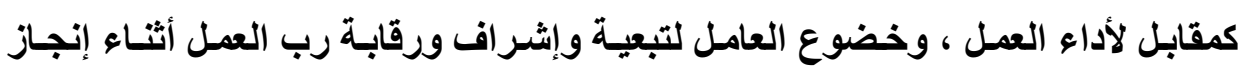

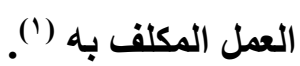

ويحتل عنصر التبعية مكاناً بـارزاً في مجال تمييز عقد العمل عن غيره من

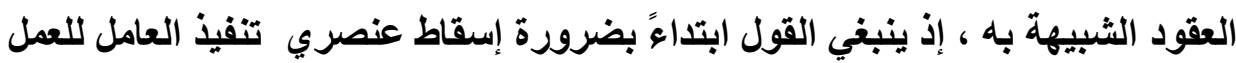

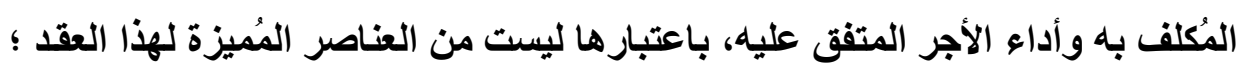

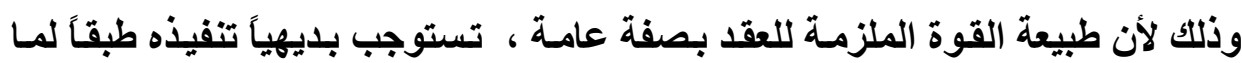

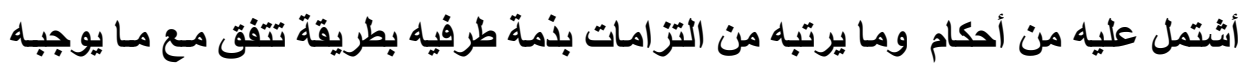
العقد من حسن النية وشرف التعاملات (") .

لذللك وفي سياق المقارنـة بين عقد العمل و العقد المبرم بين وسبط الزواج

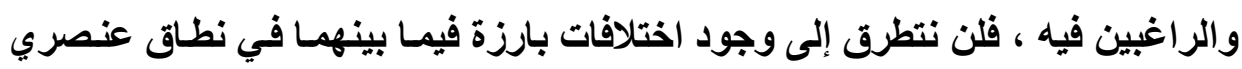

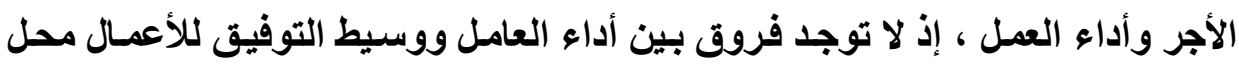

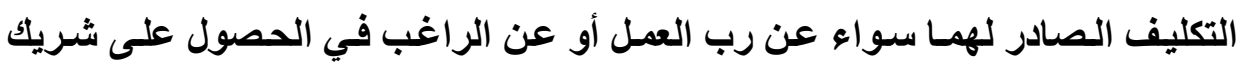

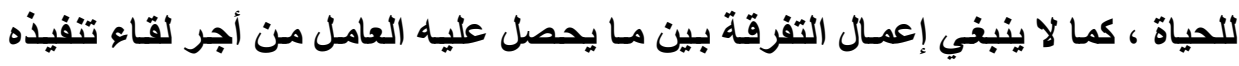

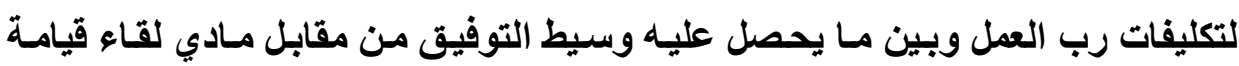

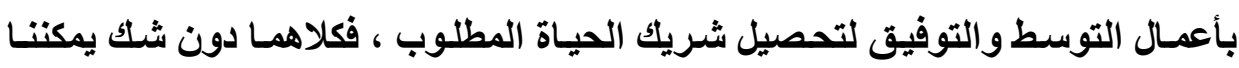

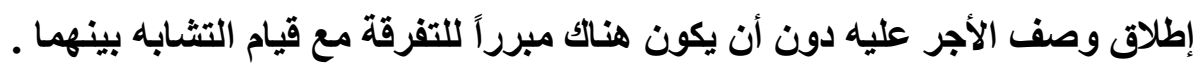

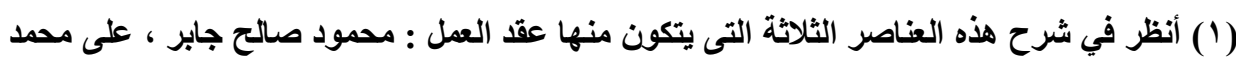

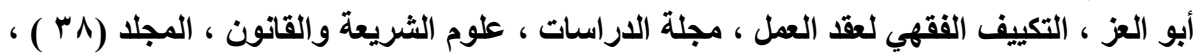

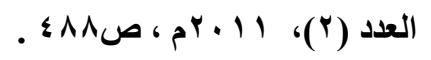

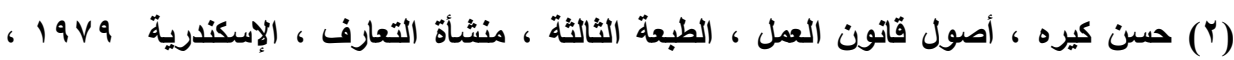

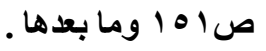


ويضاف إلى ما تقدم من عوامل التقريب بين العقدين ، أن عقد وسـاطة التوفيق يتفق مع عقد العمل في أن كلاهمـا يقوم على عنصر الاعتبـار الشخصي ، فكما أن رب العمل يعول في الغالب على صفات العامل ومهاراته في إنجاز العدل المتفق عليه على الوجه الأكمل ، فبإن طالب الزواج يعتمد كذلك في مسألة اختيـار وسيط التوفيق على سمعته ومهار اته ومعارفه في البحث والتوفيق بينه وبين شريك حياته المتوقع ـ ومن ناحيـة ثانيـة ، فالعقدان يتفقـان في أن كـلا منهمـا يتضمن ضرورة إبرامـه مـع شـص متخصص في مهنته بغرض أداء خدمة معينة تتعلق بتخصصه ، وأخيراً يتثابه العقدان في أن جاتب التنفيذ الزمني فيهما يتم في صورة التنفيذ المتعاقب ، إذ لا يُنفذ العقدين دفعة واحدة بل تستطيل مدة التنفيذ إلى فترة زمنيـة قد تطول أو تقصر حسب طبيعة الأعمال محل التزامات العامل أو وسيط النكاح. بيد أن ما تبقى من العناصر المُميزة لعقد العمل ممـا قد يحول دون الخلط بينه وبين عقد الوساطة للتوفيق بين راغبي الزواج ، هو عنصر التبعية بوصفه العنصر الأهم والمميز الرئيسي بين عقد العمل وعقود أخرى قد تلتبس بـه من عدة وجوه ـ إذ يتمتع رب العمل بسلطة الرقابة والإشر اف من خلال تعليمات يصدرها إلى العامل الذي ينبغي عليه ألا يحيد عنها بوصفها أوامر تحتمل الصفة الإجبارية المُلزمة له('). ورغم هذه الصفة البارزة التى تميز علاقة العمل عن كثير من العقود الشبيهة ، فإن مركز وسيط التوفيق في مواجهة راغبي الزواج يمكن ألا يختلف كثيراً عن ذلك

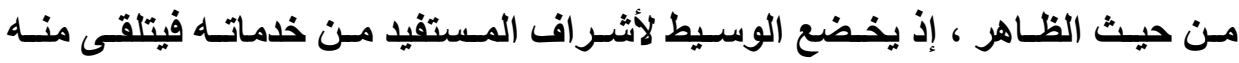
التعليمـات وأوجـه الأشـر اف على الكيفيـة التـي يتحصل بموجبهـا على شـريك مناسب 
للحيـاة، ولا يستطيع الوسيط أن يـتملص مسن التعليمسات المُحددة التـي يصدرها إليـه المستفيد في هذا الشأن ، خاصة أنها ترتبط بمجموعة من المواصفات المرغوبـة في شـريك الحيـاة ، والتي غالبـاً مسا يطرحهـا المستفيد على وسـيط الـزواج في عـداد المواصفات الرئيسية التي تمثل الحد الأدنى من الخصائص المشترطة فيمن يرغب مشاركته الحياة الزوجية ، لذلك يصدر المستفيد بشأنها تعليمسات آمرة للوسبط الذي يتعين عليها ألا يتجاوزها إلا بإذن من العميل ، وفي الغالبية العظمى من حالات التوفيق يلتزم الوسيط بهذه التعليمات بصورة مؤكدة ويبذل في هذا الشأن جهداً كبيراً للحصول على طرف مقابل يتمتع بذات الصفات المُحددة سلفاً من العميل ، بل يرقى التزام الوسيط فى هذا النطاق تحديداً إلى طبيعة الالتزام الذي يجب أن يمخض نتيجة محددة ، ولا يتسنى للوسيط التخلص من المسؤولية عن أداء هذا الالتزام بإثبات بذل العناية الواجبة فحسب.

كما قد يتبادر للأهن أن عقد الوساطة للزواج لا يندرج في عداد عقود العمل لأنه لا يتسم بالديمومة والاستمرار ، لكن ذلك لا يحول دون إنزال التكييف القانوني عليه بوصفه عقداً للعمل إذا كان ذلك يتفق مع جميع الخصائص الكائنـة فيـه ، يؤكد ذلك أن قانون العمل المصري قد أدرج في نطاق عقود العمل الاتفاقات التي تتم مرة واحدة أو في مدى زمني قصير إذا ما كانت طبيعتها تحتم ذلك ، وطالما أنها تتضمن عناصر عقد العمل من الأجر والتبعية(') ، لذلك فإن وصف عقد الوسـاطة للزواج بكونـه علاقة عمل

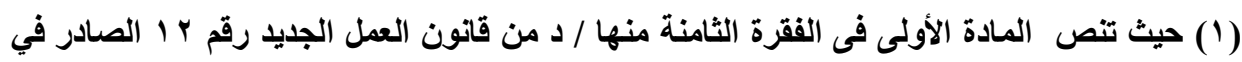

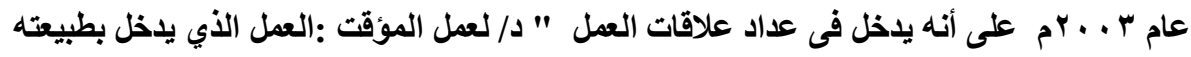

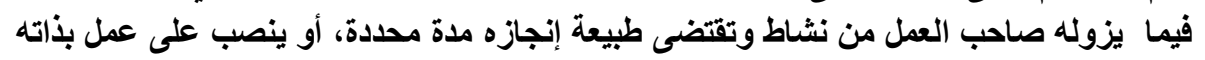

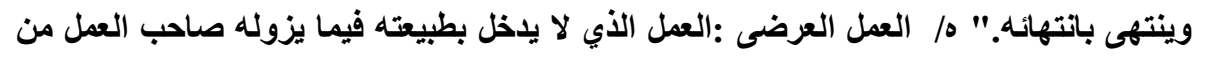
نشاط ولا يستغرق إنجازه أكثر من ستة أشهر." الترضه 
لا يرتفع عنه لمجرد قيام الوسيط بصفقة واحدة لصالح العيل المستفيد أو لأن المدى الزمني لتنفيذ الوساطة والتوفيق قد لا يتسع لمدة طويلـة وفقاً لطبيعة أعمال الوسـاطة في هذا المجال ذو الطبيعة الخاصة ، فجميع هذه الخصوصيات التي ينفرد بها عقد الوساطة لا تجعله بمعزل عن إنزال مفهوم علاقة العمل على التكييف القانوني له . كمـا أن قصور مفهوم التبعيـة العمليـة أو القنيـة في التعبير عن قيـام الرقابـة والإثـراف فـي علاقـة المستفيذ مـع وسـيط الـزوج لا يـشكل عائقـاً دون اعتبـار عقد الوسـاطة مـن عقود العمل كـلكك ، وذلك بـالنظر إلى أن تلك التبعيـة بنوعيهـا العملي والقني وإن كانت تمثل ركناً مهماً فى إثبات علاقة العمل وتكييف وجودها(') ، إلا أنه قد يُقصد بالتبعية فى عقد الوساطة التبعية التنظيمية والإداريـة ، التى تقتصر فيها رقابـة المستفيد على الوسيط في نطاق تحديد الظروف الخاصـة التي يتم فيها تتفيذ عملية التوفيق ، مثل تحديد نطاق البحث الجغرافي عن الزوج المتوقع ، وحصر نطاق البحث في عينـة وظيفيـة مُحددة ، وتعيين الأوقـات المناسبة لمقابلـة الآخر والتعرف عليهه ، وغيرها من أوجه الأشراف التنظيمي على عملية التوفيق والتي لا يشترط فيها أن يقوم راغب الزواج بالإشراف المباشر والمُستمر على الوسيط ، بل يكفي لثبوتها في نطاق علاقة التوسط أن تتوافر مكنة للمستفيد في الرقابـة والتوجيه والإثراف بصورة فعلية على الوسيط ، ويصرف النظر عن حصول هذه التبعية من الناحية الواقعية والتنفيذية. وفي الحقيقة فـإن إنـزال التكييف القـانوني لعقد العـل على علاقـة الوسـيط بالعميل، سوف يؤدي إلى تحقيق مصلحة الوسيط من عدة نـواحي أساسية ، حيث

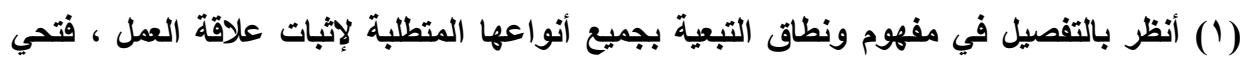

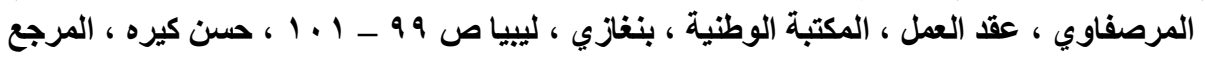

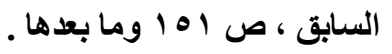


يستحق الوسيط الأجر بمجرد أن يعلن عن الاستعداد للتوفيق بداءًا من الوقت المتفق عليه باعتبار ذلك هو وقت إبرام عقد العمل الذي يقوم معـه الحق في الأجر ، كمـالن يُسأل الوسيط بوصفه عاملاً لاى العميل عن جميع أوجه القصور التعاقدية التي ترجع إلى إخلال المتعاقد بالوفاء بالالتزامات ذات النتيجة المحددة ، إذ تتدرج طبيعة التزاماته

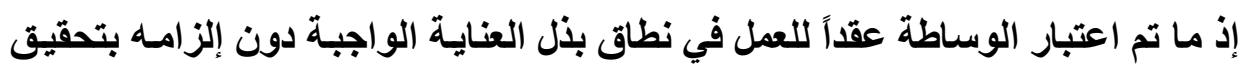

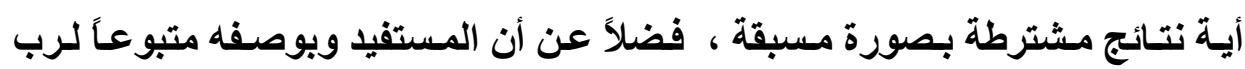
العمل سـوف يتحمل تبعة الأخطاء التي قد يرتكبها الوسبط التـابع لـه أثنـاء ممارسته لأعمال الوساطة والتوفيق ، ويتمتع الوسبط بـلا شك بجميع المزايـا القاتونية الأخرى الناتجة عن إبرام عقد العمل ، مثل استحقاقه لمكافأة نهاية الخدمة وبدل رصيد الأجازات

$$
\text { وغيرها من المزايا. }
$$

\section{الفزءع الثانى}

\section{عدم صلاحية تكييف عقد الوساطة فى الزواج بعقد العهمل}

ولئن كانت التبعيـة تمثنل عنصراً جوهريـاً في عقد العمل ومناطـاً في تكييفهـ

وتمييزه عن غيره من العقود الواردة على عمل الإنسان كالوكالـة والمقاولة ، وعلى الرغم من أن هذا العنصر من التبعية لا يختلف شـأنه الظـاهر كثيراً فى عقد العمل عن أن شأنه فى العلاقة بين الوسيط والعميل كما سبق الإيضاح ، إلا أن تكييف عقد الوسـاطة بغرض الزواج بكونـه عقداً للعمل ووضعه موضع التطبيق هو أمر غير ممكن وذلك

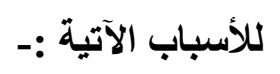




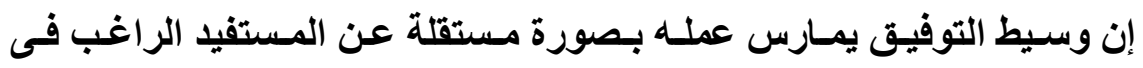

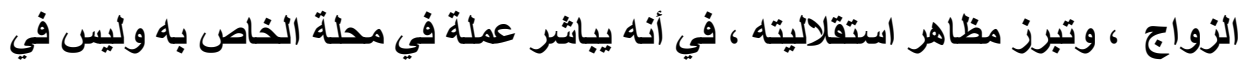

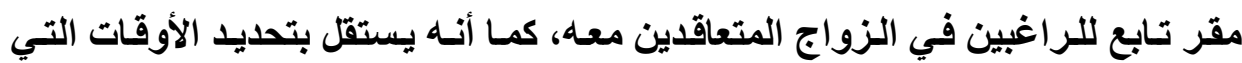

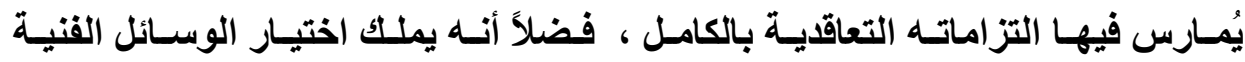
والعلمية التي تسهم في شأن تحصيل الثخصية المرغوب في الارتباط بها ، ومن أبرز مظاهر هذه الاستقلالية أن الوسيط يستعين فى الوفاء بمهمة الوساطة بعمال تابعيين لهـ

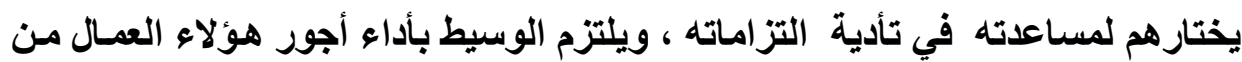

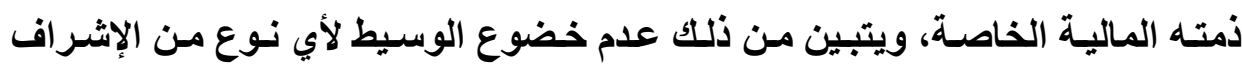

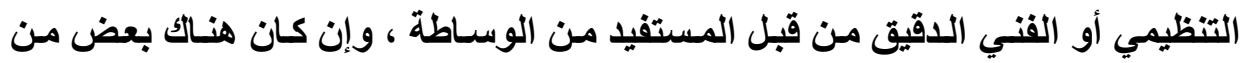

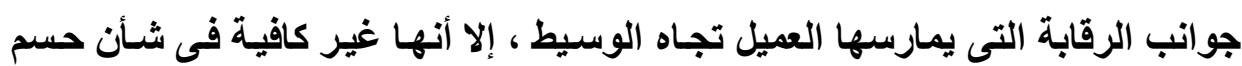

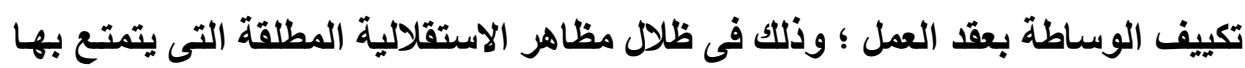
الوسيط فى جوانب أخرى تكـاد تمثل العناصر الأساسية لتنفيذ جميع المسؤوليات

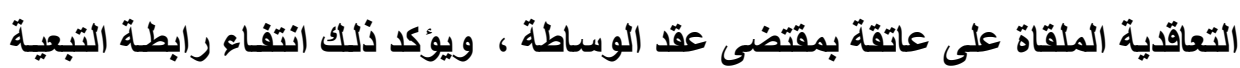

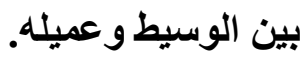

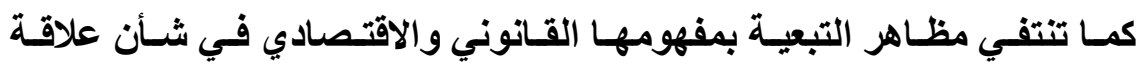

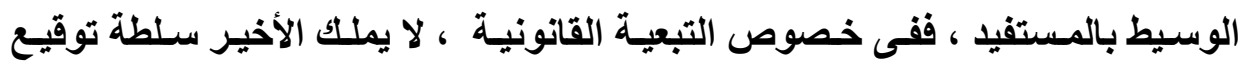

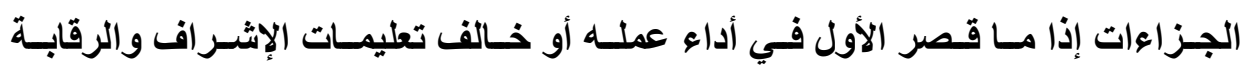
و التوجيه ، فضلاً عن الوسيط يختلف عن العامل الأجير من حيث إن الأخير ملتزم بتنفيذ الأني

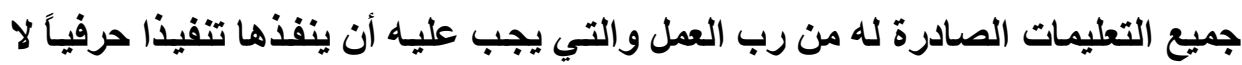
يملك بصدده سلطة التقدير والموازنة ، وعلى نقيض ذلكك فيان وسيط النكاح يتمتع

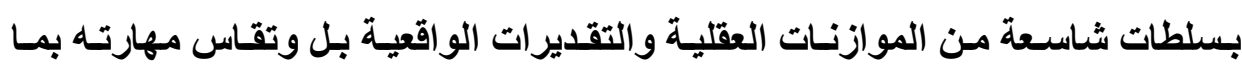

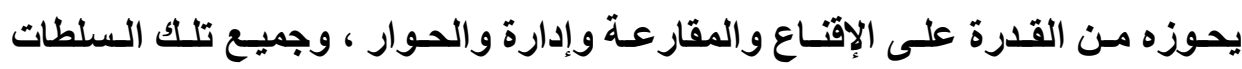
المستقلة تتناقض مع إطلاق وصف التابع على الوسيط . 
وفي خصوص التبعية الاقتصادية بين الوسيطوالمستفيد ، فإنها تباو أيضاً غير

قائمة فيما بينهما ، إذ لا يستأثر راغب الزواج بمجهود الوسبط لقاء أجر يُعد بالنسبة إليه المورد الوحيد لعيثه ، وهنا تختلط التبعية القانونية بالتبعية الاقتصادية ليسهم هذا الخليط في تمييز رابطة التبعية في عقد العمل عن استقلال الوسيط فى عقد الوسـاطة ، وذلك أن معظم العمال الذين يمارسون أعمالهم تحت إشراف وإدارة غيرهم ، لا يعملون إلا لحساب رب عمل واحد (") ، ولا يتقاضون أجورهم لذلك إلا من جهة واحدة ، وهذا الافتراض غير موجود في علاقة الوسيط بالمستفيد ، حيث يعمل الأول بصورة مُحترفة ومن خـلال علاقـات قانونية متعددة مـع عملاء غير محصورين، ويعتمد الوسيط في تحصيل موارده المالية من عدة أثخاص دون أن يهيأ احتياجاته المادية على عميل بمفرده ، كما أن الأجر الأي يتقاضاه الوسيط من العميل يتصف بالتغير وعدم الثبات ، ولا تتحصر عناصر تقديره فى مدى المجهودات التي يبذلها الوسبط بل قد تتحكم فيه عوامل خارجه تتعلق بمدى الملاعة المالية للعميل أو مدى قبول الأخير لشريك الحيـاة المتوقع ، وهذا خلافًا لعقد العمل الذي يُراعى فيه عند تحديد الأجر قدر وطبيعة الأعمـال المنوط بالعامل تنفيذها ، ولا تلعب ملاءة رب العمل ثمة دوراً في تحديد أجر مستخدميه الأي يتسم فى الغالب بالثبات وعدم التغير لمدة مناسبة. ويـقلص مفهـوم التبعيـة الفنيـة كـلك بانتفــاء خـضوع الوسـيط لإشـراف فنـي ينصرف إلى رقابة المستفيد لجوهر الممارسة المهنية التي يقوم بها موفق الرغبات ؛ بحيث يتمكن العميل مع قيام هذه التبعية من الإلمـام بأسرار وطبيعة الأعمـال المهنية

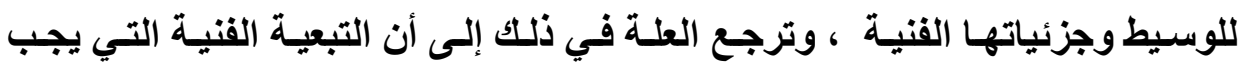
(1) أحمد عبد الكريم أبو شنب ، شروح قانون العمل الجديد ، مكتبة دار الثقافة ، عمان ، ج . بrم ، 
توافرها في علاقات العمل ، تفترض أن يكون رب العمل عالماً بفن الحرفة التي يستقدم لمعاونته فيها عمالاً مأجورين ، وذلك كأثراف المهندسين أو الأطباء على فريق العمال المعاونين لهم في تخصصاتهم المهنية التي يبرعون فيها ، ويشترط هذا المضمون الفنـي إذاً أن يكون رب العمل ملمـاً على الأقل بالتفاصيل الفنيـة التي تؤهله لإخضاع العامل لسلطة الإشراف والتوجيه الفني لطبيعة الإعمال الموكولة إليه (")، ولا يمكنتـا بطبيعة الحال القول بأن الراغب في الزواج يمتلك فرضاً لجميع المهارات التي يتمتع بها وسبط التوفيق خاصـة قراتـه الفائقة في البحث والإقنـاع والتوفيق ببين راغبي الانكحة الثرعية ، خلافاً لما يحوزه الوسيط من قائمة هائلة لبيانات ومعلومات مُخزنـة لايه عن طوائف متباينة لأشخاص يرغبون في الحصول على شريك الحياة المناسب ، وفي ظلال هذا الاختلاف الفني في إمكانـات المستفيد في مواجهة الوسيط يضحى من غير الملائم إطلاق مفهوم التبعية القنية للوسيط في علاقة بالعملاء الراغبين فى النكاح.

\section{الإطلب الثاني \\ عقد الوساطة فى الزوفاج وعقد الوكالة}

يتولى وسيط التوفيق إعمال مهارات البحث لايه عن شريك الحياة المطلوب بناءً على تفويض يـصدر لـه عن الراغب في الززواج الـذي يقوم بـدوره بإمـداد الوسـيط بالمعلومات الأساسية عنه وبالخصائص الجوهرية المرغوب توافرهـا في طرف النكاح المقابل ، لذلك ينصرف جوهر العلاقة بين الوسيطوالعميل فى أن الأخير يفوض الأول

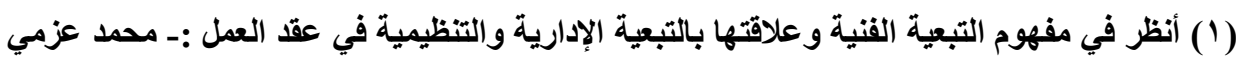

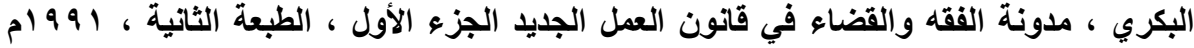

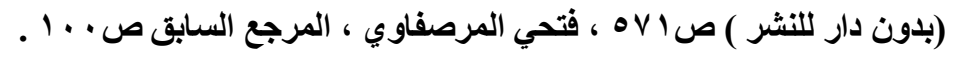


في مرحلـة البحـث والاستكشـاف عن شـخص غير معلـوم ذو صـفات معينـة أو قابلـة

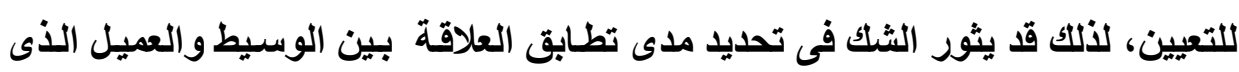
فوضه وبين علاقة الوكيل بموكلة ، بما يترتب على ذلك من نتائج يمخضها هذا التكييف من حيث تنظيم العلاقة بين طرفي عقد الوساطة وتحديد التزامسات أطرافها والمسؤولية الناتجة عن الإخلال بها .

ومن الخصائص التي تجمع بين وسـاطة الزواج وعقد الوكالة ، أن كليهما من

عقود الاعتبـار الشخصي التي تقوم على الثقة في شـص المتعاقد الآخر ، فكمـا أن

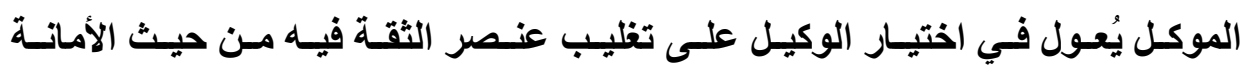

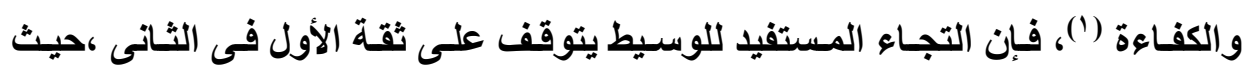
يؤتمن الوسيط على أسرار العميل الثخصية وخصائصه الأتية التي قد يحرص على عدم الإفضاء بها لأقرب المقربين إليه ، فضلاً عن تماثل العقدين ، الوسـاطة والوكالة ، في كونهما عقدين غير لازمين() ، من حيث أن المشرع قد منح الموكل سلطة العزل ومنح الوكيل حق التنحي ، هذا ما يبدو مقرراً بطبيعة الحال في عقد الوساطة للتزويج ، وذلك لاتحاد العلة بينه وبين عقد الوكالة ، إذ أن طبيعة هذه العقود وما تضمنته من قيام أحد طرفيها بتنفيذ عمل بالنيابة عن شخص آخر فوضه في التعبير عن إرادته ، يضاف

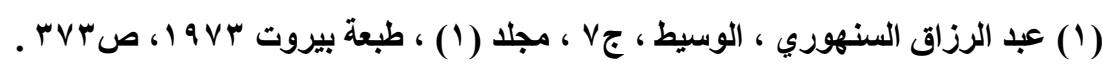

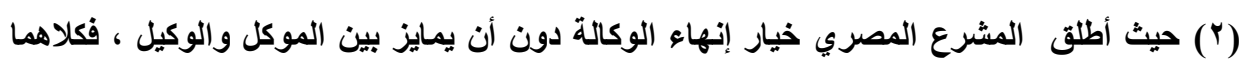

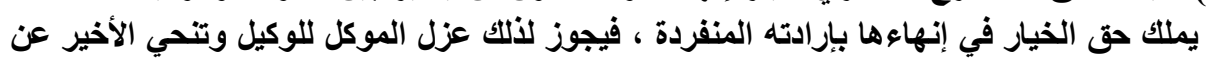

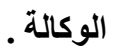

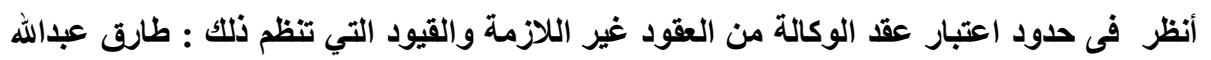

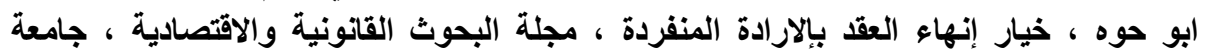

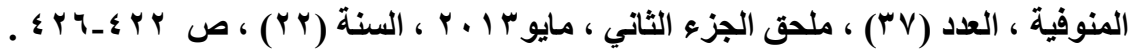


لألك قيامها على عنصر الاعتبار الثخصي والثقة ، لذلك فبإن كل مـا يؤدي إلى اختلال الثقة بين طرفيها يـفع إلى القول بضرورة وضـع حداً لسريانها بإرادة أحد طرفيها بواسطة خيار فردي يمثل ميزة منحها المشرع لأحد عاقديها أو لكليهما . ويتمادى التثابه بين العقدين ، الوكالة والوسـاطة في الزواج ، في أن كليهـا يلقى على عاتق الطرف المكلف تنفيذ الالتزام المفوض في التزامـاً بالسرية فيما يقع

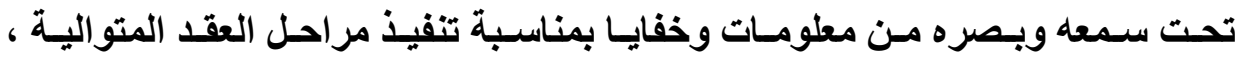
والتزاماً آخر بالتبصير والأعلام ، حيث يلتزم الوسيط بتبصير طالب البحث عن شريك وإمـداده بالمعلومسات والحالـة التي وصـل إليهـا في مفاوضـات البحث ، هـا هـ ذات الالتزام الذي ينبثق عن عقد الوكالـة ويُلقى على عـاتق الوكيل واجب إخبار الموكل واطلاعه على المعلومات اللازمة بخصوص المرحلة التي توصل إليها بصدد تنفيذه مـا وكلـه فيـه ، نـاهيك عمـا يجمـع بـين العقدين مـن ثبـوت الاسـتقلالية التنفيذيـة للموكل والوسبط لاتجاز الأعمال المكلفين بها. بيـ أن أوجـه التماثل بين الوكالـة والوسـاطة في الززواج ، لا تصلح رغم أنهـا قاربت بينهمـا ، في تكييف الوسـاطة واعتبارهـا وكالة صدرت عن المستفيل مفوضساً بموجبها الوسيط في البحث عن شريك الحياة المتوقع ، حيث توجد بينهمـا من الفوارق الجوهريـة التـي تشكل مانعـاً يحـول دون إسـقاط أحكـام الوكالـة وتطبيقهـا في علاقـة التوفيق لإبرام زواج احتمالي . ويتمثل هذا المـانع الذى يحول دون تلاقي الوكالـة وعقد الوسـاطة ، فـى أن الطرف الراغب في البحث عن شريك الحياة لا يبرم عقد الوساطة بغرض توكيل الوسبط في إبرام عقد الزواج ذاته إنما يطلب فقط البحث والمفاوضة بغرض التوفيق بينه وبين 
طرف آخر يحمل الخصائص الذاتيـة والصفات التي تروق للمتعاقد مـع الوسيط ، لذلك ينحصر دور الوسيط في التوفيق بغرض إبرام عقد الزواج ، ولا يمتد دوره إلى إبرام عقد الزواج بالفعل ، لأنسه ليس وكيلاً عن المستفيد في إبرام هذا العقد الشرعى ، ويتحدد جوهر التزام الوسيط في إنجاز المفاوضات التي توفق بين طرفين راغبين في إبرام عقد الزواج ، وهى بطبيعتها أعمـال مادية لا ترقى إلا درجة التصرف القانوني الذى يمثل محلاً لالتزامات الوكيل الذى يقوم بإبرام التصرفات القانونيـة لصساب موكله وينصرف أثر التصرف للموكل لا للوكيل (')، وهذا بخلاف الوسـاطة التى يمسارس فيها الوسيط أعمالاً مادية ولا يبرم بصددها تصرفات قانونية لحساب العميل. إذاً لا يشكل إبرام عقد الزواج التزاماً على الوسيط يفرضه عليه عقد الوسـاطة ، ولا يكون الوسيط طرفاً فى عقد الزواج ذاته لأنه ليس ولياً شرعياً عن الزوجة وليس وكيلاً عن الزوج فى التعاقد وإبرام عقد الزواج ؛ لذلك فإن علاقة الوسبط بالر اغب في الزواج تنتهي بمجرد التوفيق بينه وبين الطرف الآخر، شريطة أن تتناسب خصائص الأخير مع توقعات العميل في شريك الحياة ، لتبدأ مرحلة جديدة لإبرام عقد الزواج وهى

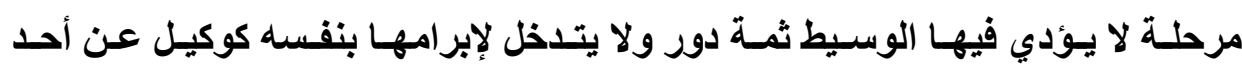




\section{الامطلب الثالث}

\section{عقد الوساطة فى الزواج وعقد السـمسرة}

\section{الفرع الأول \\ أوجه التشابه بين عقد السسمسرة وعقد الوساطة}

تعتبر السمسرة مـن العقـود الشائعة في المجـالات التجاريـة نظراً لمـا يقدمـهـ

السمسار مـن خـمات جليلـة على المستويين المحلـي واللدولي ، فقد ينشخل التـاجر

بأعماله وقد لا تتسع خبراته للبحث عن متعاقد يبرم معه صفقة تجاريـة مـا ، فيستعين في كثير من الأحيان بطائفة من الأشخاص الذين يبرعون في تصريف أمور تجاريـة فيطلب منهم التوسط لصالحه لاى آخرين من التجـار أو العمـلاء لإبرام عقد من العقود التجارية أو المدنية في مقابل أجر يحصل عليه السمسار (').

ولقد تعددت تعريفات عقد السمسرة ، فيعرفه البعض بأنسه " العقد الذي يلزم بمقتضاه شخص يدعى السمسار من قبل شخص آخر يسمى مصدر الأمر أو مفوض السمسار بإيجاد متعاقد لإبرام صفقة معينة مقابل أجر " (†) ويعرفه البعض الأخر بأنـه " العقد الذي يلتزم بمقتضاه السمسار نظير عمولـة معينـة يتقاضـها من عملية ، إمـا

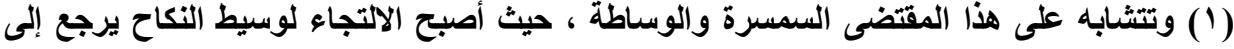

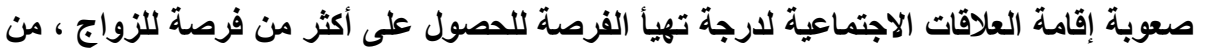

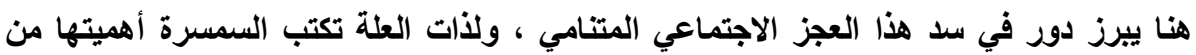

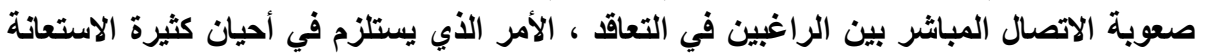

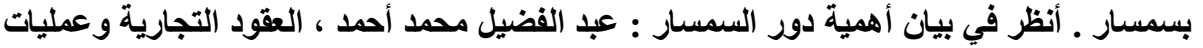

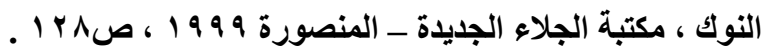

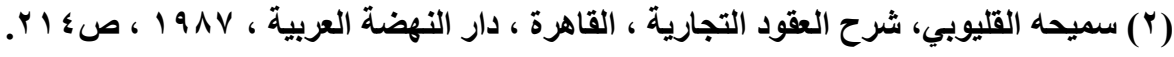


بالعثور على شخص يرتضي التعاقد مع العميل ، و إمـا بإقـاع شخص معين عن طريق التفاوض بالتعاقد مع هذا العميد (') ـ أما القانون المصري فلقد تناول تعريف السمسرة في المـادة ب 9 ا مـن قـانون التجـارة بأنـه " عقد يتعهد بمقتضاه السمسار الشخص بالبحث عن طرف ثاني للإبرام عقد معين والتوسط في إبرامه " ويتبين من هذه التعريفات أن مهمة السمسار تنحصر في التقريب بين شخصين لأجـل التوسـط لإبـرام عقــ معين مقابـل أجر متفق عليـه ، وهـو يعـل لانجـاز مهــة الوسـاطة دون أن يكون تابعـاً لأي مـن أطراف العقد أو الصفقة المرغوب إتمامهـا ، بمعنى أن السمسار لا يرتبط بعلاقة عمل مع من يفوضه لأنه ليس تابعاً له و إنما يمارس

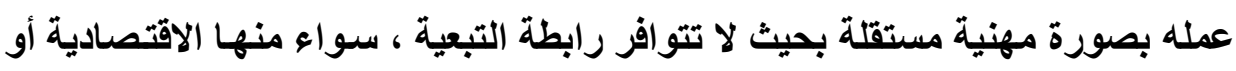
القانونية ، بينه وبين من فوضه في البحث والتوسط.

وعلى هذا المقتضى يبدو أن أوجه التقارب بين العقدين ، السمسرة والوسـاطة بين راغبي الزواج ، أمراً محسوماً بحيث قد يتصور البعض لأول وهله أنه من الصعوبة بمكان الحديث عن وجود أيـة فوارق بينهمـا ، حيث يتوسط موفق الزواج بين عملائهـ الراغبين في البحث عن شريك الحياة المحتمل ويسعى إلى التوفيق بينهما توصلاً لإبرام عقد الزواج الذي يمثل الغايـة المستهدفه من تفويضه في مهمـة البحث عن الطرف الآخر والتقريب بينه وبين مصدر الأمر للموفق ، وذلك لقاء أجر متفق عليه بينهما . فضلاً عمـا يثير الخلط بينهما من حيث إن مهمة السمسار تقتصر في الأصل على البحث والتوسط بين شخصين يرغبـان في التعاقد ، دون أن يكون طرفاً ثانياً في 
العقد الذي يتوسط لإبرامه (')، وهذه الحدود هي ذات يجب أن يقوم به موفق الزواج في نطاق مهمة البحث عن شريك الحياة ، حيث تتوقف مهمته عند حدود البحث والتوفيق ولا يتصور أن يكون طرفاً في علاقة الزواج المتوقع إبرامها بين الطرف الذي فوضها

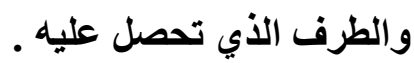

ويثترك العقدين كنلك ، في كونها عقدين غير لازمين لأطرافها ، فمن ناحية أولى ، فإذا كان يحق للعميل أن يززل السمسار في الوقت الذي يريده قبل تنفيذ عقد فئد

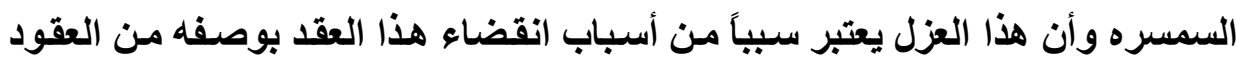

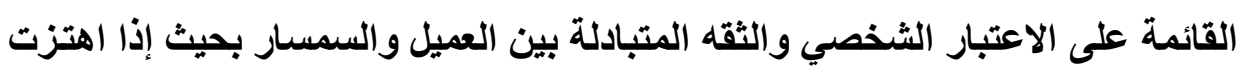
الثقه لاى العميل ، جاز له أن يعزل السمسار بإرادته المنفردة ، لينقضي العقد بينهما بالعزل(") ، كنلك فإنه وبالنظر إلى قيام عقد الوسـاطة للبحث عن شريك الحياة الآخر على اعتبارات من السرية والخصوصية في تداول المطلومـات ومـا ينتج عن ذلكك من فئن قيـام الثقة للاى العميل في أمانـه وكفـاءة الوسيط عند ممارسته مهام البحث ، فبإذا انتزعت هذه الثقة وثثارت لاى العميل شكوكاً حول الأمانة التي استودعها في الوسيط التيط

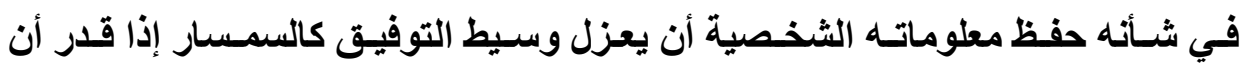
مصلحته لم تعد قُائمة معه. (")

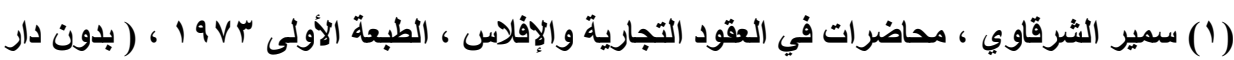

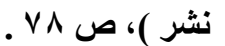

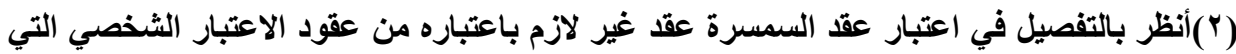

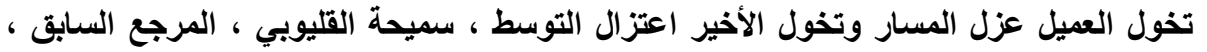

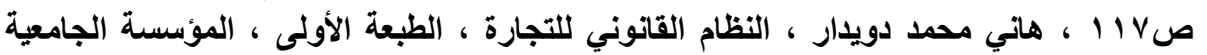

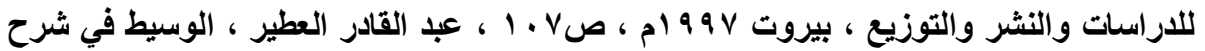

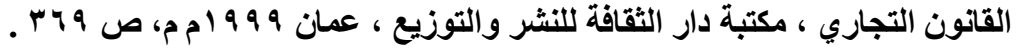

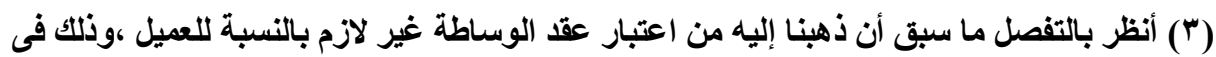
الفرع الثانى من المطلب الثانى من المبحث الأول.

مجلة البحوث القانونيت والإقتصاديت 
بيــ أنـه إذا كانت الروابط الايجابيـة تشكل جوامـع مباشـرة تقيم الصلة وتثبـت الثبه بين السمسرة والوساطة بين راغبي الزواج ، فهناك أيضاً عوامل غير مباشرة تجمع بين العقدين وتأتي كنتيجة لاتحادهمـا في طبيعة الأعمـال الماديـة المحضة التى يتـولى الوسـيط تنفيـذ الوفـاء بهـا ، فالسمسرة والوسـاطة في الـزواج ، تتحـدان في اختلافهما عن الوكالة بصفة عامة ، لأن الأخيرة ينوب فيها الوكيل عن أحد طرفي العقد في إبرامه والتوقيع عليه ، أما السمسار والوسيط فينحصر عمل كل منهما على التقريب بين وجهتي نظرا طرفي التعاقد بغرض إبرامـه دون أن يكون أحدهما نائباً في الإبرام والتوقيع عن المتعاقــ الأصسيل ،لـلتك يجمـع بـين السمسرة ووسـاطة الـزواج أنهمـا ينصرفان فى الغالب إلى القيـام بعدل ذو طبيعة ماديـة محضة( ) ) ،يتمثل في إيجـاد الصلة بين من يرغبان في التعاقد ، سواء أكسان العقد المطلوب إبرامسه عقداً ماليـاً أو عقداً شرعياً ، ففي الحالتين يعمل كل منهما على التقريب بين عرض أحدهما وطلب الآخر حتى يلتقيان معاً ، وتتحدد إرادتهما وييرمان عقدهما الذي يجسد محلاً لوسـاطة كل من السمسار ووسيط النكاح. وهكذا تختلف السمسرة ووسـاطة الزواج عن الوكالـة التي يكون محلها قيسام الوكيل بعمل قانوني لحساب الموكل على أن يكون ملزماً له بكل آثارة ، بينها في عقدي السمسرة والوساطة يتم تكليف السمسارة والوسيط القيام بعمل مادي تُعرض نتائجه في النهايـة على المفوض لكليهمـا ليتسنى لهـذا الأخير التعاقد باسـمه ولحسـاب نفسه ، فالسمسار ووسيط الزواج يمـثلان نوعـان من الوسـاطة القائمسة على الاستقلال التـام

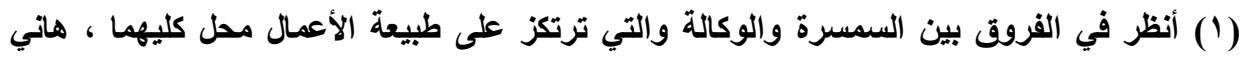

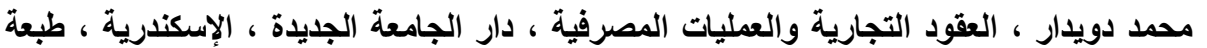

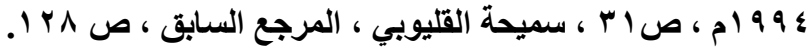

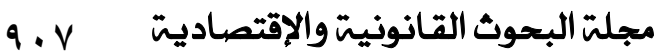


للشخص المهني القائم عليها ، بينما الوكالة عمل يقوم على فكرة النيابة في التعاقد ، وعليه فإن عمل السمسار ووسيط الزواج ينتهي بمجرد تلاقي طرفي التعاقد عند لحظة

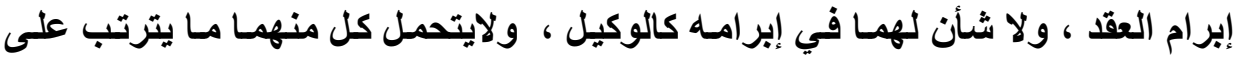

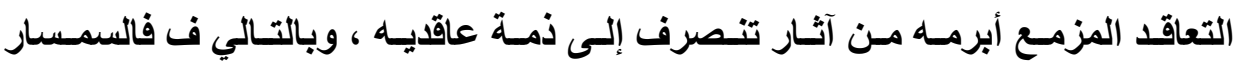
والوسيط لا يتحملان أدنى مخاطر للصفقات أو لعقود الزواج التي يتوسطا لإبرامها ـ (')

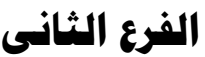

\section{عدم صلاحية عقد السمسرة لتكيفيف العلاقة بين}

\section{وسيط النكاح وراغب الرزواج}

وعلى الرغم من هذا التشابه الكبير الذي يهيمن على طبيعة المهمـة التي يُنـاط بها السمسار وموفق الزواج ، وما يؤدى إليه من ضرورة إنزال الأحكام القانونية لعقد السمسرة وجعلها موضوع التطبيق في العلاقة بين موفق الزواج وعملائسه ، إلا أنـه. وبتمحيص الأحكام القانونية التي انتظمها المشرع المصري بشأن أعمـال السمسار والتزاماته ، فإنتا نرى من جانبنا ، أنه لا يمكن تطبيق أحكام عقد السمسرة في مجال التوسط لإبرام عقد الزواج ، وذلك للأسباب الآتية :

(1) وعلى الرغم من وضوح الفارق بين الوكالة والسمسرة ، إلا أنه يلاحظ وجود خلطاً كبيراً بينهما

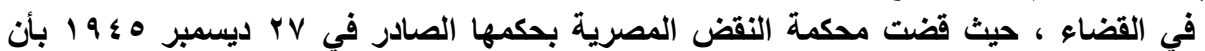

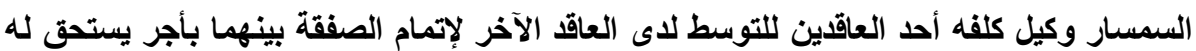

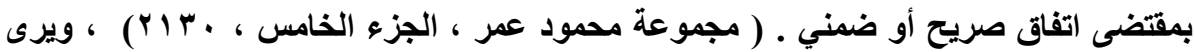

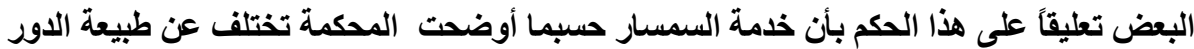

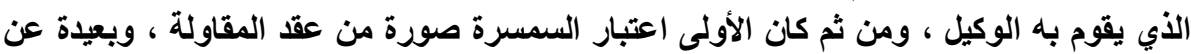

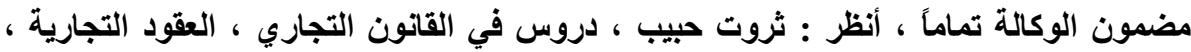

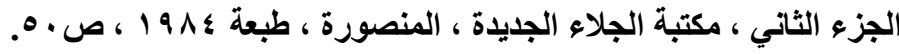




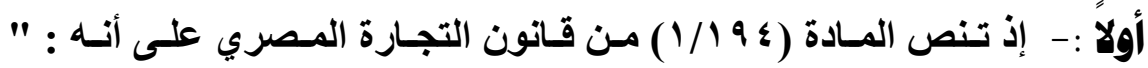
ا ـ لا يستحق السمسار أجره إذا أدت وساطته إلى إبرام العقد ، وإذا لم يتم إبرام العقد

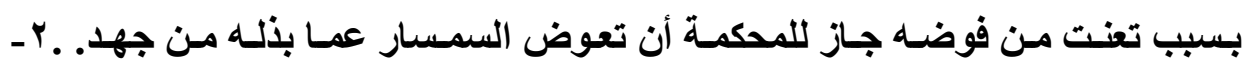
يستحق السمسار الأجر بمجرد إبرام العقد ولو لم ينفذ كله أو بعده ." ويتبين من هذا النص أن استحقاق السمسار لأجره يكون متوقفاً على نجاحه في مسعاه وذلك بإتمام الصفقة التي فوضه العميل في التوفيق والسعي لإتمامها ، وقد حدد

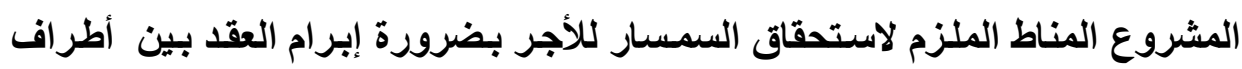
الصفقة ولو تم إبرامه في صورة عقد ابتدائي ، كما فرق المشرع بين إبرام العقد وبين تتفيذه تنفيذاً كلياً أو جزئياً ، فقرر منح السمسار مقابل مسعاه بمجرد النجاح في مرحلة إبرام وبصرف النظر عن تنفيذه من عدمه ، وأخيراً فإن السمسار لا يستحق الأجر إذا كان العقد الذي توسط لإبرامـه معلقًا انعقـاده على شرط واقف ، ويحق تقاضسي أجره كاملاً بمجرد تحقق هذا الثرط (م ـ 1 / /\%) من قانون التجارة المصري (1) . ولا شــك فبإن قواعد اسـتحقاق السمسسار للأجر لا تنطبق برمتهـا على مقابـل المجهودات التي يبذلها وسيط التوفيق بين راغبي النكاح، فـالتزام العميل بـأداء الأجر يقوم بمجرد نجـاح الوسبط في تقديم شخص يتمتـع بالخصائص والبيانـات المرغوبـة

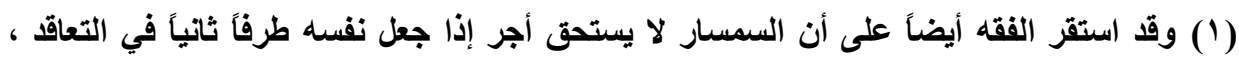

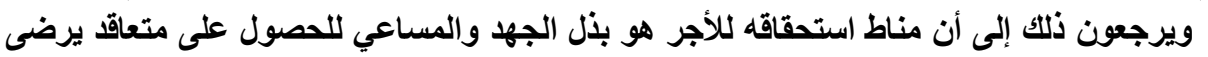

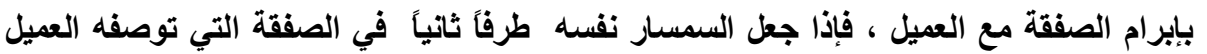

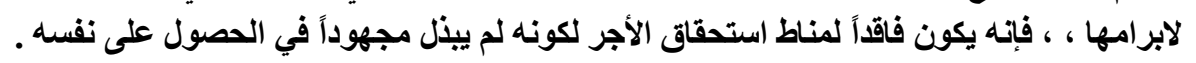

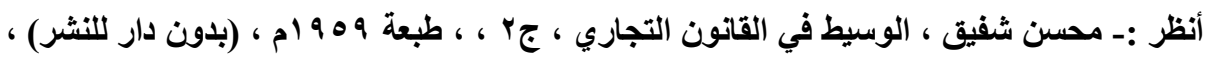

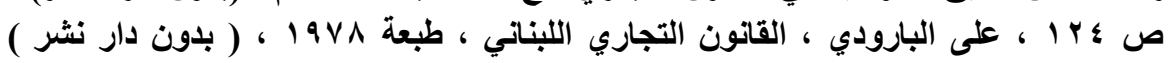

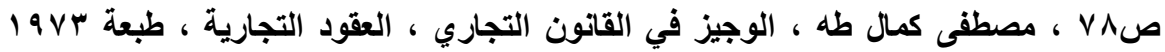

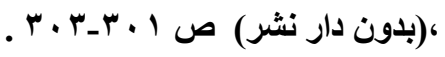


للزواج ، دون أن يتراخى استحقاق الأجر لإتمام الصفقة كمـا في نظـام السمسرة ، ولا يستطيع العمبل التنصل من أداء الأجر بدعوى أن استحقاقه لا بـ وأن يتزامن مع إبرام الزواج بين الطرفين ؛ ويرجع ذلك لأن إتمام عقد الزواج ليس من الالتزامسات التي تقع على عـاتق الوسيط ، باعتبار هـا الحلقة التي يتأخر تنفيذها إلى مـا بعد انتهاء جميع الالتزامات الناشئة عن عقد الوساطة فوسيط النكاح ينتهي دوره عند تحقق القبول للى كل من طرفي العلاقة بخصائص وصفات الطرف الآخر ، وعندئذ يستحق الوسبط أجره بالكامل لوفائه بما يفرضه طبيعة الدور التعاقدي لممارسته المهنية .

ثانياً: - عقد السمرة عقد غير لازم للسمسار والعميل على حد سواء ، بينمـا عقد الوساطة غير لازم للعميل فقط على الوجه الذى أوضحاناه سلفاً عند بيان خصائص لأل عقد الوساطة ، فضلاً عن أن محل إعمال السمسار يكون إبرام صفقات مالية تجاريـة ومدنية ، بينما لا يتوائم مع سمو علاقة الزواج والخطبة التى يستهدفها عقد الوسـاطة أن يكون محلها أو أن يمكن أعتبارها صفقة مالية أو تجارية .

ثالثـاً :- ومـن حيث طبيعة الالتزام الأسساسي الذي تقوم عليهه كل من فكرتـي السمسرة ووساطة الزواج ، فإنتا نرى من جانبنا أن هناك فرق جوهري بينهمـا ، وذلك من ناحية أن طبيعة التزام السمسار تتحدد ببذل عنايـة الرجل المعتـاد في قيامـه بعمله وتقاس ذلك فيه باعتباره مهني متبصر يتمتع بالاحتراف والحسن في طائفة السماسرة في مجال التعاقد المطلوب( () ، ويكون المعيار الذي يحكم تقدير مدى قيامسه بالوفـاء بالالتزام هو سلوك التاجر المعتـاد من أفراد مهنته ، وفي مثل ظروفه وتطبيقاً لذلك ، يلتزم السمسار بالقيسام بالعمل المعهود إليهه ومقتضاه أن يحضر لعمليه ، لكن طبيعة

(1) بروت حبيب ، المرجع السابق ، صזه . 
التزامات الوسيط تكون متغيرة على نحو ما سنرى لاحقاً ، فتكون التزاماتـه فى نطاق عملية البحث ذات طبيعة يمكن تحصيلها ببذل عنايـة ، أمسا فى نطاق الالتزام بإيجـاد شريك حيـاة ذو خصائص معينة فلا يمكن تحصيلها إلا بتحقيق نتيجة معينة يرغبها العميل فى زوج المستقبل المتوقع .

رابعـاً: :- كمـا نعتقد أن مسئولية السمسار عن الإفصاح عن مستويات نجـاح الصفقة تتسع لاستيعاب التزامات عدة يجب عليه الوفاء بها ، فالمشرع المصري أوجب على السمسسار الالتزام بعرض الصفقة على العميل والمتعاقد للآخر بـصورة تتسع لأقصى درجة ممكنة مـن المصداقية ، فـلا يقتصر التزامسه على إمداد العميل بظروف الصفة أو تقصى أهليه المتعاقد معه واحتمالات نجاحها فحسب ، بينما ينصرف الالتزام بـالإعلان إلى إحالـة العميل بـاحتمـالات خسارة الصفقة ومـا يلابسها مـن إثـكاليات قانونية أو تجارية ويتحمل السمسار مسؤولية الخطأ فى ذلك ( 1) وفي المقابل لا يتعدى دور موفق الزواج إلى هذا النوع من المسئولية ، فيؤدي بذلك التزامـه بـالتوفيق في نطاق إخبار العميل بالمعلومات والبيانـات الجوهريـة دون أن يلتزم بالإفصاح عن رأيسه الشخصي المجرد في تقييم الطرف الأخر ، ودون أن تستطيل مسئوليته لذات المدى

والتفاصيل الدقيقة التى يلتزم السمسار تزويد عملاءه بها .

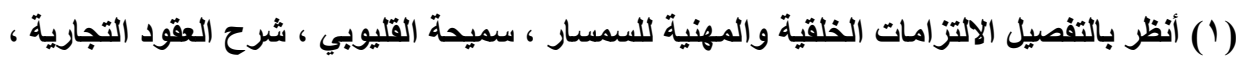

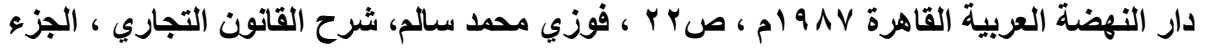

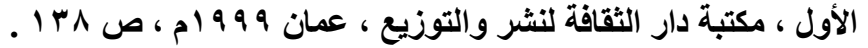




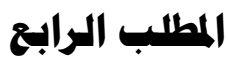

\section{عقد الوساطة في الزواج وعقد بيع المعلوهات}

إن مـا قد يقيم الصلة بين الوسـاطة وعقد بيع المعلومـات ، أن العقد الأخير

يتضمن نقل ملكية المعلومات بحيث يتظلى عنها البائع بصورة نهائية لتؤول ملكيتها للمشتري بما يخوله التصرف فيها دون قيود ، حيث إن مفهوم الدحل في عقد البيع لم

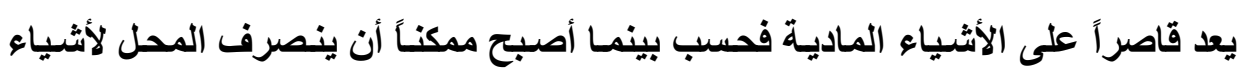
معنوية لا تدرك بالحواس المادية ولذلك لا يوجد ما يمنع من أن تكون المعلومات محلاً لعقد البيع (')

ولإبرام عقد الوسـاطة يتحصل العميل من الوسيط على معلومـات مهمة تتعلق

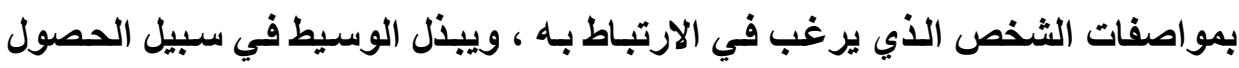

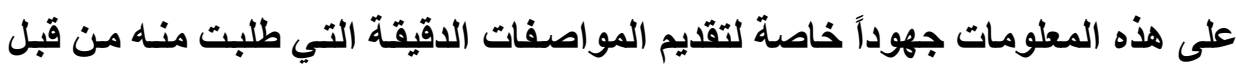
المتعاقد معه ، ومن ثم فقد يثور فى الاعتقاد أن العلاقة المبرمة بين الطرفين هي عقد

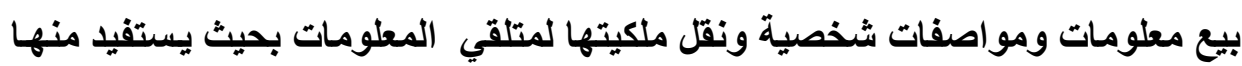

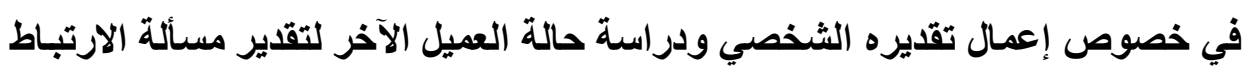

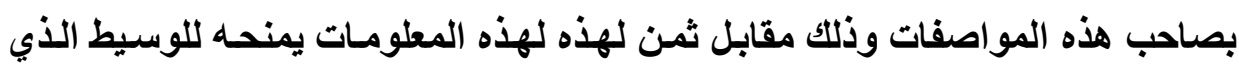

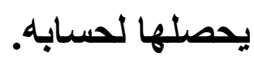

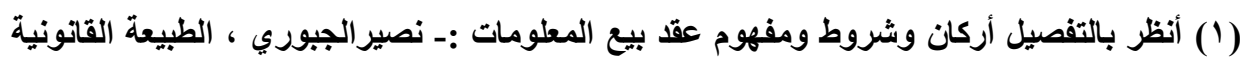

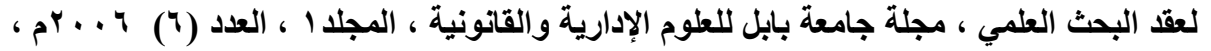

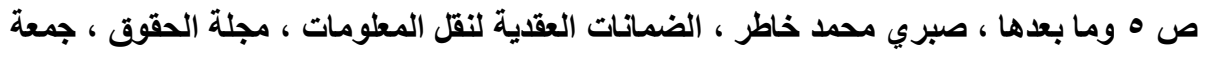

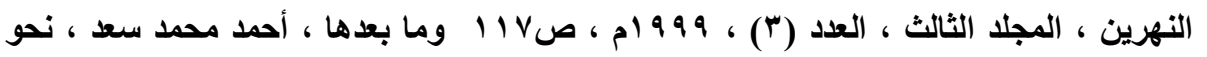

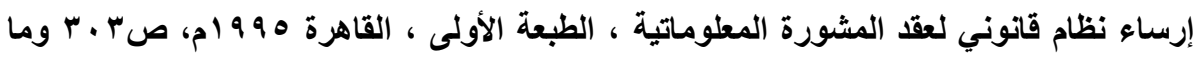


وفي الواقع ، فإنه لا يمكن تطبيق أحكام عقد بيع المعلومـات على عقد وسـاطة التوفيق في ظلال ثبوت اختلاف البنـاء القانوني لكل منهمـا ، إذ يرتكز عقد الوند الوسـاطة

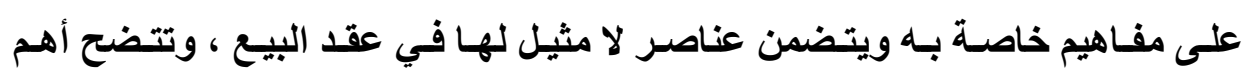
الاختلافات بينهما في النقاط التالية :-

1- إن عقد البيع ينقل ملكية المحل للمشترى بحيث يتمتع الأخير بكامل سلطات المالك

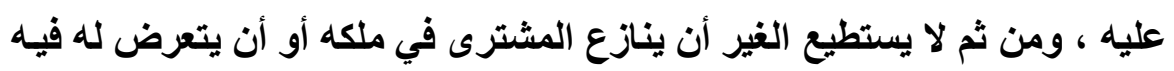

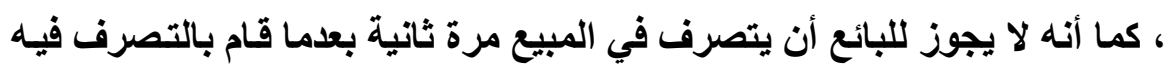

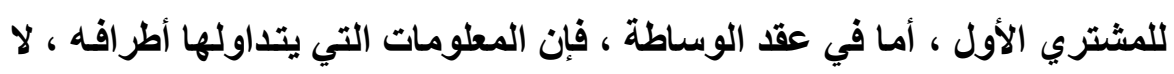

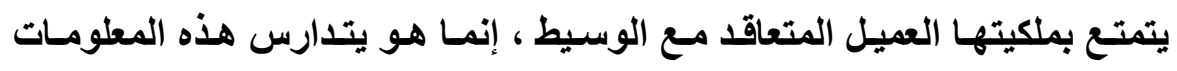
الخاصـة بشريك حياتـه المتوقع ليتخذ بصددها قرار المضي في جلسات الحوار

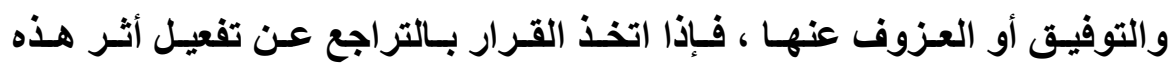

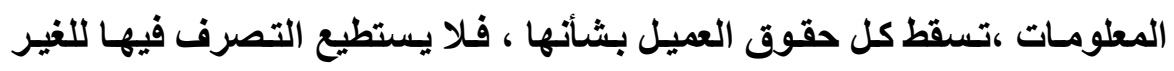

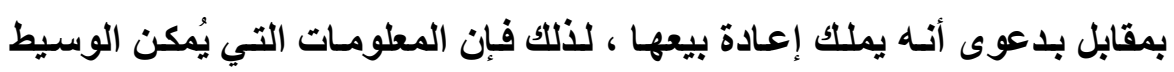

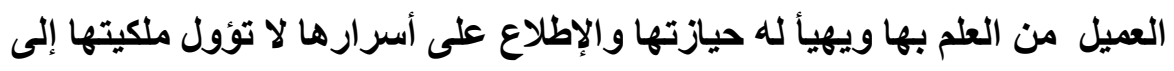
العميل الذي لا يخوله عقد الوسـاطة التصرف فيها بـل هو مؤتمن على سريتها وملتزم بعدم الإفصاح بها للغير .

r - فضلاً عن أن هناك استحالة لنقل ملكية المحل في عقد الوسـاطة إذا مـا تم اعتباره

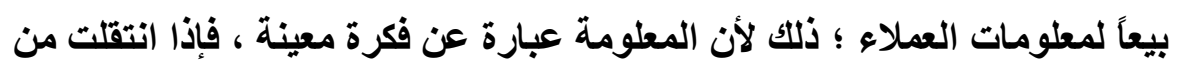
الوسبط إلى العميل صارت الفكرة بذاتها مملوكة لكليهما لأنها ستبقى لاى الوسبط (1) كفرة رغم انتقالها للعميل العيل

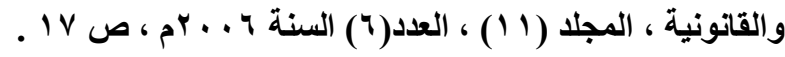


r- لا يملك العميل طلب التنفيذ الجبري عند امتــاع الوسبط عن تسليمه معلومـات شريك حياته المتوقع ، وذلك لوجود ارتباط وثيق بين المعلومة كأمر معنوي وبين الوسيط صاحب العلم بها ، وهذه الإشكالية لا نظير لها فيما تقرره القواعد الخاصة

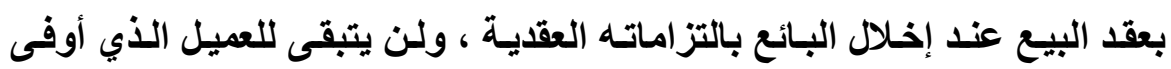
بالتزامه بسداد المقابل المادي للمعلومة إلا المطالبة بإنهاء الرابطة العقدية إذا مـا امتنع الوسيط عن تسليم المعلومة إليه لعدم موائمة التنفيذ الجبرى لاقتضائها. الإطلب الخاهمس

عقد الوساطة فى الزواج والوعد بالعقد والتعهد عن الغير

\section{الفرع الأول}

\section{الوساطة فى الزواج والوعد بالعقد}

إذا كان من الطبيعي أن يتم إبرام التصرف القـانوني مباشرة ، لكن وفي بعض الأحيان يتفق طرفيه لا على التصرف ذاته ، وإنمـا يصدر أحدهما وعداً للآخر بـإبرام التصرف الموعود به ، إذا رغب الموعود له في ذلك خلال مدة معينـة ، فيتقيد الواعد بهذا الاتفاق دون أن يلتزم بمقتضاه الموعود بشئ ، وهذا مـا يسمى بالوعد بالتعاقد ،

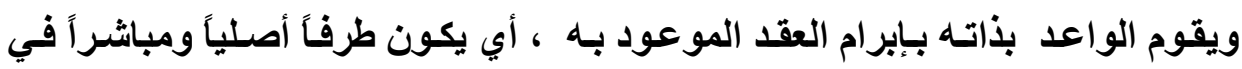

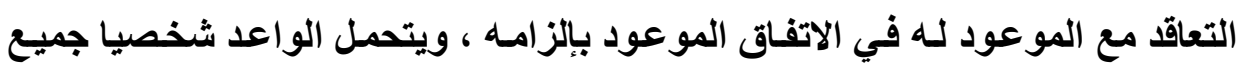
الالتزامات الناجمة عن العقد محل وعده ، ويكون حكم القاضسي حال امتناعه عن تتفيذ هذا العقد للراجح فقهاً كاشفاً وليس منشاً تأسيسياً على قيـام العقد الموعود بـه بمـا يرتبه من آثار بمجرد إعلان الموعود له الرغبة في إبرامه خلال مدة الوعد (') . 
وقد يبدو التشابه بين النظامين ، الوعد بالعقد والتوسط لأبرام عقد زواج ، من

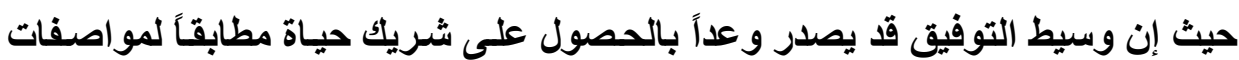
الموعود لله ثم يستطيل الوعد في مرحلة متقدمة أو متأخرة فيعد الوسيط راغب لئبرئ الزواج

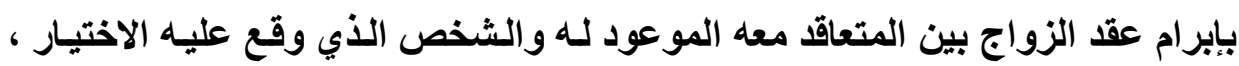

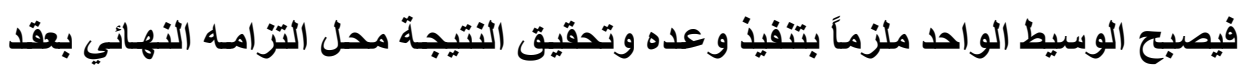
نكاح الطرفين وإلا يصبح مخلاً تنفيذ الوعد المتفق عليه . بيد أنه يتلاشى ما قد يثور من الخلط بين الوعد بالعقد وعقد وسـاطة النكاح ،

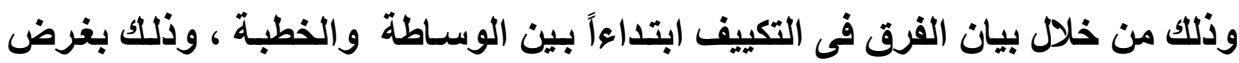

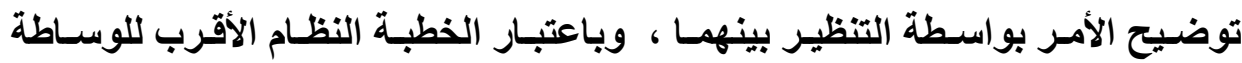

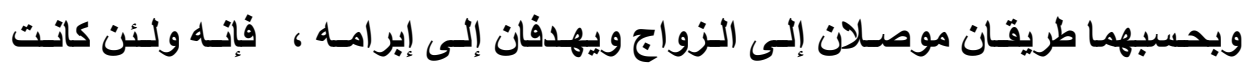

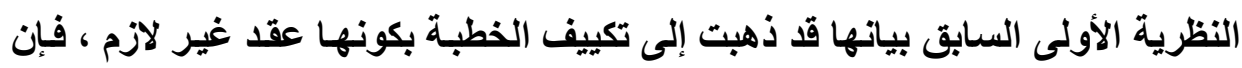

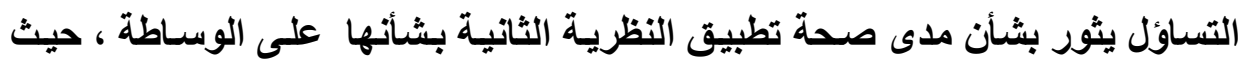

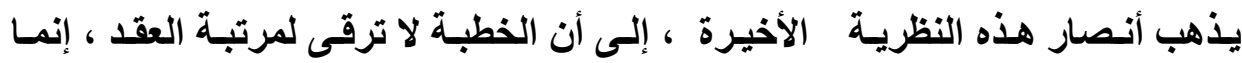
ينحصر مفهومها عند الوعد لإبرام الزواج مستقبلاً ، ويقتصر محل الوعد فيها على الونى

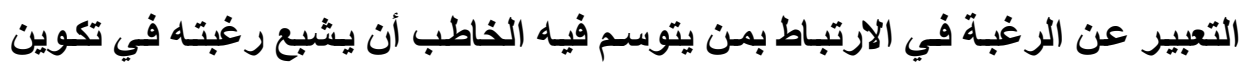

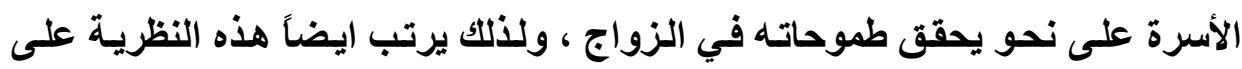

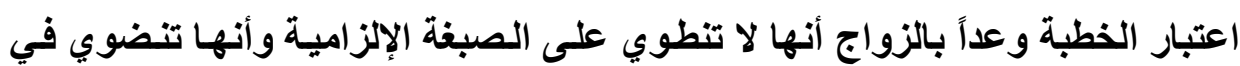

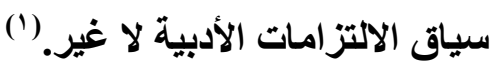

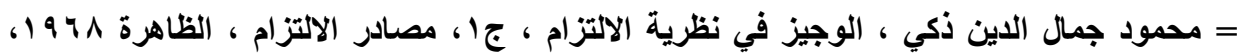

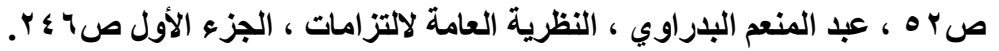

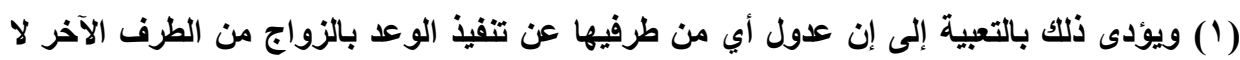

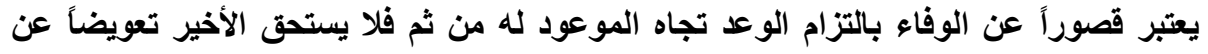

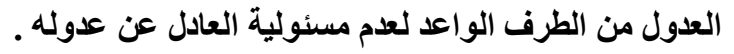


وبصرف النظر عن تفضيل أحد الرأيين السائدين في مجال تكييف الخطبة ، وبغرض نفى مفهوم الوعد بالعقد عن وسـاطة الزواج ، فبإن الحقيقة المؤكد لدينا هى ترسيخ الصبغة العقدية في عقد الوسـاطة ، إذ لامحل لإنزال المفهوم القانوني القائلـ باعتبار الخطبة وعداً على تكييف علاقة الوسيط بالعميل ، وذلك لأن عقد الزواج لا يتولا بذاته من رحم العلاقة بين الوسيط وعميله ، ولا تؤدي الوساطة مباشرة إلى إبرام عقد الزواج وإن كاتت تهيأ لإبرامه كالخطبة إلا أنها مرحلة وسطية بين توفيق التعارف من ناحية والخطبة والزواج من ناحية أخرى ، وغاية ما تهدف إليه الوسـاطة هو خلق حالـة مـن الانسجام والتوافق والقبـول لا تكسب حقوق الطرفين قوة إلزاميـة لإجبـار الطرف الآخر على الالتزام بالخطبة أو الالتزام بالزواج .

فضلاً عن أن الخطبة سواء أعتبرت عقد أم وعد فالواعد فيها أو المتعاقد يمثل طرفـاً أصلياً في علاقتي الخطبـة والزواج ، خلافـاً للوسـاطة التي يتمثل أطرافهـا في الوسيط والعميل ، ولا يستطيع الأول أن يصدر وعداً بالزواج للثانى لأنه لا يتمتع بصفة الخاطب ، كمـا لا يتسنى تكييف الوسـاطة باعتبارهـا وعداً بـالزواج مـن شريك الحيـاة المتوقع لعميل المتعاقد مع الوسيط ، وذلك لانتفاء ثمة رابطة قانونية بين طرفى علاقة الزواج المتوقعة فى الفترة الزمينة التي تجري فيها عملية التوفيق ، وعليهه لا يمكن اعتبار الوساطة وعداً بالزواج استناداً للحقيقة السابقة التي تمليها القواعد القانونية

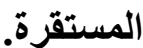
وبـذلك يتجلى الفــارق الجـوهري بـين النظـامين ، الوعـد والوســاطة ، إذ عقد التوسط بغرض إبرام عقد النكاح لا يمكن اعتباره وعداً بالزواج أو وعداً بإبرامه ، إذ أن 
دور الوسيط الذي تحدده التزاماته التعاقدية ينصرف بطبيعته إلى البحث عن شريك حياة يحمل صفات متفق عليها ثم يتحول دور الوسيط إلى المفـاوض للتوفيق بين الطرفين ، ومن هنا يكون من غير المقبول تطبيق أحكام الوعد بالعقد لكونها لا تنسجم مـع فقدان الوسـيط للصفة القانونيـة للواعد فيمـا يبرمسه بـصفته الثخصية في خصوص العقد الموعود بـه ، فالوسبيط لا يتصور فيـه أن يلعب دور الطرف المباشـر فـى الوعـد ،

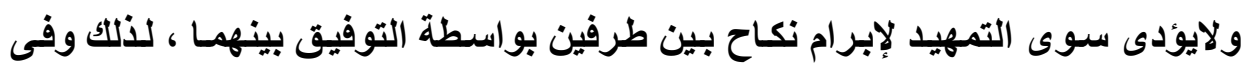

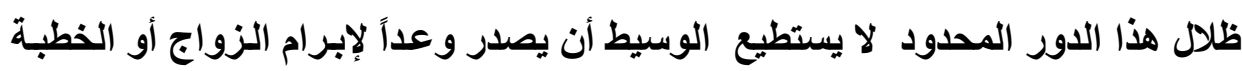
لفقدانه الصفة القانونية لأي من طرفي هذه العقود الشرعية ، أما في حالة مـا إذا صدر

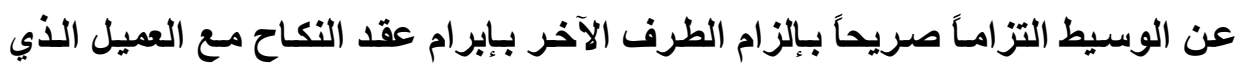
فوضه في البحث والتفاوض ، فإن الأمر يتحول من نطاق الوعد بالعقد الذي استحال تطبيق أحكامه إلى مجال التعهد عن الغير، وهذا ما سوف نتناوله في الفرع الثانى.

\section{الفرع الثانىى}

\section{الوساطة فى الزواج والتعهد عن الغير}

ويعرف التعهد بأنه عقد أو بند في عقد ملزم لجانب واحد يتعهد بمقتضاه أحد

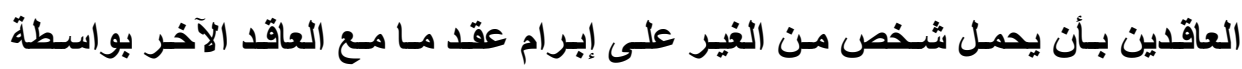
العصول على موافقة هذا الغير ، فإن ارتضى الغير بـالالتزام بإبرام العقد ، برئست ذمـة

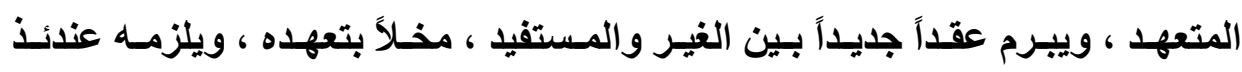

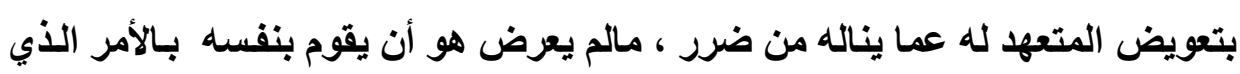

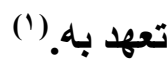

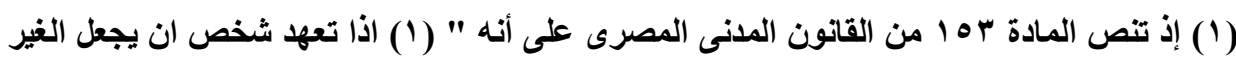

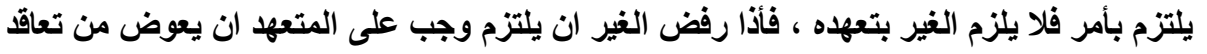

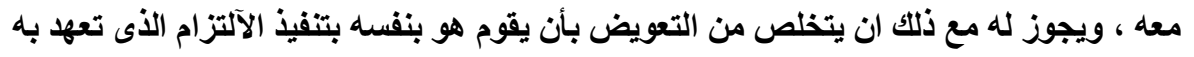

Q مجلة البحوث القانونيت والإقتصاديت 
وفى الحقيقة فإن الوساطة لا يمكن اعتبارها تعهداً من الوسيط بإلزام طرف آخر

بأن يبرم عقد الزواج مع العميل ، وذلك لأن مجرد تعه العميل بذلك يخالف النظام العام الذى يقضى كما سبق وأن بينا بحرية الزواج ، وعليه يستحيل على الوسبط أن يوفى

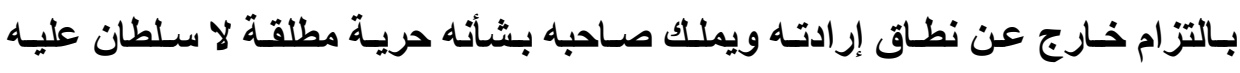
بشأنها ، ومن ثم يؤدى ذلك إلى بطلان هذا التعهد لاستحالة تنفيذ محل التزام الوسيط منذ مبدأ إبرام عقد الوسـاطة ولعدم مشروعية إجبار شخص على الزواج لأنهه العقد الأسمى فى النطاق الاجتماعى وبالتالى لا يمكن إسباغ ما ينطبق على العقود المالية من أحكام التعهد بإبرامها مع الغير وإنزالها موضع التطبيق فى نطاق عقد الزواج. فضلاً عن أن طبيعة التزام المتعهد فى الوفـاء بجعل الغير ينفذ التزامـه تجـاه المتعهد له التزاماً بتحقيق نتيجة محددة مسبقاً وهذه النتيجة كما ذكرنسا يستحيل ضمان تحصيلها فى عقد الوساطة ، بينما طبيعة التزامات الوسيط ، كالسمسار مثثلاً ، تنضوى فى سياق بذل العناية الممكنة لتحصيلها ، وأخيراً فإن تعهد الوسيط بإبرام الزواج بين العميل والطرف الآخر يؤدى لإجهاض فكرة الوسـاطة ذاتها ويجعل إبرام العقد بشأنها عديم الفائدة ، وذلك لأن هذا التعهد يتخطى مرحلة التوفيق برمتها ويضمن بـه الوسبط للعميل فرصـة الزواج المباثـر دون المـرور بمراحل البحث عن شـريك الحيـاة ودون إعمال مهارة التوفيق بينها وبين العميل ، فجميع هذه المراحل سوف تنعدم التزامسات

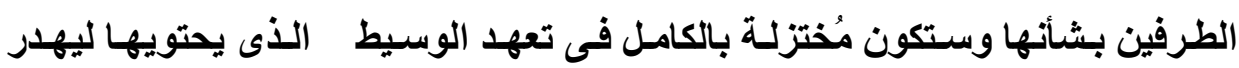


قيمتها التعاقديـة بـل وينقضى فيها عقد الوسـاطة ويتحول لعقد آخر ذو طبيعة مغايرة (')

\section{المطاب السادس}

\section{عقد الوساطة فى الزواج عقد غير مسسمى ذو طبيعة خاصة}

إن مجرد تسمية الفقه القانونى لعقد ما لا تجعل من هذا العقد عقد مُسمى، فهو

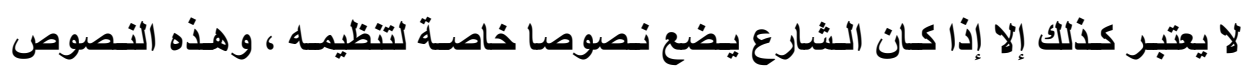
ستتضمن بطبيعة الحال إطلاق اسم معين عليه. و فى الحقيقية فإنـه لا يكاد يوجد فرق بين العقد المسمى والعقد غير المسمى في الأنظمة القانونية ، وإن كانت العقود المسماة تحكمها منذ البداية النصوص الخاصة بها ، ولا تطبق عليها القواعد العامـة إلا إذا لـ يكن هناك حكم خاص يتعلق بها في هذه النصوص ، في حين أن العقود غير المسماة محكومة أساساً بالقواعد العامـة للعقود التي تتسع لتطبيق أحكامها على جميع أنواع

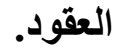

لذلك لا يلزم أن يكون العقد مسمى حتى يكون صحيحاً فى نظر القانون ونافذاً بين أطر افه ، بل يجوز العقد ويصح ولهو كان غير مسمى فى القانون ، أي ولو كسان التشريع لايتولى تنظيمة بين العقود التي يتناولها تحت اسم ووصف مُعين ، فكل اتفاق جائز وصحيح سواء أكـان القـانون قد نظمـه أم لـم يتناوله بـالتنظيم التفصيلي الدقيق ،

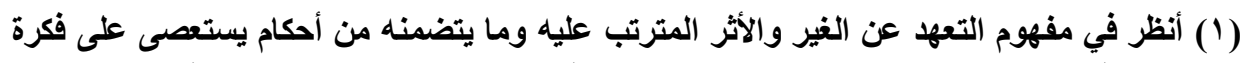

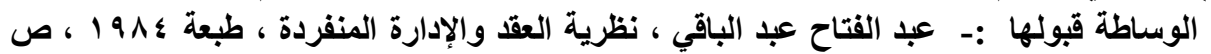

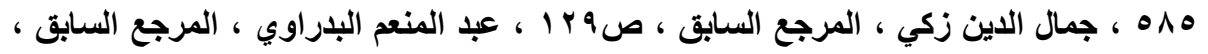


مادام أن هذا الاتفاق لا يخالف النظام العام أو الآداب ، وذلك وفقا لمبـأ سلطان الإرادة وحريتها فى إبرام ما تثاءه من عقود مسماة كاتت أم غير مسماة (1). ويتبين من مقارنة الأنظمـة العقديـة الشبيهة بعقد الوسـاطة فى النكاح أن نقاط التوافق بينهم عسيرة المنـال ، حيث يصعب إنزال الكيوف القانونية المتنوعة لبعض العقود القزيبة من مفهوم الوساطة ، وهذا ما يدفعنا إلى الانتهاء إلى أن عقد الوسـاطة بين راغبى النكاح من العقود غير المسماة فى القانون ، وإذ كانت الإثكالية تكمن فى إنى أن الأهمية العملية لتكييف الوساطة تبرز في تعيين القواعد واجبة التطبيق عليه ، حسال عرضه على القضاء أو النزاع بشأنه كعقد مـا في خصومة معروضـة عليه ، لذا فإنهـ يتعين على القضاء أن يجته فى ظلال هذا الفراغ التشريعى بـأن يجري أحكامسه على أسـاس تحري المقاصد العملية لأطراف عقد وسـاطة النكاح ، ومطابقة هذه المقاصد على النظام القانوني للعقود المعروفة ، ليحدد الآثار الأساسية التي اتجه طرفـاه إلى تحقيقها، وأن يستظهر الغايسات العملية التي اتجهه طرفا العقد إلى بلوغها ، وبصرف النظر عن أية تسمية يطلقها المتعاقدان على هذه المقاصد أو على العقد في جملته.

(1) أنظر فى مفهوم وأنواع العقود المسماة وغير المسماة : عبدالفتاح عبدالباقى ، نظرية العقد

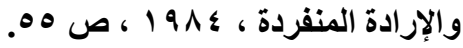

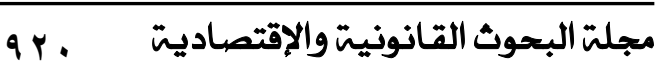




\section{الفصل الثاني \\ آثار عقد الوساطة للتوفيق بين راغبى الزواج}

إذا كاتت العلاقة القائمة بين وسيط التوفيق وراغبى النكاح تُعد صورة من صور

التعبير عن الإرادة التعاقدية بحيث تصلح لبنـاء أتفـق تعاقدي متكامل الأركان ، وأنها تتعدى مفهوم الأعمال المادية أو الوقائع القانونية التي لا يتمخض عنها تكوينـاً عقدياً، لذا فإن إخضاع العلاقة بين وسيط الزواج و عملائهـ للمفهوم التعاقدى المحض ، يؤدى إلى ضرورة الانتقال إلى بيان الآثار التى تتولا عن هذه العلاقة العقدية من خلال شرح مضمون الالتزامات التى يرتبها عقد الوسـاطة فى ذمـة طرفيها مـع تنـاول طبيعة هذه الالتزامات مع الإثـارة على انعكاسات ذللك على مسؤولية الوسيط المدنية كلمـا يقتضى المقام ، الأمر الذى نرى معه تقسيم هذا الفصل إلى مبحثين أساسين وعلى النحو

المبحث الأول :- الالتزامات التي يرتبها عقد الوساطة فى ذمة الوسيط.

المبحث الثاني :- الالتزامات التي يرتبها عقد الوساطة فى ذمة العميل. 


\section{المبحث الأول}

\section{الالتراهات التي يرتبها عقد الوساطة فى ذهة الوسيط}

يُنشأ عقد الوساطة بين الراغبين في الزواج اتفاقًاً بين الوسبطوعمليه على خلق التزامات متبادلة كنتيجة مباشرة للتعبير الصريح عن الإرادة الصادر منهمـا ، ، ، فطلب الوسبط الصادر عن العميل شفوياً كان أم كتابياً يُعد تعبيراً إرادياً صـادراً عنه برغبته الجازمة في البحث عن شريك حيـاة وتحقيق الارتباط بـه ، ويمثل هذا الطلب ركن الإيجاب التعاقدي الصادر عن العميل ، ويُعتبر قبول الوسيط للقيام بالمهمة محل هذا الإيجاب مقابل أجر محدد من الأمسور المُتمــة لإبرام عقد الوسـاطة بمختلف أركانـه فيما بينهما ـ وبمجرد انعقاد الوساطة بقبول الوسيط لإيجاب العميل ، تتولا التزمات فى ذمة الأول لصالح الأخير .

ومن خلال تتبع طبيعة وسياق المهمة التى يقوم بها الوسيط من الناحية العملية، وفى ظلال الفراغ التشريعى لتنظيم هذه المهنة ذات الابعاد الاجتماعية الهامة ، وبـالنظر إلى ما يتحمله أرباب المهن الحرة عموماً من التزامات ينظمها القانون بمقتضى العقود المسماة الخاصة بهم ، فإنه يمكنتا حصر الالتزامات العقدية التى يتحمل الوسبط عبء الوفاء بها بصورة رئيسية ، فى مجموعة من الواجبات التى نرى تناولها من خلال

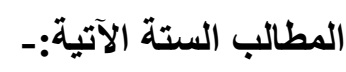

المطلب الأول :- الالتزام بالبحث وإيجاد شريك الحياة وفق اشتراطات العميل. المطلب الثانى:- الالتزام بالاستعلام والتوثق من صحة المعلومات المتداولة. 


$$
\begin{aligned}
& \text { المطلب الثالث :- الالتزام بالتوفيق بين راغبى الزواج. } \\
& \text { المطلب الرابع:- الالتزام بالسرية والإفصاح. } \\
& \text { المطلب الخامس:- الالتزام بالإعلام والتبصير. }
\end{aligned}
$$

المطلب السادس:- الالتزام بعدم مخالفة أحكام الثريعة الإسلامية.

$$
\text { المطاب الأول }
$$

\section{الالتزام بالبحث وإيجاد شريك الحياة وفق اشتراطات العميل}

$$
\text { ينقسم هذا المطلب للفرعين الآتيين :- }
$$

الفرع الأول :- طبيعة ومضمون التزام الوسيط بالبحث عن شريك الحياة المطلوب.

الفرع الثانى :- طبيعة ومضمون التزام الوسيط بإيجاد شريك الحياة المطلوب.

\section{الفرع الأول}

\section{طبيعة وهضمون التزام الوسيط بالبحث عن شريك الحياة المطلوب}

ينعقد الاتفاق المبرم بين العميل والوسيط ، بالتقاء الإيجـاب الصادر عن العميل بطلب الحصول على شـريك حيـاة بمواصفات معينـة ، مـع قبول الوسيط القيـام بتلك المهمة لقاء أجر مُتقق عليه ، لذلك يلتزم وسيط الزواج ابتداعاً وبمقتضى هذا العقد ؛ بتشخير كل إمكاناته المادية والبشرية فى شـأن أعمـال البحث عن الطرف الآخر رجلاً كان أم امرأة ، فعملية البحث تمثل منطقياً البداية الأولية لأعمال الوسيط التى يوفى بها التزاماته التعاقدية بحسب الترتيب الزمنى لها ، وينصرف محل هذا الالتزام إلى أن يبذل الوسيط مساعيه الممكنة لإيجاد شخص آخر يكون راغبـاً فى الارتبـاط كذلك ، ويستوى 
أن يكون هذا الطرف الثانى متعاقداً مـع ذات الوسيط للبحث عن شريك حيـاة أم يكون

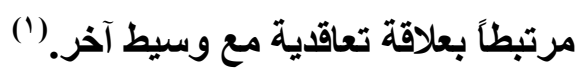

ولاشك فإن عملية البحث لا ثُعد من إطلاقات الوسيط ، بل يجب أن تنضوى فى هـ مجموعة من الضوابط والقيود القانونيـة والشرعية المُقررة ، فينبغى بـاعة أن يكون نطاق بحث الوسيط محدداً بإيجاد شخص يختلف فى الجنس البشرى عن جنس العميل ، فهذا الاختلاف يمثل شرطاً مفترضاً فى عملية البحث ، لذلك يُمتنع عن الوسيط أن يوفق بين المتمـاتلين فى الجنس الواحد رجـالاً كـانوا أم نسـاءً ، كمـا يحد مـن نطـاق البحث ضابطاً آخر ، إذ لا يجوز للوسيط أن يستجلب شخصاً للعميل لا يسمح القانون أو الشرع بانعقاد الزواج بينهما لمخالفة ذلك العقد للنظام العام والآداب العامة ، فلا يجوز التوفيق لذلك بين الأقارب من المحارم ، أو بين من يحملون ديانتين مختلفتين ويمنع الشرع الزواج بينهما ، أو بين من ينتمون لعقائد شاذة غير سماوية ، أو للتوفيق ببين طرفين تحت السن القانونى للزواج ـ وكقاعدة عامة يُمتنع على الوسبط كمبدأ الوفـاء بـالالتزام بالبحث بغرض التوفيق لإبرام علاقة زواج محظورة بالشرع والقانون ، ويترتب على ممارسة الوسيط لهذا النوع المحظور من البحث قيام الحق لدى الطرف الآخر فى فسخ عقد الوساطة لإخلال الوسيط المتمثل فى وفائه بالالتزام بالبحث فى نطاق غير مشروع

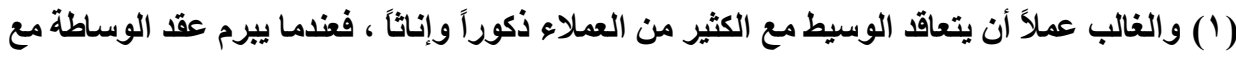

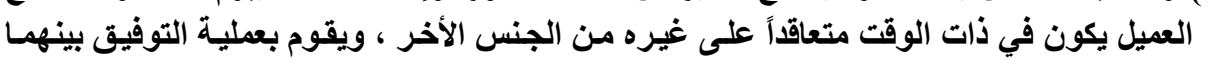

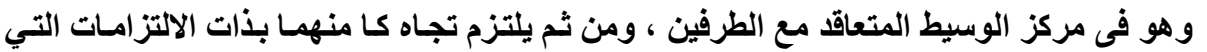
يفرضها عقد الوساطة لاتحاد طبيعة العقد المبرم معهما . 
لا يتقق مع القواعد الأساسية للنكاح الثرعى وهى قواعد بطبيعتها متعلقة بالنظام العام

(') الآمر.

وتتحدد طبيعة التزام الوسيط فى هذه المرحلة فى نطاق بذل العنايـة المُمكنة دون

إلزامه بنتيجة محددة مسبقاً ، فهو كمهني متبصر ، ملزم ببذل عناية الرجل المعتاد في

إنجـاز مهمـة البحث الموكولـة إليـه مـن العميل ، وهـي هنـا عنايـة مـن النـوع المهني المُتبصر المُحترف من طائفة وسطاء التوفيق في مجـال الوسـاطة المطلوبـة ، فعليه أن يكون مُلماً بصيراً بالعادات السائدة والواجبات المفروضة في نطاق مهنته وأن يتوافق سلوكه معها (r) (ن)

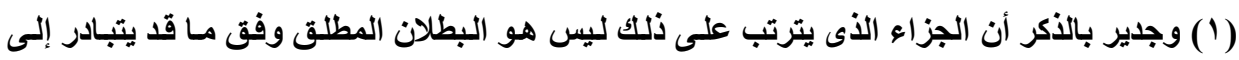

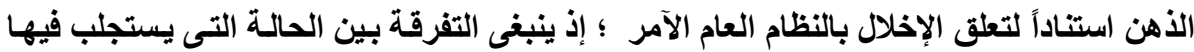

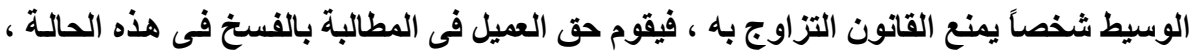

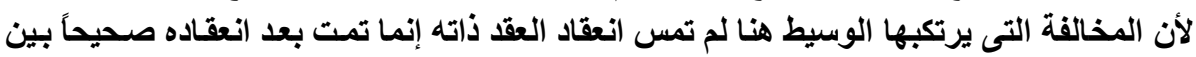

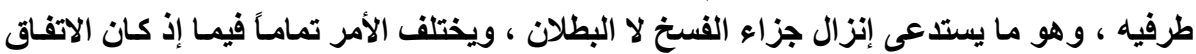

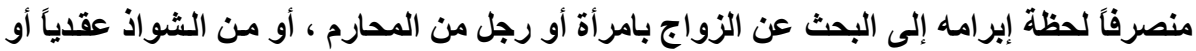

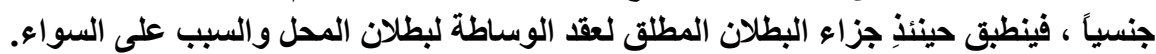

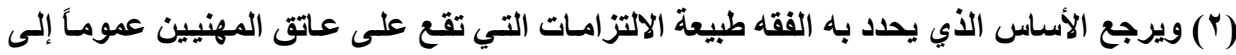

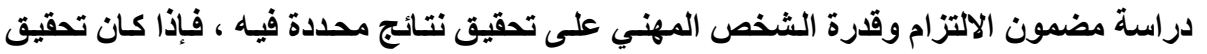

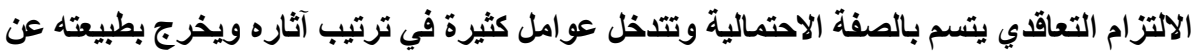

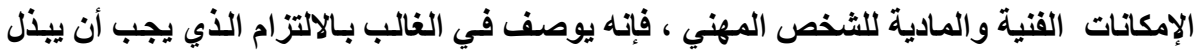

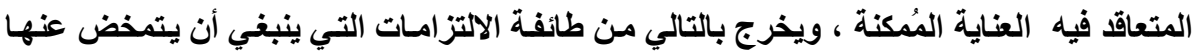
نتائج محدده .

أنظر في بعض تطبيقات ذلك :- عبد العزيز سليم ، قضايا بالتعويضات ، الطبعة الثالثة ، المحلة ، الثية

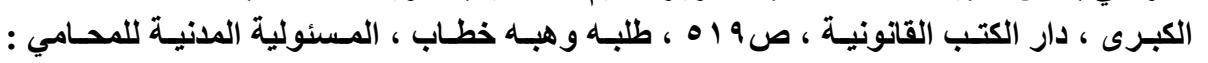

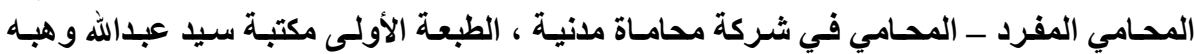

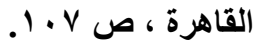


لذلك ينبغي القول ، أن طبيعة التزام وسيط الزواج بالبحث عن الطرف الأخر لا يتعدى مفهوم الالتزام بيذل عناية الرجل المعتاد في نطاق عملية البحث وملابساتها ، فالوسيط ينتمي إلى وسط مهني ، هو دائرة الحرفة التي يمسارس فيها نشاطه ، ويقاس التزامه بأداء مهام البحث عن شريك الحياة المرغوب ، بمعيار سلوك المهني المعتاد من أفراد مهنتهـه ، وفي مثنل ظروفه التي يعمل فيهـا ، فيلتزم الوسيط بالقيـام بالعمل المعهود إليهه ، ومقتضاه أن يحضر العملية طرف آخر مهيئاً لإمكان الدخول معه في علاقة زواج شرعية ، في حدو الشروط والمواصفات التي يطلبها العميل . ويقاس التزام الوسبط بالعنايـة الواجبة التي تعتبر معيـارً لاستخلاص الإخلال الذي يقع منـه بـالجهود والقواعد المهنية ، بواسطة مراعـاة كافة الظروف الخارجية التي يعمل الوسيط فيها ، كالعوامل الخارجية من المكان والزمسان وطبيعة المواصفات

$$
\text { والشروط التي يختصها العميل فيمن يرغب الزواج به ـ }
$$

لذلك يعتبر الوسيط مقصراً ، إذا قعد عن تنفيذ التزامسه بالبحث كلياً ، أو تراخي في إتمامه زمنياً لمدة لا تتناسب البتة مع حاجة العميل في الارتباط والزواج الشرعي ، أو إذا حصر نطاق بحثه في جهة جغرافية معينة أو في نطاق وظيفي مُحدد يستحيل أن يتحصل فيها منطقياً وواقعياً على الشريك الشرعى المطلوب ، أو عند قيامـة بالبحث لاى طوائف معينة لا يجوز الاخول معها فى علاقات شرعية لاتحاد النوع بينها وبين العميل أو لاختلاف الديانة أو لوجود مانع شرعى للزواج كالمحارم. 


\section{الفزرع الثاني \\ طبيـة وهضمون الالترام بإيباد شريك الصياة \\ بالشروط والمواصفات المتطلبة}

لا ينحصر التزام الوسيط في بذل العناية الواجبة للرجل المعتـاد في شـأن إعمال

مجهوداته المهنية فى البحث والتحري عن شريك الحياة الاحتمالي فحسب ، بل يتعين أن يمضى التزامه نحو إيجـاد شخص ذو مواصفات واشتر اطات موضوعة مسبقاً من العميل ، وتبدو بذلك التفرقة جلية ، بين مضمون ومحل التزام الوسيط بالبحث عن شريك حياة متوقع ، وبين ما يقابل ذلك في التزامسه بإيجـاد هذا الشريك على نحو ذي خصائص ومزايـا مُحددة يشترط العميل توافرهـا فيها سـلفاً ؛ ففى الالتزام الأول يكون المحل متمثلاً فى مجرد بذل المساعي المُككنة فحى عمليـة البحث عامـة ، مـع ضرورة مراعاة الضوابط الأساسية التي يجب أن تحيط عملية البحث والتى سبق إيضاحها ، وعلى عكس ذلتك يتطور مضمون المحل فى الالتزام الثـانى إلى مرحلـة إيجـاد فعلى لثريك الحياة المطلوب بمواصفات خاصة يطرحها العميل مقدماً ويشترط تحقيقها فيه بصورة أساسية .

ويـعكس اختلاف المضمون السـابق للمحل ليجعل مـن التزام الوسبط بإيجـاد شريك الحياة التزاماً ذو طبيعة مغايرة لطبيعة التزامسه بالبحث عن هذا الشريك ، فِإذا كان التزام الوسيط بالبحث والاستكشاف لا يكون محله تحقيق نتيجة محددة ، بل يبذل الوسيط إزاعه عناية الرجل المعتـاد وفقاً لمـا تقدم إيضاحه ، فعلى عكس ذلكك ، يـأتى التزام الوسيط بايجاد شريك حياة ذو طبيعة مغايرة ، فينطوى فى سياق الالتزامات التى 
يجب أن يتولا عنها نتيجة محددة (') ، تتمثل في التزام الوسيط بتقديم طرف آخر يتمتع بذات الخصائص المرغوبة من العميل المتعاقد مـع الوسيط ، وبمعنى أكثر دقة ، يجب أن تؤتى مجهودات عملية البحث أثراً ملزمـاً للوسيط ، وهو وجوب التزامسه بتحصيل المواصـفات الإنسـانية والماديـة التـي أعلن العميـل عن وجـوب توافرهـا مقـدماً ، ولا يستطيع الوسيط أن يتخلص مسن مسؤولية الوفـاء بهذا الالتزام ، بإثبـات أنـه قد بـل العناية والمساعي الممكنة فى سبيل تحصيل الشخص المرغوب ، بل يتعين أن يحقق للعميل النتيجة المحددة سلفاً ، وهى أن يستجلب له شخصاً يحوز ما افترضه فيه العميل من خصائص لا فكائ من تحصيلها فيه. ويرجع تبرير ما نذهب إليه فى شأن استخلاص طبيعة خاصة فى التزام الوسيط بايجـاد طرف آخر ذو صفات خاصـة ، إلى أن اشتراطات العميل فـى شـريكه المتوقع للحيـاة الزوجيـة غالبـاً مـا تكون هـ السبب الدافع لإبرام عقد الوسـاطة ، حيث يكون

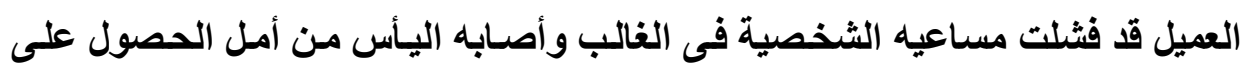
مواصفات معينة فى زوج المستقبل ، ومن ثم يدفعه ذلك إلى إبرام عقد الوساطة بغرض تفويض وسيط الزواج بوصفه مهنياً محترفاً فى البحث لإيجـاد المواصفات التى عجز عن تحصيلها ؛ والتى قد يعزف عن الاخول في علاقة الزواج من الأصل إلا إذا توافرت هذه الاشتراطات كنتيجة مطلوبة سلفاً فى شريك حياته المرغوب ، لذلك يطرحها العميل

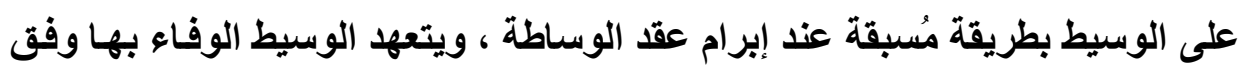

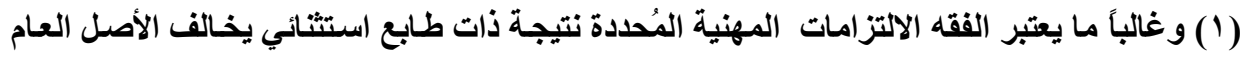

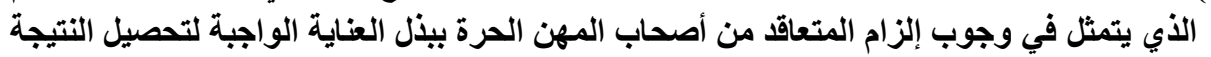

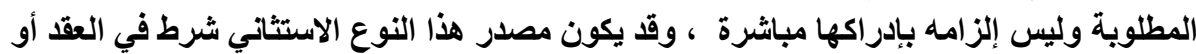
في القانون أو يُستنبط من طبيعة الخدمة المقدمة أو الحماية الواجبة للمتعاقدين مع المهنيين ـ 
الـصورة المُحسدة التـى طرحت عليـهـ دون أن يستطيع المسساس بهـذه الخـصائص المشترطة كماً أو كيفاً إلا بموافقة العميل أولاً.

ورغم ما نعتقد بضرورة إعمالهه من التفرقة المشار إليها بين طبيعة الالتزام بالبحث عن شريك الحياة وطبيعة الالتزام بتحصيل الصفات والشروط المُحددة فيه ، إلا أنه ينبفي علينا أن نؤطر حدود تلك الصفات والاشتراطات التي يتسنى للعميل طرحها على الوسيط ، وتتلك التي يتمكن الأخير في ذات الوقت من تنفيذها بوصفها نتيجة مُتفق علي تحديدها سلفاً ، ونرى أن الإطار المقبول في هذا الصدد ، هو ضرورة عدم تجـاوز هذه الشروط والمواصفات الحدود المعقولـة إلى المبالغـة والإفراط ؛ فيجب لـذلك أن يكتسي إطار المواصفات المرغوبة في الزوج المتوقع بالانضباط والمعقولية اللازمين ، وأن يخلع العميل من نطاق اشتراطاته جميع الرغبـات المُستحيلة أو المُتتاقضة ، وأن توضع معقوليـة الشروط التي يتطلبها العميل في ميزان الخصائص والمُميزات التي يتمتع بها هو شخصياً ؛ إذ يكون من غير الملائم إلزام الوسيط بتحصيل شريك الحياة بصفات مادية وخلقية لا تتناسب البته مع ما يتمتع به العميل ذاتـه من مزيـات وصفات متواضعة في السياق الاجتماعي عامة ، لذلك يجب أن تكون متطلبات العميل فى مسألة الصفات مقبولة ومعقولة وغير متناقضة أو شاذة .

فإذا كان العميل بذاته ليس من أصحاب المزايـا الوظيفيـة أو المهنية المرغوبـة أو الرائجة ، و إذا كـان لا يتمتـع بخصائص جسمانية مُميزة أو لا يحـوز مـلاعة ماديـة كبيرة ، فإنه فلا يستساغ منه فى ظلال هذه الصفات ذات الثأن المتواضع ، أن يشترط على الوسيط تحصيل شريكاً لحياته من ذوى الوظائف أو المهن الرفيعة ، أو أن يتطلب

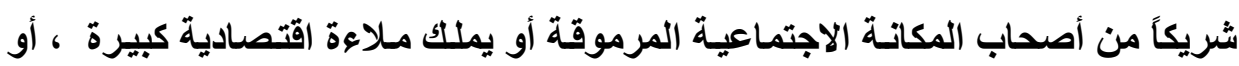
مواصفات جسمانية فائقة ، فالتعادل المطلوب قيامه بين الزوجين بصفة عامـة ، ينبغى لابـ 
كذلك تحقيق مقتضاه عند التوسط للتوفيق بين الراغبين فى الزواج ، لأن التوفيق هو المُقدمة التى يتوقع الأطراف انتهائها بـالزواج بحسبها تلعب دور التوطئة لـه ، ولأن هذا العقد الشرعي الأخير يقوم فـى جوهرة على الملائمـة والتفـاهم والقتاعة ، وأن الاختلال الثاسع فيه بين مواصفات الزوجين يعلب دوراً كبيراً فى إحداث الفرقة بينهما والتي غالباً مـا تنتهى بـالطلاق ، لذا لزم التنويـه بضرورة تقليص حدود الحريـة التى يتمتع بها العميل فى التسلط بمفرده على طرح الصفات التي يرغبها فى شريك حياته ، فضلاً عن وجوب إنزال أثر هذه القيود التي تحد من رغبـات العميل على طبيعة التزام

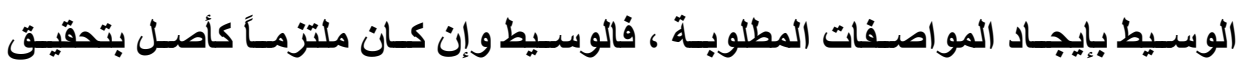
مواصفات العميل المشترطة سلفاً ، لكن خروج هذا الأخير عن حدود المعقولية بفرضهـ

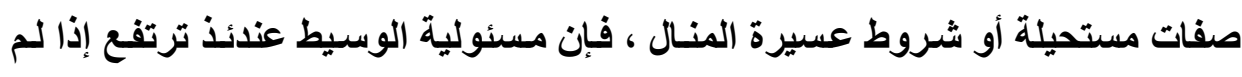

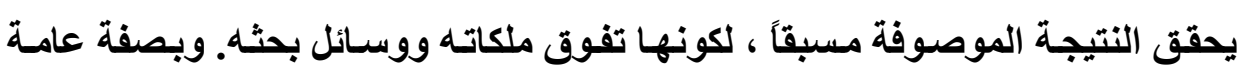
يمكنتا القول بأنه إذا كان من حق العميل وضع الصفات التي يرغبها في شريك حياته ، وأن على الوسيط التزامًا بتحقيقها بعينها ووصفها المحددين ، إلا أن هذا الحق يجب أن يُمارس من خلال ضوابط معينه أهمها عدم التعسف في استعماله إزاء الوسيط وانتفاء الاستحالة عن إمكانية تحقيق مقتضياته وتوافر المعقولية الضابطة لقبول الاشتراطات

الثخصية المحددة مسبقاً . 


\section{الإطلب الثاني \\ الالتتزام بالاستعلام والتوثق هن صحة المعلوهات \\ والصفات الإتداولة}

$$
\text { وينقسم هذا المطلب إلى الفرعين التاليين :- }
$$

الفرع الأول :- مضمون الالتزام بتوثيق صحة المعلومات والصفات المتداولة. الفـرع الثـاني :- نطــاق وطبيعـة الالتـزام بتوثيـق صــة المعلومــات والـصفات

$$
\text { المتداولة. }
$$

\section{الفرع الأول}

\section{هضمون الالتزام بالاستعلام والتوثق هن صحة}

\section{المعلوهات والصفات المتداولة}

يقوم جوهر عمل الوسبط بين راغبي الزواج على أسساس تناقل مجموعة من

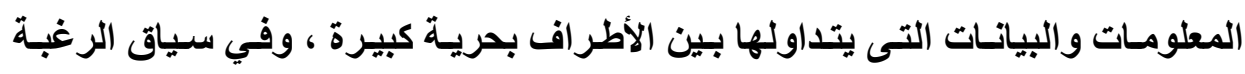
المتزايدة للدى الأفراد في التزاوج وتكوين الأسرة ، قد يسعى كل من طرفي العلاقة الراغبة في الارتباط ، إلى تحسين الصورة الجسمية له وترقية صفاته ومزايـاه المادية والأدبية حتى تحوز القبول لاى الطرف الآخر ، وذلك بغرض أن يدفعه إلى الزواج وأن

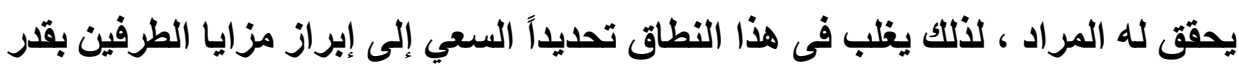
من المبالغة ، والتي قد يتطور أمرهـا إلى أن تتحول بها العيوب والنقائص الجسمية والمعنويـة إلى محاسن ومُحفزات يستجلب بها كل طرف شريكه الآخر ، بل ويجاهد 
لإقتاعه بمحاسنها والتأثير على مزاجه الشخصي بمقتضاها لتحوز رضـائه فيُقدم على

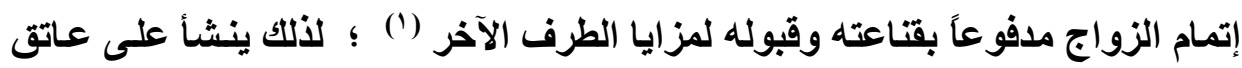
الوسيط التزاماً جوهرياً بـالتوثق من صحة المعلومـات والصفات التي يتناقلها العمـلاء

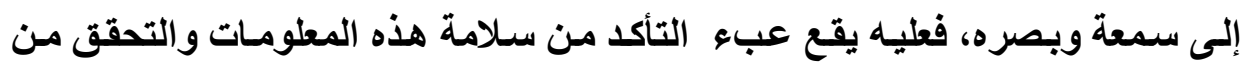
دقتها ، لأن جوهر عملية التوفيق لا يلقى على الوسيط مسئولية نقل هذه المعلومـات للطرف الآخر كما وصلت إليه فحسب ، بل يتحمل بموجبها مهارة الجهد الذي يستوثق لهان به من توافقها مع الواقع وخلوها من الغث التدليس (r).

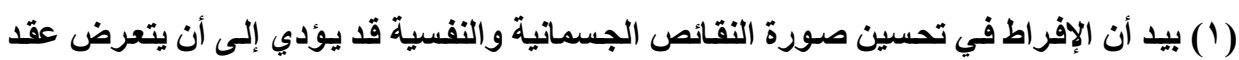

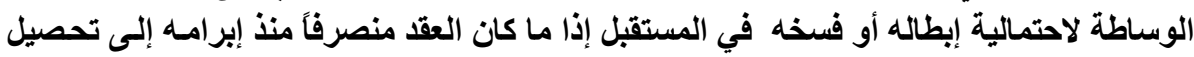

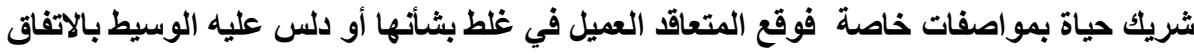

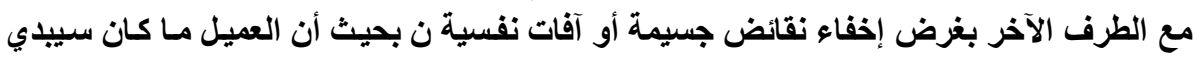

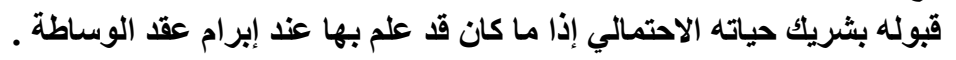

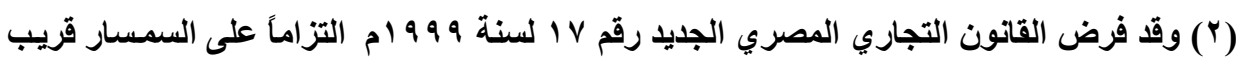

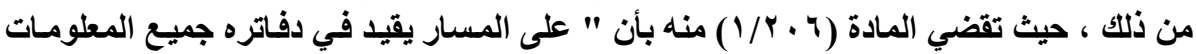

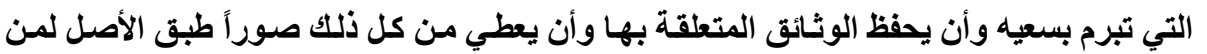

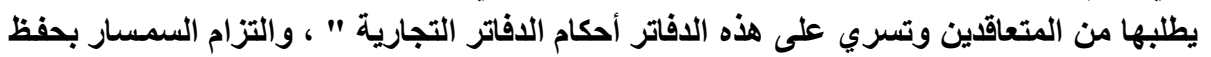

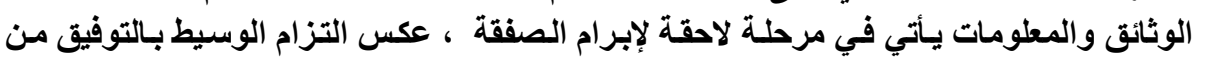

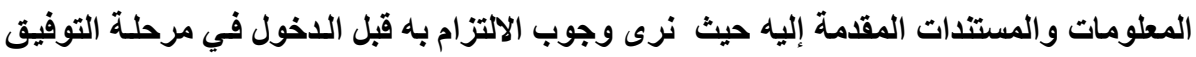

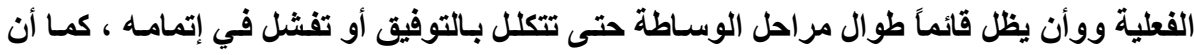

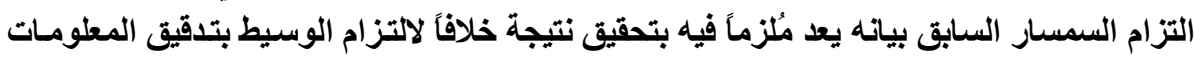

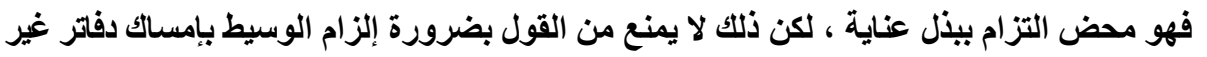

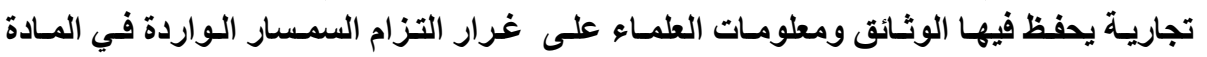
. (1/ ( $1 / 4)$

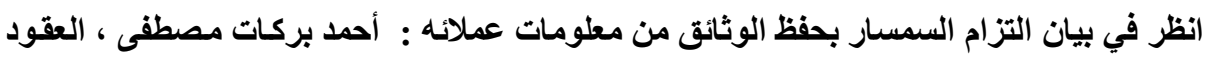

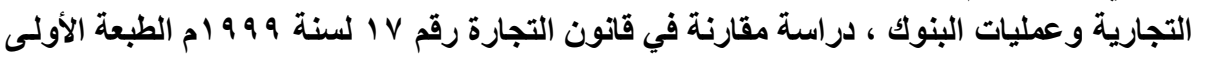

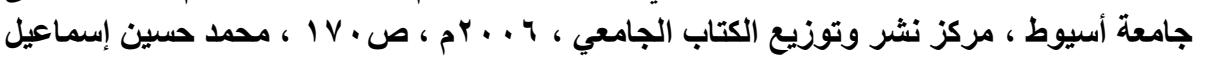

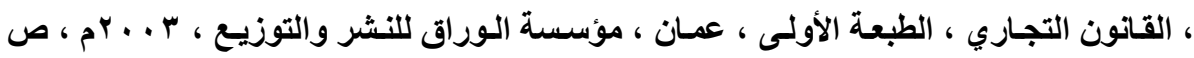


وما دفعنا بصفة أساسية إلى نرمي بهذا الالتزام على عاتق الوسيط ، مع ما فيه من مشقة كبيرة ؛ هو ما وصلت إليه تقتيات التظور الحديثة من خلق العديا من الوسيائل الاكتثرونيـة للتواصل مـع راغبي الززواج ومحاولـة التوفيق بينهم ، فـالموفق الفردي أضحى دوره مندثراً في ظلال ثورة التكنولوجيا الحديثة وتكاثر دور العمل المؤسسي في هذا المجال ذو الطابع الاجتماعي العام ، فأصبحت مكاتب التوفيق الاكترونية والواقعية منتشرة بصورة كبيرة ، وهذا ما يفتح المجال أمام خطورة تداول المعلومسات والبيانـات بصورة غير مضبوطة تكثر فيها المغالطات والمبالغات بسبب اتساع الرقعة الجغرافية التي تعمل فيها مكاتب التوفيق واعتماد الكثير من الأفراد عليها في تحقيق حلم الزواج ، وهو ما يلقى عبئًا عسيراً على الوسيط بضرورة التوثق من صحة وسلامة جميع ما يرد إليـه مـن العمـلاء مـن بيانـاتهم الشخصية وخصائصهم وصـفاتهم الأتيـة ، وأن ينقلهـا للطرف المقابل بعد تتقيتها من مظاهر المبالغة وتتقيحها من مواطن الغش والتدليس الذي يفسد ركن الرضا لدى العميل بصفات شريك حياته المتوقع .

\section{الفرع الثاني}

\section{نطاق وطبيعة الالتزام بالتوثق هن صحة المعلوهمات والصفات المتداولة}

نظراً للعقبات التي تعتري مهمة الوسيط في التتقيب عن صحة المعلومـات التي أمده العملاء بها ، أو التي يتولي هو تزويـ المتعاقد معه بمفرداتها ، ففي ضوء هذه

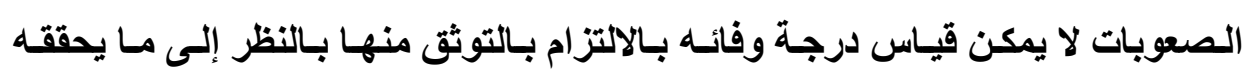
بشأنها من نتائج محددة ، إذ ذلك سـوف يلزمسه بالاستيثاق المطلق الذى يتم بـه تأكيد صحة كل معلومة طرحت عليه عند بلء التعاقد أو وقعت فى مرمى البصر والسمع أثناء

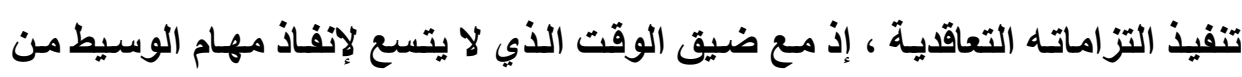


البحث عن المواصـفات المطلوبـة لكل عميل على حـده ، وفي ظـلال اتسـاع الرقعـة الجغرافيـة التـي يعمـل فيهـا ، والتزايـــ المفـرط في أعداد السكان ، وتقطع الأواصـر الاجتماعية ، أضحى إلزام الوسبط بالتحقيق والتدقيق فى كل معلومـة وصفة تصل إلى

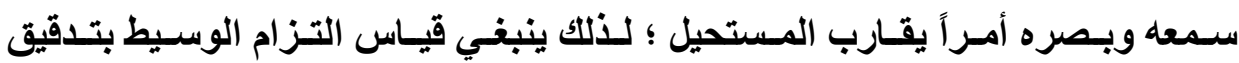
معلومات العملاء وبياناتهم بمدى العناية المعتادة التي يبذلها في سبيل الاستيثاق منها ، بحيث يتخلص وسيط النكاح من المسئولية عن أداء التزامه بـالتوثق من المعلومـات إذا أثبت أنه بذل في سياق تحصيل التزامه عناية الرجل المعتاد المتبصر ، والذي يعمل في هي ذات الظروف والملابسات ، ويتمتع بإمكانـات البحث والتدقيق المتوفرة لدى الوسبط

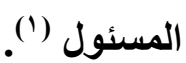

لذلك يُسأل الوسيط عن كل تقصير يصدر عنه أثنـاء ممارسـة مسلكه المهنـي السابق لا يكون متفقاً مع سلوك كل وسيط زواج ذو جهود يقظة مستنيرة وصـادقة في

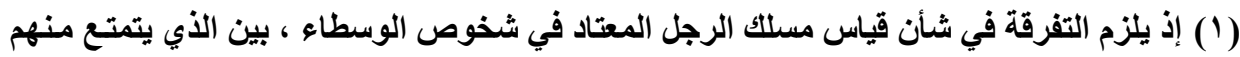

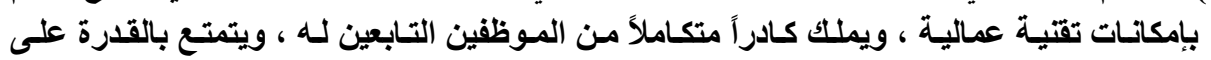

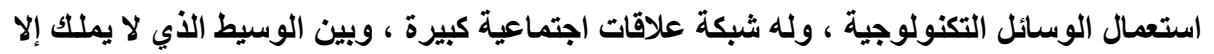

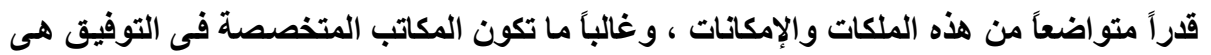

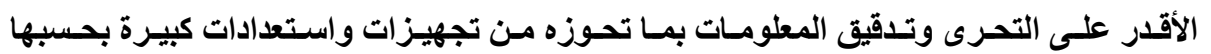

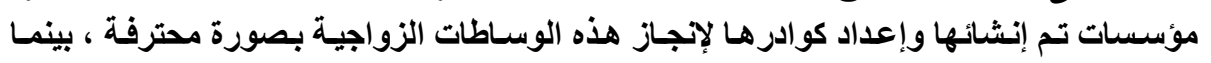

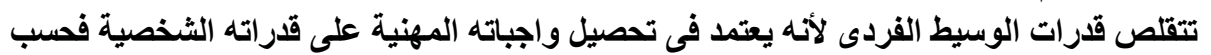

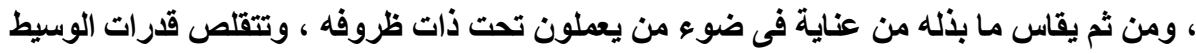

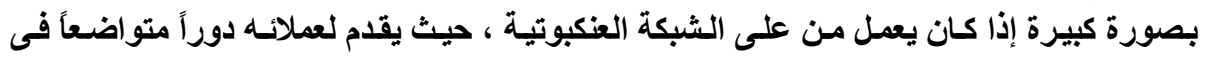

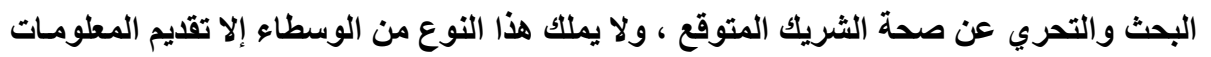

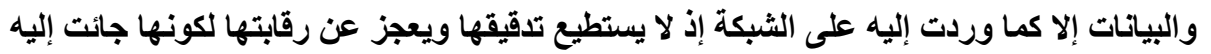

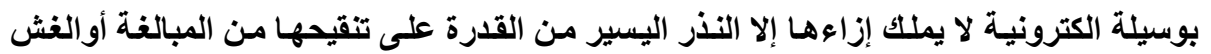

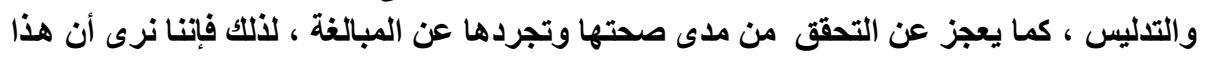

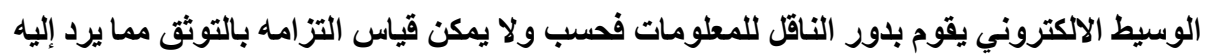
من بيانات محملة على دعامات الكترونية إلا فى ضوء طبيعة الظروف التى يعمل فيها . 
ذات مستواه المهني ، ومحيط بذات الظروف الخارجية التي أحيط بها الوسيط المتعاقد ، ومن ثم يستطيع الوسيط أن يتخلص من المسئولية إذا ما أثبت أنه قد أوفى بكل موجبات العناية المعتادة وبذل الجها المعقول والمهام المتكاملة في ظلال الظروف المعتادة التي يمكن أن يعمل في ظلالها أي وسيط يوازي مستواه وخبراته المهنية ('). وتطبيقًا لمفهوم العناية المعتادة في محل الالتزام بـالتوثق من المعلومـات ، فلا يفترض في الوسيط التقصير بمجرد تحقق الخلل في صحة المعلومـات ، للتلك لا يسأل الوسبط بمجرد أن يثبت العميل عدم صـحة المعلومـات التي أمـده بهـا شـريك حياتـه المرغوب ، كعدم تقلده ذات الوظيفة العامة المتفق عليها ، أو عدم حيازته للخصائص

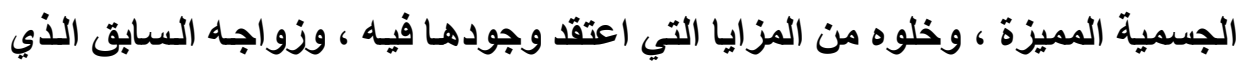
أكد الوسيط عدم حصوله ، ففي جميع أوجه التقصير السابقة ، لا يستطيع الوسبط إثبات

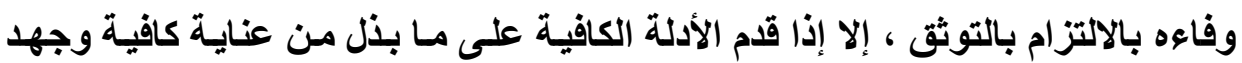
متكامل ، يوازي العناية والجها الذي يمارسه وسطاء النكاح من بني مهنته ومن هم في

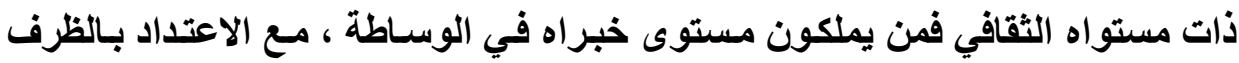
التي كاتت علاقة للتعاقد .

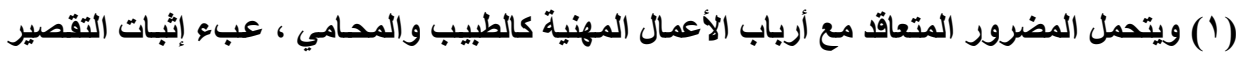

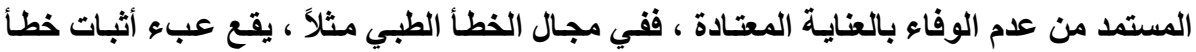

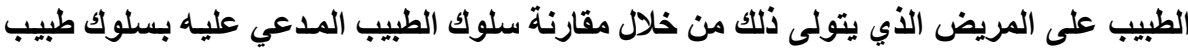

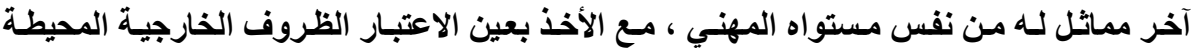

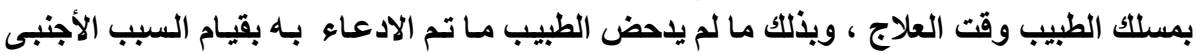

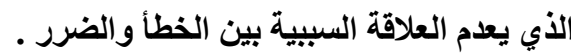

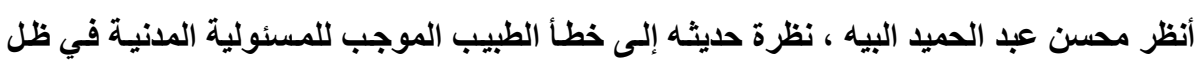

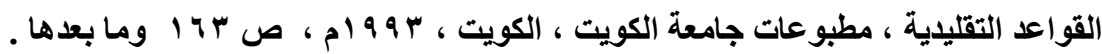

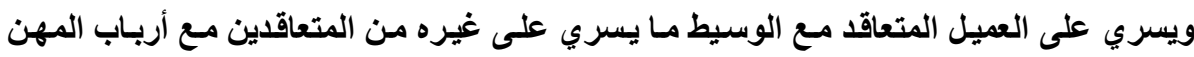

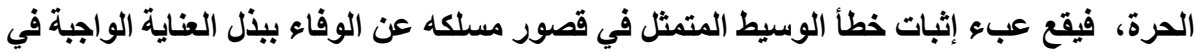
التوثق من صحة المعلومات والمستندات التي تقع في نطاق سمعه وبصره ـ 
ويعفى الوسيط كنلك من المسئولية عن الإخلال الذي قد يدعيه العيل فى جانبه،

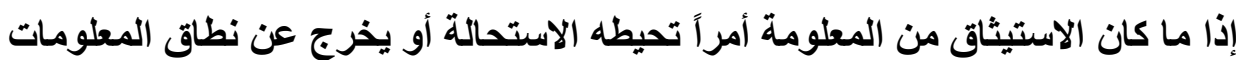

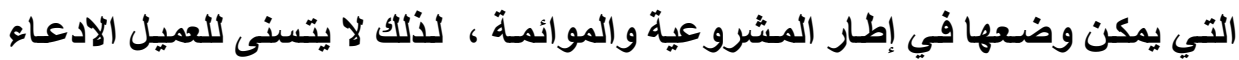

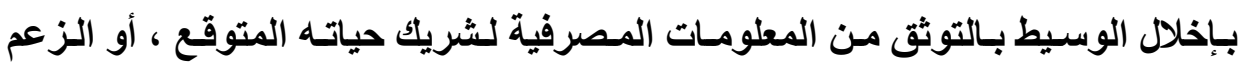

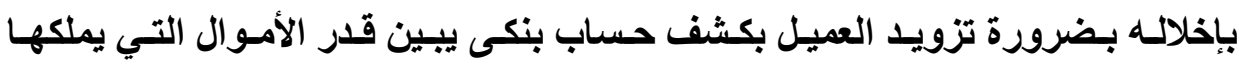

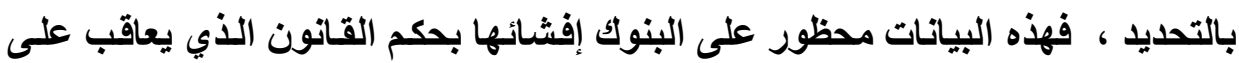

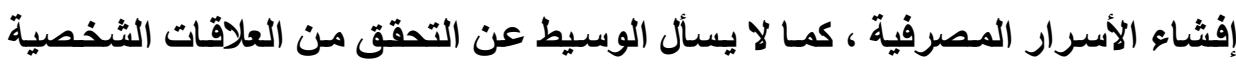

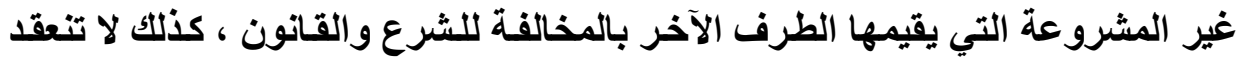

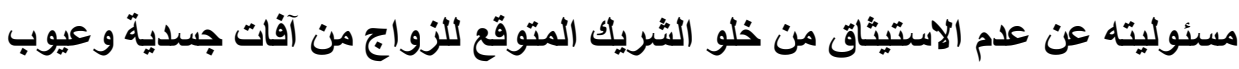

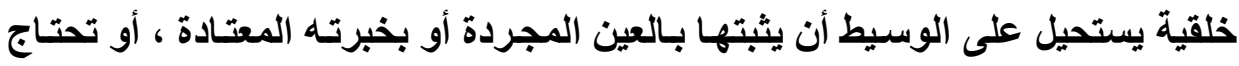

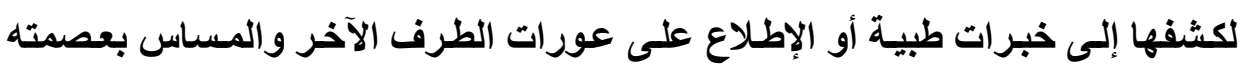

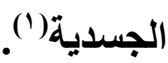

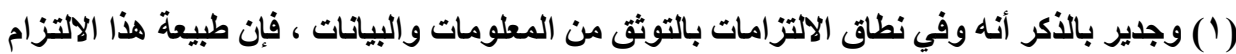

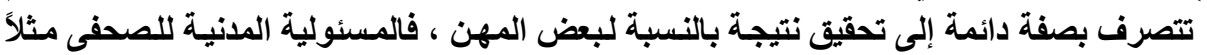

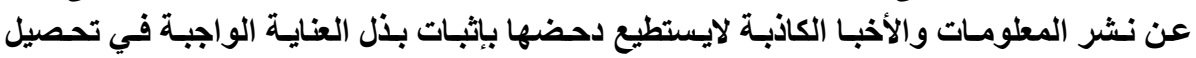

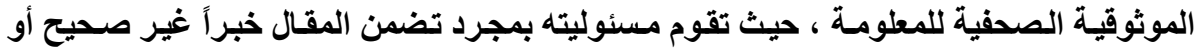

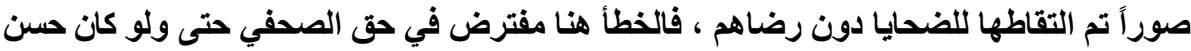

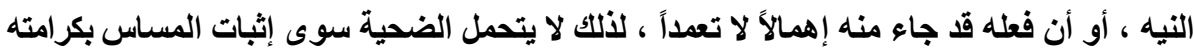

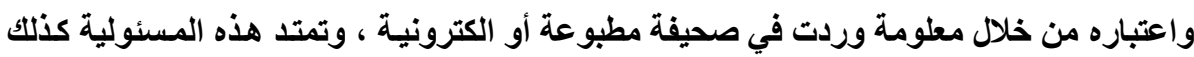

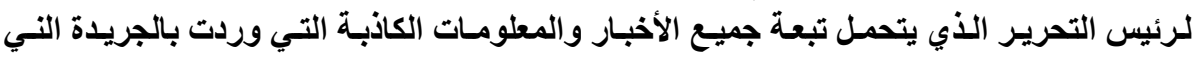

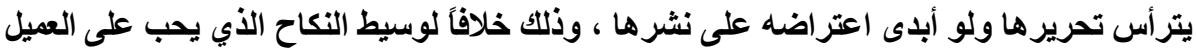

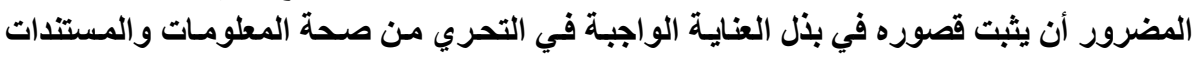
حتى تتوافر أركان المسئولية بثأنه .

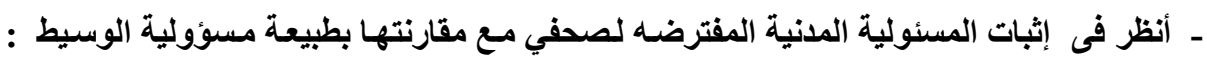

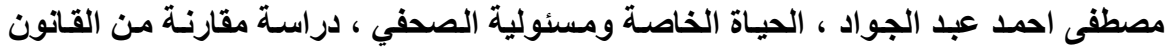

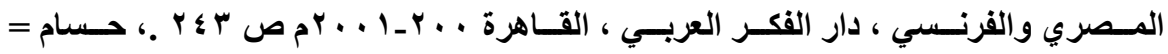


بيــ أن هنـاك طائفـة مـن المعلومسات الأسـاسية لا يمكن للوسـيط التخلص مـن مسئولية التوثث منهـا بطريقة سلسلة ، بـل يكون عبء إثبات الوفـاء بـالالتزام فيها عسيرا ، إذ لا يمكن القبـول بتقـير الوسـيط بواجب التوثثق مـن العـالتين المدنيـة والوظيفية للطرف المتوقع الارتباط بـه ، فهذه تعتبر من المعلومـات الأولية التى يقع على الوسيط عبئًا أساسياً من التحقى منها بمنتهى الدقة والتأكيا ، كما لا يتجرد مسلك الوسيط عن التقصير بواجب التوثق من الصفات الجسمية الظاهرة والتي يمكن إدراكها بالمطالعـة البصرية المباشـرة ، فهذه المعلومسات الأسـاسية وإن كانـت طبيعـة التزام الوسيط فيها لا تتغير في اعتبار وجوب قياس التوثق منها بأقيسة بذل العنايـة الواجبة للرجل المهني المعتاد ، إلا أن إدعاء الوسيط الوفاء بالعناية الواجبة فيها لا يمكن قبوله إلا بضوابط مُحكمة وبوسائل إثبات مشددة ، لذا فقد لا يستطيع الوسيط التخلص منها إلا بإثبات وقوعه تحت عوامل من الغش والتزوير الحاصل بفعل وتدبير الطرف الآخر ، أو ممارسـة وسـائل احتياليـة مُتقنـة إزاءه ممـا حجب عنسه وسـائل التوثـث بـشأن صـحة معلومـات أساسية ، وقد يضع القضاء بشأن هذا النوع من المعلومـات قرينـة العلم بها فى جاتب الوسيط بحيث يمكن أن يصل تصور عمله بها إلى العلم اليقيني المُفترض. ولئن كانت كافة الالتزامات التى تفرضها طبيعة مهنة الوساطة فى النكاح تدور جميعها فى رحى الرغبة فى إتمام عقد الزواج ، لذا فإنه يجب لإسباغ الصبغة الرسمية لهذا العقد الثرعى ومنحه القوة القانونية حتى ينتج آثاره فيمـا بين طرفيه منـذ مرحلة الوسـاطة ، أن يلتزم الوسـيط بـالتوثق مـن المبـادئ الأوليـة لأبـرام عقد الـزواج وأن

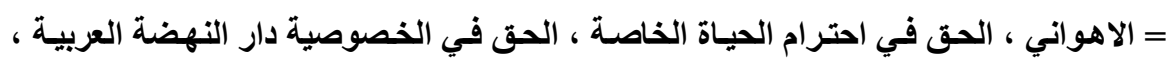

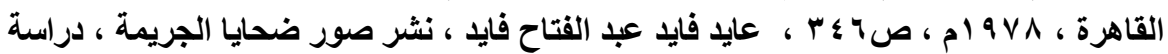

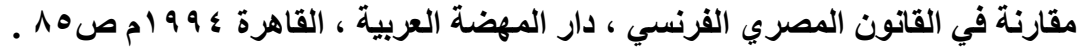


يضعها موضع التطبيق بالنسبة لعقد الوسـاطة الذى يوطئ لله ؛ كالالتزام بـالتحقى من شخصية طالبى الزواج ، والالتزام بالتثبت من توافر الأهلية اللازمـة للزواج فيهما ، وذلك من خلال الإطلاع على شـهادة الميلاد كوسيلة لإثبات سن الزوجين مـا لم يكن طالب الزواج يؤكد بلوغه السن القانونية ويظهر للوسيط صدقه فى ذلك من المطالعة البصرية المجردة ، فضلاً عن ضرورة التحقق والتأكد من قيام الصلاحية الموضوعية للأطراف لإبرام عقد الزواج بصورة تضمن عدم تعرضـه للإنحلال بـالتطليق لأسباب جوهرية مستمدة من أحكام الشريعة الاسلامية ، لذلك يجب على الوسيط أن يتحقق من خلو الزوجين من جميع الموانع الشرعية والقانونية وأن يحصل على إقرار صريح من طالبى الزواج بخلوهما من جميع الأمراض التى تجيز التفريق بينهما إذا مـا تم الزواج

كنتيجة للوساطة (1)

كمـا أنـهـ لا يؤدى قيسام الالتزام على الوسـيط بمراقبـة كل مــا يتصل بعلمـه مـن معلومات وبيانات ، أن تستطيل أعباءه المهنية إلى قياس كل معلومـة بمقاييس صسارمة

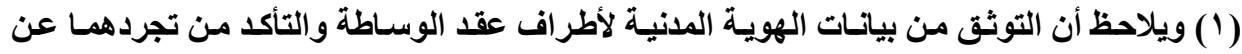

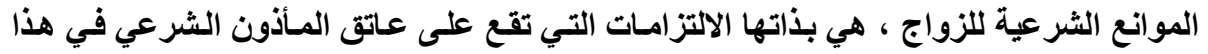

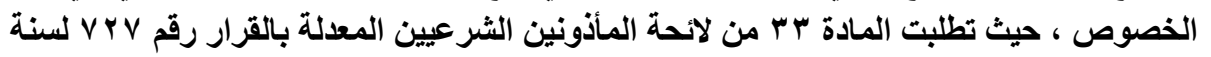

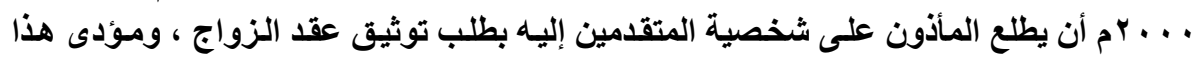

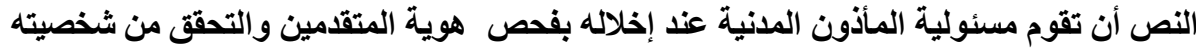

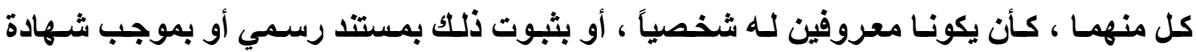

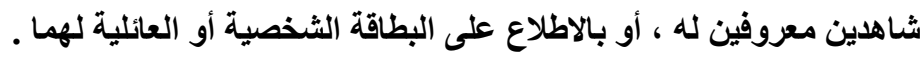

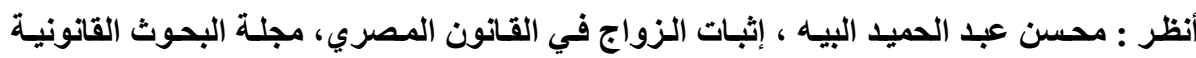

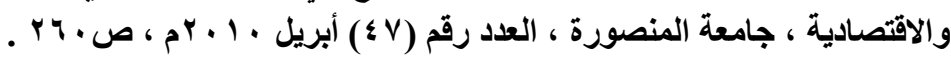

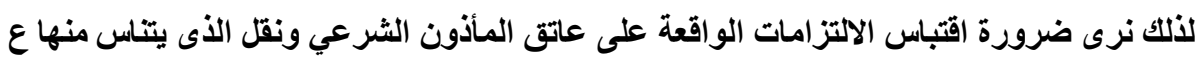

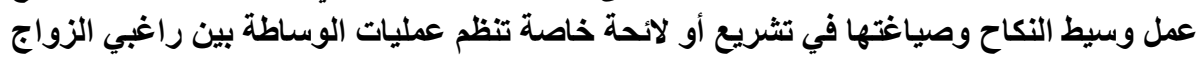

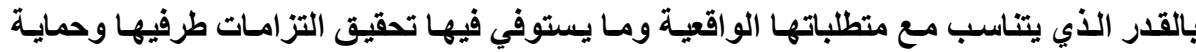
حقوقهم سواء أكان العميل أم الوسيط. 
من التحري والتدقيق ، ذلك لأن مـا قد يراه العميل مبالغة في جزئيسة بذاتها قد يكون مقبولاً عند آخرين من العملاء ، ولا شبهة في أن الراغبين في النكاح كثيراً مـا يلجئون إلى قدر من المغالاة فى إبراز وتحسين صفاتهم ولو كان قدراً يسيراً ، اعتقاداً منهم أن ذلكك يمثل نوعـاً مـن التجميل والتحسين الذي لا يندرج في نطـاق الغش أو التـليس المحظورين ، لـا فإن قدراً من التجـاوز يتعين التسامح فيسه عند تقدير حدود التزام

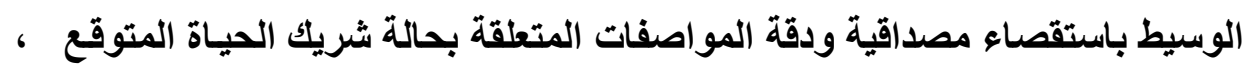
ويُعفى الوسيط من المسئولية بالنسبة لهذا القدر المُتاح من التجاوز في نطاق الالتزام

بالإدلاء بالمعلومات ورقابتها.

ومن صور هذا التجاوز الذي لا يُسأل الوسيط عن التوثث منـه بدقة ، الفروق البسيطة بين المراتب الوظيفية ، أو التثابه بين مرتبتين وظيفيتين ، كمن يخبر الوسيط أنه طبيب استشاري وهى فى الحقيقة طبيب أخصائي فى ذات التخصص الطبي ، أو كمن يخبر الوسيط أنـه وكيل لمدرسـة وهو يتقلد وظيفة نائب الوكيل ويوشتك ترقيتهـ لمنصب الوكيل ، أو كالأي يعلن للوسيط أنه مستشاراً قانونياً ويظهر أنه محامى حر لتقـارب الأمـرين وهكذاً ــويرجـع تقدير مسألكة التجـاوز المقبـول فـى مسألكة الصفات والمعلومات ، والتى ينعكس على عدم مسائلة الوسبط عن تقصيره فى واجب التوثث منها ، إلى السلطة التقديرية لمحكمة الموضوع ، التى يجب عليها أن ثُعل سلطتها فى لئ ضـوء الظروف والملابسـات التى تحيط عمليـة التوفيق مـع الاعتـداد بموقف العميل وجديته إزاء هذه المعلومات وعما إذا كان يعول على دقتها فى الارتباط بصاحبها من 


\section{المطلب الثالث}

\section{الالتزام بالتوفيق بين راغبى الزواج}

وبغرض الوفاء بشرح هذا الالتزام فإنها يجب تناولهه من خلال بيـان مضمون الالتزام بالتوفيق ونطاقه القانونى والطبيعة التى تظلب عليه ، وذلك من خلال الفرعين

الفرع الأول : مضمون الالتزام بالتوفيق.

الفرع الثانى : طبيعة وحدود الالتزام بالتوفيق.

\section{الفرع الأول}

\section{هضمون الالتزام بالتوفيق}

على المستويين الاجتماعي والفردي ، قد يؤدي الزواج من خلال وسيط إلى توسيع نطاق الاختيار وحسن انتقاء شريك الحياة المتوقع بطريقة تسهم فى تخفيف حدة

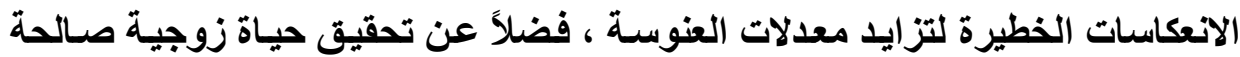

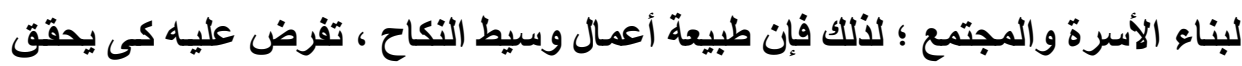

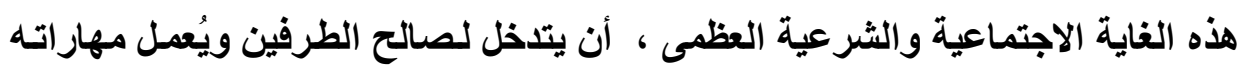

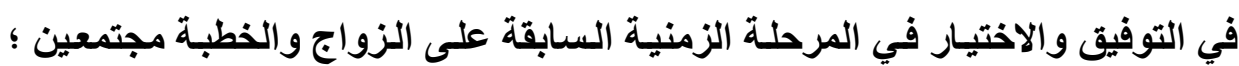
لأن عملية الوسـاطة تأتي غالباً في إطار التمهيد للاخول في فترة الخطبة التي تمثل فئل

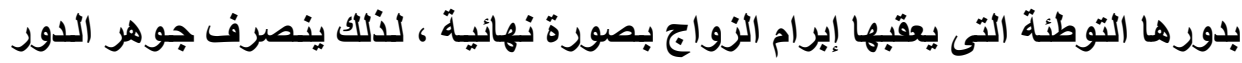

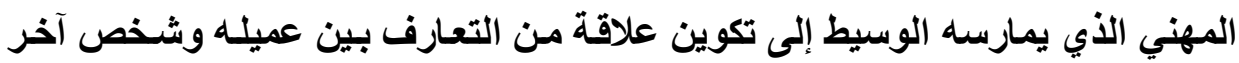

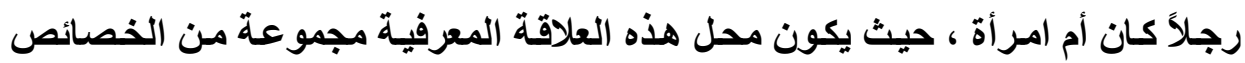
الثخصية والمواصفات الخلقيـة ، وكذلكت المعلومـات والبيانـات الماديـة والاجتماعيـة

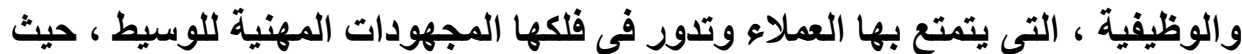


يبذل مساعيه لإقنـاع العميل المتعاقد معـه بتوافق صفات ومزايـا الطرف الآخر مـع مـا

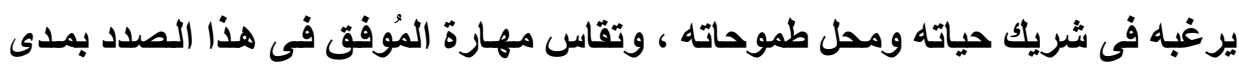

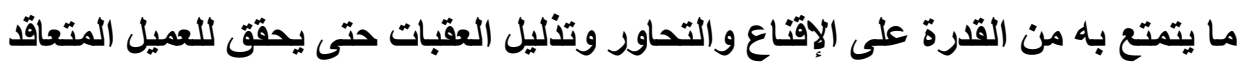

معه طموحاته الفردية وميوله المزاجية فيمن يرجو أن يرتبط به في زواج متوقع (') . ونتصور أن ينقسم الالتزام بالتوفيق إلى مرحلتين ، المرحلة الأولى منهما يمكن

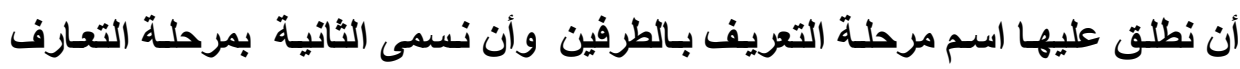

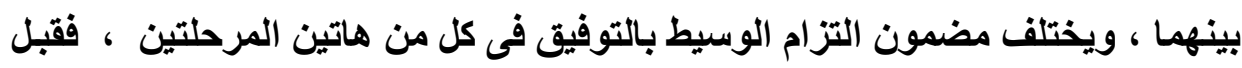

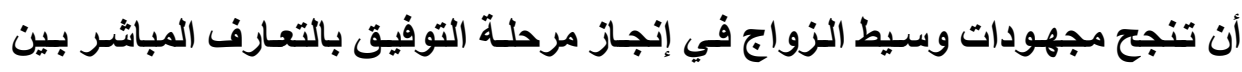

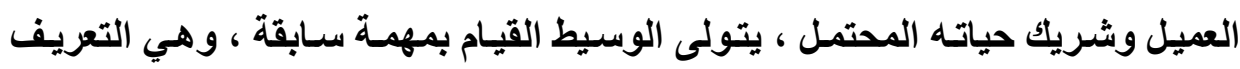
بشريك الحياة المحتمل ، وهو يعني عرض عام بمواصفات الرجل والمرأة وصفاتيهما

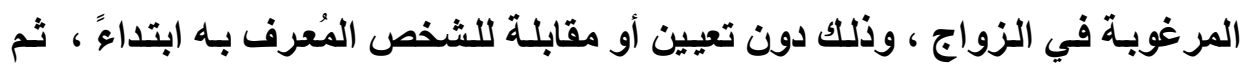

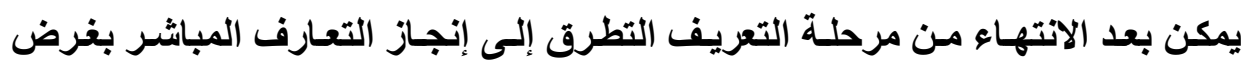

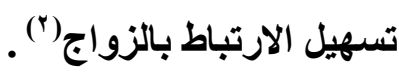

(1) ويقابل التزام الوسيط بالتوفيق في عقد السمسرة التزام السمسار بالتقريب بين وجهات النظر بين مصدر الأمر والطرف الآخر . مالوسئ

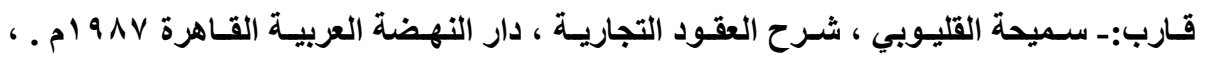

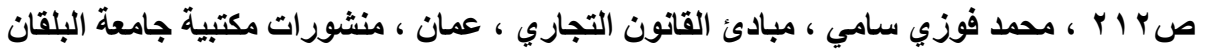

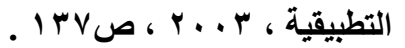

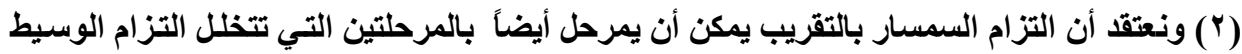

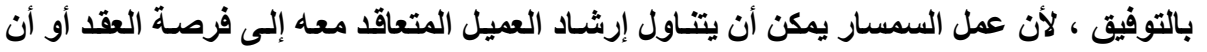

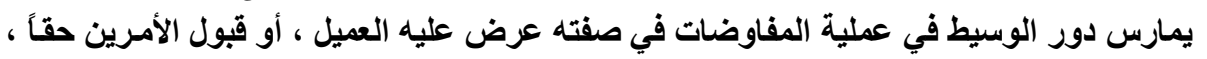

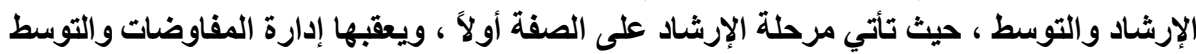
بين أطرافها بغرض إبرام العقد بشأنها .

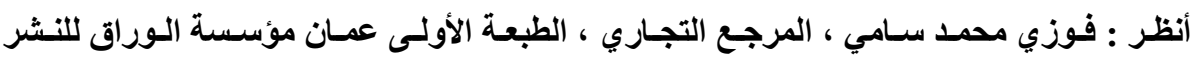

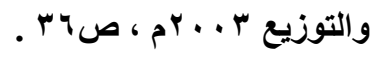


لذلك يقوم الوسيط ابتداءً بإنفاذ التزاماته العقدية في مرحلة التعريف بين طرفي الزواج المُحتمل ، وذلك عن طريق وصف الطرف الآخر للعميل وصفاً متكـاملاً ، من حيث بيان المواصفات المادية للطول واللون والوزن وغيرهـا من المواصفات المُحددة للصورة الحسية والموضحة للخلقة الطبيعة المجردة ، ثم يقوم في الغالب بتمكين العميل من الإطلاع على الصورة الفوتوغرافية للطرف الآخر الذي سلمها إياها بغرض عرضها على العميل لتسهيل عملية التوفيق ، ومن ناحية آخري ، يتولى الوسبط نقل الصفات الخلقيـة والمعنويـة لعميله إلى شـريك الحيـاة المتوقع ، ويتولى الوسبط كذلك مهمـة

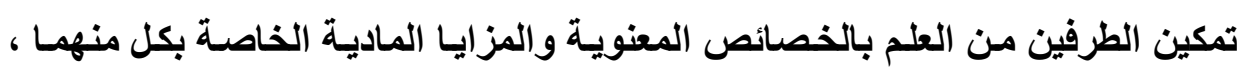
فيبين لكليهمـا حقيقة مـا يتمتع بـه الطرف الآخر من حيث ملاعتـه الماليـة ووظيفته

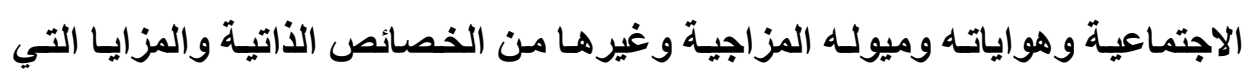
تهيئ للعميل إدراك طبائع الطرف المقابل وظروفـه العامـة والخاصـة حتى يتمكن مـن إبداء الرضا لاستكمال المرحلة الثانية من التوفيق وهى مرحلة التعارف المباثر بين

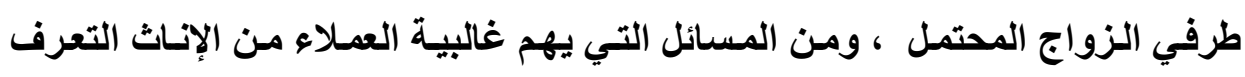
عليها فى نطاق مرحلة التعريف والتي غالباً مـا يحرص الوسبط والمرأة على التذكير

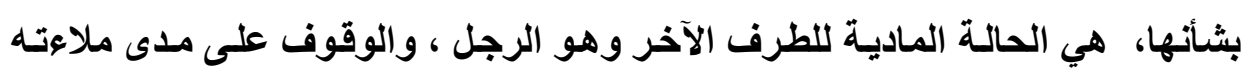
المالية لتحمل أعباء الزواج ومسئولياته الجسام ، حيث تدور أغلب المفاوضـات حول هذه المزايا المادية ، وهو ما يلقى التزامساً على الوسبط بضرورة تبيان المسائل التى ألى تمثل أهمية بـارزة للعميل ، وإلا اعتبر مقصراً بالوفـاء بـالالتزام بـالتوفيق فى مرحلـة التعريف بين عميله وشريك حياته الاحتمالي.

وفى نطاق المرحلة الثانية من الالتزام بالتوفيق ، تأتي في نهاية المطاف الحلقة الأخيرة من مراحل تنفيذ هذا الالتزام التعاقدى ، وهي التي يُمكن فيها الوسيط أطراف 
العلاقـة الزوجيـة المرغـوب إبرامهــا مـن اللقــاء المباثـر والتجـالس بغـرض الروئيـة والإطلاع التلقائي لخصائص وصفات الطرف الآخر من حيث الخُلث والخلقة ، ويتولى الوسيط فى تلك المرحلة دوراً يفصح فيه عن أقصى مهاراته المهنية ، فيبذل في سبيل تحصيل الانسجام بـين الطرفين كـل مـا يملـك مـن مهـارات وبراعـة الإقــاع الطرفين

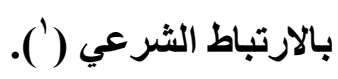

\section{الفزرع الثاني}

\section{طبيعة الالترام بالتوفيق بين راغبى الزواج}

كما سبق البيان فِإن وسيط التوفيق بين راغبي الزواج يتولى القيام بالتزام عقدي مضمونه إنشاء رابطة للتعـارف بين رجل وامرأة بقصد إحداث الألفة والقبول فيما بينهما ، وبغرض الدخول في علاقة النكاح الشرعي ، ويُقصد بالتعارف في هذا

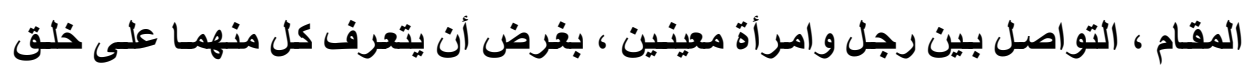
الآخر وأن يتفحص صورته الجسمية ، معرفة تؤدي إلى حسن الاختيار من أجل حصول الزواج فيما بينهما.

ويستخدم الوسيط في سبيل إنشاء رابطة التعارف بين عميلين ، مجموعة من الوسائل ، ولا شك فإن الوسيط وهو يتبنى إحداث التقارب بين الطرفين وخلق حالة من

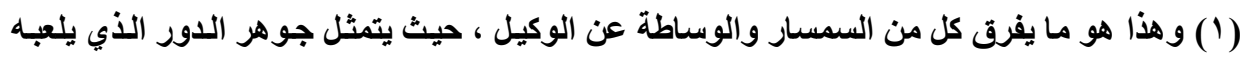

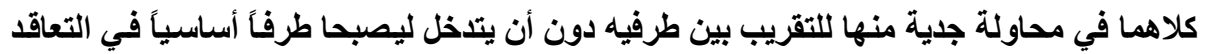

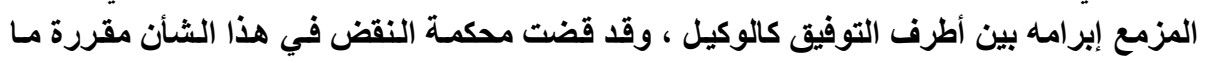

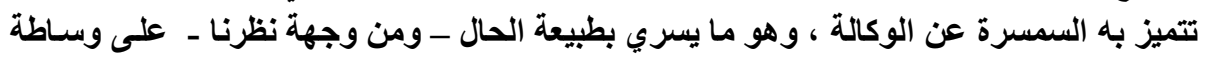
النكاح . النيز

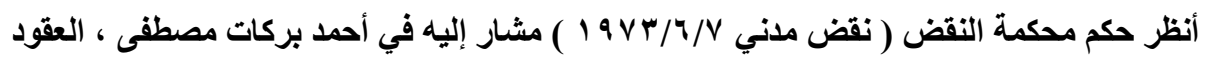

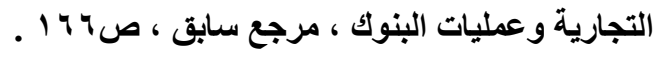


الانسجام بيزهما ، فإنـه لا يملك السلطة القانونيـة لإجبار الطرفين على قبول بعضهما البعض ، إنما تنحصر مهمته في استقبال الأطراف الراغبة في الزواج والإنصات إليها وتوسيع قاعدة التعارف فيمـا بينهمـا ، وبذل المحاولات الممكنة لحل الإشكاليات التي تعترض حصول عملية القبول والارتباط ، لذلك يكون من الإتصاف ألا يتحمل الوسبط في هذه المهمة الثـاقة التزامًا بإيصال الطرفين إلى نتيجة محددة تحسم فكرة الزواج لـديهما ، فضلاً عن أن مسألة القبـول الحـر المستتير للـخول في رابطة الززواج الثرعية ، تتعلق بمحض مزاج شخص للعميل بحيث يستعصى على الوسبط أن يظفر بقبول العميل دون أن تتكون للى الأخير قناعة شخصية كاملـة بقبول الطرف الأخر

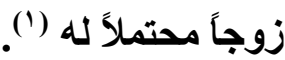

ولا شك فِان المستوى المهني الذي يتمتع بـه الوسبط لابـ أن يكون ذو تأثير خـاص على إنجـاز عمليـات التوفيق ؛ فالوسيط البـارع ممن يملكون مهارات الإقــاع والقدرة على انتقـاءع العبـارات الجاذبـة والحديث الشيق والمقارعة العقلية ، يكون لـه السبق في تحقيق نتائج بـاهرة في عملية التوفيق ، ويكاد يبحث جميع الراغبين في الزواج عن هذه الطائفة من الوسطاء المحترفين ، بوصفهم يمثلون بالنسبة إلى العميل المُفوض المحترف فحى التعبير عن رغبـتهم بمهارة فائقة وإبراز مـا يتمتعون بـه من مزايا والعمل على إخفاء مـا قد ينتقص من شأنهم في نظر الطرف الأخر.

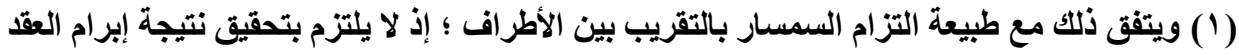

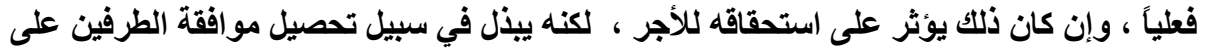

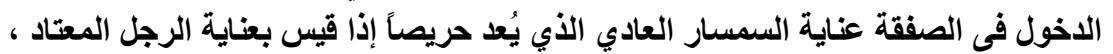

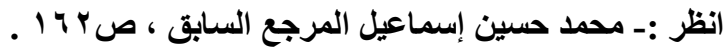




\section{الإطباب الرابع \\ التزام الروسط بالسرية}

\section{الفرع الأول}

\section{هضمون الترام الوسيط بالسرية}

يُعرف السر إصطلاحاً بأنه الواقعة التي ينحصر العلم بها في نطاق عدد محدود من الأشخاص إذا كان هنائ ثمة مصلحة يقرها القانون لأن يظل العلم بها محصوراً في هذا النطاق المُحدد (') ويُعرف الالتزام بالسرية في المجال التعاقدي أنسه الالتزام الذي يقع على عاتق المتعاقد والأى يتعهد بموجبه بألا يفشي المعلومات والبيانات التي تصل إلى على أثناء التعاقد إلى الغير(') .

ويحتل الالتزام بالسرية مكانـاً بـارزاً بين الالتزامسات التعاقديـة لوسيط التوفيق

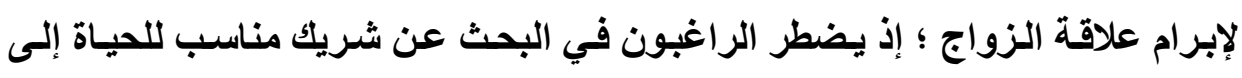
الإدلاء بمعلومـات وبيانـات غايسة في السرية والخصوصية ويقوم الوسبط بتلقي هذه المعلومسات ويسجلها لايـة حتى يتمكن من إجراء البحث المطلوب إستنـاداً على تلكت المعلومــات والأسـرار الخاصـة التـي تـم تزويـــه بهـا ، وفي الحقيقـة إن طبيعـة المهــة الموكولة إليه تنطلب إمداده بجميع المعلومات الدقيقة عن الطرف الراغب في الزواج ، وضرورة تزويدة بخصائص الثخص الأي يتمنى العميل الارتباط به كذلك ، حيث يقوم الوسيط بـدور مـزدوج في المهمـة التـي ينـاط بهـا ، فيتولى مـن ناحيـة بـذل المسـاعي (1) محمود نجيب حسني ، قانون العقوبات ، القسم الخاص ، درا النهضة العربية ،القاهرة 1911 م ،

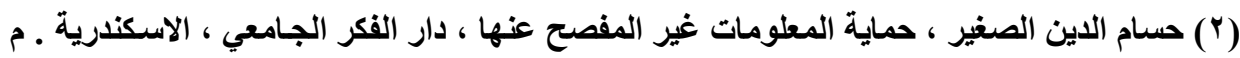


الحقيقية للحصول على شخص يتمتع بالصفات المحددة من العميل ، ثم ينهض إلى إقناع هذا الأخير بالمعلومات والصفات للطرف الراغب في الارتباط به. ولبيـان ذلكك بـصورة أدق ، فِإن التزام وسيط التوفيق بالمحافظة على السر المهني والامتناع عن إفشائه لهو من أهم الالتزام القانونية لهذه المهنة ، فالر اغب في البحث عن شريك الحياة يودع جميع أسراره الثخصية المحضة لدى الوسيط الموفق ، فيطلعـه مضطراً على أدق الخفايـا التـي تكتنف خصائسصه الذاتيـة وخواصـه المزاجيـة وميوله ومهاراته ، وقد يصل الأمر إلى أن يطلب راغب الزواج من وسيط التوفيق أن يخفي على الطرف الآخر بعض الأسرار التي أبـاح بها للوسيط حتى يتمكن الأخير من تحصيل زوج المستقبل دون معوقات قد تسبب في نشوئها معلومـة معينة يرى راغب الزواج ضرورة طمس معالمهـا وإخفـاء وجودهـا لئلا تشكل مانعاً من حصول الارتبـاط الشرعي بزوج المستقبل المناسب.

لذلك يجب على وسيط التوفيق أن يمثل الحسارس الأمين على رصيد المعلومـات

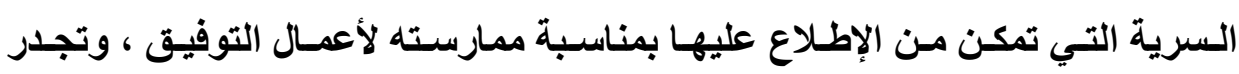
الإشارة إلى أن التزام وسبط التوفيق بالحفـاظ على السر المهني لا يترتب على العقد المبرم مع راغب الزواج مباشرة ، إنمـا نـرى أنـه التزام أصبل تفرضـه قواعد ممارسـة مهنة التوفيق بحسبها تقوم في جوهرهـا على أعمال ذات طابع اجتمساعي محض ومـا يفرضــه ذلـك مسن التطرق إلـى صـميم المعلومسات السرية لأطرف العلاقـات ، بحيـ يستعصي على وسيط التوفيق الوفاء بالتزامه بالبحث عن شريك ملائـم للحيـاة الزوجية إلا بعدما يـتمكن مـن الإطلاع الشامل على جميع خصائص راغبي الزواج وظروفهم الصحية والاجتماعية والمادية بمنتهى الدقة والمصداقية . 
وإذا كانت جميع المفاوضات والالتزامات التى تنشأ بموجب عقود الوساطة تقوم على جـوهر تـداول المعلومسات والبيانـات ذات الطـابع الثخـصي والاجتمـاعي وتمتــاز أغلبها بالسرية ، لذلك يكون مـاتح المعلومـات حريصاً على ضمان عدم إفشاء هذه الأسرار سيما وأنها تتعلق بأدق خصوصياته التي لا يرغب في أن يطلِع عليها أحداً إلا

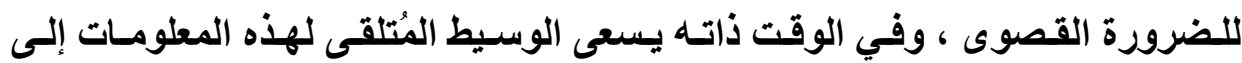

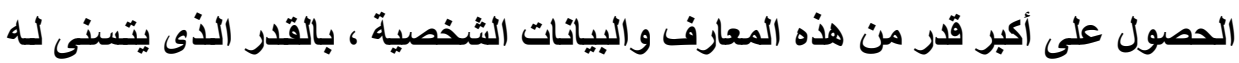
دراسة تفاصيلها وجزئياتها ، وبغرض تقييم قرتهـ على تحصيل الصفات المطلوبـة ، وكيفيـة إدارة الحـوار ومهـام الإقتـاع وصـولاً لإحـداث الانسبجام بـين الطرفين وإتمسام

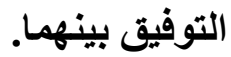

ومـا بـين تعـارض المـصالح بـين الوسـيط المتلقـى والعميل المساتح للمعلومـات والرغبات الثخصية ، ينشأ الالتزام بالحفاظ على السرية ، وهذا الالتزام يقع بالدرجة ولهئ

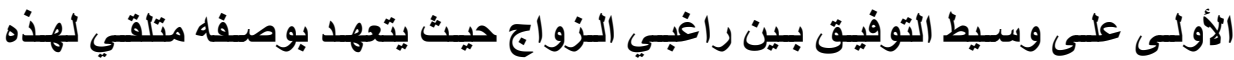

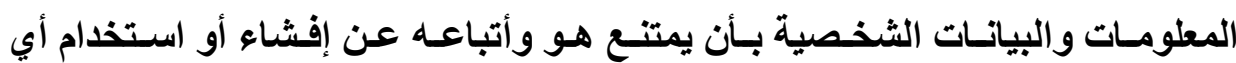
معلومسة تتسم بطابع السرية ، حيث يشكل هذا الالتزام أهميـة كبيرة في مجـال العقد

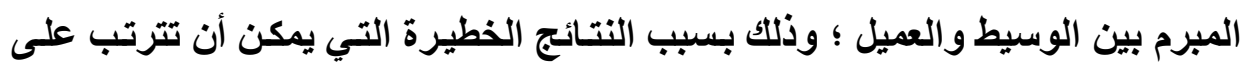
الإخلال بهذا الالتزام بوصفه يُشكل العمود الفقري لإتمسام مهمة الوسـاطة بين الراغبين في تحصيل شريك مناسب للحياة الزوجية(')

(1) وينبثق الالتزام بالسرية وبصفة عامة عن الحق في احترام الحياة الخاصة ، وهو وهو حق مقرر لكل

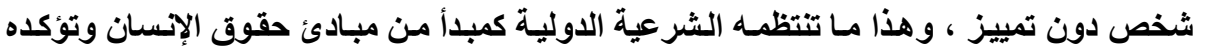

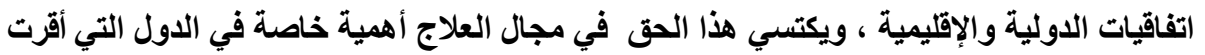

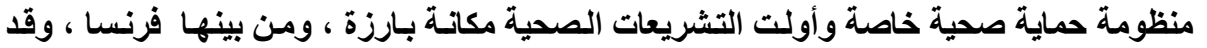

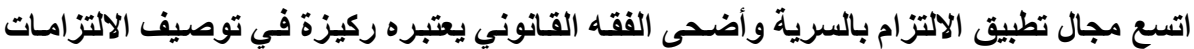

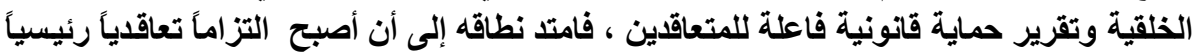

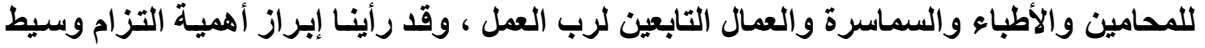

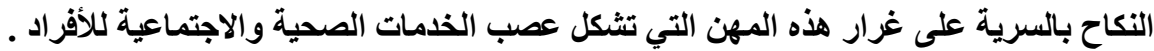




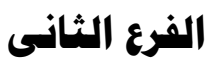

\section{الأساس القانوني لالتزام وسيط التوفيق بالسر المهني}

يمكنتا بيان أساس التزام الوسيط بالسرية من خلال تناول الأسس التي نـادى بـه

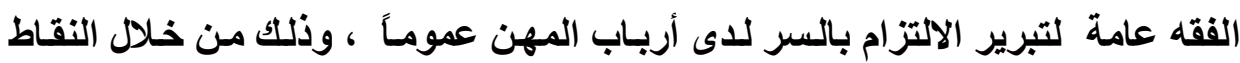
التالية:-- (1) - n

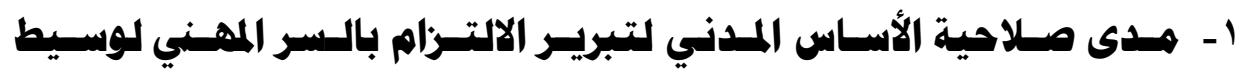

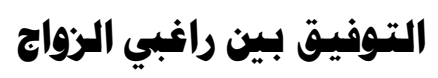

ويتمثل الأساس المدني للالتزام بالسرية المهنية في اتجـاهين رئيسيين يتمثثلان

في العقد والمسؤولية التقصيرية وكلاهما يندرج في نطاق المصادر الأسـاسية للالتزام

$$
\text { في القانون المدني . (1) }
$$

ومن حيث ما سبق وأن انتهينا بصدده من اعتبار العلاقة التي تنشأ بين وسيط

التوفيق والعميل الراغب في الزواج علاقة تقوم على التقاء الإرادة التعاقدية لاحداث أثر

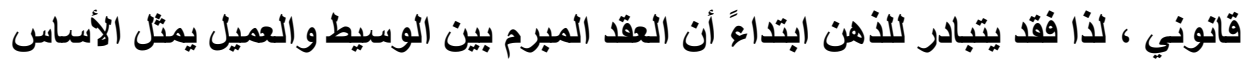
المقبول لتبريـر التزام الأول في الامتــاع عن الإفضاء بالمعلومـات التـي تلقاهـا مـن الأخير، ومن منطلق هذا التصور ، فأن أسساس الالتزام بالسر المهني لوسيط التوفيق

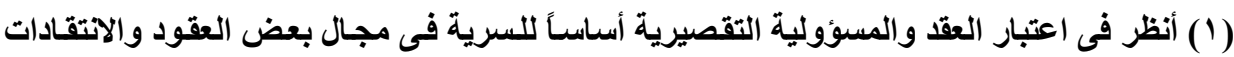

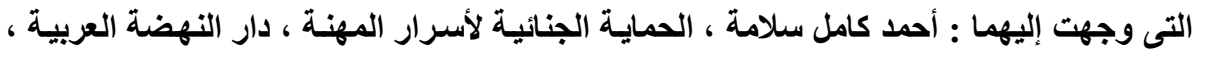

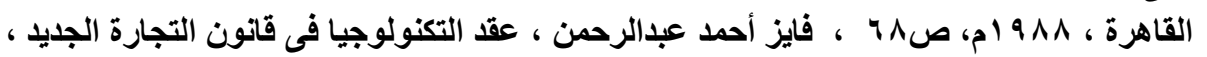

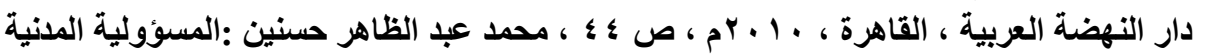

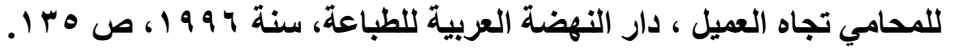


تجاه العملاء من راغبي الزواج يكمن في ما يمليه عقد الوساطه المبرم بينهما الذي يُعد وفق هذا التصور المصدر الرئيسي لالتزام الوسيط بالحفاظ على هذه الأسرار المعهود

لكنـه ومـن جانبنـا لا نـرى أنـهـ ، وخلافاً للانتقـادات التـى وجهت لنظريـة العقد كأساس للسر المهنى ، فإن العقد لا يصلح الأسساس السليم للالتزام بالسرية في مجال

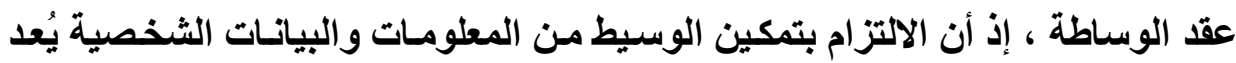

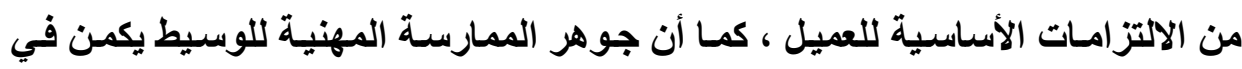
عملية نقل المعلومات من طرف إلى أخر ثم يتولى الوسيط تدوير هذه المعلومات ونقلها

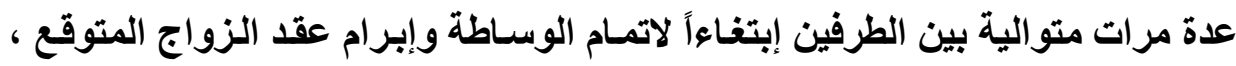

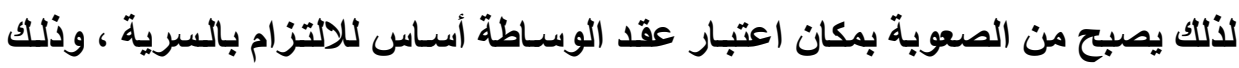

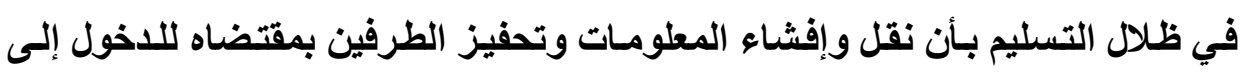
علاقة الزواج يمثل الأساس المهني والجوهر الذي تقوم عليه مهمة الوسـاطة ذاتها ، حيث تتبلور في عملية نقل وتداول المعلومات الثخصية ، فعقد الوسـاطة إذا يقوم على

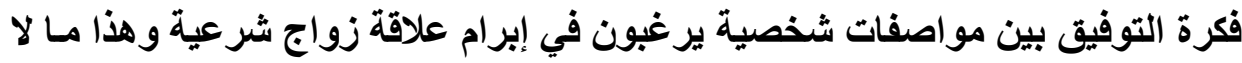

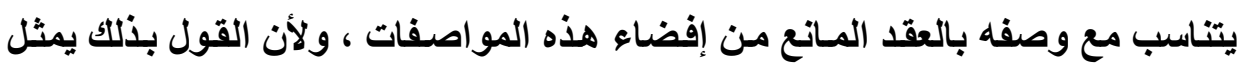

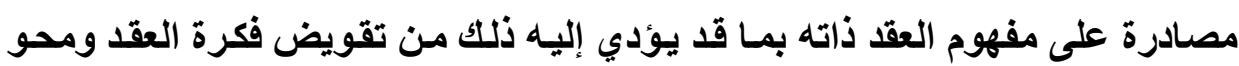

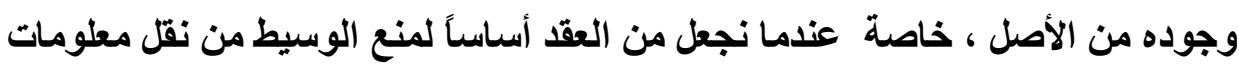

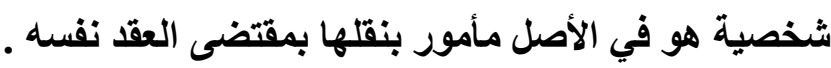
ولم تكن المسؤولية التقصيرية بحال أفضل من سابقتها العقدية ، إذ العمل غير

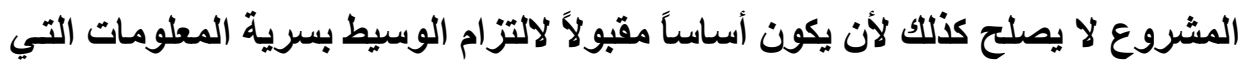

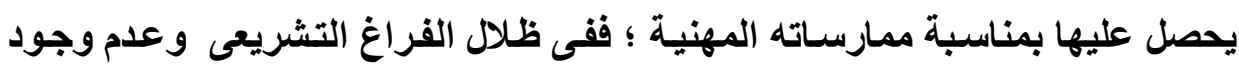
الضوابطو الأحكام القانونية التي تنظم مهنة وسيط النكاح ، فبان ذلك يؤدى إلى انتفاء 
القواعد القانونية التى يجب على وسيط التوفيق الالتزام بمضمونها القانوني ؛ لذلك لا

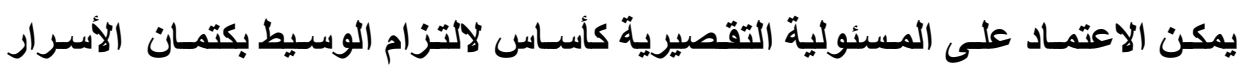
الشخصية طالما أن الإفضاء بمعلومات العميل لا يشكل مخالفة قانونية إنتظمها المشرع

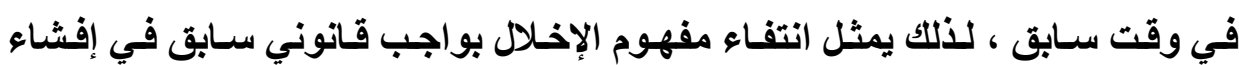
الوسيط بأسرار عملائه مانعاً من اعتبار مسئوليته التقصيرية أسـاس للالتزام بالسر

لكن هذا المانع القانوني لا يحول بديهياً من قيام المسئولية التقصيرية لمُوفق الوسـاطة الزوجيـة إذا مـا تـم تناقل المعلومـات والبيانـات الشخصية في دائرة الأعمـال المُؤثمة جنائياً ، فقل يعاقب القانون الجزائي على ارتكاب صوراً تثكل جرائم منصوص إنص

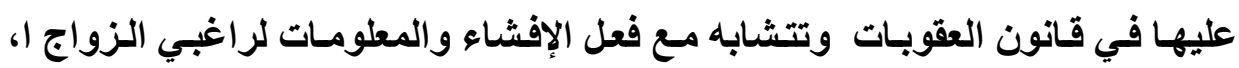
لألك إذا تطابق مضمون الفعل الذي يصدر عن موفق الوسـاطة الزوجية مـع النموذج القانونى لأركان الجرائم الموصوفة بالتشريعات الجزائية ، فإن مسئوليته عن التعويض لهون تقوم في حالـة صدور حكم جنـائي يحوزه قوة الأمـر المقضي يتضمن إدانـة لموفق الوسـاطة استتـاداً لإفشاء معلومـات وبيانـات العمـلاء الذي اتخذ صسوره مؤثمـة يعاقب عليها القانون الجنائي ، وذلك كجرائم السب والقذف والتحريض على الفسق والفجور وغيرها من الصور الأجرامية الأخرى ـ ونئ

r- هـدى صسلاحية فكـرة النظـام الهـام لتبريسر التــام وسـيط التوفيـق بالسرية: - بال

إزاء قصور نظرية العقد كأساس للالتزام بالسر المهني ، وأمسام الانتقـادات التي

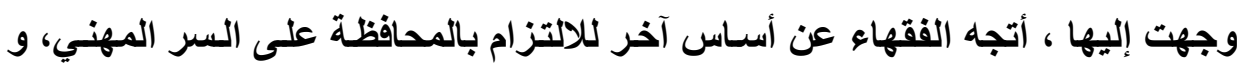

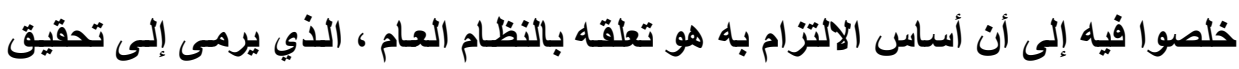


المصلحة الإجتماعية ومقتضيات المصلحة العامـة ، لذلك أتجـه الفقه إلى الأخذ بفكرة النظام العام لاستجلاء الأسـاس القانوني للالتزام بالسرية المهنية لأربـاب بعض المهن

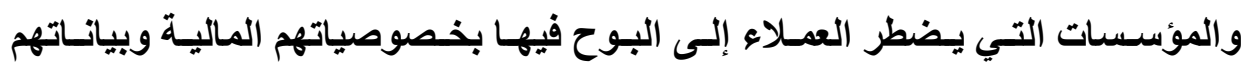
الشخصية ، كالطبيب والمحامي والبنوك وغيرهم ، ويتمثل مضمون هذا الأسـاس فى لـ لهي أن الالتزام بالسرية يجـد مسصره فـى ضـرورة ضـرورة حمايسة الـصالح العـام للـنظم

الاجتماعية والاقتصادية والسياسية. (1)

ونحن نرى فى النظام العام أساسـاً مقبولاً لحمايـة سرية العملاء والحفـاظ على حقوقهم وحرياتهم الشخصية ، خاصة مع استقرار الرأى فقهاً وقضاعاً على أن الحريـة

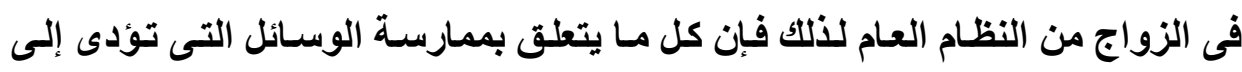
إبرام الزواج كالوساطة فى النكاح يكون متعلقاً كذلك بالنظام العام الآمر بحيث يلتزم الوسيط بتحقيق المصلحة العليا للمجتمع بأن يمتنع عن أفشاء أسرار من يقبولن على مرحلة الزواج من العملاء المتعاقدين معه حيـث يــعكس الإفـضاء بأسـرار العمـلاء الثخـصية علـى المسساس بـالنظم الاجتماعية لما يثكله ذلك من خطر اجتمـاعي عام مستقل عن النتائج التي قد تحدث الته للشخص صاحب السر، فالمشرع لا يتلخل لحماية مصالح خاصة أو بهدف ضمان تنفيذ اتفاث بين الأطراف إنما راعى ضرورة حماية النظام العام الإجتماعي ، لذلك فإن ترسيخ احترام الخصوصية مبدأ رئيسي في الممارسة المهنية لوسيط النكاح ، فيجب من خلاله

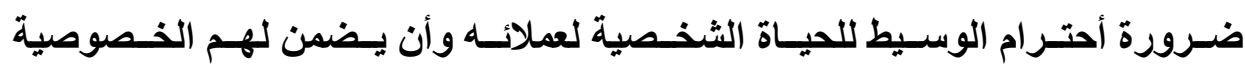

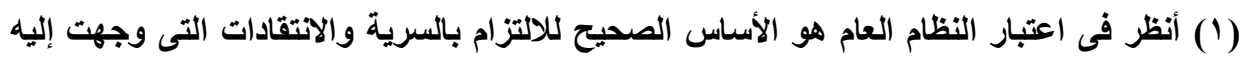

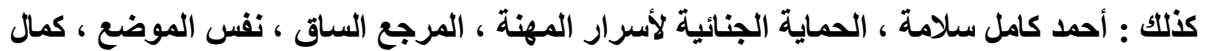

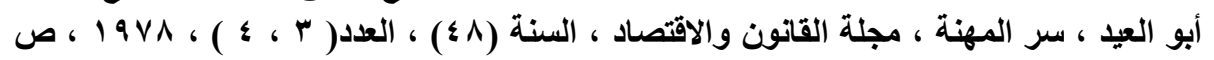

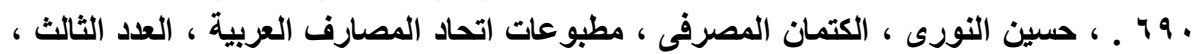
. r. liqr 
والكتمان، وألا يتوسط في نشر أسرار العميل بدون إرادة من صـاحبها وإذن منـه إلا إذا كان ذلك يحقق النظام العام أيضاً وهو أمر متروك تقديره للمحكمة ، ويظل بذألك سر لـر

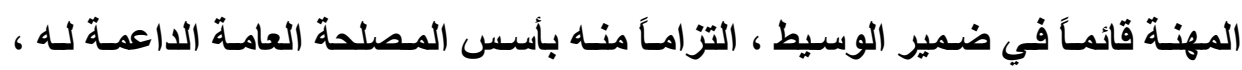
وبالتالي يمتنـع عيه الإفشاء بـه نتيجة لخضوعه للضغط أو الأكراه و الابتزاز ، طلبـاً لإفشاء أسرار عملائهـه أو الكشف عن مصادر معلوماتـه عنهم ، الأمر الذي يستدعي

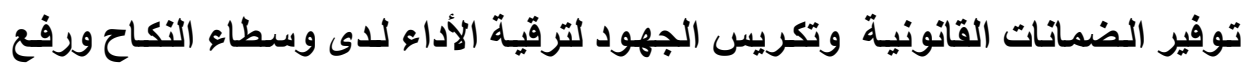
مستواهم الثقافي والمهني والخُلقي ، مع ضروة صياغة لائحة أو قانون خاص ينظم

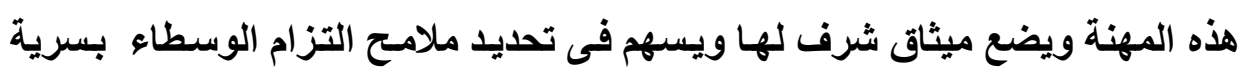
معلومات العملاء.

\section{الفرع الثالث}

\section{حدود الترام الوسيط بالسرية}

جدير بالذكر ، أن التزام التوفيق بعدم بالإفضاء بالسر المهني قد يتـاقض مـع

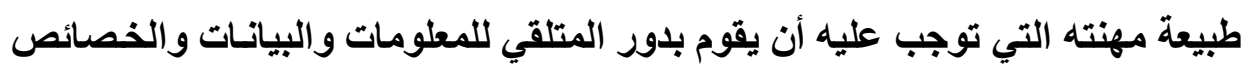
الذاتية لراغبي الزواج ثم يتولى نقلها والبوح بها للطرف الآخر بحكم صميم الطبيعة

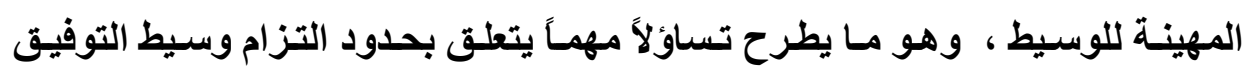
بسرية المعلومسات في علاقته بـأطراف رابطة الزواج المتوقع إبرامها في المستقبل

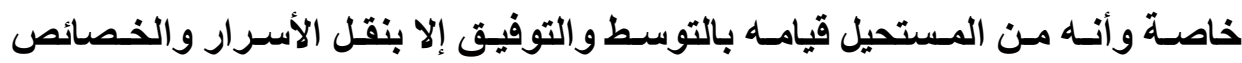
والبيانات الشخصية من طرفي العلاقة المتعاقدين معه بغرض التوفيق بينهم فى زواج

احتمالى.

ومن جانبنـا فإنتـا نـرى أن التزام وسبط التوفيق بالسرية التامسة وأن كـان يقوم

بصفة أصلية في صورة الالتزام بالامتنـاع عن الإفضاء بأيـة معلومـات أو بيانـات أو

Q مجلت البحوث القانونيت والإقتصاديت 
خصائص لغير الأطراف المتعاقدين معه ، و إذا كان ذلكك يمثل جوهر التزامـه بعدم نقل

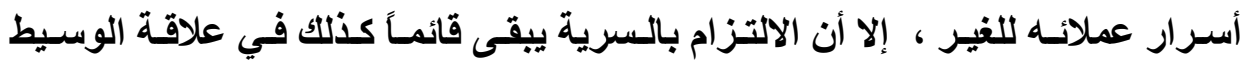
بأطر اف الزواج المتوقع إبرامـه ، بحيث يلتزم الوسيط بالامتنـاع عن نقل أى معلومـة

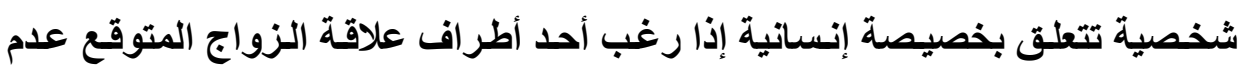

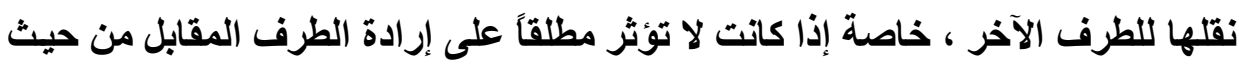
دفعه لأبرام عقد الزواج ، وذلك مثل المعلومـات المتعلقة بهوايـات الطرفين الثخصية مثل هواية العزف على الآلات الموسيقية أو جمع الطوابع أو اللوحات والمقتتيات الثرية وغيرهـا من المعلومـات ذات الشبة ، حيث إن هذه الخصائص والهوايـات ليست من الخصائص الأساسية للمرأة والرجل بحيث ينتفي عن الوسيط الالتزام بنقلها للطرف الآخر في سبيل تنفيذ التزاماته التعاقدية على أحسن وجه ، ومن حيث أن الوسيط غير ملتزم من الأصل بنقل هذه الخصائص الأتيـة لأنها خصائص ثانويـة في التأثثر على الإرادة بدفعها أو بعزوفها عن إبرام الزواج المتوقع ، لذلك ينشأ على الوسيط التزامـاً بالسرية إزاء هذا النوع من المعلومات الثانوية طالما لم يتلقى إذناً من صساحبها بنقلها للطرف الآخر بهدف ترغيبة في إبرام الزواج ـ والعلة مما تذهب إليه في هذ الصدد ، أن هئ

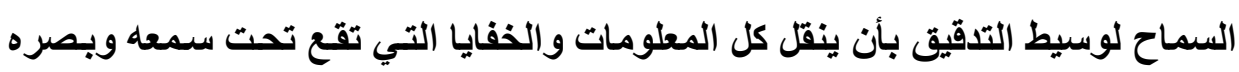
بمناسبة ممارسة مهام التوفيق ، سوف يترتب عليه مخاطر كبيرة تنتج عنها قيام حالة معرفية شاملة لاى أحد الأطر اف بجميع خصائص وبيانـات ومعلومـات الطرف الآخر ، الأمر الذي قد يؤدي إلى استغلال أياً من الطرفين لهذه المعلومات واستخداماها بصورة غير مشروعة في الأضـرار بـالطرف الآخر وهو مـا يكون لـه انعكاس على الإضرار بالمصلحة الاجتماعية ككل ، خاصة إذا تعثرت عملية التوفيق بينهما وبـاعت بالفشل ، فقد يسعى الطرف المتلقي لهذه المعلومات إلى التأثير على علاقة الزواج التي أبرمها الطرف الآخر مع شخصية أخرى نجحت عملية التوفيق بينهما من خلال وسيط آخر أو 
بطريقة أخرى ، أو قد يقوم بتشويه سمعة الطرف الآخر والمساس بوضعه الاجتمـاعي من خلال إثاعة هذه المعلومات وعرقلة ارتباطه بطرف أخر ، وحتى إذا نجحت عملية التوفيق بالزواج بين الطرفين فقد يستخدم أحد الزوجين هذه المعلومات وسيلة للسيطرة المادية والمعنوية على الزوج الآخر خاصة إذا كاتت تتعلق بأسرار مرتبطة بمزايا ماليه أو بحالة مزاجية أوبميول نفسية أو جنسية لأحد الزوجين(').

ولا يفوتنا التتبيه ، بأنه ليس من اللازم أن تكون جميع المعلومـات التي يحصل عليها مُوفق الزواج تلخل ضمن نطاق السر المهني(r) ، بل يجب أن تكون هناك حدوداً وفواصل بين ما يمكن اعتباره سراً مهنياً يمتتع عن الوسيط إفشائه ومسالا يُعد من هذا القبيل ، وفي هذا الصدد فإنتا يمكنـا التفرقة ببين مستويات ثلاثة للسرية يمكن التميز

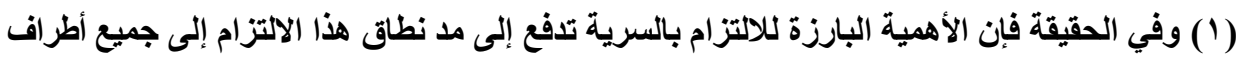

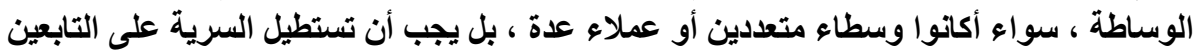

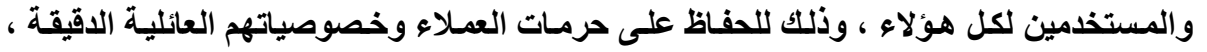

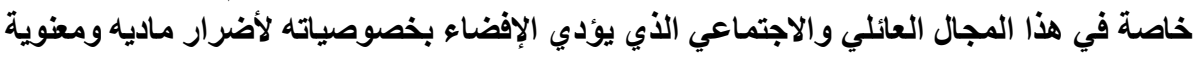

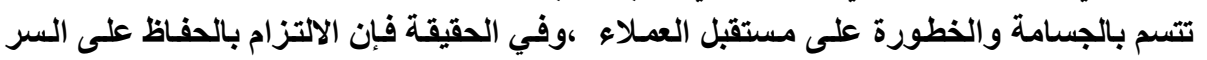

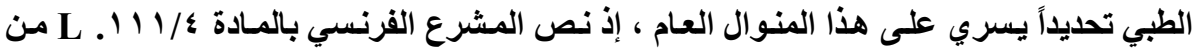

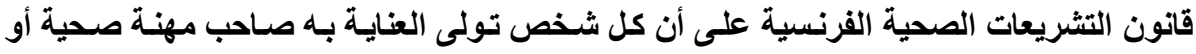

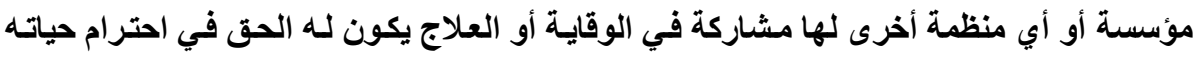

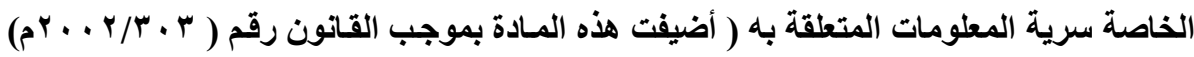

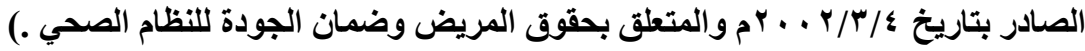

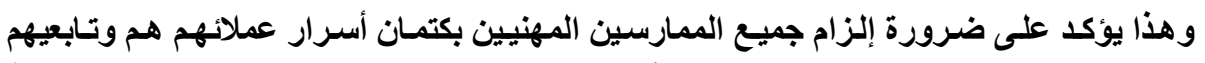

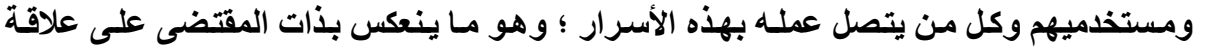

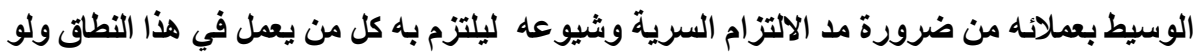
كان خارج نطاق العلاقة العقدية ذاتها.

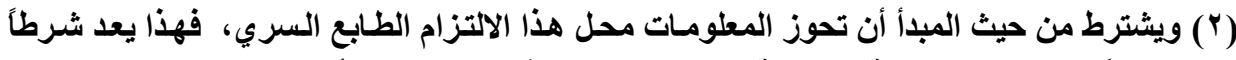

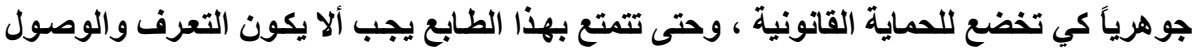

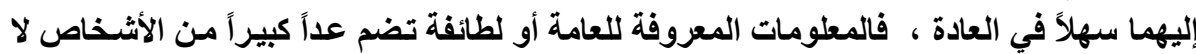

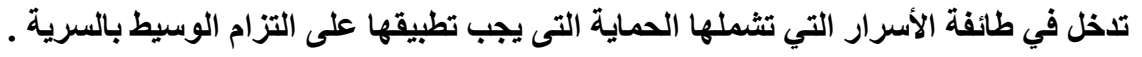


من خلالهـا بين النطاق الموضوعي لالتزام الموفق بالسر المهنـي وذلك على النحو

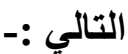

المستوى الأول :- - التزام وسيط التوفيق بإفثاء المعلومات والبيانات الأساسية لإنجاح عملية التوفيق ،بحسب أن ذلك من مقتضى الوفاء بالتزاماتهـه المباثرة كمتعاقد مهني ومحترف، فضلاً عن الالتزام بالبوح بالبيانـات والمعلومـات التي يمكن أن تشكل عملاً إجرامياً مؤثماً ، والإفضاء بها عند أداء الثهادة أما القضاء ، أو في الإبلاغ عن جريمة ، وغيرها من الحالات التي تتضمن ذات العلة والتى تضمى فى سياق الالتزام بالنظام الام والمصلحة العامة فضلاً عن الالتزام بالبوح بالبيانات والمعلومات التى يمكن

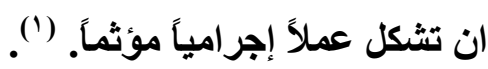

المسستوى الثـاني :- التزام وسيط التوفيق بالامتنـاع عن إفشاء المعلومـات

والبيانات التي يطلب منه راغبي الزواج كتمانها وعدم الإفصاح بها . المسستوى الثالــث :- التزام وسـيط التوفيق بإعمـال تقديره الشخصي فى الإفصاح عن المعلومـات التي تتوسط المستويين السابقين ، فيكون إذاً بالخيـار بين الإفضاء بالمعلومـات التى لـم يـتم الاتفـاق على كتمانهـا ولا تعتبر في ذات الوقت مـن المعلومات الأسساسية التى يجب عليه إفشائها ، ورقابـة هذا التقدير الشخصى للوسبط إنما يكون من قبل القضاء الأى يمحص المسوغات التى دفعت الوسيط لإفشاء السر أو

(1) أنظر في الحالات التي يجب فيها على بعض المهنيين التحلل من السر المهني وإجازة إفشائه :

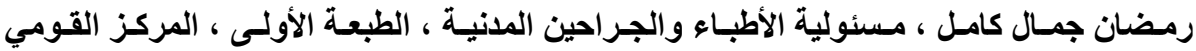

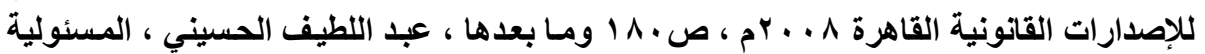

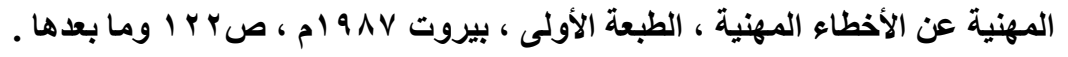


ومن زاويـة أخرى ، فإن نطـاق الالتززام بالحفـاظ على سـرية العمـلاء في عقد

الوسـاطة يمكن تحديده من الناحيـة الموضوعية بتقسيم المعلومـات محل الالتزام إلى نوعين :-

\section{أولاًا : المعلوهات والمعارف التي أسبغ عليها العميل طابع السرية.}

ويـتم ذلـك بواسطة قيـام العميل بتحديد المعلومـات والمعـارف الثخصية ذات

الطابع السري بشكل دقيق لا لبس فيه ، ثم يعرب للوسيط عن رغبتهـ الجازمسة في عدم الإفصاح عنها لأنها لا تُعد سريه بطبيعتها لكن العميل هو الذي أضفى عليها طابع السرية.

\section{ثانياً : المعلوهات والبيانات التي تتصف بالسرية بصسب طبيعتها .}

وهي تشمل كل المعلومات التي يكون من شأن ذيوعها أن تسبب ضرراً للعميل ،

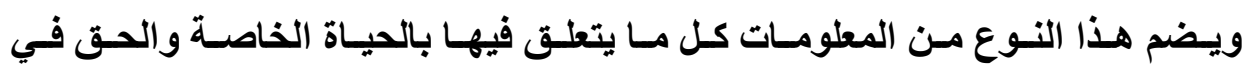
الخصوصية ؛ إذ أن شيوع هذه المعلومات قد يلحق بالعميل ضرراً ينشأ على الوسيط بمقتضاه التزامـاً بالحفـاظ على سـرية هذه المعلومـات المتوللاة عن حريـة العميل في اختيار حياتـه الخاصـة ، مثل الأسرار التجاريـة والمصرفية والوظيفية للعميل التي قـ يؤثر إفشائها على الوضع المالي والوظيفى والمصرفى له . 


\section{الإطلب الخاهس \\ الترام الوسيط بالإعلام والتبصير \\ الفرع الأول \\ هضمون الالتزام بالإعلام والتبصير}

فى الحقيقة إن الالتزامين المشار إليهما ، الإعلام والتبصير ، يرتبطان بعضهما البعض فى مجال وساطة النكاح ؛ على نحو يدفعنا لتناولهما فى مطلب واحد وباستعمال ألفاظ جامعة لهما ، حيث يتضمن التناول الموضوعى لمضمون أى من الالتزامين بيانـاً لحقيقة الالتزام الآخر ؛ لأن وفـاء الوسبط بالتزامـه بالتبصير ينطوى فى الغالب على التى تنفيذ التزامه بالإعلام والعكس صحيح ، فكلاهما يتعلق بواجب الوسيط فى تزويد العميل

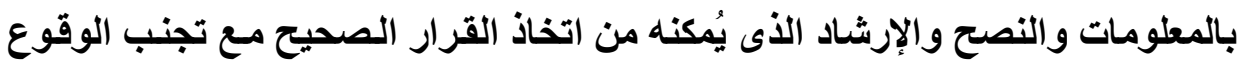

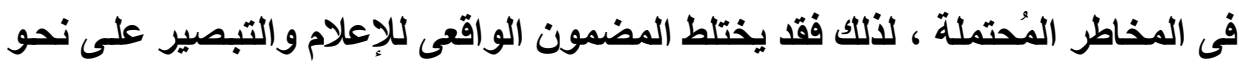
يصعب معه الفصل بينهما رغم تباين المعنى اللغوى والمفهوم القانونى لكل منهما. ويُعد الالتزام بالإعلام والتبصير من أهم الالتزامات التي تقع على عاتق وسيط

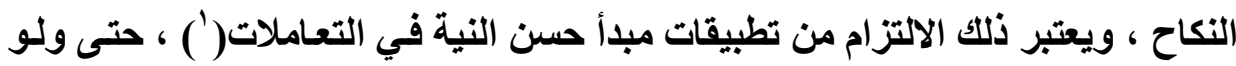

(1) وتبرز أهمية الالتزامـا بالتبصير في المجال الطبي تحديداً ، حيث يلتزم الطبيب بصفة أساسية

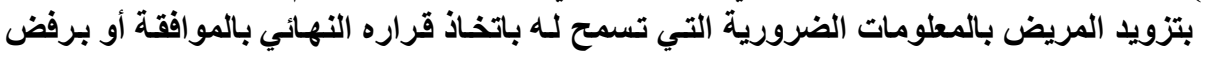

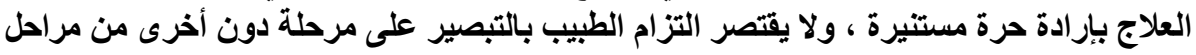

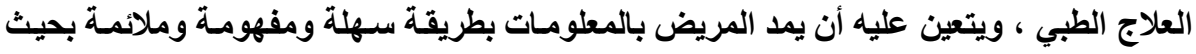

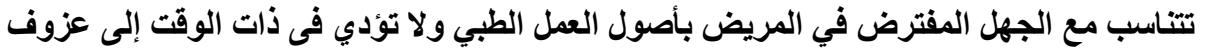
المريض عن اتخاذ القرار المناسب لهئ.

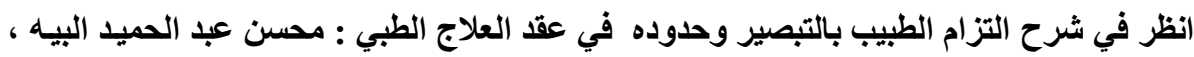

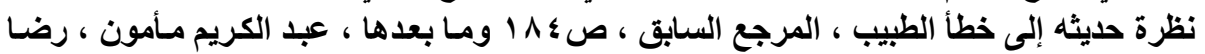

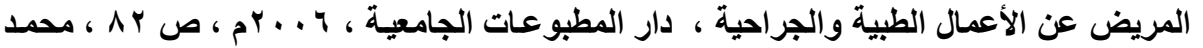

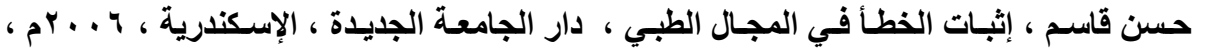

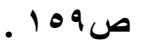




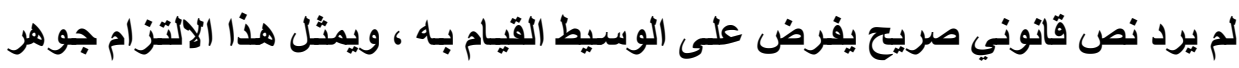

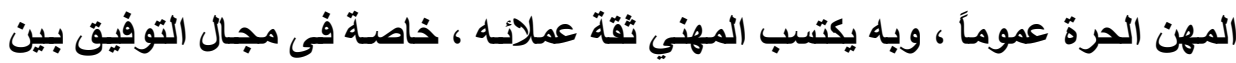
الراغبين في الزواج ، إذ يمثل الالتزام بـالإعلام والتبصير أهم وأكثر الالتزامـات تأتئيراً

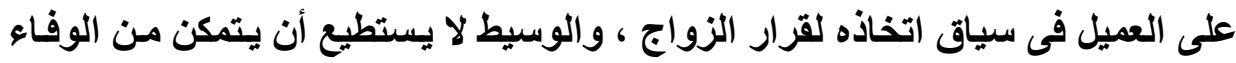

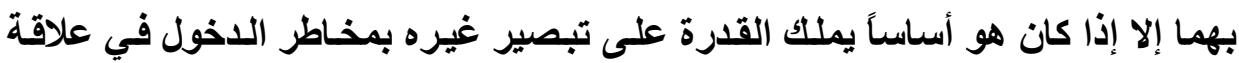

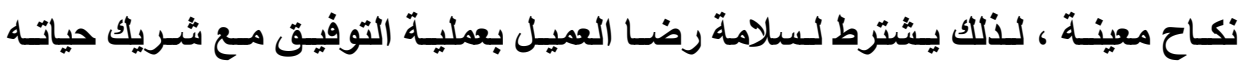
المتوقع، أن يقوم الوسيط بتبصيره بالمخاطر المتوقعة التي يمكن أن يتعرض لها لهاب ، لأن

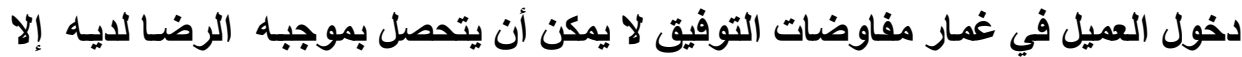

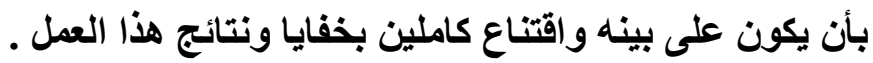
ويقصد بتبصير العميل وإعلامه ، التزام الوسيط بتزويده بالمعلومات الضرورية التي تسمح له باتخاذ قراره النهائي بالموافقة على الاخول في نطاق المفاوضات الجادة و إصـدار القبـول المبلئي بالارتبـاط الششرعي بـالطرف المقابـل رجـلاً كـان أم امـرأة ، فواجبات الوسيط لا تقتصر عند إحداث صلة من التعارف بين العميل وشريك حياة محتمل يتمتع بالصفات المرغوبـة ، بل تتسع مسئوليته لتشتتمل على تعهده بإحاطة العيل وتوجيه بصره إلى ملابسات العلاقة التي يوشك أن يتفاوض بشأنها ، وأن يبرز

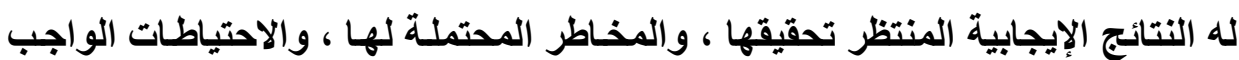

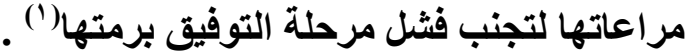

(1) ويتثابه التزام الوسيط بالإعلام والتبصير ، مع التزام البائع تجاه المستهلك حيث يلتزم الأول تجاه

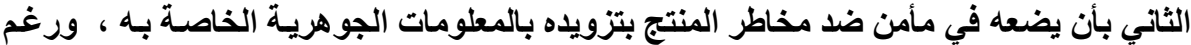

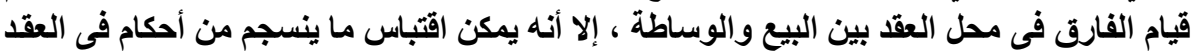
الأول مع ما يمكن تطبيقة فى العقد الثانى .

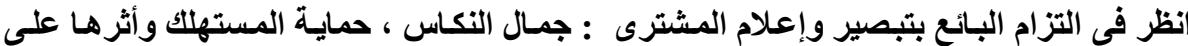
النظرية العامـة في العقد في القانون المدني الكويتي ، مجلة الحقوق ، الإسكندرية ، صه ؛ ، ؛ 
وبتطبيق مفهوم الالتزام بالتبصير والإعلام في نطاق الوساطة التوفيقية للنكاح ، فإنـه ينبغي حتى يتخلص الوسيط من المسئولية عن أداء هذا الالتزام ، أن يبصر العميل بالسلبيات التي تحيط بمواصفات الطرف الآخر ، وما هي انعكاسـاتها على نجاح الزواج المتوقع من عدمه ، وذلك بإحاطة العميل بتقديرات الوسيط الثخصية والمهنية لشريك الحيـاة المحتمـل ، مـن حيث ملائمـة سـنه وميولـه وأحوالـه المزاجية وقدراتـه المالية ووظيفته المهنية لظروف وأحوال العميل ، والتتبيه على الأخير بما يتوجب عليه تداركه والاحتياط لـه حتى تنجح المفاوضـات في إدراك القبول والتوفيق بينهما ، وأن يحـث العميل على اتخـاذ القـرارات وأن يتبنـي مواقـف معيــهـ ؛ حتى يتكلل مجهـود المُفاوض الوسيط بالنجاح ، بواسطة إحداث حالة من التجانس والتوافق بين طرفي النكاح الذي يبتغي الجميع إتمامسه ، وفى ظلال إحاطة شـاملة للعميل بالمزايـا والمثالب والمخاطر التى تتربص بعملية الزواج التى يقدم عليها.

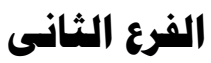

\section{طبيعة ونطاق الالترزام بالإعلام والتبصيز}

يُعتبر تنفيذ الالتزام بالإعلام والتبصير تاماً عندما يقوم الوسبط المدين بإحاطة

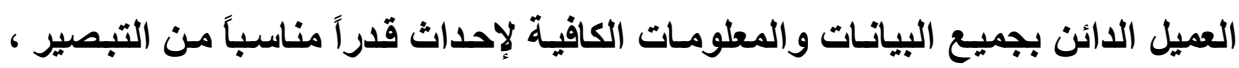
اللَى يكفى للتنبيه بمخاطر ومحاسن الدخول مـع شخص مـا في علاقة زواج شرعية قوامها المودة والرحمة ، لذلك يقوم الالتزام بالتبصير من الناحية الزمنية على عاتق الوسيط في جميع مراحل التوفيق ، فهو يلازمه منذ إيجاد الشريك الملائم للحياة ، وفيما 
يعقب ذللك ، وفي مختلف المراحل الزمنية التي تمر بها عملية المفاوضات التوفيقية بين الطرفين(') ؛ ويرجع ذلك لأن اتخاذ العميل لقرار الارتبـاط بشريك حياة مثالي ، يشكل عبئًا ذهنياً لا يستطيع العميل تحمله بمفرده ، بسبب ارتباطه بقرار مصيري في حياة الفرد ، وغالباً ما يثير هذا الأمر تردد كبير لاى من يقبلون على الزواج ، ولا شك فبان إبرام عقد الوساطة يلقى على الوسيط دوراً جوهرياً في اتخاذ العميل لذلك القرار الهام ، لألك فلا ينحصر التزامه بالتبصير على مرحلة دون الأخرى ، بل هو التزام يثقل كاهل الوسيط منــ مبدأ التعارف بين الطرفين وحتى انقضاء المرحلة الأخيرة للمفاوضـات برمتها ، وسواء مُنيت بالفثل أو أفضت إلى إبرام عقد الزواج المرغوب.

ومن حيث النطاق الموضوعي للتبصير ، فلا ينبغي الإفراط فيه بإلزام الوسبط

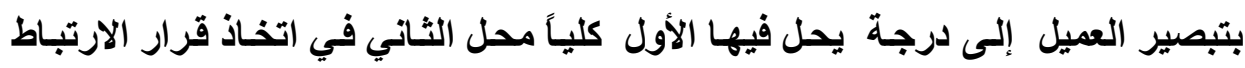

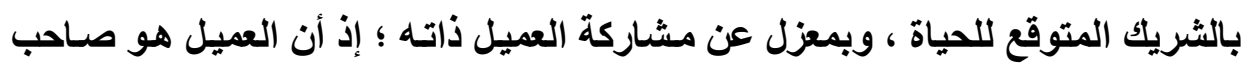

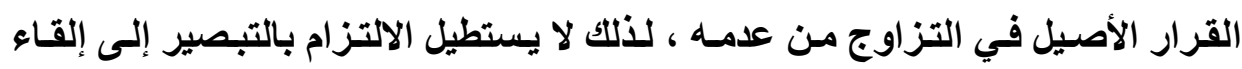

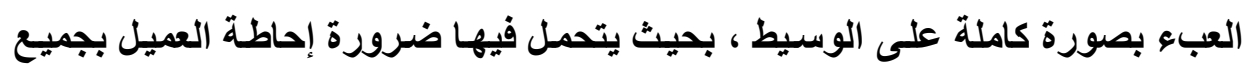
التقديرات الثخصية والتوقعات التفضيلية لمخـاطر المفاوضـات أو نتـائج الارتباطـات الثرعية بشريك الحياة ؛ لأنه لا يستساغ تحميل الوسيط ما لا يتحمله العميل ذاته بشأن

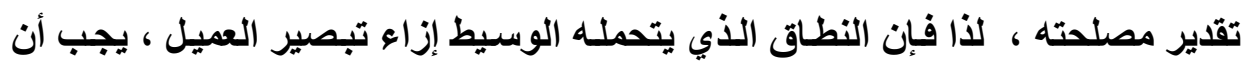
يتوقف عند حدود إحاطته بالمخاطر والتقديرات المتوقعة من خلال تزويده بالمعلومـات الاقيقة والجوهرية وتلقينه النصائح والإرشادات الطبيعية ، ولا ينصرف التبصير بحسال

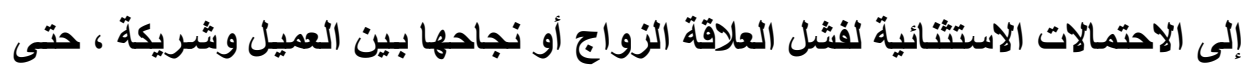
لا يؤدي هذا الإفصاح التفصيلي ذو الأبعاد المتغيرة والاحتمـالات القصوى إلى إعاقـة لإنة 
مجهودات الوسيط ذاته ، فضلًا عن أن إعلام العميل والتنبيه عليه بكل صنوف المخاطر

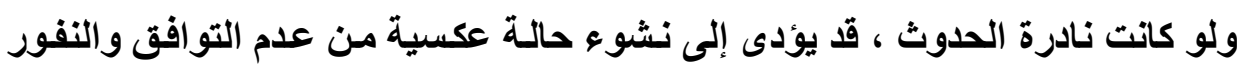
بين العميل وشريكه المتوقع في الحياة ، فضلاً عن أن هذا الإفراط في التبصير قد يولـ يولد الفزع لاى العميل ويدفعه لرفض الاخول في مفاوضات التعاقد وقبول الآخر (') . ولا شكك فإن الوسيط يملك السلطة التقديرية لتحديد نطاق المعلومـات الجوهريـة والتقديرات الثخصية التي تندرج في سياق التبصير المُلزم ، وتلك التي لا يلزّم إحاطة العميل بها ، وتخضع هذه السلطة لرقابة المحكمة التى تقدر مدى صحة المسوغات التي اعتد بهـا الوسـيط في هـا الشأن ، في ضـوء دراسـة المعطيـات المتـوفرة وصـفات ومعلومات الطرفين الراغبين في الزواج ، بحيث يضحى الوسبط مقصراً في التزامهـ

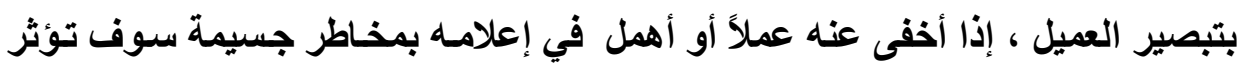

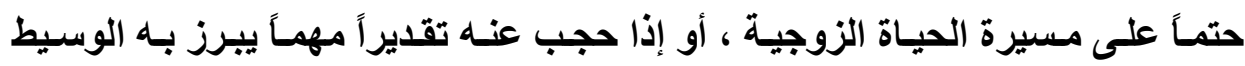

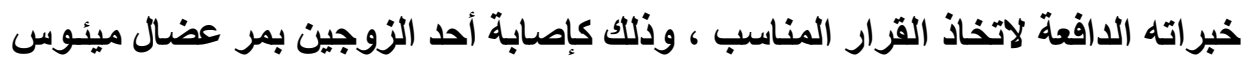

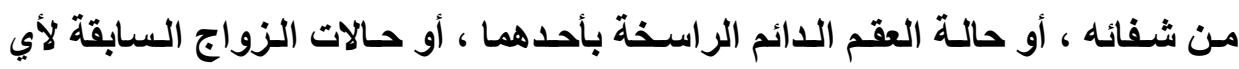

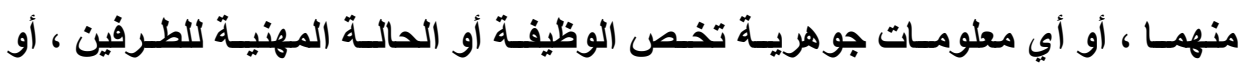
انتكاس الأحسوال المـاديـة لأي منهمــا ، وغيرهـا مـن المعلومــات الجوهريـة التـي تشكل مخاطر جسيمة ، بحيث لو علم بها العميل ، أو لو قدم له الوسيط خبراته المهنية بشأنها

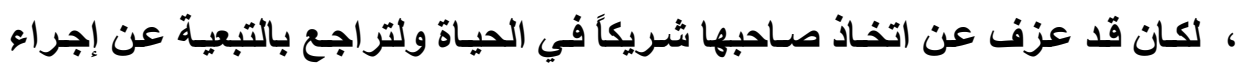
المفاوضات التوفيقية من خلال الوسيط الذي تعاقد معه ـ

( ) حيث يذهب الفقه وبصفه عامة إلى أن المدين بالالتزام بالتبصير لا يُطالب بإعلام دائنه بكل صغيره وكبيرة من المعلومات التي يحوزها لكنه يلتزم بتقليم المعلومات ذات الطبئ الطبيعة الجوهرية فحسب.

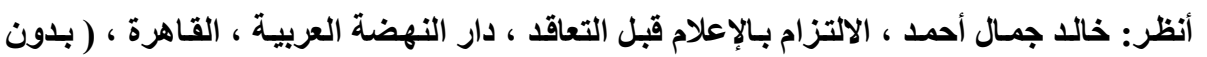

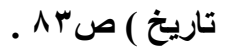


وتختلف طبيعة الالتزام بالتبصير عن الالتزام بإيجاد شـص يتمتع بالصفات

المطلوبة ، فرغم أن محل نوعى الالتزام يتمثل فى معلومـات وصفات العمـلاء الراغبين

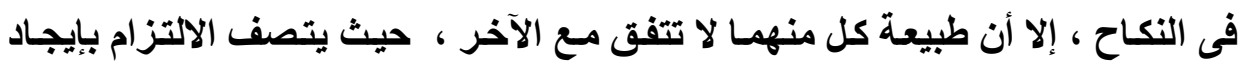
المواصفات بكونه من الالتزامات المحددة بنتيجة ، ويصبح الوسيط المدين بتنفيذها

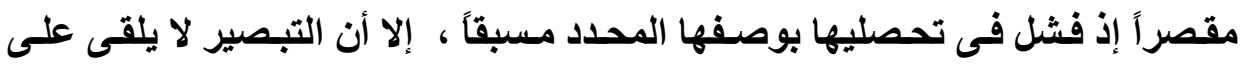

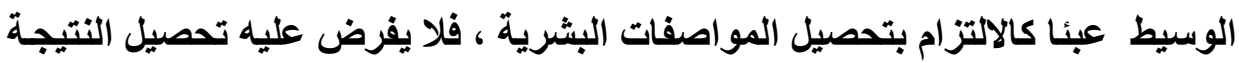

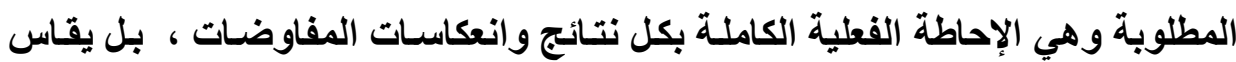
مسلكه الذي يحدد مدى تقصيره بمعيار بذل العنايـة الواجبة في التبصير ، من خلال

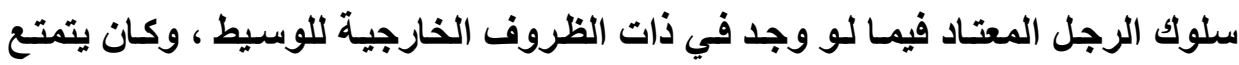
بذات القدرة والخبرات المهنية لـه ، وفي ضوه مـا وصل إليسه من معلومـات وبيانـات

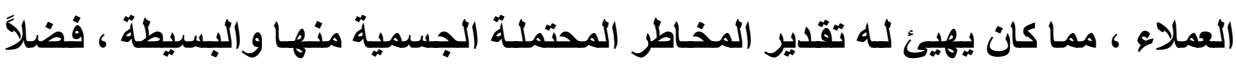
عن دراسة مسلكه في استعمال سلطته التقديرية في إحاطة العميل بمخـاطر المفاوضـات الجسيمة أو الامتناع عن إعلامه بالنوع البسيط منها (') .

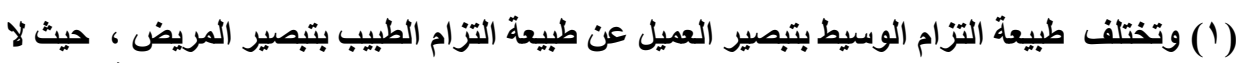

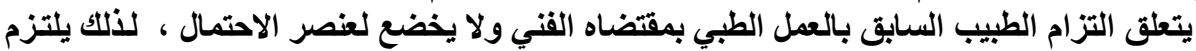

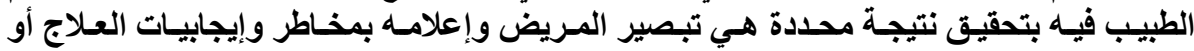

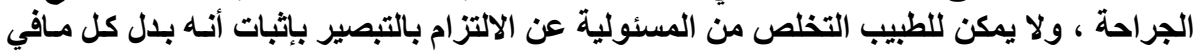

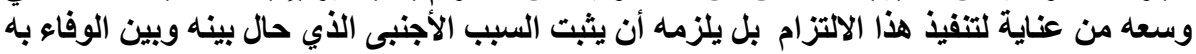

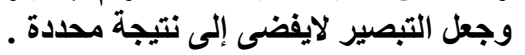

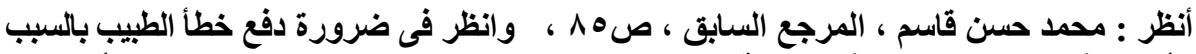

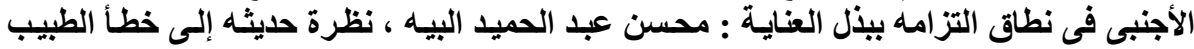

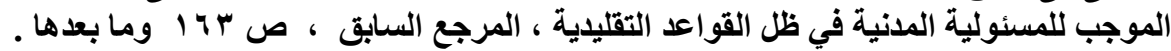

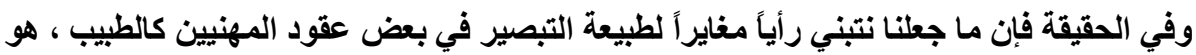

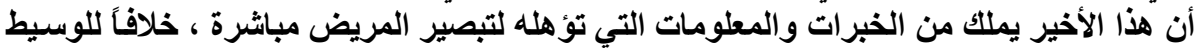

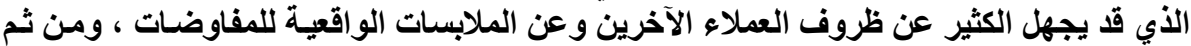

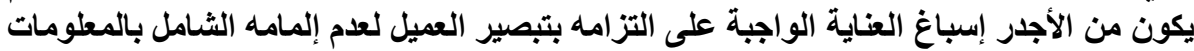

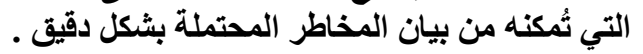


ويناء عليه ، فبإذا كان التبصير يتعلق بمعلومـات خطيرة ، فبان التزام الوسيط بتبصير العميل يجب أن يتخذ صورة التحذير والتتبيه للاحتياط منها وكيفية تدارك آثار هذه الخطورة باتخاذ القرار المناسب ، كما ينبغي أن يكون هذا التحذير كافياً لشد انتباه العميل إلى كافة المخاطر التي يمكن أن يتعرض لها أثناء فترة المفاوضات التوفيقية أو فيما بعد انعقاد الزواج وإتمامه ، وأن يبين لـه الوسـائل اللازمـة لتجنب النتائج السلبية للمعلومة ، ومن ثم فلا يكفي لتحقق التبصير التحذير المختصر الذي قد يلفت انتباه العميل لبعض مـن المخـاطر دون البعض الآخر ، كمـا يتعين أن يتسم التحذير بالدقة والوضوح اللازمين من تمكين العميل من اتخـاذ القرار بالموافقة أو بـالرفض ، خاصـة إذا كانت هناك فرصة من المفاضلة بين أكثر من شريك حياة مطروح على العميل ، فبإن إحاطته بالمخـاطر التـي ترتبط بكل شـريك على حده ، وتبـيره بمحاسـن ومسـاوئ الارتباط بكل منهم ، ويعطي العميل الراغب في الزواج ، القدرة على اختيار الشريك الأكثر ملائمة لظروفه المادية والاجتماعية .

بيــ أن التزام الوسـيط بتزويـــ العميل بالمعلومــات والبيانـات التـي تمكنـه مـن التبصير بالثريك المتوقع للزواج ، لا يقتصر على تلك التي تتعلق بذاتية العميل فحسب

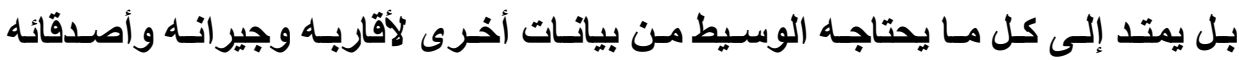
وأزواجه السابقين ، شريطة أن يكون ذلك أمراً ميسراً للدى الوسيط ، وذلك لأن عدم إحاطة العميل بهذه المعلومات الإضافية ، قد تعرقل عملية اتخاذ القرار النهائي بـالزواج وحصول الموافقة المبئية بمواصفات الطرف الآخر .

ومن حيث طبيعة المعلومات والمخاطر ذاتها ، فإنـه من غير المتصور ، إلزام الوسيط بتقلم المعلومات وتبصير العميل بالمخاطر ، ما لم يكن هو على علم بها وبمدى أهميتها للعميل ، كمـا لا يفترض في الوسيط العلم والإحاطة بكل ظروف ومعلومـات 
الأثخاص الأين يستجلبهم للعميل بغرض أن يوفق بينهم ، إلا أنسه ينبغي التفرقة بين نـوعين مـن المعلومـات في هـا الشأن ، فهنـاك مـن المعلومـات التي تتصف بكونهـا أساسية في العملاء ولا يتصور جهل الوسيط بها ؛ إذ يكاد يكون العلم بها مفترضـاً في جانبه(') ، وذلك مثل سن العميل وحالته الاجتماعية ووظيفته التي يتقلاها وغيرهـا من الصفات الأم التي قلما يجهلها الوسطاء أو يخفيها العملاء ، فهذا النوع من المعلومـات يقوم بشأنها قرينة العلم بحق الوسيط ، إلا أن هناك نوع آخر من المعلومـات قد يجهلها الوسيط أو يعجز عن إدراكها ، أو يُهمل التوصل إليهـا لاعتقـاده بعدم أهميتهـا لإتمـام الارتباط ، وذلك مثل العلم بالاخل المادي الحقيقي للعميل ، أو بميوله الأتيـة وهواياته الشخصية ، أو حالته العصبية ومزاجه النفسي وطبيعة انفعالاتهه ، والمستوى المـادي والاجتماعي لأسرته و أقاربه ، وغيرهـا من المعلومـات غير الجوهريـة ، التى لا يسأل الوسيط عن الالتزام بالتبصير بشأنها ، إلا إذا كان العميل قد اشترط إدراك خفاياهـا عند إبرام العقد مع الوسيط ، أو كاتت هذه المعلومات مهمة بمكان وفقاً لملابسات التوفيق

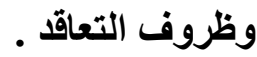

كما لا ينشأ الالتزام بـالإعلام والتبصير على عاتق الوسيط ، إذا كـان الاستعلام عنها بالنسبة إليه مستحيلاً ، فيجب لذلك أن يكون الوسيط فضولياً بالبحث والتحري

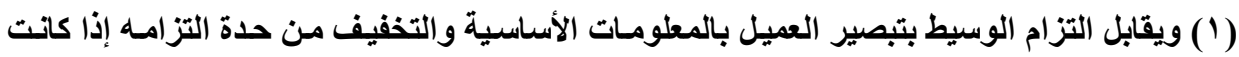

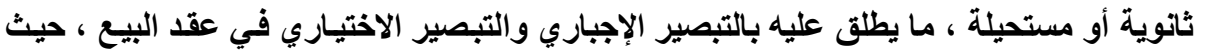

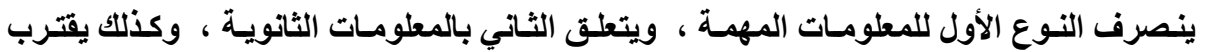

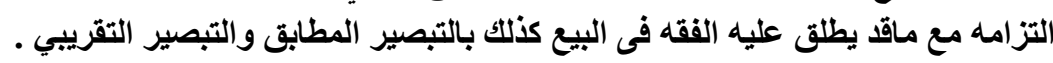

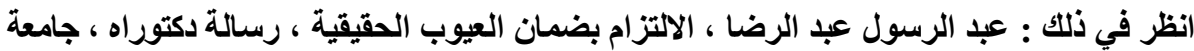

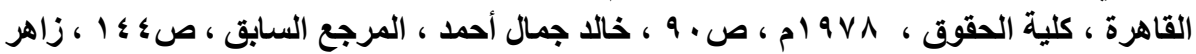

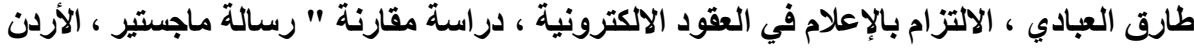

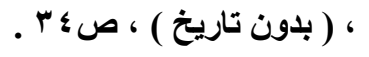


بنفسه أو من خلال تابعيه عن البيانـات والمعلومـات الخاصـة بشريك الحيـاة المطلوب ، إلا أن قيـام مسئوليته عن الوفـاء بالتبصير في هذا الصدد تضحى رهينة بـأن يكون الحصول على المعلومة ممكناً ـ كما يستطيع الوسيط أن يدفع عن عاتقهه عبء الالتزام بالتبصير ، إذا كان العميل على علم بهذه المطلومات ، أو كان باستطاعته الوصول إليها بمجهوده الذاتي ، ققد لا يكون حصول الوسيط على المعلومات والصفات مستحيلاً ، إذا ما بذل بثأنها جهداً مناسباً بالتحري والبحث والتدقيق ، إلا أن عدم اكتراثهه بالحصول

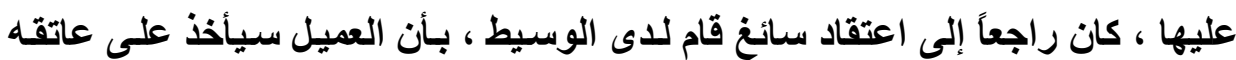
المبـادرة بالاسـتعلام عن هذه الصفات أو تلكـ البيانـات التـي أغفـل الوسـيط إدراكهـا بمجهوده الفردي ، أو تبين للوسيط بدليل جدي أن المعلومات قد دخلت فعلاً في نطاق علم وإحاطة العميل ، عندئذٍ يقتصر دور الوسيط على تقديم النصح والمشورة للعميل بشأن الأثر المترتب على هذه المعلومات ، والنتائج الخطيرة التي تثكل انعكاساً محتملًا لها على علاقة الزواج المتوقع ابرمها ـ

وأخيراً فإنـهـ يمكن للوسـيط أن يحقـق هـذا العبع التعاقـدي وبوصـفه التزامـاً جوهرياً بالغ الأهمية ، بواسطة استخدام وسائل معينة ، من بينها ما يكون شفهياً ، وقد يتم التبصير كتابيـاً ، ويعتبر التبصير الشفهى الوسـيلة الأكثر استعمالاً بين الوسيط وعملائهـ ، وذلك لمـا تتسم بـه من بساطتها وسـهولة تداولها ، فضلاً عن قدرتها في الإقناع وبيان للمخاطر على نحو يسير ، فعن طريق الحوار الشفهي الذي يجري ببين العميل والوسيط ، يتمكن الأخير من تبصير الأول بواسطة إمداده بالمعلومـات الفوريـة والتببيه عليه بتوقعاته وتقديراته عن شريك حياته الذي يؤمل الارتباط به ـ . 


\section{المطاب السادس}

\section{الالترام بعدم هخالفة أحكام الشريعة الإسلاهية}

كما سبق البيان فإن إبرام عقد الزواج ليس من الالتزامات التي تقع على عاتق الوسيط بمقتضى عقد الوساطة الذي يبرمه على العميل ، وأن مجمل التزاماته التعاقديـة تنشأ ويتم تتفيذها في مرحلة سابقة على إبرام عقد الزواج وتوثيقهـه بمعرفة المـأذون الثرعى ، فالعلاقة التعاقية التي ينبري مضمونها حول الوساطة التوفيقية بين راغبي الزواج ، تختلف تماماً عن تلك المتمثلة في رابطة الزواج بين العميل وشريك حياته المتوقع ، فإذا كاتت العلاقة الأولى تمهد لإبرام الثانية ، و إذا كانت الأخيرة تعبر عن نجاح الأولى في إحداث التوافق الأي يفضى للزواج ، لكن هذا الارتباط لا يعنى اتحاد العقدين ، ولا يدفع بالوسيط لأن يكون طرفاً في رابطة الزواج ، فهو بالنسبة لهذه

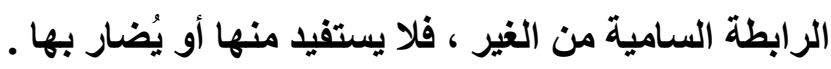
وعلى الرغم مـن المُسلمة المتقدمة ، فـإن الوسيط يقع على عـاتق قائمسة من الالتزامات تتعلق بضرورة تحرى الأركان والثروط التى يلزم توافرهـا فى عقد الزواج وشروط صحته (') ، ويجمع بين عناصر هذه الالتزامات مبدأ عام ، يمكن صياغته في

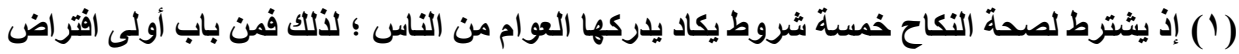

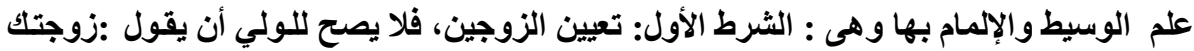

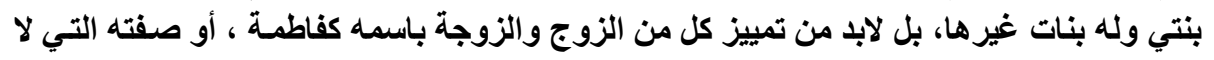

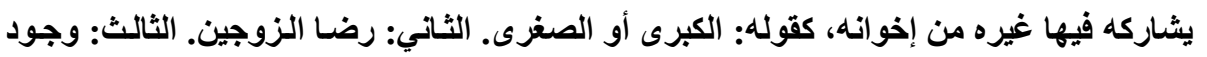

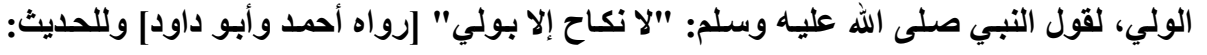

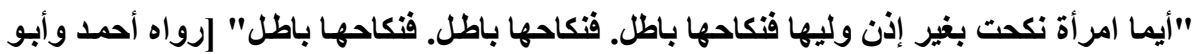

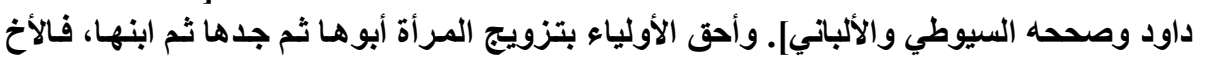

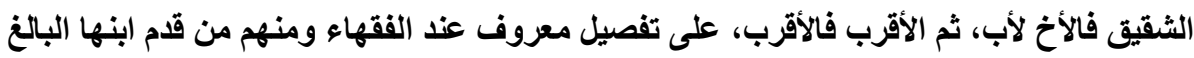

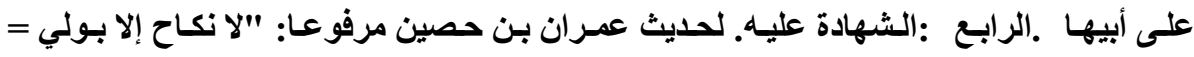


مسمى الالتزام بعدم مخالفة الوسيط للأحكام الشرعية التي تنظم عقد الزواج وتحدد فيها أركان الانعقاد وشروط الصحة ، فكل ما يؤدي إلى بطلان هذا العقد أو انحلالهه بفقدانهـ أحل شروط سلامته وصحته وجوده ، يمتنع على الوسيط إتيانه أو المشاركة فيه . وكنتيجة مباشرة لألك ، يلتزم الوسيط بعد ممارسة البحث والتوفيق بين عملائسه الذي هم تحت السن القانوني للزواج ، حيث إنتظم قانون الأحوال الثخصية تحديداً لسن الززواج بالنسبة إلـى الرجل والمـرأة ، وهـا التحديــ يتسم بالتحكميـه التـي لا يجـوز مخالفتها وإبرام عقد الزواج بدون توافرهـا ، لذلكك يمتنع على الوسيط أن يبرم عقد الوساطة مع أشخاص أقل من السن المقررة للزواج ، أو أن يتوسط مبرمـاً عقده مـع الولى الشرعى للمرأة ما دام أنها لم تبلغ هذا السن كذلك.

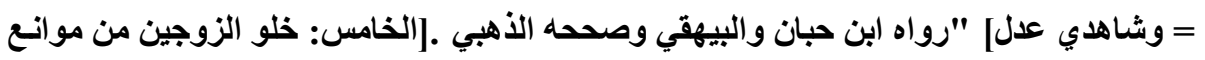

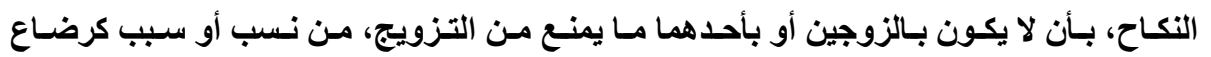

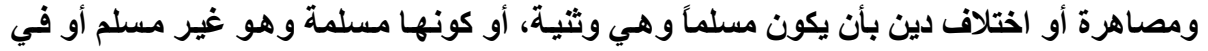

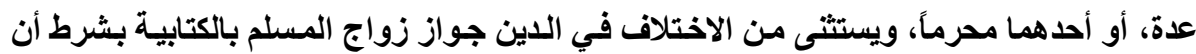

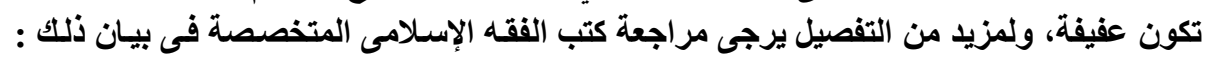

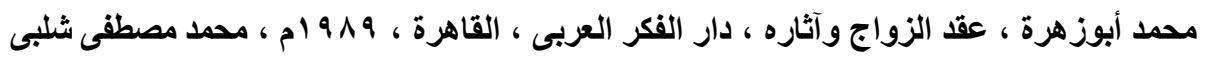

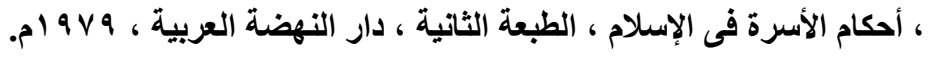




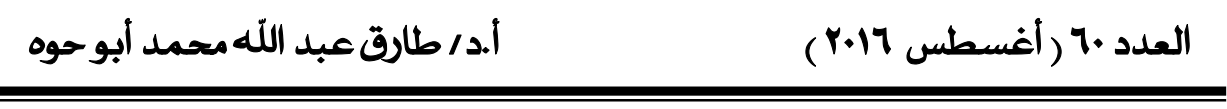

\section{المبحث الثانى}

\section{التزامات العميل العقدية}

من خلال استجلاء طبيعة عقد وسـاطة النكـاح ومـا يمكن تصوره بشأن مـا قد

يلقيه من التزامـات على عاتق العميل ، وفى ضوء مـا سبقى تبيانـه من شروح تناولت التزامات الوسيط العقدية تجاه عملائه ، فإننا يمكن إيجاز التزامـات الأخير فى المطالب

$$
\text { المطلب الأول:- الالتزام بالسرية والإفصاح. }
$$

\section{المطلب الأول}

\section{الالترام بالسرية والإنصاح}

ونتولى شرح هذا المطلب من خلال الفرعين الآتيين:-

الفرع الأول : مضمون وحدود التزام العميل بالإفصاح.

الفرع الثانى : مضمون وحدود التزام العميل بالسرية . . 


\section{الفرع الأول}

\section{هضمون وحدود التزام العميل بالإنصاح}

لا يتسنى للوسيط أن يمسارس مهـام عمله على وجـه الإطـلاق ، إلا إذا حساز

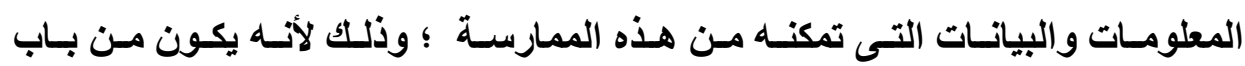
المستحيل أن يوفى الوسيط بالتزاماتهه العقديـة المتعددة إلا بعدما يتزود مـن عملائسه

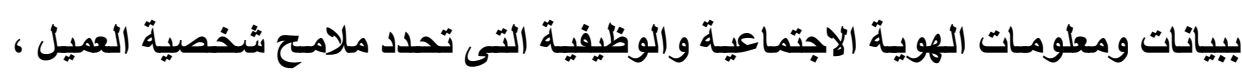

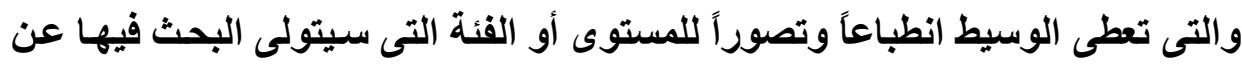

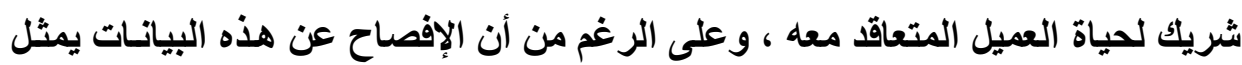

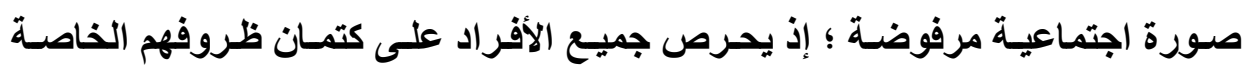

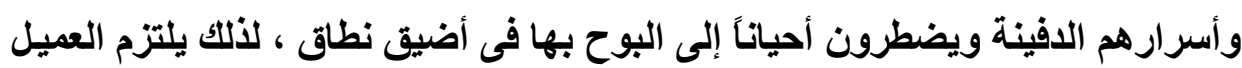

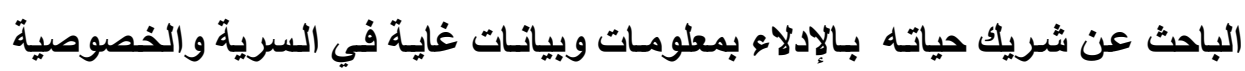

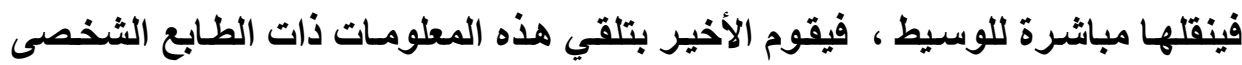

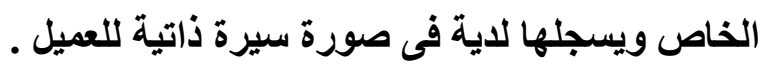

على إثر ذلك يتولى الوسيط تنفيذ جميع الالتزامات التى يمخضها العقد في ذمته

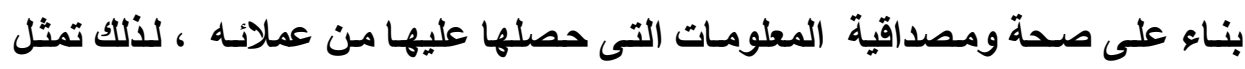

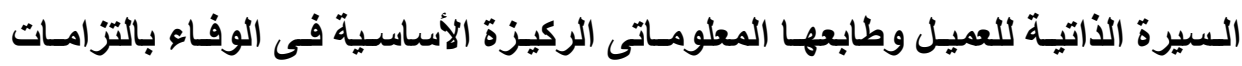

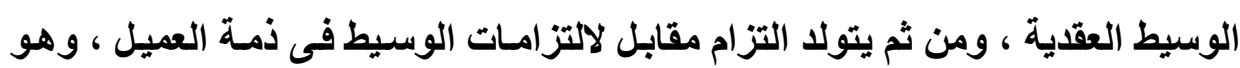

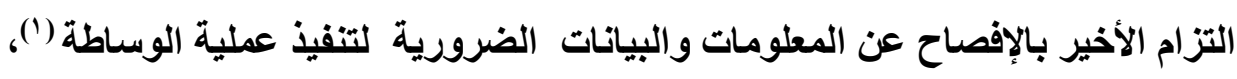

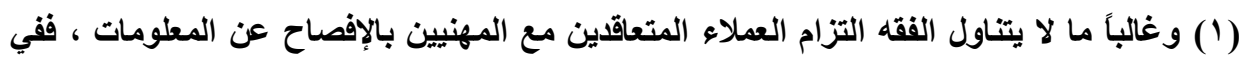

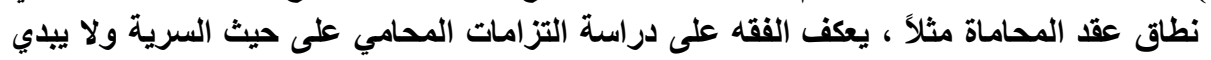

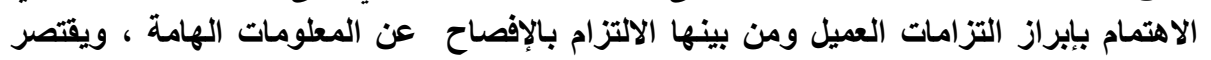

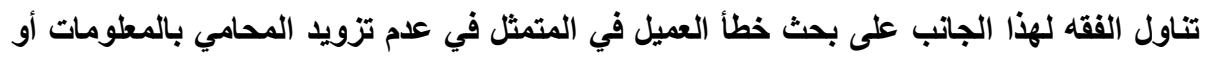

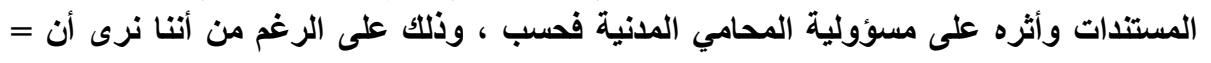


ويستطيع الوسيط أن يتمكك بالدفع بعدم تنفيذ التزاماته العقدية التى يكون محلها هذه

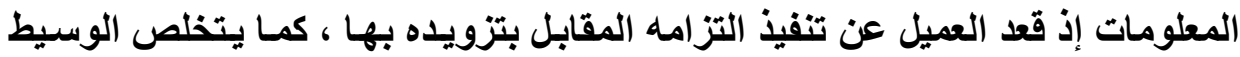

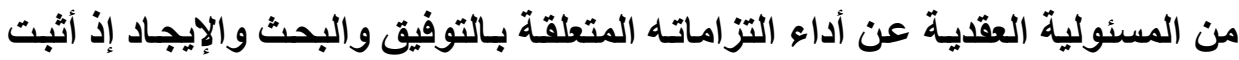
إخلال العميل بالتز امه بالإفصاح عن البيانات التى تمكنه من ذلك.

ويبدو التعارض قائماً ما بين مصالح العميل والوسيط فى خصوص الحدود التى يجب على العميل الإفصاح بمعلوماته فيها ؛ حيث يكون مسانح المعلومـات حريصاً كل

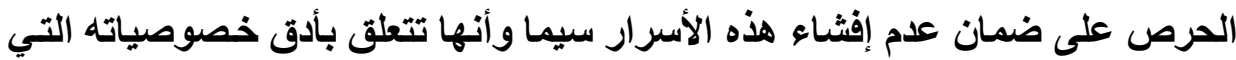
لا يرغب في أن يطلع عليها أحداً إلا للضرورة القصوى ، وذلكت لأنها فى الغالب تكون

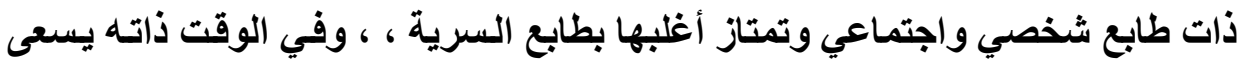

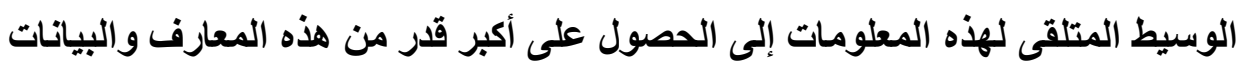

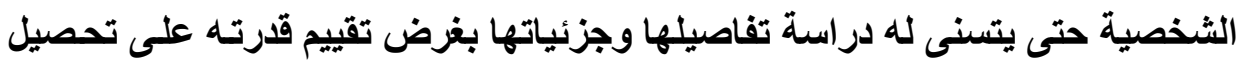
فرصة الارتباط بزوج يتمتع بالصفات المطلوبة (1)

العان = التزام بالإفصاح يُعد من الأعباء التعاقية الرئيسية التي يتعين على العملاء الإفصاح بها لأرباب

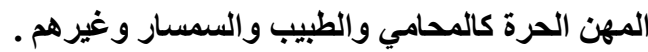
أنظر في طريقة تناول الفقه لحدود الالتزام بالسرية فى نطاق عقد المحاماة : :- محمد عبدالله حمود

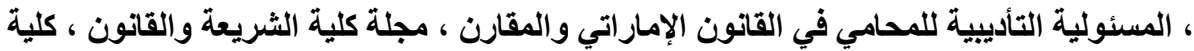

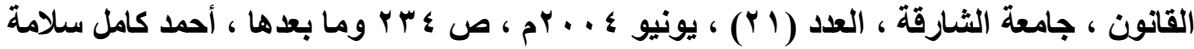

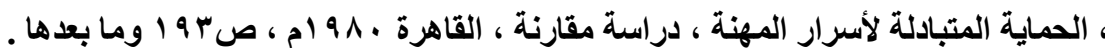

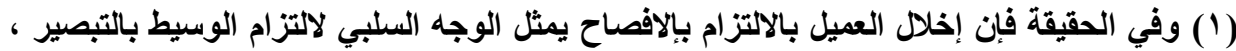

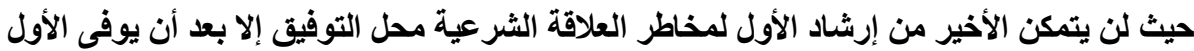

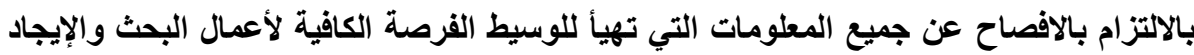

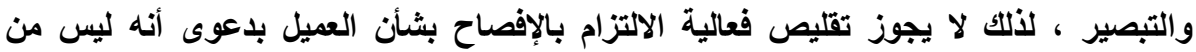

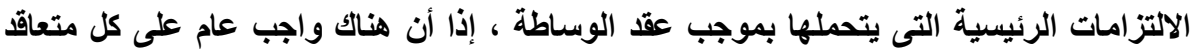

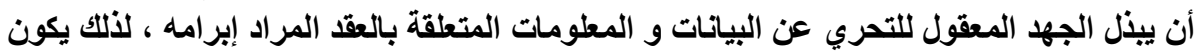

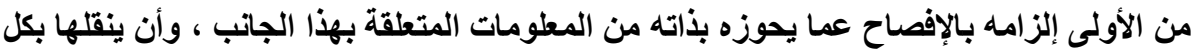
مصداقية ودقة للمتعاق الآخر. 
لذلك نرى أن نطاق التزام العميل بالإفصاح عن معلوماته يتقيد بألا تكون هذه

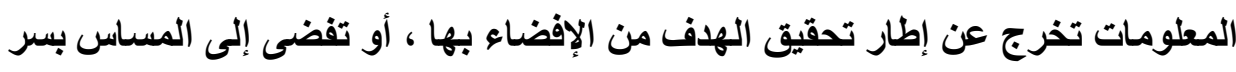

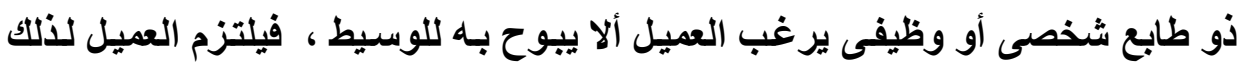

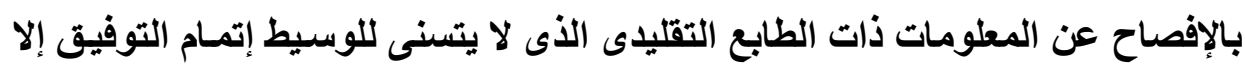

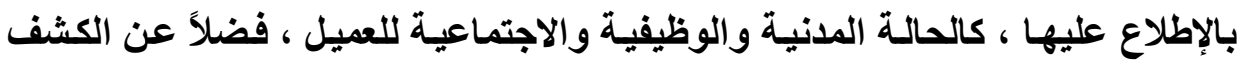

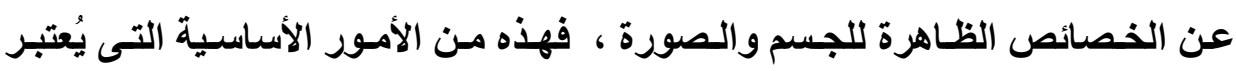

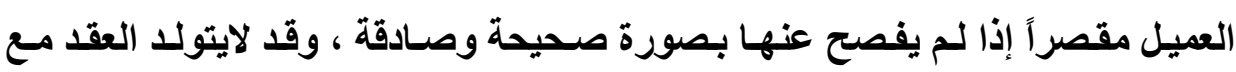

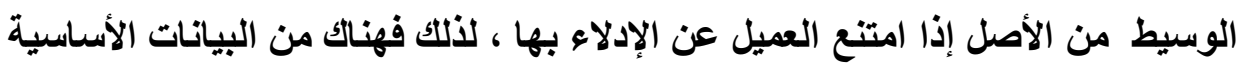

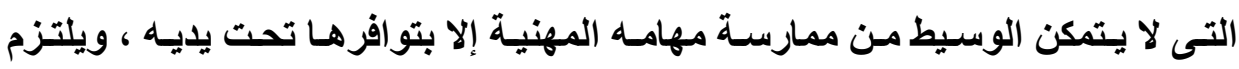

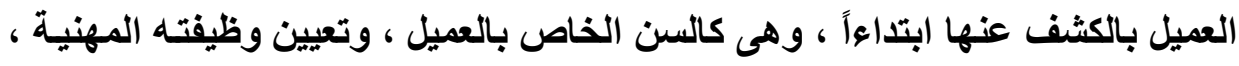
وتدديد حالته الاجتماعية ، وتمكين الوسيط من إبصار صورته الجسمانية . بيد أنه ليس للوسيط أن يتجاوز نطاق هذا النوع التقليدى من البيانات الخاصة

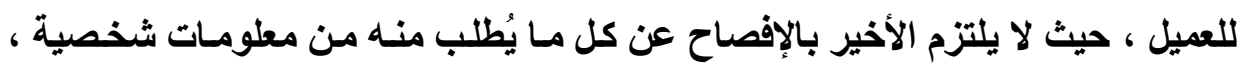

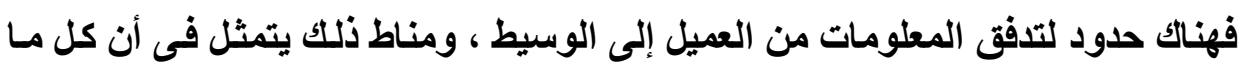

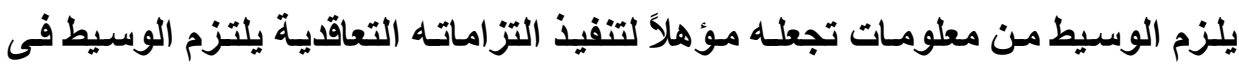

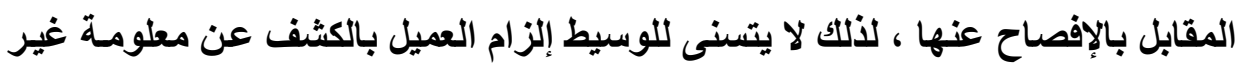

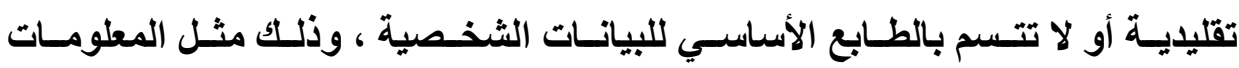

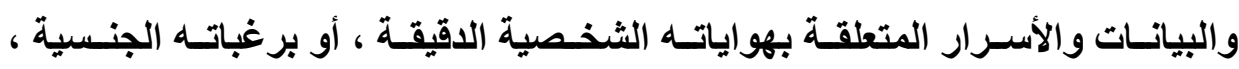

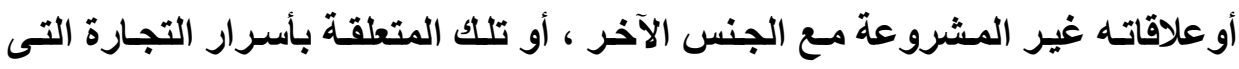

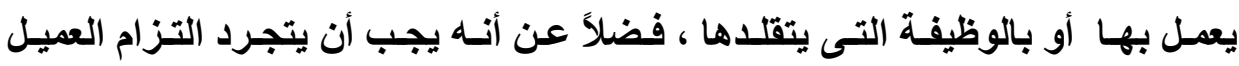

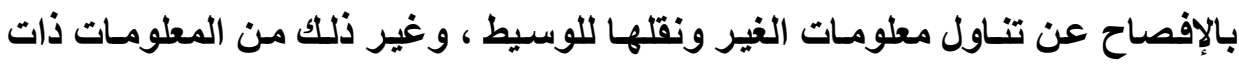

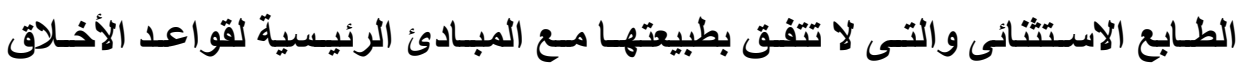
ومقتضيات الأمانة وحفظ الأسرار. 


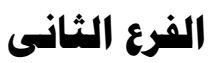

\section{هضمون وحدود الترام العميل بالسرية}

لا شك فإن حظر تداول الأسرار التي تحصل عليها العميل من قبل الوسبطوهمـا

بصدد إنجاز المصلحة المشتركة لهمـا مـع الطرف الآخر ، لهى مـن الالتزامـات العقديـة التى يتحمل عبئها العميل دون شكك ، فكل ما يقع فى نطاق علمه من معلومسات وبيانـات تخص الطرف الآخر يكون مشمولاً بالتزامه بالحفاظ عليه وعدم تداوله مع الغير ؛ وذلك

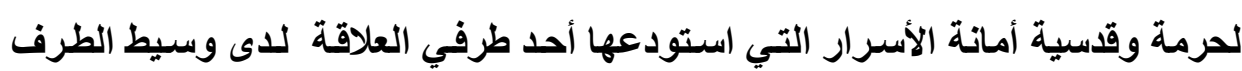
الآخر ، حيث يتجسد فى مسلك العميل الذى يفصح عن معلومـات الطرف الآخر ركن

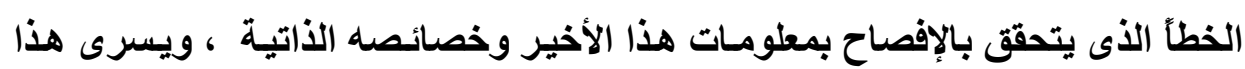

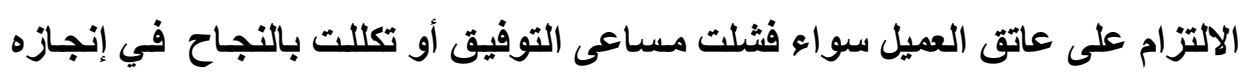

فيما بينهما. (1)

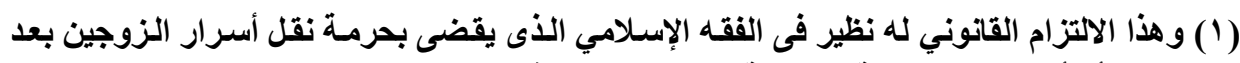

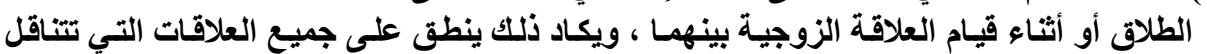

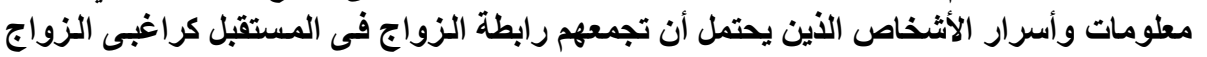

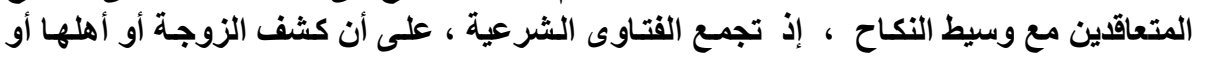

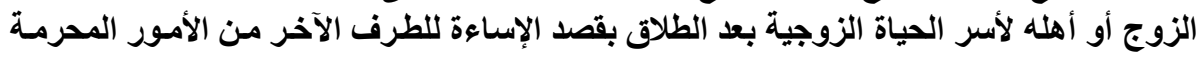

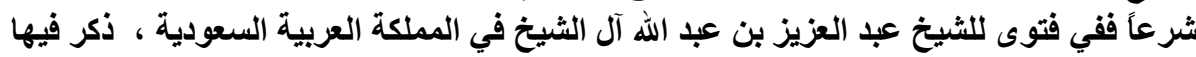

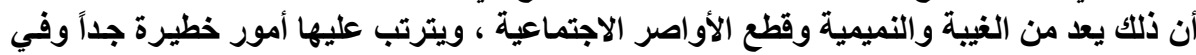

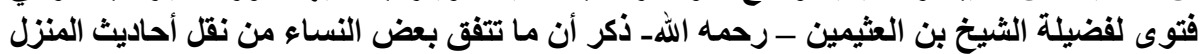

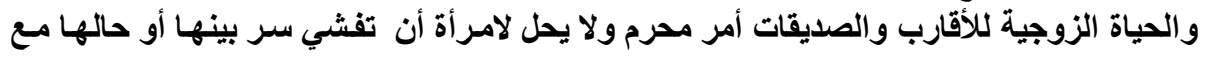

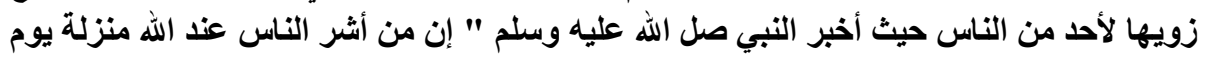

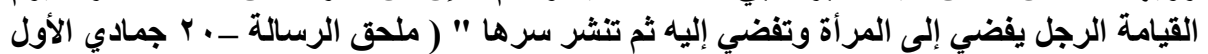

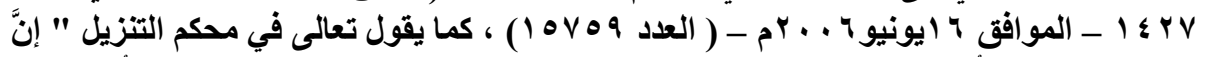

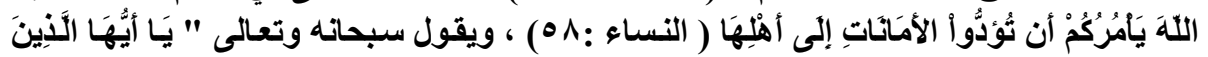

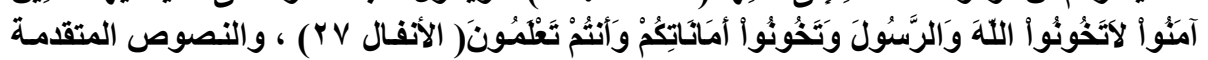

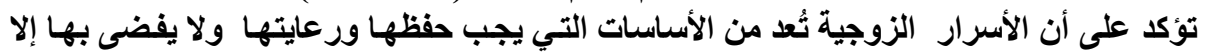


ولا يجوز للعميل التنصل من الالتزام بالسرية بدعوى أنها من الالتزامـات التي

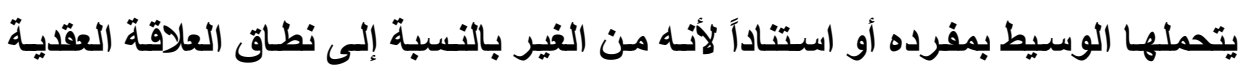

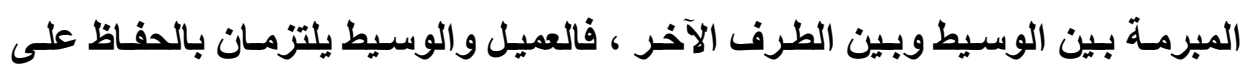

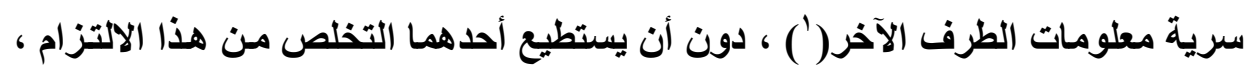

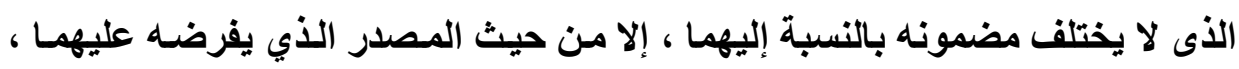

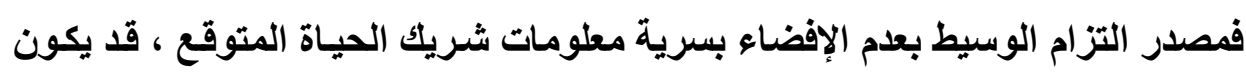

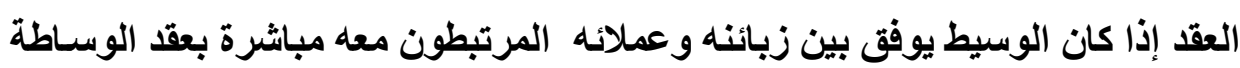

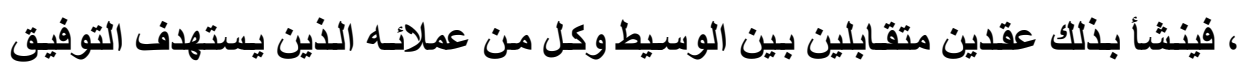

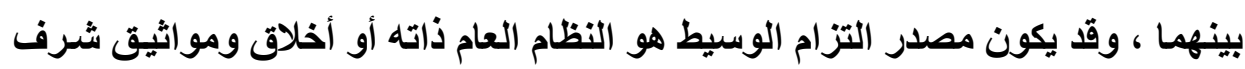

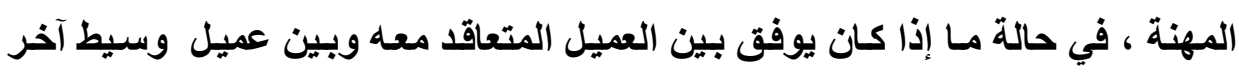

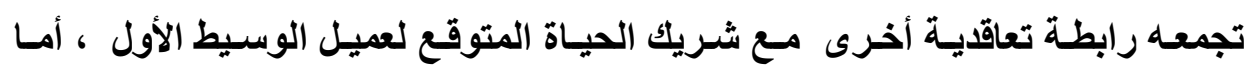

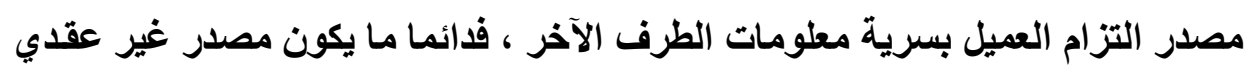

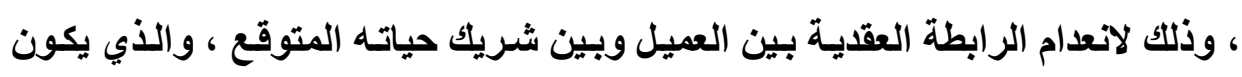
بالنسبة إليه لحظة التعاقد مع الوسيط شخصاً مجهولاً.

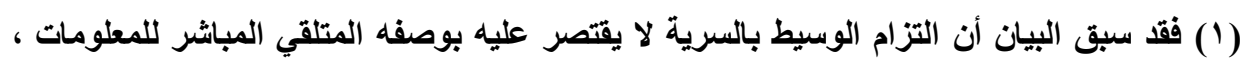

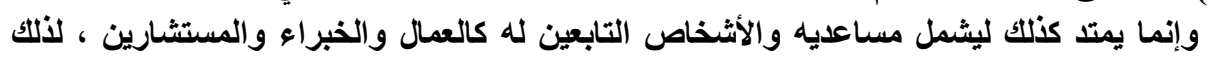

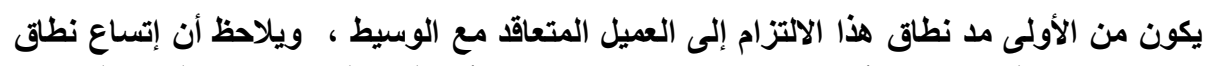

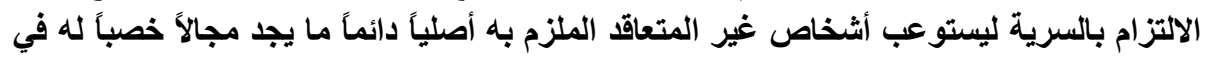

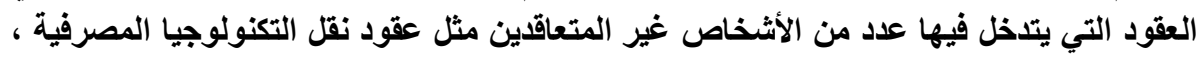

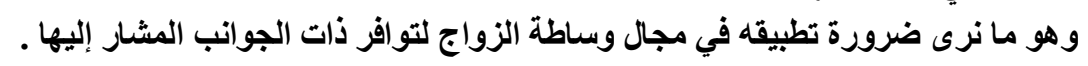

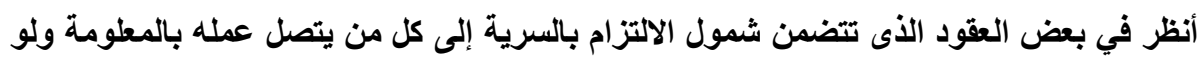

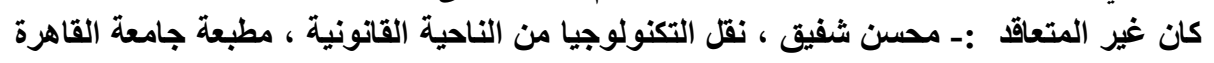

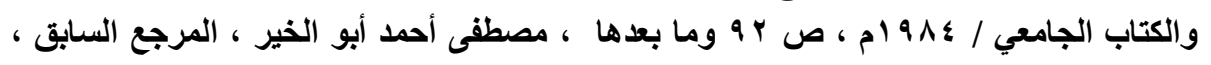

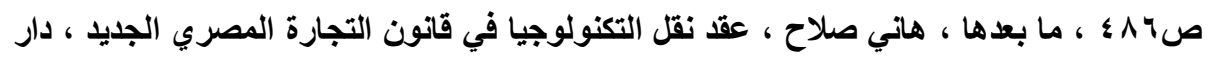

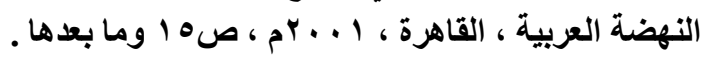




\section{المطاب الثانى}

\section{الالتزام بالجدية والتمكين}

الالتزام بالجديـة والتمكين مسن الالتزامـات التى تفرضـها طبيعة عقد الوسـاطة

بوصفه المرحلة التى تمهر للزواج الشرعى ؛ ومن ثم يصطبغ بكثير من السمات التى تهمين على العلاقات الثرعية ، لتعكس مجموعة من المفاهيم التى تتحول لصور من الالتزامات التعاقدية ، ومن بينها التزام العميل بـأن يكون جـاداً فيمـا يرغبه من إبرام الزواج ، وينبئق عن هذه الجدية التزماً يرتبط بهاوهو أن يمكن العميل الوسيط من أن يجمـع بيــهـ وبـين العميل أو الطرف الآخـر فـى لقـاعات وحـوارات شـفهية مسن خـلال اجتماعات يخصصها لذلك ، لذلك نرى أنسه يكون من المناسب تنـاول هذا المطلب من

$$
\text { خلال القرعيين الآتيين :- - }
$$

الفرع الأول : مضمون التزام العميل بالجدية والتمكين.

الفرع الثانى : طبيعة وضوابط التزام العميل بالجدية والتمكين.

\section{الفرع الأول}

\section{هضمون الترام العميل بالجدية والتمهين}

يسعى وسيط النكاح إلى تحقيق جوهر مهنته بـالجمع بين طرفين فى رابطة شرعية ، وتستهدف معظم التزاماته المهنية تحقيق رابطة القبول بين العميل والشريك الآخر ، ومن أجل أن يتسنى للوسيط إنجاز هذه المهام المـاديـة التى تتطلب مهارات خاصة فى البحث والتحري وقدرات فائقة فى المناقشة والإقناع ، يتعين على العميل أن 
يكون جاداً فى شأن الارتباط الثرعي بالطرف الآخر(') ، وتتصرف مظاهر هذه الجدية

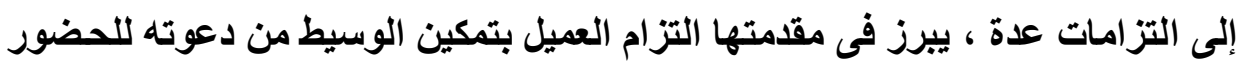

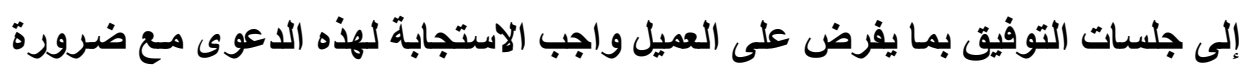

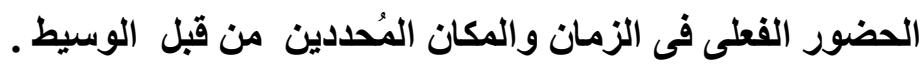

ولا ينحصر مضمون الالتزام بالجدية والتمكين فى هذا المفهوم الضيق ، بل

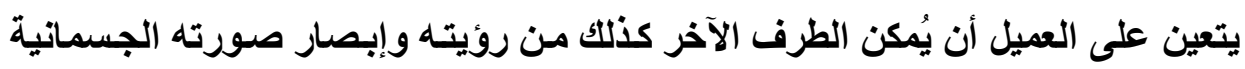

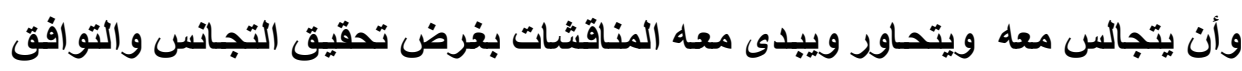

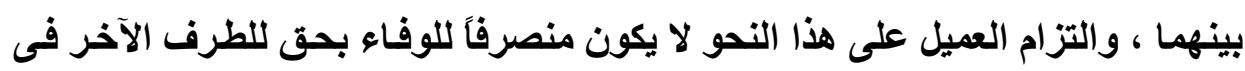

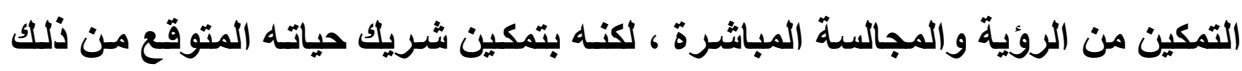

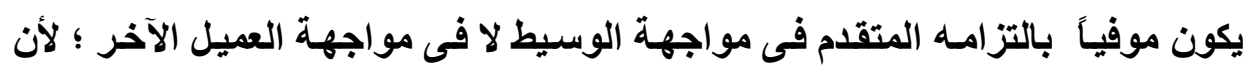

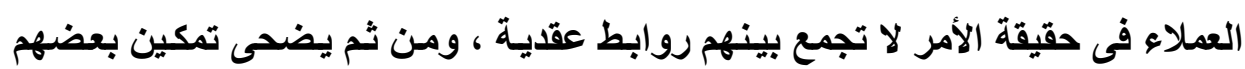

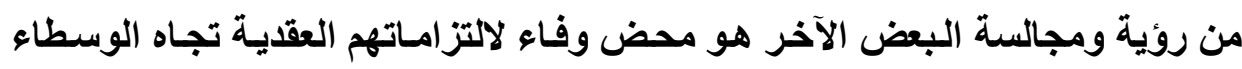

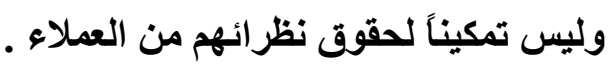

(1) ويبرز عنصر الجدية في فترة الخطبة لاى شرائع غير المسلمين ، حيث أحاطت الثريعة المسيحية

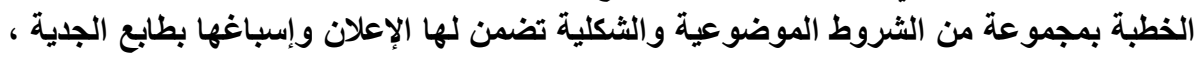

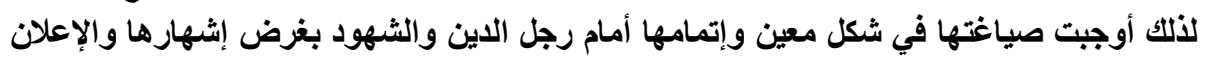

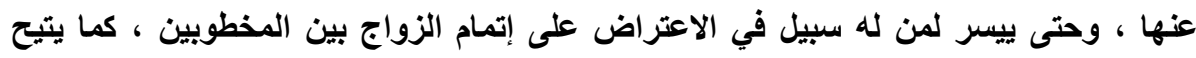

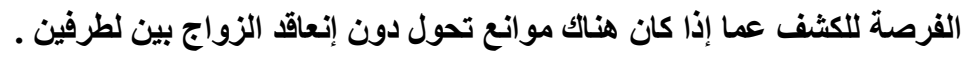

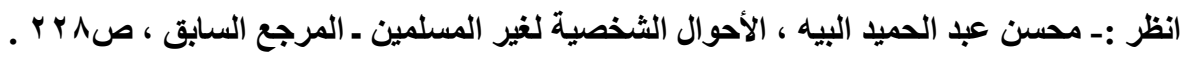




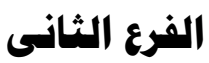

\section{طبيعة وضوابط التزام العميل بالجدية والتمكين}

فلئن كان قبول الطرف الآخر لثخص العميل كثريك حياة متوقع أضحى موقوفاً على المواجهة الماديـة المباثـرة ، بحيث يتـاح لـه التعرف الـواقعي بـثضص العميل ودراسة ميوله و أفكاره ، وحتى يتمكن من إبصار خصائصه الجسدية وصفاته العامـة ، لذا فإن الالتزام بالتمكين يضحي لزومـاً من طائفة الالتزامـات التي لا يتسنى استيفائها

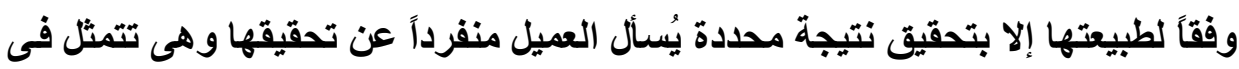

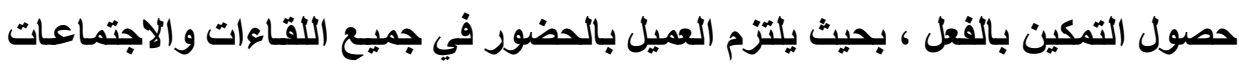

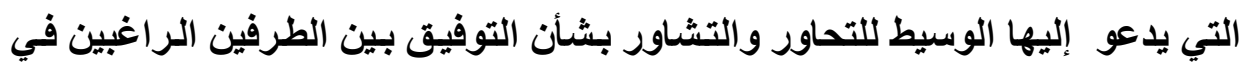

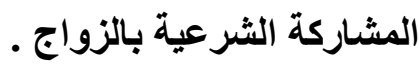

ولا يقوم الالتزام بالتمكين ولا يكون نافذاً بصورة فورية فى جانب العميل إلا بعد حصول إخطاره بمكان وزمان الجلسة ، فلا يتصف العميل بالتقصير في الوفاء بالتمكين إلا بعد التحقق من وصول إخطاره بحضور جلسات التوفيق إلى عمله اليقيني، فإذا عزف عن الحضور لعدة مرات متوالية دون عذر مقبول ورغم إخطاره ، فإنه تعتبر

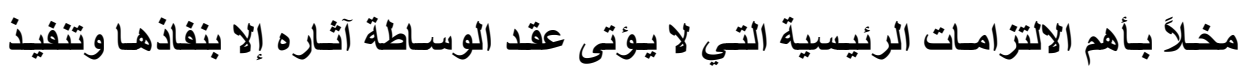

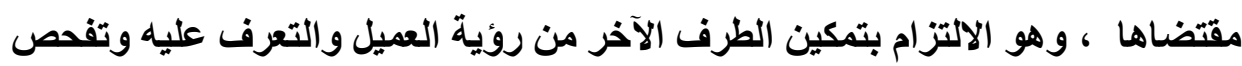
خصائصه الفكرية وإبصار صورته الجسمية. ولا يتوقف نفاذ الالتزام بـالتمكين على استيفاء واجب إخطار العميل بجلسات التوفيق والروية فحسب ، فهناك مجموعة من الضوابط الأخرى التي ترفع عن العميل

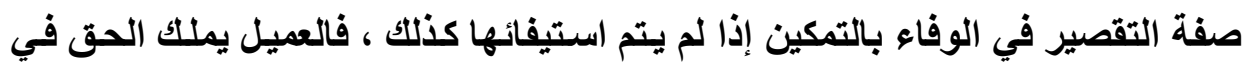


الامتنـاع عن الحضور إلى الجلسة إذا كـان الزمسان والمكـان المخصصان لعقدها غير مناسبين وفقاً لتقديره أو لأحواله ، ويخضع حق العميل في هذه الحالـة لرقابـة القضاء الأي يملكك اعتبار مسلك العميل متعسفاً في الامتنـاع عن الحضور من عدمسه ، فهنـاك حالات تؤكد بذاتها حق العميل في الامتناع عن الذهاب إلى جلسة التوفيق ، كمـا إذا تـم إخطاره من قبل الوسبط بحضور جلسة ليلية متأخرة ، أو تحديد ميعـاد يتعارض مـع مواعيد العمل الوظيفي للعميل ، أو يكتشف العميل بعد إخطاره أن مكان الانعقاد تحيطها

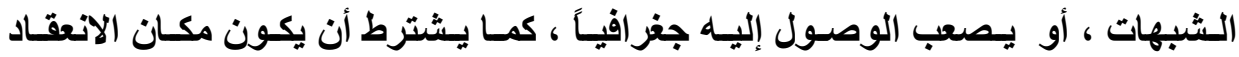
محايداً، ويحق للعميل الحق في الامتناع عن الحضور إذا ما دعاه الوسيط للحضور في منزل الطرف الآخر أو مكتبه أو في مكان يتبعه .

وخلافًَ للقيـود الزمنيـة أو المكانيـة التـي يتوقف التزام العميل بـالتمكين على انتقائهـا ، هنـاك ضـوابط أخرى يجب تحري توافرهـا في نطـاق هذا الالتزام ، وذلكك كالثرط الكمي لعدد جلسات الحضور ، إذ من غير المقبول أن يلتزم العميل بـالتمكين دون حدود عدديه قصوى ، بل يجب أن يكون دعوته للحضور ذات طابع زمني مؤقت ، لأن عقد الوساطة من العقود الفورية التي يتم إبرامها وإنجاز الالتزامـات الناشئة عنها جملة واحدة ، وهذا العقد وإن تراخى فيه الالتزام بـالتمكين زمنياً إلى مـا بعد إبرامـه وحتى يتحقق الالتزام بايجـاد الطرف الآخر بخصائص واشتراطات معينه ، إلا أن هذا التراخي لا يخلع عن عقد الوساطة الصفة الفورية لا يضفى عليه مفهوم العقد الزمني ، لذلك لا يمكن إلزام العميل بمقتضاه أن يحضر جلسات الحوار والتوفيق بصورة أبلية وكلما تم دعوته لذلك ، فلابد إذاً أن يكون هناك حدود تعاقدية مقبولة ثُقلص من نطاق الالتزام بالتمكين كلما خرج عن إطار المقبولية وتجرد عن الفائدة ، وبصفة عامة ، فإن فشل المفاوضات في إحدى الجلسات يعد من الأسباب التي ينقضي بها الالتزام بـالتمكين 
في حق العميل ، ويرجـع ذلـك لانعـدام أصـل الفائدة مـن الحضور ، كـللك فبإذا التـزم بالتمكين يزول بعدم تحقق القبول الموجب لاستمرار التجالس والحوار . وبالنسبة للاور الذي ينبغي أن يلعبه الوسبط في جلسات الحوار والتوفيق ، فإنه ينقسم إلى أمرين يمثلان التزامان يتفرعان عن التزامه بالتوفيق ، فيجب عليه ابتداءً أن يتولى عملية التعريف بـالطرفين والتعارف فيمـا بينهما ، ثم يبدأ بإدارة جلسة الحوار بسلوك جميع السبل المشروعة لإظهار مزايـا وخصائص الطرفين ، وإحداث نوع من الألفـة والتجـانس بينهمـا ، والحلـول محل عميلـه في التعبير عن أرادته في الارتبـاط بـالطرف الآخر ، ومحو التعثر الذي يمكن أن يقـع فيـه العميل للإفصـاح عن رغباتـهـ ومشاعره وشروطه الخاصة ، وتدارك الخجل الذي يمكن أن ينتاب العميل ويشكل عائقًاً يحول دون إظهار إعجابه أو نفوره من العميل المقابل . بيد أن اتساع حدود الدور المنوط بالوسيط إتمامسه جلسات الحوار ، لا يخولهـ الحق في الاستقلال والتمتع بـإدارة جلسات التوفيق منفرداً ، فالوسيط لا يتعدى دور الموفق الناقل لرغبات الطرفين واشتراطاتهما الشخصية ، ومن ثم فلا يسوغ لـه احتكار تفاصيل الجلسة والتحكم في مجرياتها ، فلا يستطيع لذلك أن يحتج بمقتضيات الالتزام بالتوفيق بأن يمنح لنفسه الحق في السيطرة الكاملة على الحقوق الأسساسية للطرفين في التحـاور ، لـلكت يملك طرفي علاقـة الزواج المتوقعة عزل الوسـيط عن إدارة عمليـة التوفيق والحوار ، وأن يستقلا بإرادتيهما المجتمعة عن الوسيط وينفردا بإدارة الحوار والتوفيق بنفسيهما وبمعزل عن تلخله ، لأن الوفاء بالالتزام بإدارة الحوار فى جلسات التوفيق بوصفه أحد نتائج التمكين يمثل واجباً على الوسبط ولا يشكل حقاً من حقوقه ، لذلك فلا يجوز أن يتمسك بالوفـاء بالتزامسه بـالتوفيق فى صورة إدارة المناقشـات فى حالة اتفاق طرفى علاقة الزواج المتوقع على عزل الوسيط عنها ، إلا إذا مارس إزاءه 
الطرفان غثاً وتدليساً قاصدين من عزله عن الوساطة التنصل من الوفاء بأجره مثثلاً، فهنا ينشأ الحق للوسيط فى التمسك بحضور الجلسات والوفاء بالتزامه بالتوفيق مـا دام العميل قد نفذ التزامه بالتمكين ، ويستحق الوسيط عندئذٍ أجره كاملاً ولو أصر الطرفين

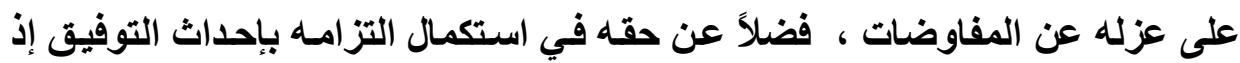
قدر الوسيط احتمال وقوع التغرير بأحد الطرفين نتيجة غيـاب الوسبط بـالعزل ، أو إذا كانت إدارة الحوار بين الطرفين بدون حضور الوسيط يمكن أن تؤدي لانعقاد مسئوليته المدنية أو الجنائية.

وعلى الرغم من قبـول اعتبـار الالتزام بـالتمكين مـن الآثـار الناجمـة عن عقد الوسـاطة وأن العميل يتحمـل عبء الوفـاء بـه بمفـرده ، إلا أنسه لا يمكن إنكـار الطبيعة الخاصة لمحل الالتزام بـالتمكين والتي تتجسد في عدم موائمـة التنفيذ العيني الجبري لهذا المحل بسبب تعلق الوفاء به بمحض حرية شخصية للعميل ترتبط بحقه في الإقامـة والتنقل دون قيود (') ، بما يستتبع عدم جواز إجبار العميل على حضور جلسات التحاور والتوفيق لارتباط إمكانية حضوره بمحض تقدير شخصى لله وبحق من حقوقه اللصيقة الأى يقر موقفه من استعماله بصورة فرديـة دون رقيب ، وهذا هو مـا يؤدى لانعدام

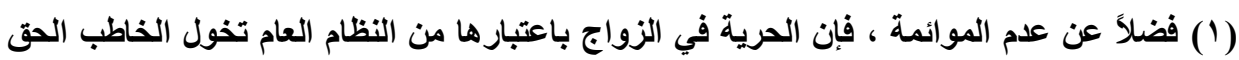

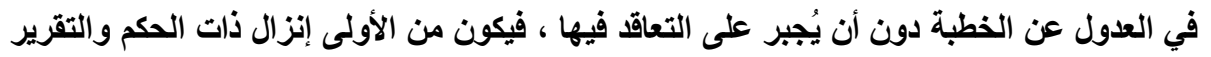

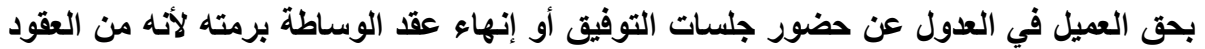

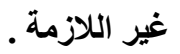

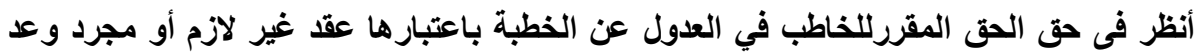

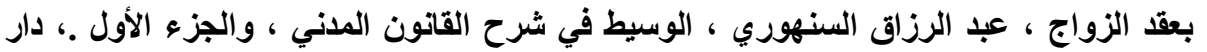

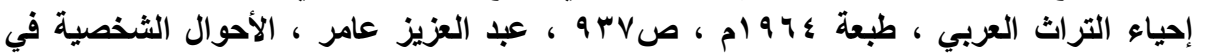

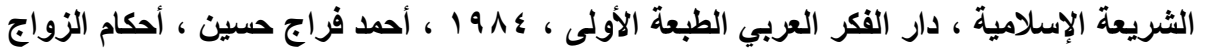

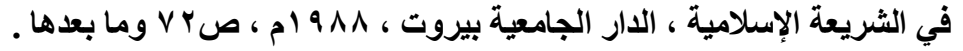


فرصة التنفيذ الجبري على العميل إذا مـا قصر فى فى الوفاء بالتمكين وأعرض جانباً عن الحضور إلى جلسات التوفيق.

وغني عن البيان ، فإن تمكين العميل للوسيط من حضور جلسات التوفيق يجب

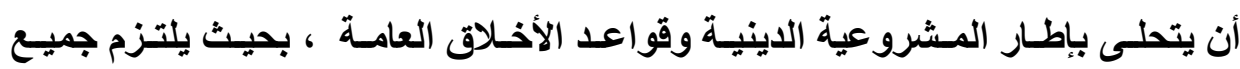

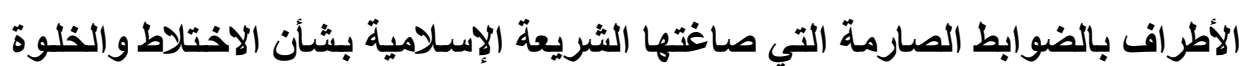

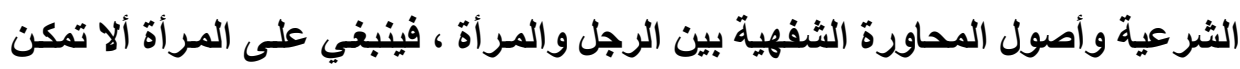

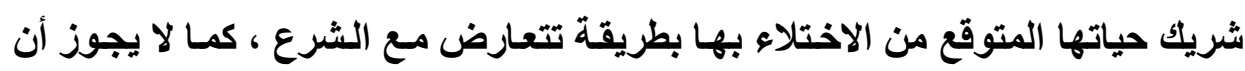
يطرح الأطراف أموراً غير مقبولة تتعلق بالرغبات الجنسية مثُلاً وبدعوى أنها من الأن

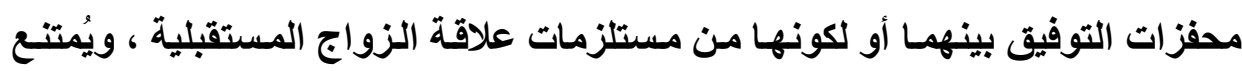
على جميع الأطراف كذلك الخوض في إبراز الخصائص الجسدية للعملاء في جلسات الحوار على نحو يكثف العورات ويفضح الأسرار أو ينتهك الخصوصيات الذاتية.

\section{المطب الثالث}

\section{التزام العميل بأداء الأجر}

إن حق الوسيط فى الأجر من الحقوق الأساسية له ، ويقابل هذا الحق التزام من

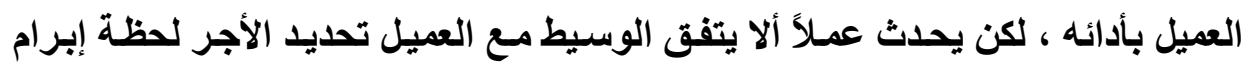

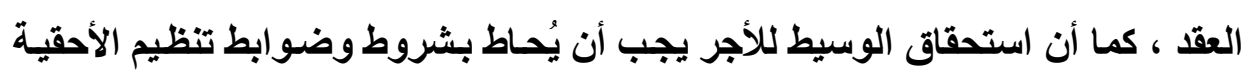
فيه ، لذلك يكون من المناسب تناول هذا المطلب من خلال الفرعيين الآتيين:-

$$
\text { الفرع الأول : طريقة تحديد أجر الوسيط. }
$$

الفرع الثانى : شروط التزام العميل بأداء الأجر. 


\section{الفرع الأول}

\section{طريقة تحديد أجر الوسيط}

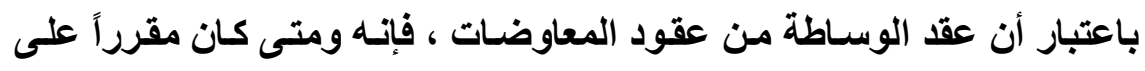

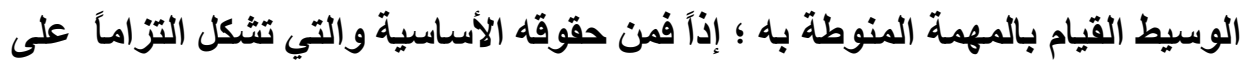

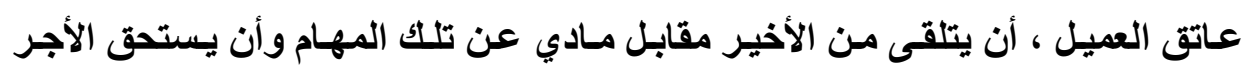

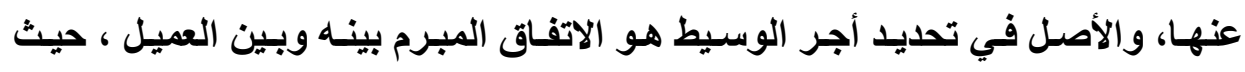

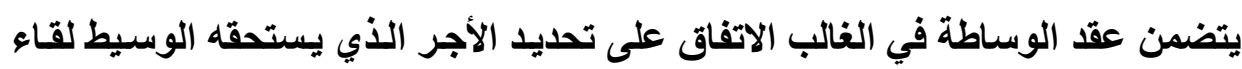

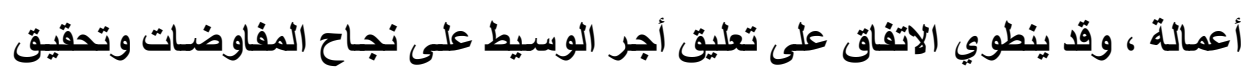

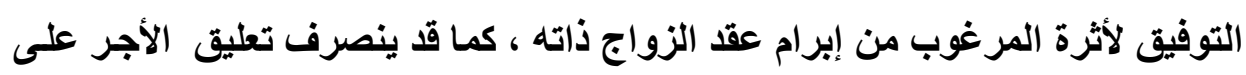
حصول الخطبة كمرحلة تمهيدية للزواج النهائى.

بيد أنه إذا لم يتضمن عقد الوساطة ما يحدد أجر الوسيط بسبب سكوت الطرفين

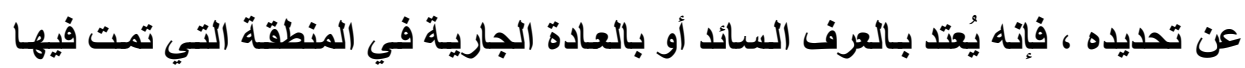

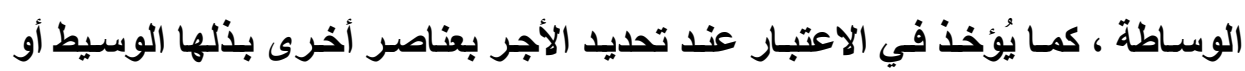

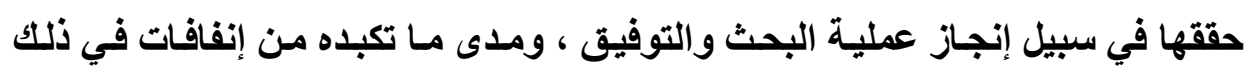

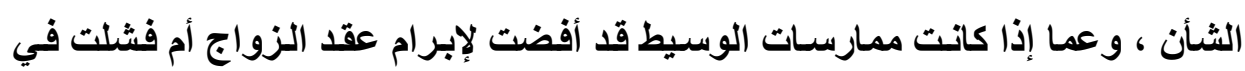

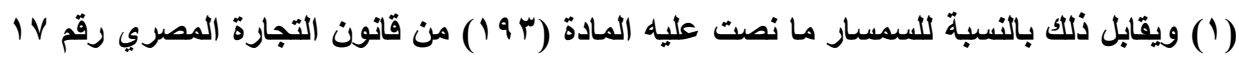

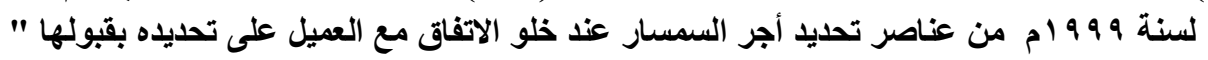

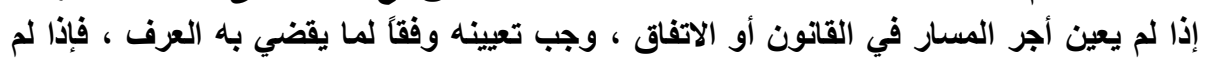

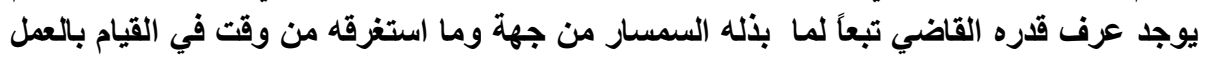

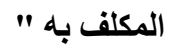

أنظر في ذلك بالتفصيل :- أحمد بركات مصطفى ، العقود التجارية وعمليات البنوك ، المرجع

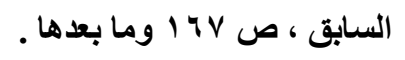


وبطبيعة الحال لا ياخل ضمن عناصر تحديد أجر الوسيط ، عند خلو الاتفاق عن

تحديده ، ما يحققه الوسيط من نجاح في توفير شريك حياة بمزايـا وخصائص فائقة ، لأن من التزامات الوسيط الرئيسية ، البحث الحثيث عن شريك الزواج بأعلى وأرقى خصائص إنسانية و جسدية مُمكنة ووفق مواصفات مطروحة على الوسبط سلقاً ، لذا فلا يلخل ضمن عوامل تحديد أجره ، أن ينجح الوسبط فى تحصيل مواصفات ومزايـا جسدية وماديـة في شريك الحيـاة لا تتناسب مـع توقعات العميل ومتطلباتـه أولـم يكن بحسبانه أن يحوزهـا زوج المستقبل ، فعندئـن لا يحق للوسيط مطالبـة العميل بـالأجر الذى لم يتضمن العقد تحديده بأن يقيم عناصر تقدير هذا الأجر معولاً على أساس نجاح مساعيه فى الحصول على شريك حياة متميز يحمل من الخصائص الإنسانية والماديـة الفريدة ، ومن ثم لا يجوز أن يطالب الوسيط العميل بأجر كبير لقاء هذه المميزات التى لم يكن يتوقعها العميل ، إنما يتم تحديد أجره وفقاً لمـا بذلهـه من مساعي ومايقضى بـه العرف الجارى على النحو المتقدم ، حيث إن الحق فى الأجر يرتبط بقدر المجهودات التى يقدمها الوسيطولا تندرج النتائج التي يحققها فى نطاق معايير تحديد أجره الذي

خلا العقد من تحديده(') - (')

إلا أنه يستثنى من ذلك إذا انطوى الاتفـاق من مبلئسه ، على تحديد أجر معين

للوسيط ، يتناسب مع المزايا التى تعهد للعميل أن يحصلها لصالحه فى الطرف الآخر ،

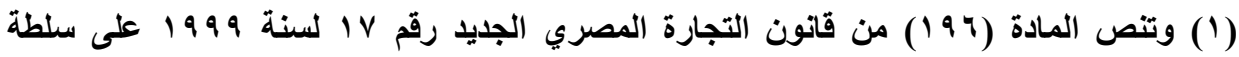

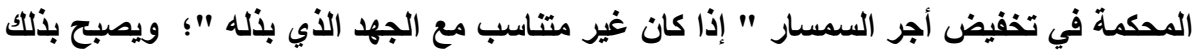

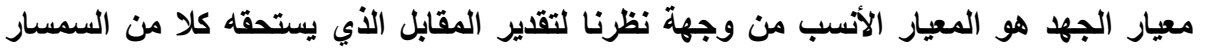

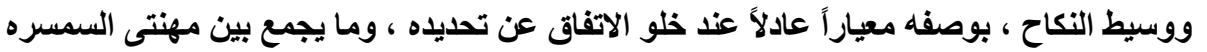

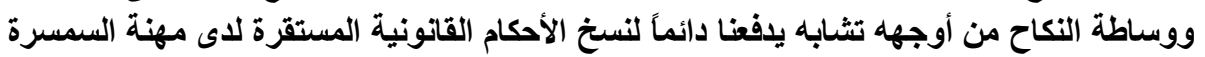

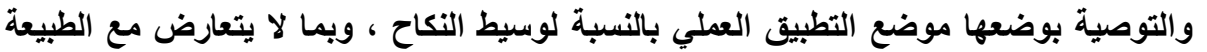

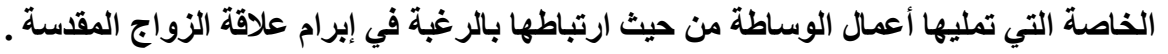


فإذا نجح الوسيط فى البحث والتوفيق مع من يتمتع بهذه المواصفات المميزه والمُحفزه للزواج ، فإنه يستحق عندئذٍ الأجر المتفق عليه ولهو كـان باهظاً ؛ لأنسه أوفى بـالالتزام الأى يقابل تلقيه لهذا الأجر ، ويكون أساس صحة استحقاق الوسيط للأجر الذى يزيل عما يقضى به العرف السائد هو الاتفاق المسبق على توفير شريك حيـاة بمزايـا معينة يتمنسى العميل تحقيقها فيـه بوصفها أعلى مـن سقف مطالبهله وتوقعاتـه في الارتبـاط الشرعي ، وأن العميل ارتضضى بزيـادة أجر الوسـيط مقـماً فـى مقابـل تحصيل هذه المواصفات الخاصـة ذات الطبيعة المرغوبـة لايسه ، كمـا يجوز للوسبط أن يضع عدة مستويات متدرجة لأجره ، بحيث تتوازى مع مستويات مقابلة لطبيعة المزايـا الإنسانية والخلقية التي يمكن أن يوفرها للعميل في شريك حياته المتوقع.

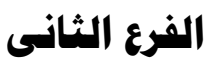

\section{شروط التزام العميل بأداء الأجر}

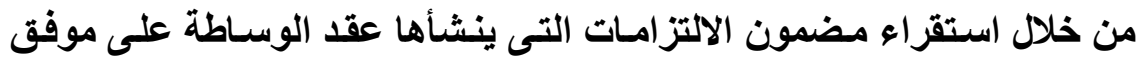
الرغبات الشرعية فى الزواج ، يمكنـا اعتبـار استحقاقه للأجر رهيناً بتحقق الشروط والوضابط الآتية :-

\section{الشرط الأول : أن يكون الوسيط هكاً بالوساطة هن قبل العميل.}

يشترط بـاعة أن يكون وسيط الزواج مكلفاً بالفعل من قبل العميل بالبحث عن شريك الحياة الزوجية ، إذ يتعين أن يستند الوسيط في عمله إلى سند قانوني يبرر حقهـ في تلقى الأجر ، هذا السند بلا شك هو عقد الوساطة الذي ينشأ لصالحه التزامًا أساسياً على العميل بالوفاء بأجره ، فبإذا كـان الوسبط غير مكلف من قبل العميل سواء كسان 
الأخير يمثل الرجل أو المرأة ، فـلا يستحق حينـــ ثــة أجر لانتفـاء السبب القـانوني لاقتضائه مهما كاتت المساعي التي بذلها. ونتيجة مباشرة لما تقدم ، يستحق العميل أجره من الطرف الذي كلفه مباثرة بالبحث والوسـاطة لإيجـاد الشريك الآخر للحيـاة الزوجيـة ، ولا يحق لـه الرجوع على الطرف المقابل خاصة إذا كان الأخير قد كلف وسيطًا آخر للبحث ، فيرجع كل وسيط على الطرف الذي تعاقد معه وقام بتكليفهـ بمهام التوفيق ، فباذا كلف طرفي العلاقة الزوجية المحتملـة وسيطاً واحداً لإيجـاد الطرف الآخر ، استـق الوسيط أجراً عن الوساطة من كلا الطرفين ، إذ لكل علاقة تعاقدية يبرمها الوسبط مـع عملائه المتعددين كيان مستقل عن العلاقة الأخرى ، ولا وجه للتضامن في سداد الأجر في حالهه تكليف الطرفين ذات الوسيط بالبحث ؛ فيقوم بالتوفيق بينهما من خلال روابط تعاقديه مستقلة ، وبدون أن ينشأ على الطرفين التزاماً تضامنياً بالوفاء بالأجر ، فإذا اتفق العميل وشريك الحياة المقابل على أن يتحمل أحدها أجر الوسيط بالكامل ، فيكون للوسيط رغم ذلك

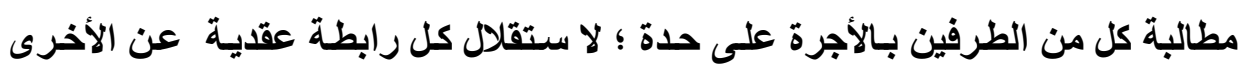
فيما ترتبه من آثار ؛ ولأن كل من العميلين يعتبر من الغير بالنسبة للاتفاق المبرم ببين

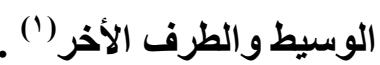

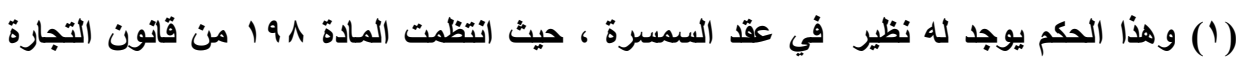

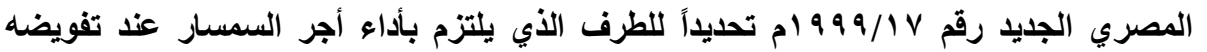

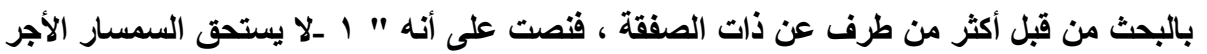

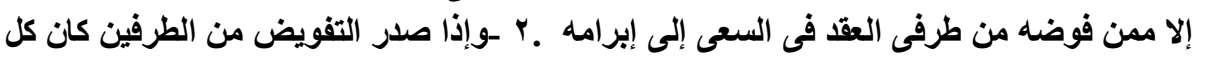

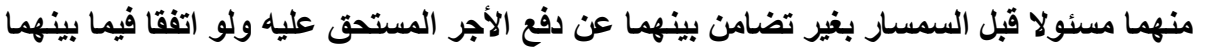
على أن يتحمل أحدهما الأجر بأكمله." 


\section{الشرط الثاني : أن يؤدي الوسيط المهام المُكف بها بمقتضى عقد الوساطة.}

يجب لاستحقاق الوسيط للأجر ، أن يتكلل مسعاه بالنجاح في إيجـاد الشخص

المطلوب وفقاً لمواصفات العميل المرغوبة ، ثم استنفاد مرحلة التوفيق بين الطرفين ؛ بحيث يتحقى لاى كل منهما القبول المبدئي بالطرف الآخر ، وأن يعرب كل من طرفى علاقة الزواج المحتملة بموافقته المبلئية على مواصفات الطرف الآخر ، وأن تحوز العناصر الشخصية لكل منهما وظروفه الواقعية والمادية الرضا الحر المستتير للطرف الآخر ، بحيث يهيأ هذا القبول لإمكانية غير مؤكدة للاخول فى إبرام عقد الزواج النهائى أو إتمام مرحلة الخطبة الموطئة له.

ويلتزم العميـل بسداد أجر الوسـيط بمجرد أن يـوفي الأخير بالتزامـه المقابـل بالحصول على الطرف الآخر والتوفيق بينهما حتى مرحلة القبول المبدئي للزواج ، ولا يتوقف أجر الوسيط على إبرام عقد الزواج ذاته أو أتمام الخطبة ، ومن ثم فلا يؤثر في مئي أجر الوسبط استكمال الطرفين للمراحل التمهيدية للخطبة والزواج أو عزوفهمـا عن إن ذلك ، كما لا يجوز المساس بأجره على أساس حصول خلافات ماليه أو اجتماعية أثناء ما قبل إبرام الزواج وما بعد انعقاده ، إلا إذا اتفق على غير ذلك(') . وغنـي عن البيـان ، أن الوسيط لا يستحق الأجر فـى مرحلـة الوفـاء بالتزامـه بالبحث عن الطرف الآخر إذا فشلت مساعيه في إيجاد شخص ما يقدمـه للعميل تمهيداً

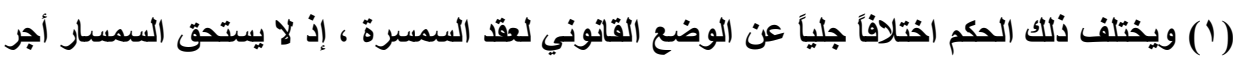

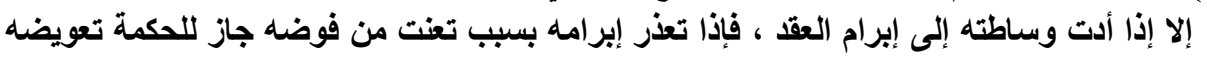

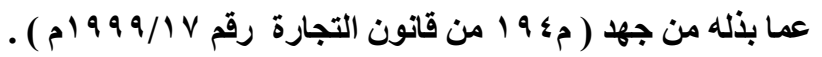

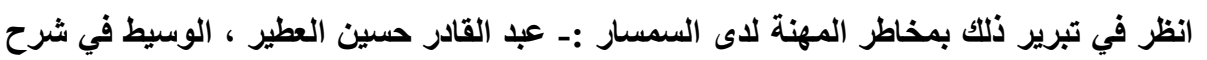

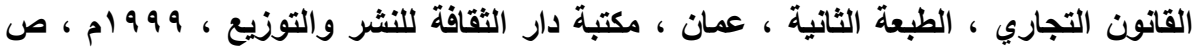


لاستكمال مراحل التوفيق ، فمناط استحقاق الوسيط لأجره فى هذه المرحلة هو تحصيل الطرف الآخر بصفة مبائية وبصرف النظر عن حيازته للصفات والاشتراطات التي يتطلبها العميل من عدمه ، فطبيعة التزام الوسيط بالبحث لإيجاد الطرف الآخر يتمثل في بذل العناية الواجبة في البحث كوسيط مهني محترف من طائفة الوسطاء الذين يعملون في ظروف مشابهة ، لذلكك كان طبيعياً أن يُحرم من الأجر الذي يستحقه بسبب عدم

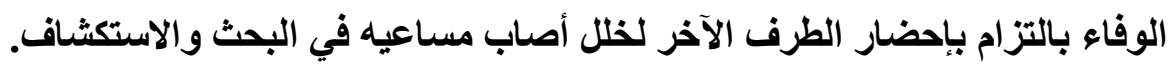
ولا يقتصر حرمـان الوسيط من الأجر على ثبوت إخلالهه وقعوده عن الوفاء بمقتضيات البحث الجاد الثنامل عن شريك الحياة المتوقع ، فهنـاك من الاتفاقات التي تنصرف فيها إرادتي الطرفين على أن يستحق الوسيط الأجر ليس بمجرد تحصيل شريك الحياة ونجاح عملية البحث والتحري فحسب ، بل يتعين على الوسيط تحقيق التزامسه بإيجاد شريك حياة تتو افر فيه ذات الاشتراطات التي يرغبها العميل دون نقصان فيها ، كاثتراط العميل مهنة محددة في شريك الحياة ، أو دخل مالي ثابت ، أو صفات جسمية بالية وحسية معينه ، وفي هذه الحالات يتراخى التزام العميل بسداد الأجر حتى تتجح مساعي الوسيط فى تحصيل الاشتراطات المادية والمعنوية ومواصفات الثكل والصورة والجسم التي يرغبها العميل في شريك حياته ، و التى عزم على ضرورة توافرها بصورة ملزمة لا يتراجع عن اشتراطها فيه(')

( ) و المسألة ترجع برمتها إلى مضمون الاتفاق من الناحية العملية ، فأغلب الوسطاء يتشرطون عملاً

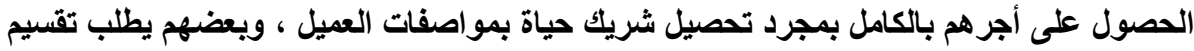

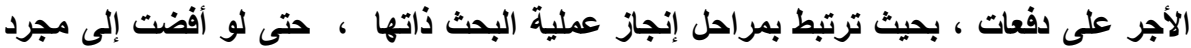

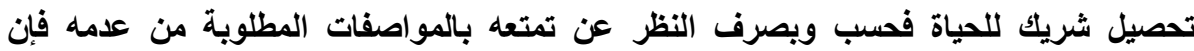

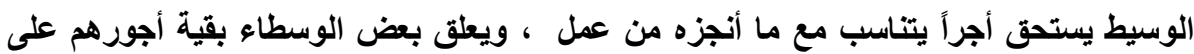
تكرار البحث حتى يرضى العميل بالحصول على الثريك الحائز على مواصفات الزئل الزوج الأمثل بالنسبة إليه . 
وتعليق الأجر في هذا الصدد ، يوضح الفارق بين طبيعة التزام الوسيط بالبحث عن الطرف الآخر من ناحيـة وطبيعة التزامـه بتحصيل الشروط المتطلبـة في الزوج المحتمل من ناحية أخرى ، حيث ينطبق على الالتزام الأول ضرورة بذل العناية المعتادة لتنفيذه ، ويتوجب على الوسبط في الالتزام الثاني بتحصيل الصفات المطلوبة في شريك الحياة كنتيجة محددة لا يستطيع الوفاء بغيرهـا ؛ وبذألك يكون منـاط استحاق الأجر فى الى الالتزام بالبحث محدداً بحسب الاتفاق المبرم مع العميل ، فقد يستحق الوسبط أجرة إذا اتفق على ذلك يمجرد القيام بالعنايـة الواجبة في الالتزام بالبحث ، وقد يعلق الطرفـان الأجر على إيجاد الطرف الثانى كنتيجة لعملية البحث سواء حاز مواصفات العميل أم لم تتوافر فيه ، أما فى نطاق الالتزام بتحصيل شروط معينة فى الطرف المقابل فِان الأجر لا يستحق للوسيط إلا بتحقيق نتيجة محددة مسبقاً وهى تحصيل هذه الشروط بالفعل و إلا يسقط حقه فى الأجر (').

\section{الشرط الثالث : ألا يكون الترام العميل بالأجر همعقاً على شرط.}

ذكرنا فيما تقدم ، أن الوسيط يستحق مقابل مجهوداته من الأجر المتفق عليه في العقد ، أو الذي يقدره القاضـي عند خلو العقد من تحديده ، بمجرد أن يصل لمرحلة التوفيق بين العمـلاء الراغبين فى النكـاح ، وأن يكون التوفيق ناجمـاً عن دور فعـال للوسيط في التقريب بين الطرفين حتى تلتقى رغباتهما المتبادلة بشأن عناصر الزواج وشروطه الأساسية ، دون أن يتراخى أو يتوقف استحقاق الأجر حتى إبرام عقد الزواج

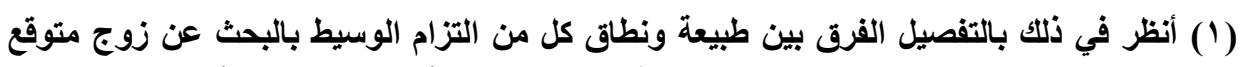

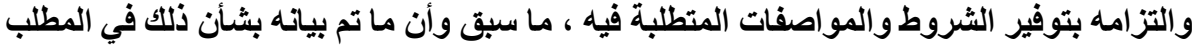
الأول من المبحث الأول من هذا الفصل. 
ذاته ، أو إتمام الخطبة بينهما ، فتلك الوقائع لا شأن للوسيط بها ، ولا تندرج من الأصل ضمن نطاق التزاماته التعاقدية(')

لكن الحكم المتقدم ، لا يمنع أن يتضمن عقد الوساطة تعليق التزام العميل بـأداء الأجر ، على شرطواقف أو فاسخ ، فإذا تم التعليق الأجر على شرط إبرام عقد الزواج وتوثيقه رسمياً ، فلا يستحق الأجر إلا بعد تحقق الشرط بإبرام الزواج بالقعل إذا كـان الثرط واقفاً ، ويلتزم الوسيط برد الأجر الذي تلقاه عند إبرام العقد إذا مـاكـان الشرط

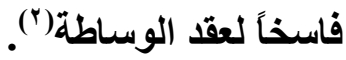
وحري بالإشارة ، أن التزام العميل بالوفاء بالأجر ، وإن كان يمكن تعليق نفـاذه على شرطواقف كان أم فاسخ، إلا أن أجره يكون مستحقاً ولا يلتزم برده إذا تسلمه في حاله بطلان عقد الزواج الذي يمثل إبرامه الثرط الذي علق عليه الالتزام بأداء الأجر ، طالما أن الوسيط لا يعلم بسبب البطلان ولم يشارك في التسبب فيه ؛ ولعل ما يبرر ذلك

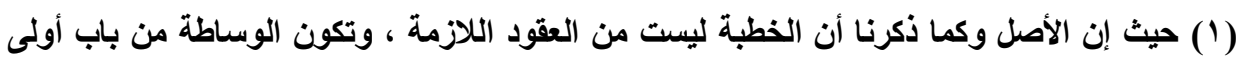

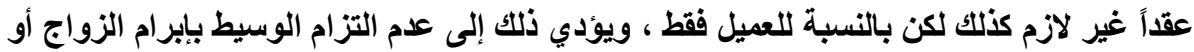

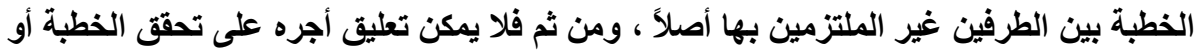

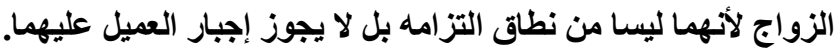

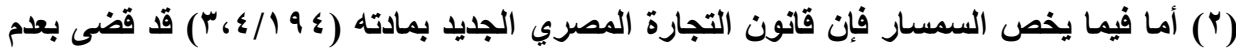

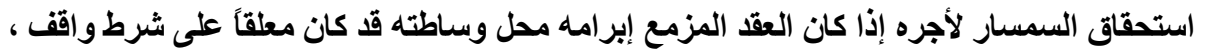

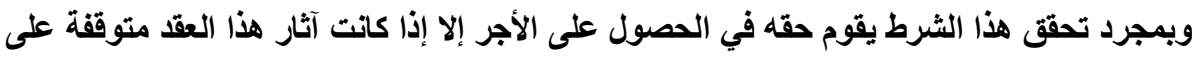

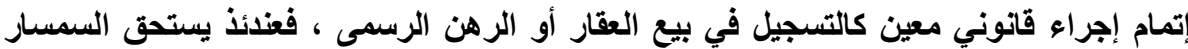

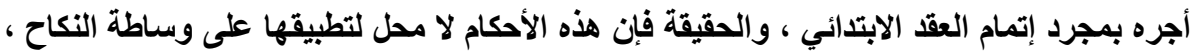

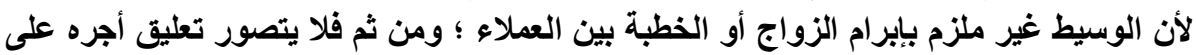

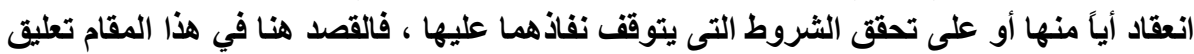
عقد الوساطة نفسه على شرط وليس تعليقه على عقد الزواج أو الخطبة .

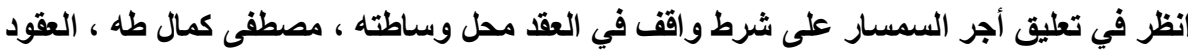

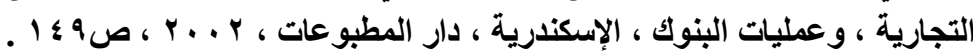


هو أن مهمة الوسيط تنحصر في التوسط بغرض التوفيق الأي يمثل تمهيداً لإبرام عقد الزواج ، ولا تنصرف مجهوداته المهنية إلى حد الالتزام بـأن يصل بـالطرفين لمرحلة عقد الزواج ذاتـه ، وإن جـاز تعليق أجره على هذه الواقعة المستقبلية غير محققة الوقوع ، إلا أنـه لا يجوز مطلقاً حرمانـهـهـ من الأجر إذا مـا شــاب عقد الزواج البطلان بسبب لا يرجع إلى الوسيط ولم يثبت أنـه شـارك في إحداثه بفعله ، ومـا ينطبق على البطلان ينصرف كذلك إلى انحلال عقد الزواج بالطلاق حيث لا يكون لانحلال هذا العقد أثراً على ما استحقه السمسار من أجر ، فيجوز له المطالبة بأجرة أو الاحتفـاظ بـه رغم حصول الطلاق بين العميل وزوجته (').

\section{الشرط الرابع : تحقق رابطة السببية بين نجاح التوفيق وسعي الوسيط.}

قد يبذل الوسيط مساعي جمة في سبيل إيجاد المواصفات وتحقيق الثروط التي يرغبها العميل في شريكه المتوقع للزواج ، وقد يقدم مجهودات كبيرة في سبيل التوفيق بين الطرفين للتمهيد لإبرام عقد الزواج بينهما ، لكن يشترط لأن يستحق أجره قانونـاً في الحالتين أن يكون سعيه ومجهوده المهني هو الذي أنتج حالة التوفيق الذي يعبر عنها بوجود موافقة مبئية أو قبول مؤقت لاى الطرفين بإبرام عقد الزواج ولو لم يتم إبرام بالفعل ، فإذا ثبت أن الطرفين الراغبين في الزواج ، كانـا على اتصال مباثر قبل

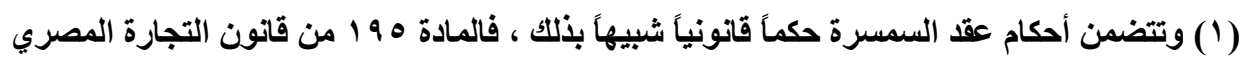

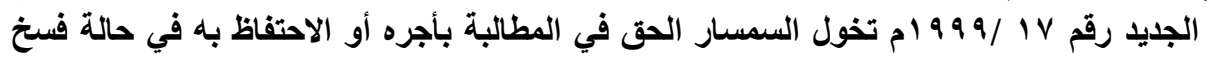

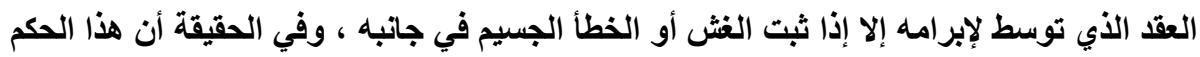

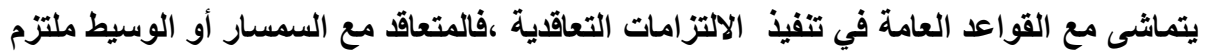

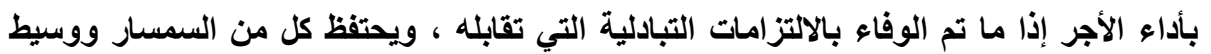

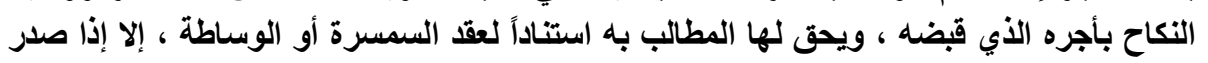

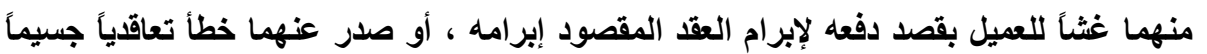

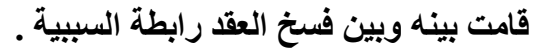


تـخل الوسبط ، أو تجمـع بينهمـا رابطة قويـة من المعرفة الثخصية السابقة ، أو تم التوفيق بينهمـا بواسطة مُوفق زواج آخر ، فبإن الوسبط المتعاقد لا يستحق في هذه الحالات أجراً ولو بذل جهاً غير منتج فى إحاث التوفيق ؛ لانتفاء رابطة السببية بين أفعاله ومساعيه ووسائل بحثه وبين وتحقيق رابطة الاتصال بين الطرفين وخلق حالة من التوفيق والاتسجام بينهما. 


\section{الخاتمة}

ـ فى ختـام هذه الدراسـة ، يمكنتـا استجلاء خلاصتها القانونيـة وإيجاز هـا فى النتائج

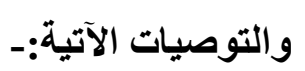

ا ـ مشروعية عقد وساطة النكاح فى الشرع والقانون ، لكن ينبغي أن تُحاط عملية الوسـاطة والتوفيق بين الراغبين في الزواج بمجموعة مـن الضوابط أهمها ، انتفاء الموانع الثرعية من النكاح سواء منهـا الموانـع المؤبدة أو المؤقتة ، و وألا

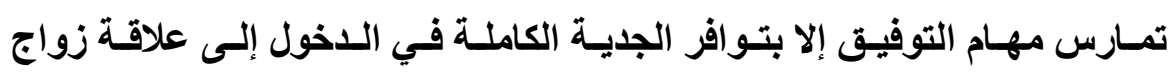
شرعية، ويتعين عدم الإفراط في تعيين الأوصساف والخصائص المتعلقة بالعميل لئلا تتنهك الحرمسات العورات ، ويحظر على الوسبط إبراز الخصائص الجسمية الخفية للعميل إلا ماكان منها مرتبط بآفة جسدية تـؤثر على قيام أو بقاء العلاقة الزوجية المتوقعة ، أو أن يكشف العيوب والاختلالات النفسية والعقلية التي لـم هـ تتحول بعد لمرحلة الجنون أو تلك التي لم تتنهي بعد بمرض نفسي أو عقلى مزمن

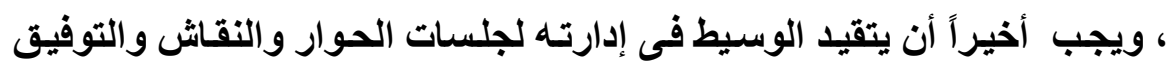

$$
\text { بقواعد ومحاذير الخلوة بين الرجل والمرأة. }
$$

r- أثثارت هذه الدراسـة تساؤلاً مهمـاً يتمثل فيمـا إذا كـان يمكن اعتبـار الدور الذي يلعبه وسبط التوفيق في سبيل إبرام عقد الزواج صورة من صور التعبير عن الإرادة التعاقدية بحيث يصلح لبناء أتفاق تعاقدي بينه وبين راغبي الزواج ، أم أن ما يقوم بـه وسيط الاتفـاق لا يتعدى مفهوم الأعمـال المادية أو الوقائع القانونية

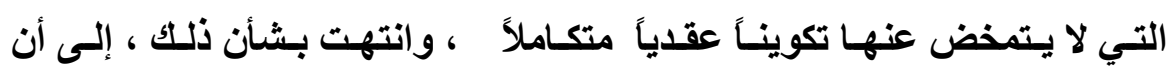
الوسـاطة بين الراغبين في الزواج تنشئ علاقات تعاقية بين الطرفين لا يمكن

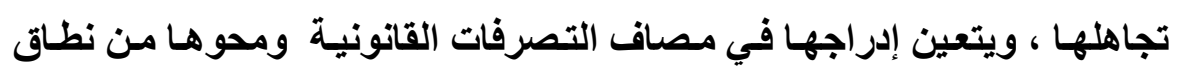


الوقائع القانونيـة ، خاصـة مـع هيمنـة المفـاهيم العقديـة على البنـاء الـواقعي فيها وكيفية التقاء الإرادات المتقابلة لطرفيها ، لذلك فهى تختلف عن فكرة الاتفاقـات السابقة عـن التعاقد وفكرة العقود التمهيديـة ، لـذلك يكـون مسن غيـر المقبـول تجريدها من أي اعتبار قانوني ، حيث في الوساطة يصدر إيجاب يلتقى بقبول على هن البحث والتوفيق بين شريكين يتوقعان الدخول في علاقة نكاح أصلية ، لذلك فهي تجسد ارتباط قانوني وعقد حقيقى قائم بين طرفيه .

r- ويتمتع عقد الوساطة بخصائص تميزه عن غيره من العقود ، فهو عقد رضسائى

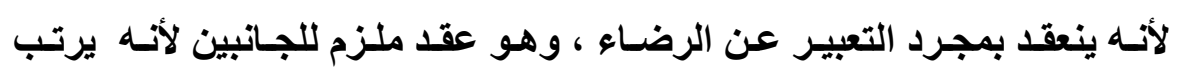
التزامات متقابلة في ذمة كل من عاقديه ، وهو عقد من عقود المعاوضات لأن كل من الوسيط والعميل يأخذ مقابلاً لما يلتزم به تجاه الطرف الآخر ، فضلاً عن أنسه

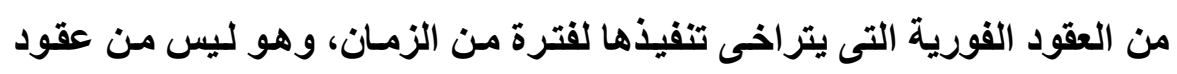

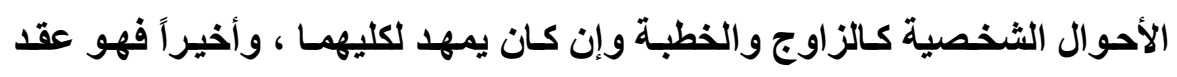
غير لازم بالنسبة للعميل باعتبـار أن حريـة الزواج الذى يهـف لإنجـازه متعلقـة

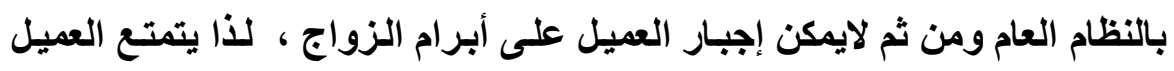
بحق العدول عن الوساطة دون قيد زمنى أو موضوعى. ع- بعد محاولة لإنزال التكييف القانوني الصحيح على العلاقة التعاقدية التي يمكن تصورها بين وسيط التوفيق وعملائه من راغبي الزواج ، من خلال مقارنـة لبيـان أوجه التقارب والاختلاف بين عقد وسـاطة النكاح الشرعي وغيره من الأنظمـة العقدية المُسماة والتي تتميز بوجود أصول مشتركة أو تشابه ظاهر بينها وبين الوسـاطة التوفيقيـة للزواج ، وبـافع استجلاء فرصـة إخضاع التكييف القـانوني

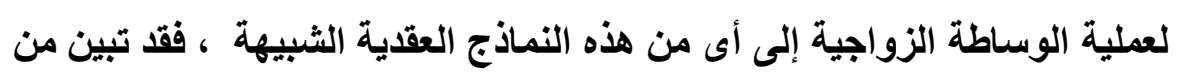
مقارنة الأنظمة العقدية الثبيهة بعقد الوسـاطة فى النكاح أن نقاط التوافق بينهم 
عسيرة المنـال ، حيث يـصب إنزال الكيوف القانونيـة المتنوعـة لبعض العقود القزيبة مـن مفهوم الوسـاطة ، وهذا مـا نخلص فيسه إلى أن عقد الوسـاطة بين راغبى النكاح من العقود غير المسماة فى القانون ، وأنسه يتعين على القضاء أن يجته فى ظلال وجود الفراغ التشريعى بأن يجري أحكامسه على أسساس تحري المقاصد العملية لأطر اف وسـاطة النكاح ، وأن يطابق هذه المقاصد على النظام القانوني للعقود المعروفة ، ليحدد الآثار الأساسية التي اتجه طرفاه إلى تحقيقها، وأن يستظهر الغايات العلية التي اتجه طرفا العقد إلى بلوغها. هـ تناولت الدراسة آثار عقد الوساطة ، فتناولت جميع الالتزامات البارزة التى يمكن أن تتولد عن عقد الوساطة بذمة طرفية ، وقد تمثلت أهم الالتزامات التى تقع على الوسيط بوصفه الطرف المهنى المحترف ، فى وجوب التزامسه بالبحث الجـاد عن شريك الحياة المتوقع ، ثم الالتزام بإيجاده على نحو بذات الخصائص والمواصفات

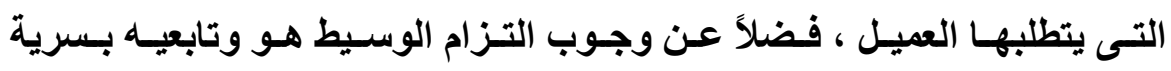
المعلومات التى تصل لعلمهم أثناء تنفيذ عقد الوسـاطة ، و والتزامسه بـالتوفيق بين الطرفين بوصفه الالتزام التعاقدى الذى تبرز فيه براعة الوسيط ومهارته على

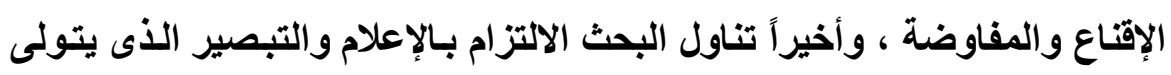
فيه الوسبط إعلام العميل والتتبيه عليه بجميع مخاطر علاقة الزواج أو الخطبة ولية التى يوشـك على إبرامها ، وتتنـوع طبيعة التزامسات الوسبط مسابين وجوب بـذل

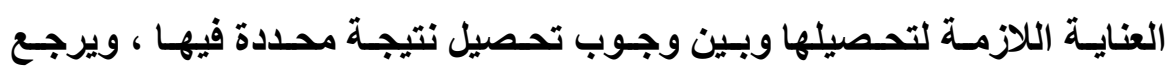
الاختلاف فى ذلك إلى مضمون الالتزام ذاته وأهميته بالنسبة لمصالح المتعاقدين

$$
\text { وتعلقه أحياناً بالنظام العام والآداب العامة. }
$$

جـ كمـا انتهـى البحث إلـى أن العميـل يتحمـل بمقتضى عقد وسـاطة النكـاح ثلاثـة التزامـات رئيسة ، فهو يلتزم كالوسيط بكتمـان سرية المعلومـات والبيانـات التى 
تصل لسمعه وبصره عن الطرف الآخر ، وعلى نقيض ذلك يلتزم العميل بالإفصاح عن جميع المعلومات الخاصة به التى تمكن للوسيط تنفيذ التزامه بالبحث والإيجاد والتوفيق والتبصير ، ومن بين الالتزامات التى استحدثتها هذه الدراسـة ، الالتزام بالتمكين ، حيث يلقى عقد وساطة النكاح واجباً على العميل بالحضور إلى جميع

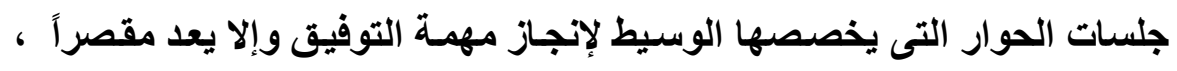

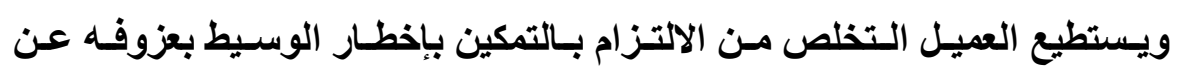
التزاوج عن طريـق الوسـاطة باعتبـار عقد الوسـاطة من العقود غير اللازمسة ، وأخيراً يلتزم العميل بـأداء الأجر المتفق عليه أو الذى يقدره القاضى عند عدم تحديده ، ويشترط لاستحاق الوسيط للأجر الذى يقابل أعماله ، أن يكون مفوضساً من العميل بالفعل ، وأن رابطة السببية بين مجهود الوسيط وحصول القبول بين الطرفين وذلك بأن يحدث التوفيق والانسجام بواسطة أفعاله.

V- ونوصى أخيراً ، بضرورة أن يتدخل المشرع المصرى بوضع قانون أو لائحة

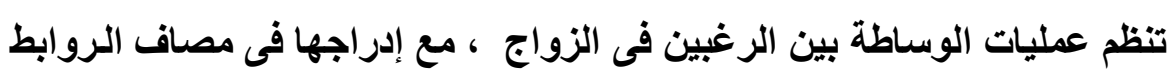

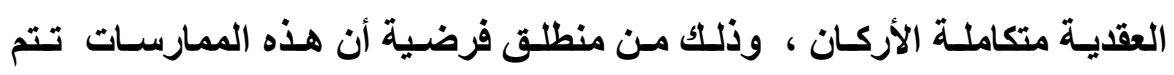
بصورة واسعة ومضطردة ، وينجم عنها أوجه عديدة من التجاوزات والإخلالات

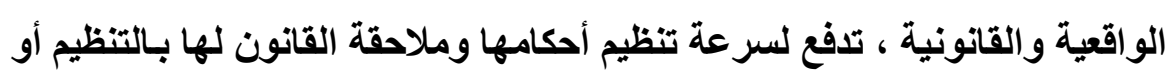
بالعقاب ، بوصفها من المستجدات التى أصبحت تفرض نفسها على الواقع العملى بقوة لا يحتمل الأمر معها التراخى فى تشريعها ، ومن ثم يلزم تحديد مسؤوليات

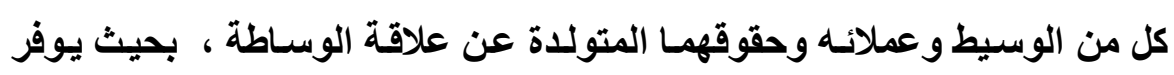

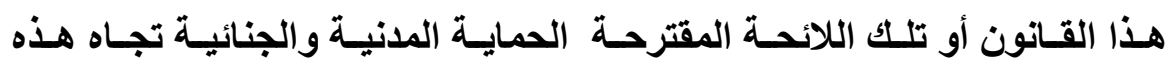
الممارسات المهنية الهامة. 


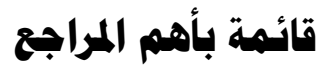

\section{أولاً: المراجع باللغة العربية.}

\section{ا- المراجع العاهة.}

ـ أحمد الرفاعي ، الحماية المدنية للمستهلك إزاء المضمون العقدي ، رسـالة دكتوراه

$$
\text { ، جامعة الزقازيق ، ( بدون تاريخ ) . }
$$

ـ أحمد فراج حسين ، أحكام الزواج في الشريعة الإسـلامية ، الدار الجامعية بيروت ،

$$
\text { - ค) } 9 \wedge \wedge
$$

- حسن كيره ، أصول قـانون العمل ، الطبعة الثالثة ، منشأة التعـارف ، الإسكندرية

$$
\text { . plava }
$$

- سميحه القليوبي ، شرح العقود التجارية ، دار النهضة العربية القاهرة 9 1 ام ـ - فوزي محمد سالم، شرح القانون التجاري ، الجزء الأول ، مكتبة دار الثقافة للنشر

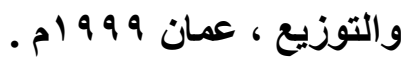
- سميحه القليوبي، شرح العقود التجارية ، القاهرة ، دار التهضة العربية ، 9^V ام. ـ ســير الـشرقاوي ، محاضـرات فـي العقـود التجاريـة والإفـلاس ، الطبعـة الأولـى

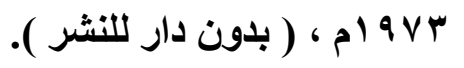
ـ سمير عبد السيد ، مصادر الالتزام ، الإسكندرية ، طبعة . .. ب م . - عبد الفتاح عبد الباقي ، نظرية العقد والإرادة المنفردة ، طبعة ؛ 91 ـ . ـ عبد الرزاق السنهوري ، الوسيط ، جV ، مجلا (1) ، طبعة بيروت بV ا ام. 
ـ عبد العزيز عـامر ، الأحوال الشخصية في الشريعة الإسـلامية ، دار الفكر العربي

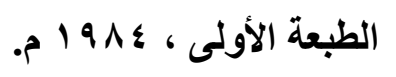

ـ عبد الفضيل محمد أحمد ، العقود التجارية وعمليات البنوك ، مكتبة الجلاء الجديدة

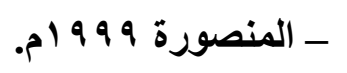

ـ عبد القادر حسين العطير ، الوسبط في شرح القـانون التجـاري ، الطبعة الثانيـة ،

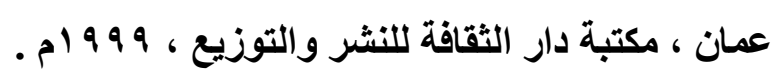

ـ عبد المنعم البدراوي ، النظريـة العامـة لالتزامـات ، الجزء الأول ، (بدون تـاريخ أو

$$
\text { دار للنشر). }
$$

ـ على البـارودي ، القـانون التجـاري ، العقود التجاريـة وعمليـات البنـوك ، منسشأة

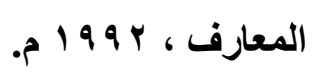

ـ على البارودي ، القانون التجاري اللبناني ، طبعة 9 ^ 1 م، ( بدون دار نشر ) . ـ كامل مرسي ، شرح القانون المدني الجديد ، العقود المسماة ، الطبعة الثانية. ـ محسن شفيق ، الوسيط في القانون التجاري ، جr ، ، طبعة 9ه 9 ام ، (بدون دار

$$
\text { (للنشر). }
$$

ـ محمــ أبـو زهـرة ، الأحسوال الشخـصية ، دارة الفكـر المسصري ، طبعـة ـ 190 محاضرات في عقد الزواج وأثثارها دار الفكر المصري ، (بدون تاريخ ودار نشر). ـ محمد حسين إسماعيل ، القانون التجاري ، الطبعة الأولى ، عمان ، مؤسسة الوراق

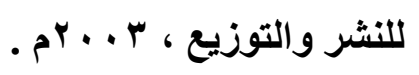


ـ محمد رأفت عثمان ، عقد الزواج ، أركانه وشروط صحته في الفقه الإسـلامي ، دار

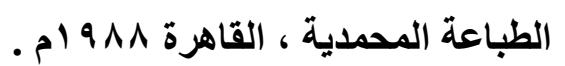

ـ محمد فوزي سـامي ، مبـادئ القـانون التجـاري ، عمـان ، منشورات مكتبية جامعة البلقان التطبيقية ، ب . . ب م. م.

ـ محمـود جمـال الـدين ذكي ، الـوجيز في نظريـة الالتزام ، جا، مسصادر الالتزام ،

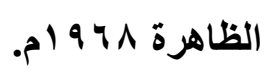

ـ محمـود نجيب حسني ، قانونيـة العقوبـات ، القسم الخـاص ، درا النهضة العربيـة (بدون تاريخ للنشر).

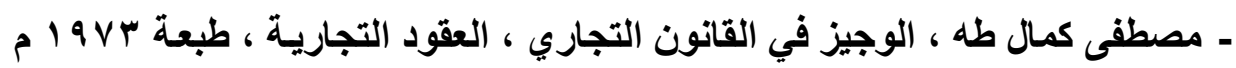

$$
\text { • (بدون دار للنشر ( }
$$

ـ هاني محمد دويدار ، النظام القانوني للتجـارة ، الطبعة الأولى ، المؤسسة الجامعية

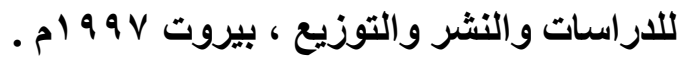

\section{r - r المراجع والأبماث المتخصصة.}

ـ أحمد عبد الكريم أبو شنب ، شروح قانون العمل الجديد ، مكتبة دار الثقافة ، عمـان $\cdot r^{r} \cdot r$

ـ أحمـد كامـل سـلامة ، الحمايـة المتبادلـة لأسـرار المهنـة ، دراسـة مقارنـة ، القـاهرة - 191 .

ـ أحمـد محمد سـعد ، نحو إرسـاء نظـام قـانوني لعقد المشورة المعلوماتيـة ، الطبعـة

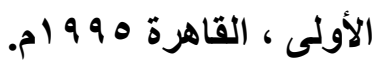


ـ نصير الجبوري ، الطبيعة القانونية لعقد البحث العلمي ، مجلة جامعة بابل للعلوم

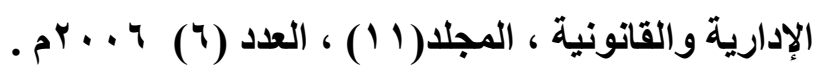

- جمال النكاس ، حماية المستهلك وأثرهـا على النظريـة العامـة في العقد في القانون المدني الكويتي ، مجلة الحقوق ، الإسكندرية .

- جمال النكاس ،العقود والاتفاقات الممهدة للتعاقد وأهمية التفرقة بين العقد والاتفاق

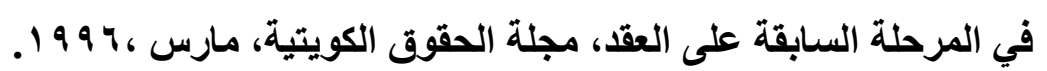
ـ حسام الاهـواني ، الحـق فـي احتـرام الحيــاة الخاصـة ، الحـق في الخصوصية دار

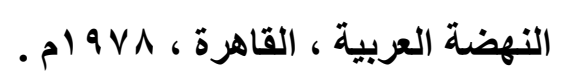

- حمدى محمود بارود ، القيمة القانونية للاتفاقات التى تتخلل مرحلة المفاوضـات قبل العقدية ، مجلة الجامعة الإسـلامية ،(سلسلة الدراسـات الإنسانية ) ، المجلـ الثالث

عشر العدد الثانى ، يونيو هـ ــ ب م .

- خالد جمال أحمد ، الالتزام بالإعلام قبل التعاقد ، دار النهضة العربية ، القاهرة( بلون

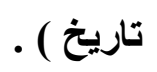

- رمضان جمال كامل ، مسئولية الأطباء والجراحين المدنية ، الطبعة الأولى ، المركز

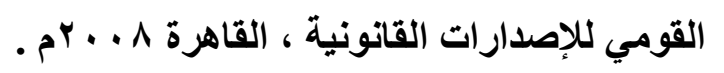

- زاهر طارق العبـادي ، الالتزام بـالإعلام في العقود الاككترونيـة ، دراسـة مقارنسة " رسالة ماجستير" ، الأردن( بدون تاريخ ).

ـ صبري محمد خـاطر ، الضمانات العقدية لنقل المعلومـات ، مجلة الحقوق ، جامعة

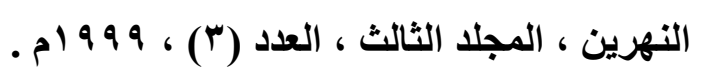


ـ طارق عبدالله أبو حَوَه ، خيار إنهاء العقد بإلارادة المنفردة ، مجلة البحوث القانونية

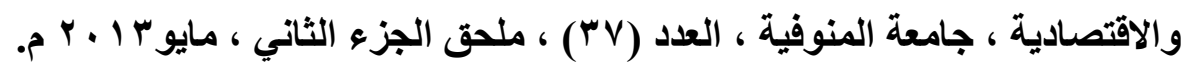
ـ عايد فايد عبد الفتاح فايد ، نشر صور ضحايا الجريمة ، دراسـة مقارنـة في القانون

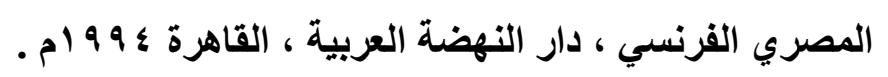

ـ عبد الرسـول عبد الرضـا ، الالتزام بضمان العيوب الحقيقيـة ، رسـالة دكتوراه ،

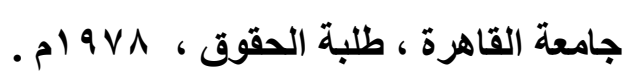

- عبد العزيز بن بـاز ، مجموع الفتـاوى ، جمع وترتيب د ـ محمد بن سـعد الشويعر إعداد وتنسيق موقع ابن باز ، باب المحرمات في النكاح ، الجزء الواحد والعشرون. ـ عبد العزيز سليم ، قضايا بالتعويضات ، الطبعة الثالثة ، المحلة الكبرى ، دار الكتب القانونية .) البدون تاريخ ) ـ طلبه وهبه خطاب ، المسئولية المدنية للمحامي : المحامي المفرد ـ المحامي في شركة محاماة مدنية ، الطبعة الأولى مكتبة سيد عبدالله وهبه القاهرة (بدون تاريخ). ـ عبد اللطيف الحسيني ، المسئولية المهنية عن الأخطاء المهنية ، الطبعة الأولى ،

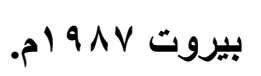

ـ عمر سالم محمد ، الطبيعة القانونية للمسؤولية السابقة على التعاقد ، (بدون دار أو

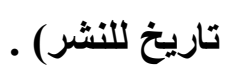

ـ فتحي المرصفاوي ، عقد العمل ، المكتبة الوطنيـة ، بنغازي ، ليبيـا ، (ردون تـاريخ • للنشر) 
ـ محسن شـفيق ، نقل التكنولوجيـا مـن الناحيـة القانونيـة ، مطبعـة جامعـة القـاهرة

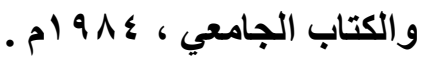

ـ محسن عبـد الحميـد البيـه ، إثبـات الزواج في القـانون المـصري، مجلـة البحـوث القانونية والاقتصادية ، جامعة المنصورة ، العدد رقم (V ع) أبريل • 1 • r م . ـ محسن عبد الحميد البيه ، الأحوال الشخصية لغير المسلمين ، مكتبة الجلاء الجديدة

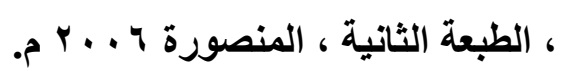

ـ محسن عبد الحميد البيه ، نظرة حديثه إلى خطأ الطبيب الموجب للمسئولية المدنية في ظل القواعد التقليدية ، مطبوعات جامعة الكويت ، الكويت ، ب 99 ام. 9 م.

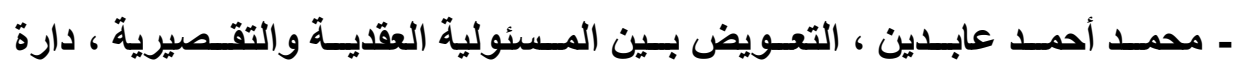
المطبوعات العلمية ، الإسكندرية ، (بدون تاريخ)

ـ محمـد حسن قاســم ، إثبـات الخطـأ فـي المجـال الطبـي ، دار الجامعـة الجديـدة ،

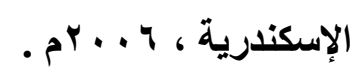

ـ محمد عبدالله حمود ، المسئولية التأديبية للمحامي في القانون الإماراتي والمقارن ،

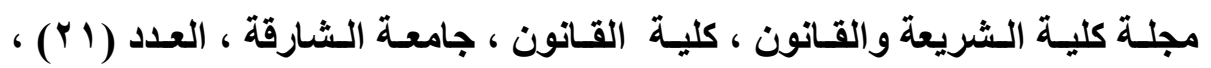

$$
\cdot \cos ^{r} \cdot \boldsymbol{\varepsilon}
$$

ـ محمد عزمي البكري ، مدونة الفقه والقضاء في قانون العمل الجديد الجزء الأول ،

$$
\text { الطبعة الثانية ، } 999 \text { ام (بدون دار للنشر ). }
$$

ـ محمـود صـالح جـابر ، على محمد أبو العز ، التكييف الفقهي لعقد العمل ، مجلـة

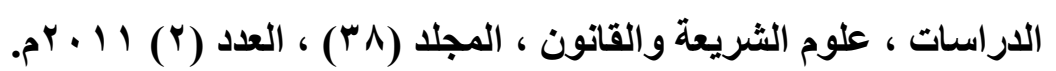


ـ مصطفى أحمد عبد الجواد ، الحياة الخاصة ومسئولية الصحفي ، دراسة مقارنـة من

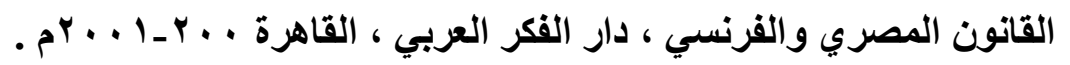

ـ هاني صلاح ، عقد نقل التكنولوجيا في قانون التجارة المصري الجديد ، دار النهضة

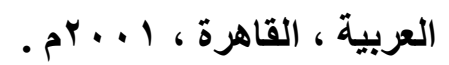
ثانياً: : هراجع باللغة الأجنبية :

- LAURENT AYNES, Principes de droit civil Français, tome 2 ,3éme édition, Bruxelles ,1978.

- JOSSERAND, Le problème de l'abus de droit ,DH 1967 , cite par J. CARBONNIER, Droit civil, tome 2 , La famille , les incapacités, Presses universitaires de Françe ,1983 .

- MICHEL PLANIOL, et G RIPERT, Traite pratique de droit civil français , 2éme édition, tome 2, L.G.D.J. 1952. 